\title{
पLBER
}

\author{
Redakcja: \\ Mirosława Huflejt-Łukasik \\ Agnieszka Pluta
}

\section{MECHANIZMY PSYCHOLOGICZNE I SPOŁECZNE WARUNKUJĄCE FORMUŁOWANIE OCEN ORAZ PODEJMOWANIE DZIAŁAŃ}

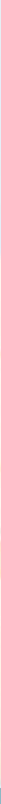

Tom 2 Serii wydawniczej Wydziału Psychologii Uniwersytetu Warszawskiego pt. Psychological Currents. Theory and Research. 

MECHANIZMY PSYCHOLOGICZNE I SPOŁECZNE WARUNKUJĄCE FORMUŁOWANIE OCEN ORAZ PODEJMOWANIE DZIAŁAŃ 



\section{Redakcja: \\ Mirosława Huflejt-Łukasik \\ Agnieszka Pluta}

\section{MECHANIZMY PSYCHOLOGICZNE I SPOŁECZNE WARUNKUJĄCE FORMUŁOWANIE OCEN \\ ORAZ PODEJMOWANIE DZIAŁAŃ}


Seria wydawnicza Wydziału Psychologii Uniwersytetu Warszawskiego

Psychological Currents. Theory and Research.

\section{Tom 2}

Mechanizmy psychologiczne i społeczne warunkujące formułowanie ocen oraz podejmowanie działań

Redakcja naukowa:

Mirosława Huflejt-Łukasik, Agnieszka Pluta

Recenzenci:

prof. dr hab. Roman Ossowski (Uniwersytet Kazimierza Wielkiego w Bydgoszczy) dr hab. Ludwika Wojciechowska, prof. UZ (Uniwersytet Zielonogórski)

Korekta językowa:

Małgorzata Najderska

Projekt okładki:

Dominika Karaś

Ilustracja na okładce:

https://www.shutterstock.com

Skład i łamanie:

Studio DTP Academicon | Patrycja Waleszczak

dtp@academicon.pl, dtp.academicon.pl

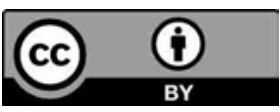

Publikacja jest udostępniona na licencji Creative Commons Uznanie autorstwa 4.0 Treść licencji jest dostępna na stronie: https://creativecommons.org/licenses/by/4.0/ Publikacja finansowana ze środków Wydziału Psychologii Uniwersytetu Warszawskiego przyznanych przez MNiSW w formie subwencji na utrzymanie i rozwój potencjału badawczego w roku 2021 (501-D125-01-1250000 zlec*5011000632).

Warszawa: Wydawnictwo Liberi Libri, 2021

www.LiberiLibri.pl

ISBN: 978-83-63487-55-3

DOI: $10.47943 /$ lib.9788363487553 


\section{SKRÓCONY SPIS TREŚCI}

Mirosława Huflejt-Łukasik, Agnieszka Pluta

Wstęp

MARIA LEDZIŃSKA

Nowe czasy, nowe źródła stresu, uniwersalne zasoby: związki między wybranymi

charakterystykami Ja a poczuciem stresu informacyjnego

Dorota Kobylińska, Zuzanna Molenda, Magdalena Śmieja, Maria Wasylkowska

Inteligencja emocjonalna a rozpiętość repertuaru strategii regulacji emocji

i ich efektywność

Kamilla Bargiel-Matusiewicz, Szymon Makuta, Krzysztof Szymanek, Krzysztof A. Wieczorek, Urszula Ziętalewicz, Ewa Pisula

Struktura i własności psychometryczne Skali optymizmu poznawczego - badania

pilotażowe

\section{CZĘŚĆ II. MECHANIZMY I SPOSOBY SAMOREGULACJI A PODEJMOWANIE DECYZJ}

I DZIAŁAŃ

Dorota RutKowsKa, Magdalena GrZESIK

Efekt sformułowania w decyzjach ryzykownych a ukierunkowania regulacyjne

Olga KęsKa, Kamilla Bargiel-Matusiewicz

Poziom aktywności fizycznej a cenione wartości i orientacja pozytywna

Anna Olejniczak-Serowiec, Dorota Rutkowska

Przyjmowanie perspektywy społecznej obniża, a obracanie mentalne podnosi poziom

wykonania zadania wymagającego przyjmowania perspektywy poznawczej 
Anna Nowak, Mirostawa Huflejt-Łukasik, Adrian Okoń

Coaching jako narzędzie rozwoju zawodowego i osobistego naukowców

CZĘŚĆ III. WYBRANE PROBLEMY KLINICZNE I SPOŁECZNE

Izabela Chojnicka

Umiejętności narracyjne osób w spektrum autyzmu

Ewa MalinowsKa

Neuropsychologiczna charakterystyka dynamiki zmian funkcji wykonawczych

u pacjentów po lekkich urazach czaszkowo-mózgowych okolic czołowych

Ksymena Pyl, Agnieszka E. Łyś, Kamilla Bargiel-Matusiewicz

Predyktory mitów na temat zgwałceń w męskich środowiskach sportowych na podstawie badania przeprowadzonego wśród zawodowych piłkarzy 


\section{SZCZEGÓłOWY SPIS TREŚCI}

Mirosława Huflejt-Łukasik, Agnieszka Pluta

Wstęp

MARIA LEDZIŃSKA

Nowe czasy, nowe źródła stresu, uniwersalne zasoby: związki między wybranymi

charakterystykami Ja a poczuciem stresu informacyjnego

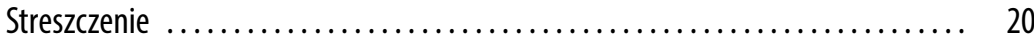

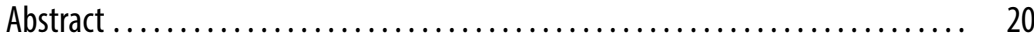

Jak powstaje stres informacyjny i od czego zależy jego siła? ............. 21

Ja jako ogniwo osobowości a natężenie stresu informacyjnego - przesłanki

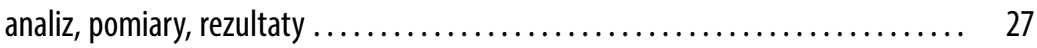

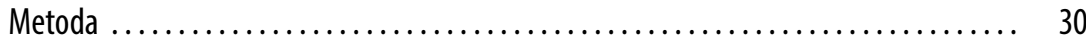

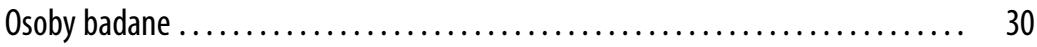

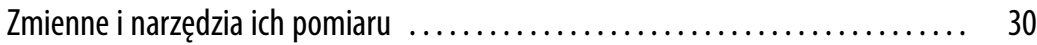

Poczucie stresu informacyjnego $\ldots \ldots \ldots \ldots \ldots \ldots \ldots \ldots \ldots \ldots \ldots \ldots \ldots . \quad 30$

Prężność psychiczna ....................................... 31

Stosunek do siebie i innych .................................. 31

Geneza standardów Ja ...................................... 31

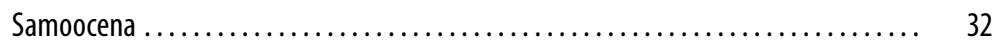

Rozbieżność Ja ........................................... 32

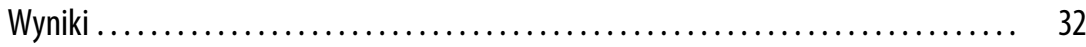

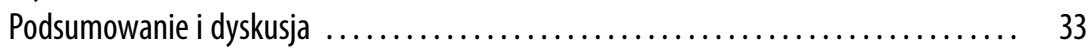

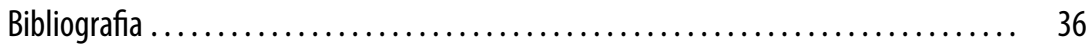

Dorota Kobylińska, Zuzanna Molenda, Magdalena Śmieja, Maria Wasylkowska

Inteligencja emocjonalna a rozpiętość repertuaru strategii regulacji emocji

i ich efektywność

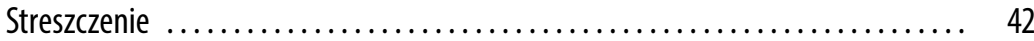




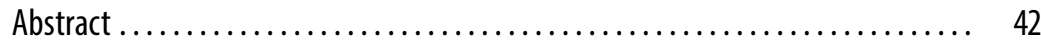

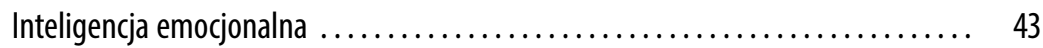

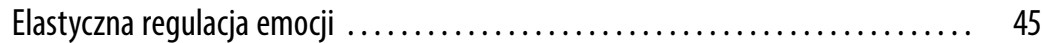

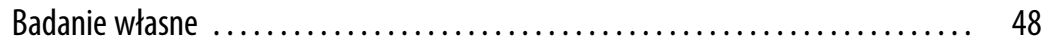

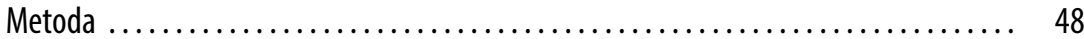

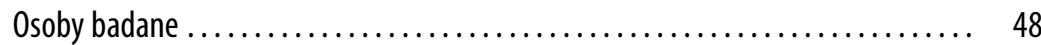

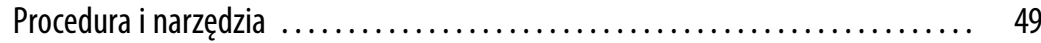

Procedura ............................................ 49

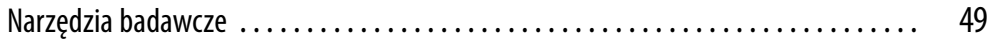

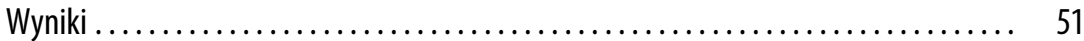

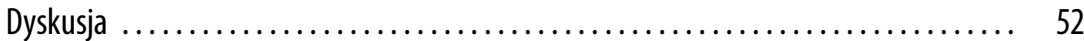

Bibliografía ............................................... 54

Kamilla Bargiel-Matusiewicz, Szymon Makuta, Krzysztof Szymanek, Krzysztof A. Wieczorek, Urszula Ziętalewicz, Ewa PIsUla

Struktura i własności psychometryczne Skali optymizmu poznawczego - badania pilotażowe ................................................ 59

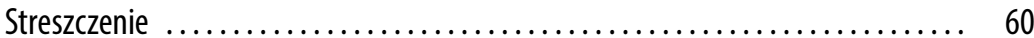

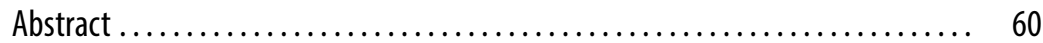

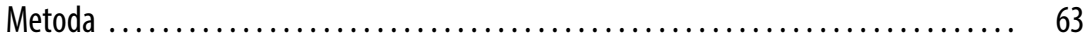

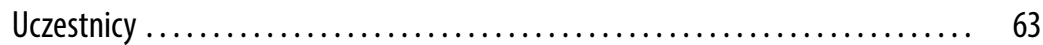

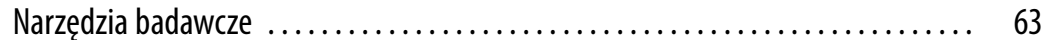

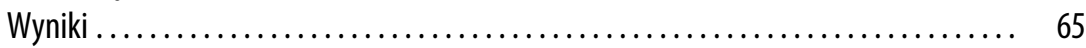

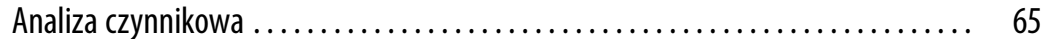

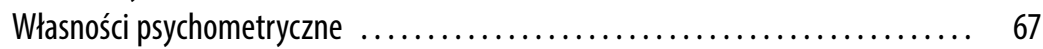

Korelacje między Skala optymizmu poznawczego a Kwestionariuszem mentalności spiskowej, Skala potrzeby poznawczego domknięcia oraz Trójwymiarową skalq prawicowego autorytaryzmu ................................ 67

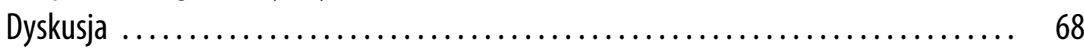

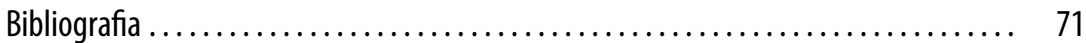

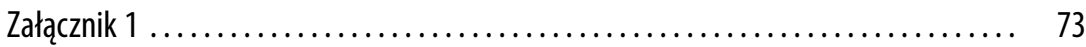

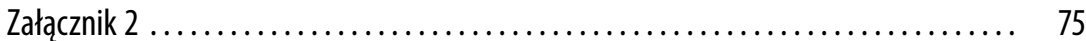

\section{CZĘŚĆ II. MECHANIZMY I SPOSOBY SAMOREGULACJI A PODEJMOWANIE DECYZJ}

Dorota RutKowska, Magdalena GrZESIK

Efekt sformułowania w decyzjach ryzykownych a ukierunkowania regulacyjne .. 
Abstract ................................................ 80

Efekt sformułowania w wyborach ryzykownych ................... 81

Promocyjne i prewencyjne ukierunkowania regulacyjne $\ldots \ldots \ldots \ldots \ldots \ldots \ldots . \quad 85$

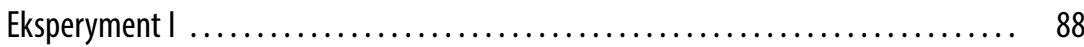

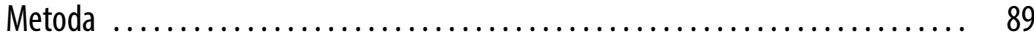

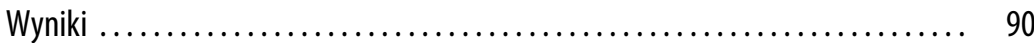

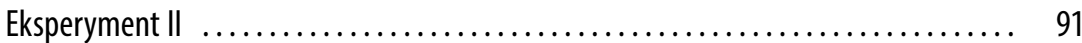

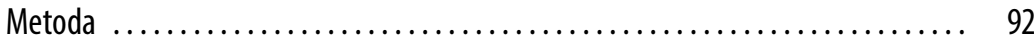

Wyniki ............................................. 93

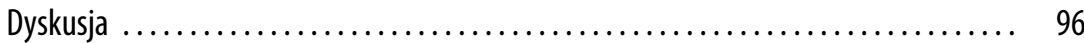

Bibliografia ............................................... 98

Olga Kęska, Kamilla Bargiel-Matusiewicz

Poziom aktywności fizycznej a cenione wartości i orientacja pozytywna ............ 101

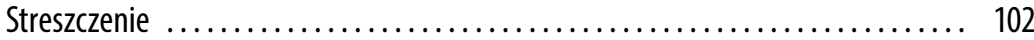

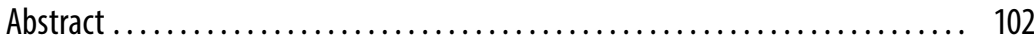

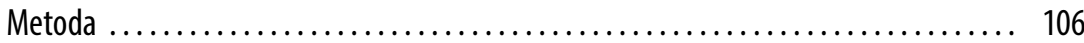

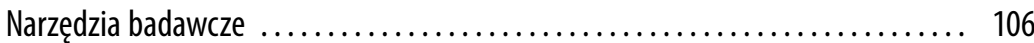

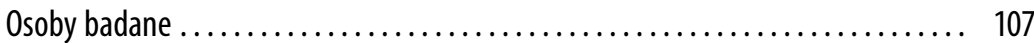

Wyniki ..................................................... 108

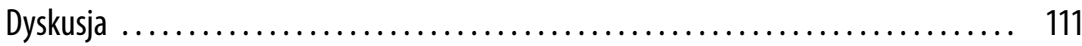

Bibliografia ............................................... 116

Anna Olejniczak-Serowiec, Dorota RutKowska

Przyjmowanie perspektywy społecznej obniża, a obracanie mentalne podnosi poziom wykonania zadania wymagającego przyjmowania perspektywy poznawczej .......... 121

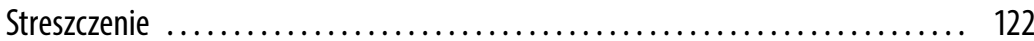

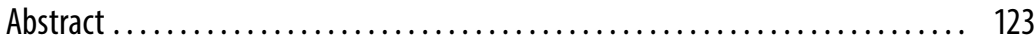

Metoda ................................................... 127

Osoby badane, schemat i procedura badania ....................... 127

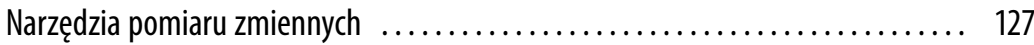

Wyniki ................................................ 131

Sytuacyjne wzbudzenie przyjmowania perspektywy a wykonanie zadania wymagającego poznawczego przyjmowania perspektywy:

weryfikacja hipotezy I . ...

Indywidualna skłonność do przyjmowania perspektywy społecznej

a wykonanie zadania wymagającego przyjmowania perspektywy poznawczej:

weryfikacja hipotezy lla 
Indywidualna skłonność do spontanicznego przyjmowania perspektywy społecznej a zdolność do obracania mentalnego: weryfikacja hipotezy IIb

Obracanie mentalne a wykonanie zadania wymagającego przyjmowania perspektywy poznawczej: weryfikacja hipotezy III

Obracanie mentalne i przyjmowanie perspektywy społecznej a wykonanie zadania wymagającego przyjmowania perspektywy poznawczej:

weryfikacja hipotezy IV

Podsumowanie . 133

Dyskusja 134

Bibliografia 136

Anna Nowak, Mirostawa Huflejt-Łukasik, Adrian Okoń

Coaching jako narzędzie rozwoju zawodowego i osobistego naukowców 139

Streszczenie 140

Abstract .... 140

Czym jest coaching? 142

Czym jest coaching w organizacji? 145

Realizacja coachingu w organizacji 147

Kiedy warto sięgnąć po coaching w organizacji? 149

Coaching z perspektywy nauki: dane z badań dotyczących efektywności coachingu 150

Nauka z perspektywy coachingu: specyfika pracy naukowców i wynikające z niej potencjalne obszary do pracy w coachingu ...

Zakończenie: czym może być coaching dla naukowców? ................ 155

Bibliografia

IZABELA ChOJNICKA

Umiejętności narracyjne osób w spektrum autyzmu

Streszczenie

Abstract

Komunikacja społeczna w przebiegu rozwoju typowego ................ 164

Komunikacja społeczna w ASD ............................. 165

Umiejętności pragmatyczne osób z ASD ......................... 166

Umiejętności narracyjne osób z ASD . ........................ 168

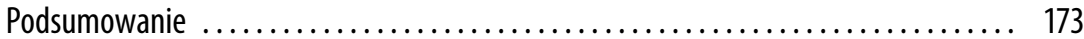

Bibliografia ............................................... 174 
Ewa MaLinowsKa

Neuropsychologiczna charakterystyka dynamiki zmian funkcji wykonawczych

u pacjentów po lekkich urazach czaszkowo-mózgowych okolic czołowych

Streszczenie ............................................. 180

Abstract ............................................... 181

Metoda ................................................ 186

Kryteria doboru osób badanych i ich charakterystyka ................ 186

Przebieg i organizacja badań .............................. 187

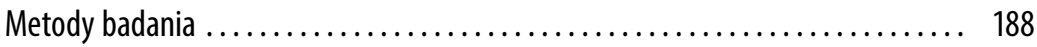

Schemat badania ........................................... 189

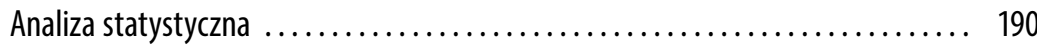

Wyniki ................................................. 190

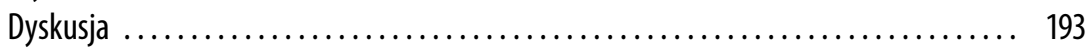

Bibliografía ................................................. 197

Ksymena Pyl, Agnieszka E. Łyś, Kamilla Bargiel-Matusiewicz

Predyktory mitów na temat zgwałceń w męskich środowiskach sportowych na podstawie badania przeprowadzonego wśród zawodowych piłkarzy .................. 203

Streszczenie .............................................. 204

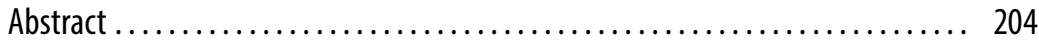

Sport jako czynnik kształtujący męskość tradycyjną ................. 205

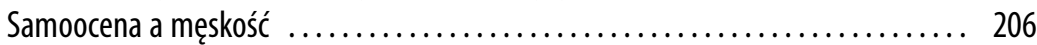

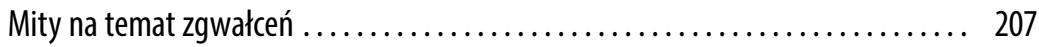

Mity na temat zgwałceń a płeć ofiary $\ldots \ldots \ldots \ldots \ldots \ldots \ldots \ldots . \ldots 209$

Mity na temat zgwałceń w środowiskach sportowców ............... 209

Metoda ............................................. 210

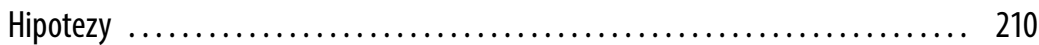

Rejestr zmiennych .................................... 211

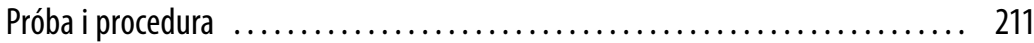

Materiały i narzędzia badawcze $\ldots \ldots \ldots \ldots \ldots \ldots \ldots \ldots \ldots \ldots \ldots \ldots \ldots . . \ldots 211$

Akceptacja mitów na temat zgwałceń $\ldots \ldots \ldots \ldots \ldots \ldots \ldots \ldots \ldots \ldots \ldots \ldots . \ldots \ldots$

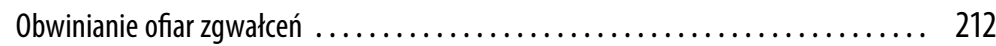

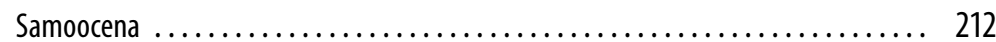

Identyfikacja z płcią męską ................................. 213

Dane demograficzne .................................. 213

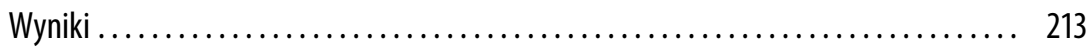

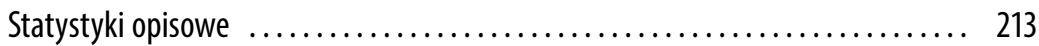

Przekonania na temat zgwałceń w grupie badanych piłkarzy ............ 214 
Obwinianie ofiary a wiek, poziom wykształcenia i wielkość miejsca pochodzenia ... 216

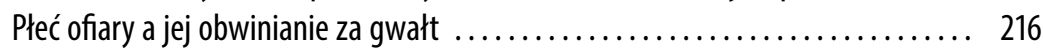

Związek obwiniania ofiary z przekonaniami na temat gwałtu .............. 217

Postawa wobec gwałtu a samoocena i identyfikacja z płcią męską .......... 217

Dyskusja ................................................ 218

Ograniczenia badania i przyszłe kierunki badań .................... 220

Bibliografia ............................................. 220 


\section{Wstęp}

Oddajemy w ręce czytelników kolejny, II tom serii wydawniczej Wydziału Psychologii Uniwersytetu Warszawskiego Psychological Currents - Theory and Research, zatytułowany Mechanizmy psychologiczne i społeczne warunkujące formułowanie ocen oraz podejmowanie działań. W ramach serii wydawniczej Wydziału Psychologii Uniwersytetu Warszawskiego prezentujemy Państwu najnowszą i różnorodną wiedzę psychologiczną przede wszystkim w postaci rezultatów przeprowadzonych badań, ale też tekstów przeglądowych, teoretycznych. To, co łączy kolejne tomy serii, to szeroka perspektywa samoregulacji jako jednego z podstawowych paradygmatów w psychologii. Dlatego zarówno część I, jak i II aktualnego tomu dotyczą wprost tematów z obszaru samoregulacji, a III część wybranych problemów klinicznych i społecznych.

Część I tomu - zatytułowana Psychologiczne mechanizmy regulacji $i$ ich uwarunkowania - zawiera teksty odnoszące się do mechanizmów psychologicznych ściśle powiązanych z samoregulacją. Otwierający tę część tekst Marii Ledzińskiej prezentuje rezultaty i wnioski zebrane $\mathrm{w}$ ramach badań dotyczących roli Ja w radzeniu sobie z poczuciem stresu informacyjnego. Ja opisane jest jako zasób samoregulacji pozwalający eksplorować otoczenie, a jednocześnie potencjalnie efektywniej selekcjonować pozyskiwane dane w codziennym przepełnionym nimi środowisku. Z kolei tekst Doroty Kobylińskiej i współautorek dotyczy elastyczności regulacji emocji i znaczenia inteligencji emocjonalnej dla wyboru stosowanych strategii regulacji emocji. Optymizm, w tym optymizm poznawczy, to kolejna podstawowa dla możliwości samoregulacji osoby zmienna. Zespół badawczy pod kierunkiem Kamilli Bargiel-Matusiewicz przedstawia w swoim artykule wyniki badania pilotażowego dotyczącego własności psychometrycznych Skali optymizmu poznawczego. To nowe narzędzie służy do pomiaru zaufania w możliwości poznawcze ludzi w ogóle, reprezentowane zaufaniem do wiedzy naukowej, rezultatów badań. Mierzy też indywidualny optymizm poznawczy, czyli na 
ile osoba jest przekonana o posiadaniu przez siebie zdolności samodzielnego, logicznego i niezawodnego myślenia. Ten tekst zamyka pierwszą część książki.

II część tomu poświęcona jest temu, jak mechanizmy i sposoby samoregulacji, przekładają się na konkretne decyzje czy działania. Tę część otwiera tekst Doroty Rutkowskiej i Magdaleny Grzesik opisujący eksperymenty dotyczące wpływu na podejmowane decyzje ukierunkowania regulacyjnego, czyli tendencji motywacyjnej - dążenia bądź do maksymalnego pozytywnego efektu działań czy decyzji, bądź minimalnego - skupionego na niedopuszczeniu do stanu negatywnego. Tendencja do zwracania uwagi na pozytywne aspekty własnego życia i samego siebie, nazywana orientacją pozytywną, była wraz z wartościami przedmiotem badań Olgi Kęski i Kamilli Bargiel-Matusiewicz. Autorki opisują w kolejnym tekście, która $\mathrm{z}$ tych psychologicznych zmiennych wiązała się z różnicami dotyczącymi poziomu aktywności fizycznej u osób, a także ich zaangażowania w kontrolę masy ciała i żywieniowych nawyków. Szósty rozdział autorstwa Anny Olejniczak-Serowiec i Doroty Rutkowskiej dotyczy czynników wpływających na poziom wykonania zadania wymagającego przyjmowania innej perspektywy poznawczej. W opisanych eksperymentach uwzględniono przyjmowanie perspektywy społecznej, innych osób oraz zdolność do obracania mentalnego. II część tomu zamyka rozdział dotyczący coachingu jako metody psychologicznej umożliwiającej rozwój osobisty i zawodowy, a będącej jednocześnie sposobem i okazją do uruchomienia indywidualnych procesów samoregulacji. Tekst przedstawia coaching jako metodę ogólnie, choć koncentruje się na potencjalnym wykorzystaniu tej metody w grupie zawodowej, jaką są naukowcy.

Część III tomu dotyczy wybranych problemów klinicznych i społecznych. Rozpoczyna ją rozdział teoretyczny napisany przez Izabelę Chojnicką dotyczący kompetencji narracyjnych osób z zaburzeniem ze spektrum autyzmu. Autorka opisała, jakich trudności w zakresie dyskursu narracyjnego mogą doświadczać osoby ze spektrum autyzmu oraz jaki jest potencjalny mechanizm tych deficytów. Odniosła się także do różnic płciowych w odniesieniu do kompetencji narracyjnej. Drugi tekst w tej części, autorstwa Ewy Malinowskiej, poświęcony jest dynamice zmian w zakresie funkcji wykonawczych u pacjentów po urazach czaszkowo-mózgowych. Autorka przedstawiła wyniki badań neuropsychologicznych przeprowadzonych $\mathrm{w}$ grupie pacjentów po urazach okolic czołowych oraz w grupie osób bez urazów mózgu. Szczegółowo opisała, które wymiary funkcji wykonawczych różnicują pacjentów i grupę kontrolną. Odniosła się także do czynników wpływających na głębokość zaburzeń 
oraz ich wycofywanie się. W ostatnim tekście tomu autorki - Ksymena Pyl, Agnieszka Łyś oraz Kamilla Bargiel-Matusiewicz - zaprezentowały wyniki badań dotyczących czynników wpływających na akceptację mitów na temat zgwałceń wśród zawodowych piłkarzy. Badanie wykazało, że akceptacja mitów na temat zgwałceń, mimo dużego zróżnicowania, jest spójna z funkcjonowaniem przekonania „ofiara kłamała”.

Książka jest zbiorem, który porusza wątki zarówno z zakresu psychologii poznawczej, emocji, psychologii społecznej czy w końcu klinicznej. Jak wskazali recenzenci tomu, stanowi on „istotne dopełnienie stanu wiedzy psychologicznej umożliwiający prowadzenie rozważań nad regulacyjną rolą zachowania" oraz „może być wzorem do tworzenia projektów badawczych” (z recenzji prof. Romana Ossowskiego). „Pokazuje nowe sposoby myślenia o problemach i ich poznawaniu. Może też pełnić rolę stymulującą dla przyszłych badaczy oraz prowokować do refleksji i krytycznego spojrzenia na zasoby dotychczas zgromadzonej wiedzy. Może także ukierunkować obserwację otaczającej rzeczywistości oraz inspirować pomysły na praktyczny sens prowadzonych badań" (z recenzji prof. Ludwiki Wojciechowskiej).

Książka zawiera treści interesujące dla psychologów-badaczy, studentów psychologii, a także ma potencjał, by inspirować praktykę, która korzysta $\mathrm{z}$ wiedzy psychologii jako nauki.

Redaktorki zbioru: Mirosława Huflejt-Łukasik i Agnieszka Pluta

Sposób cytowania: Huflejt-Łukasik, M., Pluta, A. (2021). Wstęp. W: M. Huflejt-Łukasik, A. Pluta (red.), Mechanizmy psychologiczne i społeczne warunkujace formułowanie ocen oraz podejmowanie działań (s. 13-15). Warszawa: Wydawnictwo Liberi Libri. https://doi.org/10.47943/lib.9788363487553.rozdzial00 

CZĘŚĆ I. PSYCHOLOGICZNE MECHANIZMY REGULACJI I ICH UWARUNKOWANIA 

MARIA LEDZIŃSKA (iD) https://orcid.org/0000-0003-1961-550X

Wydział Psychologii, Uniwersytet Warszawski

Nowe czasy, nowe źródła stresu, uniwersalne zasoby: związki między wybranymi charakterystykami Ja a poczuciem stresu informacyjnego

New times, new sources of stress, but universal resources: Relationships between selected characteristics of psychological self and the experience of information stress

Sposób cytowania: Ledzińska, M. (2021). Nowe czasy, nowe źródła stresu, uniwersalne zasoby: związki między wybranymi charakterystykami Ja a poczuciem stresu informacyjnego. W: M. Huflejt-Łukasik, A. Pluta (red.), Mechanizmy psychologiczne i społeczne warunkujace formułowanie ocen oraz podejmowanie działań (s. 19-40). Warszawa: Wydawnictwo Liberi Libri. https://doi.org/10.47943/lib.9788363487553. rozdzial01

Przygotowano w ramach programu badań finansowanych na Wydziale Psychologii UW w 2019 roku. 


\section{Streszczenie}

Autorka charakteryzuje zwięźle stres informacyjny. Koncentruje uwagę na wybranych podmiotowych wyznacznikach siły jego doznań, traktując je jako zasoby. Przywołuje wyniki ostatnich pięciu badań nad związkiem między różnymi charakterystykami Ja a poczuciem stresu informacyjnego. Informują one, że takie aspekty Ja jak: rezyliencja, wysoka samoocena, pozytywny stosunek do siebie i innych oraz niezależność standardów, korelują ujemnie z dyskomfortem psychicznym towarzyszącym egzystencji w środowisku bogatym w informacje. Natomiast związki między niespójnością Ja a doznawanym stresem są dodatnie. W Dyskusji zwraca uwagę, że pozytywne aspekty Ja ułatwiają eksplorację otoczenia i refleksyjną ocenę pozyskiwanych informacji, co może przekładać się na bardziej efektywną selekcję.

Słowa kluczowe: stres psychologiczny, stres informacyjny, technologia informacyjna, zasoby, charakterystyki Ja

\section{Abstract}

The Author briefly characterizes information stress. She focuses on a few selected, individual differences parameters as determinants of its strength, treating those characteristics as resources. The results of five recent studies into the relationships between various individual characteristics and infostress. The results of those studies suggest that characteristics such as: resilience, high self-esteem, positive outlook on self and others and independence of standards, all correlate negatively with psychological distress resulting from loving in an information-rich environment. On the other hand, the correlation between inconsistencies in self and infostress are positive. The conclusion drawn in that positive aspects of self ease the exploration of environment and the processing of acquired information (through reflection), which may in turn make selection of information easier. 
Keywords: psychological stress, information stress, information technology, resources, characteristics of self

\author{
„Poznaj siebie \\ Szanuj siebie \\ Bądź sobą \\ Władaj sobą"
}

Sentencje delfickie (oprac. Bielawski, 2018)

\title{
Jak powstaje stres informacyjny i od czego zależy jego siła?
}

Problematyką stresu informacyjnego zajmuję się od dwóch dekad, licząc od daty opublikowania pierwszego tekstu (Ledzińska, 2001). Ujmuję różne aspekty tego zjawiska i dlatego realizowane studia mają potrójne zakotwiczenie teoretyczne. Jako nauczyciel akademicki odwołuję się do stwierdzeń z zakresu psychologii nauczania (Ledzińska, Czerniawska, 2011; Littleton, Wood, Kleine Staarman, 2010). Jako badacz korzystam z dorobku psychologii różnicowej, koncentrując uwagę na znaczeniu różnic indywidualnych w funkcjonowaniu poznawczym (Ledzińska, Zajenkowski, Stolarski, 2013). Jako aktywny uczestnik życia społecznego podejmuję refleksję nad przemianami dokonującymi się w skali ziemskiego globu, wynikającymi z rozwoju technologii informacyjnej (Ledzińska, 2012). I choć zmiany te zachodzą we wszystkich dziedzinach życia i są ze sobą powiązane, to w każdej $\mathrm{z}$ nich mają swoją specyfikę. To $\mathrm{z}$ tego powodu $\mathrm{w}$ badaniach naukowych dokonuje się zawężenia pola analiz, poznając zjawiska w ramach tzw. strumieni (ścieżek, nurtów) globalizacji. Psychologa interesują w sposób szczególny te mieszczące się w nurcie informacyjnym oraz kulturowym. Związane są one $\mathrm{z}$ obiegiem i wymianą informacji, idei, wiedzy, sposobów myślenia, przekonań, wartości, czyli dóbr niematerialnych.

Przedmiotem studiów czyni się wiele aspektów globalizacji, a jednym z nich są skutki przemian ogólnoświatowych (Stiglitz, 2004). Wielu badaczy zwraca uwagę na złożony charakter tych następstw. McLuhan i McLuhan 
(1992) uczynili to, formułując tzw. „prawa mediów”. Autorzy uporządkowali problemy wywołane obecnością w codziennym życiu nowoczesnej techniki, nadając im postać czteropolowego zestawienia. Dwa pierwsze prawa uwypuklają zjawiska pozytywne, a dwa następne - negatywne.

Oto następstwa pozytywne:

- prawo wzmocnienia: każdy wytwór człowieka wzmacnia jego zdolności bądź przyspiesza pewne procesy (enhancement),

- prawo odzyskania: dzięki nowym wytworom zjawisko uchodzące za przestarzałe ponownie zyskuje na znaczeniu (retrieval).

Z kolei skutki negatywne ilustrują:

- prawo osłabienia: rozwój techniki sprawia, że pewne rozwiązania uznawane są za przestarzałe, a nawet eliminowane (obsolescence),

- prawo odwrócenia: $\mathrm{w}$ szczy towym momencie rozwoju techniki rozpoczyna się specyficzny proces polegający na tym, że wraz z osiągnięciem granic rozwoju każde zjawisko przekształca się w swe przeciwieństwo, zapoczątkowując procesy degradacji (reversal).

Stres informacyjny traktuję jako jeden z wielu przykładów efektu odwrócenia. Jak pisał przed laty Paul Levinson (1999), nowoczesna technika ma miękkie ostrze, którym „rani” niepostrzeżenie osoby niedoceniające siły jej oddziaływania. Przyczyną tego faktu pozostają nie same urządzenia, ale sposób korzystania z nich, pozbawiony nierzadko znamion racjonalności (Targowski, 2015).

Stres informacyjny definiuję jako subiektywny dyskomfort odczuwany przez wielu współczesnych żyjących w środowisku bogatym w informacje (Ledzińska, w: Heszen, 2013). Powstaje w następstwie zakłócenia podstawowej zasady życia, jaką stanowi wymiana - między człowiekiem i otoczeniem - energii, materii oraz informacji. Nazwano ją przed laty metabolizmem energetyczno-informacyjnym (Kępiński, 2003). Podstawową formę wymiany informacyjnej stanowi przetwarzanie danych, czyli operacje przekształcające informację wejściową w wyjściową. Jednym $\mathrm{z}$ ważnych ogniw świadomego przetwarzania jest selekcja, wybór informacji odbieranych z zewnątrz oraz wytwarzanych przez człowieka w toku aktywności pamięciowej, myślowej i wyobrażeniowej.

Wymiana informacyjna ulega niejednokrotnie poważnemu zakłóceniu, co znajduje odzwierciedlenie w subiektywnym doświadczeniu. Główne przyczyny zaburzenia tej wymiany są następstwem następujących faktów: 
- postęp technologiczny „wyprzedził ewolucję; mózg ludzki jest dziś mechanizmem transmisji sygnałów milion razy wolniejszym w porównaniu z nowoczesnym komputerem (Morbitzer, 2007);

- dominacja techniki przyczyniła się do zmian w kulturze rozumianej jako dominujące wzorce myślenia i zachowania (Ledzińska, 2017; Straś-Romanowska, 2016; Targowski, 2015). Oto niektóre przykłady: pośpiech, dłuższa oraz intensywniejsza koncentracja na pobieraniu informacji w porównaniu z przetwarzaniem, pogoń za nowością nazwana przez Shenka (1997) strategią „,strusia pędziwiatra” (efekt traktowania informacji jako nadwartości), gromadzenie materiałów bez ich uważnej i niespiesznej lektury, określane jako „ksero kultura” (Eco, 2007);

- stały, lawinowy przyrost informacji i wiedzy - technologia informacyjna ułatwia wyszukiwanie informacji, ich gromadzenie, przetwarzanie, przesyłanie na odległość, wykorzystywanie. Nade wszystko jednak ułatwia wytwarzanie treści oraz ich upowszechnianie (Morbitzer, 2007). $\mathrm{W}$ rezultacie mamy do czynienia $\mathrm{z}$ - niemającą swego odpowiednika w przeszłości - dysproporcją między informacją oraz wiedzą ujmowaną w wymiarze ilościowym a możliwościami ich przyswojenia. Skalę tego przyrostu - z uwzględnieniem przeszłej i teraźniejszej perspektywy - oraz kwestie jakości treści przedstawiłam wyczerpująco we wcześniejszych publikacjach, m.in. w rozdziale opublikowanym w pierwszym tomie niniejszej serii (Ledzińska, 2020).

Należy pamiętać, że dysproporcja między dostępnymi treściami i możliwościami ich przetworzenia przez ludzki umysł stanowi zjawisko ponadczasowe. Dziś jest ono szczególnie mocno odczuwane ze względu na ów rozziew, wielką dysproporcję między łatwym dostępem do ogromnych oraz stale rosnących zasobów informacji oraz wiedzy a możliwością ich przetworzenia, a zwłaszcza zbudowania w oparciu o nie wiedzy jednostkowej. Pisali o tym zjawisku przedstawiciele różnych dyscyplin, proponując dlań różne nazwy. Oto one: technostres (Shenk, 1997), overload (Bawden, Robinson, 2009; Eppler, Mengis, 2004; Levine, 2017; Matthews, Campbell, 2009), library anxiety (Mellon, 1986), information anxiety (Girard, Allison, 2008; Wurman, 1987), horror informaticus (Straś-Romanowska, 2016).

Żaden $\mathrm{z}$ proponowanych terminów nie oddawał złożonego charakteru zjawiska i nie ujmował go w sposób całościowy. Subiektywny dyskomfort psychiczny wykracza bowiem poza doświadczenie przeciążenia (przeładowa- 
nia, zmęczenia) umysłu. Dotyka, jak każdy stres, całego człowieka, jego ciała i psychiki (Heszen, 2013; Łosiak, 2008). Patrząc z medycznego punktu widzenia, powiemy, że powstaje w sytuacji zaburzenia przebiegu metabolizmu energetyczno-informacyjnego (Kępiński, 2003). Psycholog wiąże stres informacyjny $\mathrm{z}$ deprywacją potrzeby orientacyjnej, stanowiącej jedną $\mathrm{z}$ odmian potrzeby poznawczej (Cacioppo, Petty, 1982; Petty, See, 2007). Bywa, że - w obliczu wielu danych - nie wiemy, która informacja jest ważna, wiarygodna, przydatna, użyteczna. Wybieranie treści - jeśli nie jest przypadkowe - wymaga sformułowania celu poszukiwań oraz dysponowania kryteriami selekcji. Dostarczają ich m.in. wiedza, indywidualne doświadczenie i system wartości, powstające stopniowo w ontogenezie. Opisywany dyskomfort (dystres) powstaje ponadto na wszystkich etapach przetwarzania informacji: towarzyszy ich odbiorowi, obróbce, przypominaniu i wykorzystywaniu. W jego powstawaniu ważną rolę odgrywa sfera afektywna, gdyż wymiana informacyjna sprzężona jest z emocjami. Negatywnej entropii, czyli porządkowaniu informacji, towarzyszą pozytywne emocje. Natomiast nieporządek, chaos, brak możliwości scalenia zbyt licznych danych, wywołuje stan rozdrażnienia, niepokoju (Kępiński, 2003).

Naturalnym rozwiązaniem koncepcyjnym pozostało odwołanie się do wiodących ujęć stresu, czyli poznawczej koncepcji autorstwa Lazarusa i Folkman (1984) oraz teorii zasobów Hobfolla (2006). Główne tezy pierwszego ujęcia brzmią następująco (Lazarus, Folkman, 1987):

- człowiek pozostaje w stałej interakcji ze światem, a wymiana ta jest dynamiczna, czyli zmienna w czasie i ma charakter transakcji;

- transakcja może być: nieistotna, sprzyjająco-pozytywna lub stresująca; ta ostatnia bywa interpretowana w kategoriach krzywdy/straty, zagrożenia lub wyzwania;

- realizacji celów towarzyszy ocena poznawcza zachodzących zdarzeń, wpływająca na podejmowane sposoby radzenia sobie;

- oceny poznawcze definiowane są jako procesy wartościowania;

- te pierwotne wiążą się $\mathrm{z}$ odpowiedzią na pytanie: co oznacza to dla mnie konkretne wydarzenie, wtórne - co mogę z tym zrobić;

- stres rejestrowany w subiektywnym doświadczeniu powstaje wtedy, gdy problem postrzegany jest jako przekraczający możliwości radzenia sobie ze względu na posiadane zasoby.

Oryginalną koncepcję zasobów COR (conservation of resources theory) zaproponował przed laty Hobfoll (2006). Specyfiką ujęcia badacza pozostaje przede 
wszystkim uwypuklenie, po pierwsze, społecznego kontekstu powstawania stresu, po drugie - faktu dążenia do pozyskania, utrzymania oraz chronienia tego, co człowiek uważa za cenne. Ochrona zasobów stanowi podstawową motywację człowieka, a ich faktyczna utrata lub zagrożenie rodzi stres. Autor wyodrębnił następujące ich rodzaje: zasoby materialne (np. cenne przedmioty), zasoby podmiotowe (kompetencje, umiejętności, cechy osobowości), zasoby stanu (posada w pracy, rodzina, zdrowie) i zasoby energii.

Stres informacyjny traktuję jako odmianę stresu cywilizacyjnego. Kryterium wyodrębnienia nowej jego odmiany stanowi specyfika stresora, czyli źródła stresu. Stanowią je informacje, ujmowane w proponowanym przeze mnie ujęciu w wymiarze ilościowym, i odnoszone do indywidualnych zasobów poznawczych. Barierę ze strony umysłu stanowią funkcjonalne właściwości uwagi i pamięci (Nęcka, Orzechowski, Szymura, 2006). Badania nad tak zdefiniowanym zjawiskiem prowadzę samodzielnie oraz we współpracy $\mathrm{z}$ magistrantami i doktorantami. Poprzedzały je poniższe założenia.

- Intensywność siły doznań stresu (inaczej poczucie stresu), jak każdą jego odmianę, można mierzyć introspekcyjnie, traktując jako uogólnione, jednostkowe doświadczenie (Plopa, Makarowski, 2010). Nie jest to zatem jedynie pomiar tak zwanego stanu stresu (Strelau, 2014). Ten ostatni zdefiniowano we wcześniejszych, zwłaszcza biologicznie zorientowanych, studiach jako zespół silnych emocji negatywnych i innych stanów emocjonalnych wywołujących dystres oraz sprzężonych z nimi zmian fizjologicznych oraz biochemicznych, przekraczających tzw. optymalny poziom aktywacji.

- Siła subiektywnych doznań stresu pozostaje w związku z indywidualnymi zasobami, czyli psychologiczną sylwetką jednostki. Ujmuję je w sposób całościowy, biorąc pod uwagę następujące ogniwa:

- Obcowanie na co dzień z dużymi porcjami szybko emitowanych informacji stanowi obciążenie dla systemu poznawczego, zwłaszcza dla uwagi i pamięci. W efekcie następuje osłabienie lub utrata kontroli.

- Korelatem siły doznań stresu informacyjnego pozostaje - stanowiący fundament osobowości - temperament jednostki, uczestniczący $\mathrm{w}$ regulowaniu optymalnego poziomu aktywacji oraz moderujący reakcje emocjonalne. Zaliczono go do znaczących zasobów, przewidując, że opisane w literaturze zależności ogólne - ujmujące relację temperament-stres, odnoszą się także do wyodrębnionej przeze mnie jego odmiany. 
- Stres informacyjny doświadczany jest z różną intensywnością. O natężeniu siły jego doznań decyduje konfiguracja wyróżników funkcjonowania poznawczego, metapoznawczego i emocjonalno-społecznego. Istotną rolę odgrywa też wspomniany już temperament stanowiący energetyczne zaplecze umysłu, wraz z jego nadbudową, czyli osobowością.

Zrealizowane badania miały podobny schemat. $\mathrm{W}$ pakiecie narzędzi znajdował się każdorazowo autorski kwestionariusz do diagnozy siły doznań stresu informacyjnego oraz standardowa technika, tj. kwestionariusz i/lub test do pomiaru wybranych aspektów psychiki. Respondentami byli młodzi dorośli - osoby między 18. a 35. rokiem życia, ze względu na ich największą ekspozycję na stres informacyjny. Związek między wiekiem badanych a siłą stresu informacyjnego był przedmiotem oddzielnych studiów (Wiśniewska, Ledzińska, 2020). W niniejszym tekście przywołuję jedynie wybrane stwierdzenia, eksponując główne wzorce zależności (m.in. Ledzińska, 2009, 2012; Ledzińska, Postek, 2017; Oniszczenko, Ledzińska, 2019; Postek, Ledzińska, 2015). Oto najważniejsze $\mathrm{z}$ nich.

1. Nie ma związku między inteligencją poznawczą a siłą doznań stresu informacyjnego. Stres ten korelował natomiast ze sposobem przetwarzania informacji. W sferze funkcjonowania poznawczego podmiotowym korelatem poczucia stresu okazała się niska odporność na interferencję, która nasila stres (w przeciwieństwie do uważności) oraz charakterystyczny sposób obróbki danych ujmowany na wymiarach stylów poznawczych: analityczny (przeciwieństwo syntetycznego) i konkretny (przeciwieństwo abstrakcyjnego).

2. W obszarze funkcjonowania metapoznawczego silniejszy stres wiązał się z obecnością tzw. dysfunkcjonalnych przekonań metakognitywnych oraz deficytami w zakresie samokontroli. Wyodrębnione zostały trzy jej wzorce, tj. kontrola słaba, sztywna i chwiejna.

3. Negatywnej emocjonalności (m.in. lęk, reaktywność emocjonalna), trudnościom $\mathrm{w}$ regulowaniu emocji, preferowaniu strategii tłumienia emocji, niższej inteligencji emocjonalnej towarzyszyły silniejsze doznania stresowe. Stwierdzono je ponadto u osób z wyższymi wynikami na skali spektrum autyzmu oraz depresji.

4. Osoby z wyższymi kompetencjami społecznymi oraz otrzymujące wsparcie społeczne doświadczają słabszego stresu. 
5. Temperament - diagnozowany w ramach różnych koncepcji teoretycznych, w obszarze których powstały dostępne techniki diagnozy - okazał się znaczącym korelatem stresu. Główny jego wymiar - w przypadku diagnozy postulowanej przez Regulacyjną Teorię Temperamentu stanowią małe możliwości przetwarzania stymulacji, czyli wysoka reaktywność, perseweratywność oraz niska wytrzymałość, nasilające doznania stresu. Silniejszy stres wiązał się ponadto z neurotycznością i nieadaptacyjnym perfekcjonizmem, słabszy z kolei z wyraźniejszą hierarchią wartości, silniejszym poczuciem sensowności, zrozumiałości oraz zaradności. Ostatnie z przytoczonych rezultatów stanowiły inspirację do realizacji programu badań uwzględniających specyfikę Ja jako podmiotowego korelatu intensywności doznań stresu informacyjnego.

\section{Ja jako ogniwo osobowości a natężenie stresu informacyjnego - przesłanki analiz, pomiary, rezultaty}

Autorzy koncepcji osobowości ujmowanej jako system wyodrębniają w niej niższe i wyższe poziomy regulacji zachowania. Każdy z nich może generować wewnętrzne napięcia. Te wzbudzane na niższym poziomie wiążą się z obecnością potrzeb i piszę o nich w pierwszej kolejności. Abraham Maslow wprowadził znane rozróżnienie pomiędzy potrzebami biologicznymi i psychologicznymi, nadając im ponadto strukturę hierarchiczną (Maslow, 1986). Potrzeby niższego rzędu muszą zostać zaspokojone, aby człowiek mógł zaspokoić potrzeby zajmujące wyższe miejsce. Te najbardziej podstawowe wiążą się z fizjologią - m.in. pragnieniem, głodem, potrzebą oddychania czy snu. Następnie zaspokajane są potrzeby bezpieczeństwa, przynależności i miłości, szacunku i akceptacji, zaliczane do kategorii niedoboru. Oznacza to, że ich spełnienie redukuje napięcie. Po ich zaspokojeniu człowiek odczuwa potrzebę samorealizacji, która należy do grupy potrzeb wzrostu.

Istotny dynamizm ludzkiego działania - ważny w kontekście podjętych analiz - stanowi potrzeba poznania (need for cognition). To „cecha osobowości świadcząca o skłonności jednostki do podejmowania wymagającej wysiłku aktywności poznawczej. Osoby o ukształtowanej potrzebie poznawczej są złaknione informacji, lubią analizować złożone sytuacje i bawi je rozwiązywanie problemów, zwłaszcza trudnych" (Reber, Reber, 2005, s. 561). Z kolei Cohen, Stotland i Wolfe (1955) ujmują potrzebę poznania jako zamiar zaan- 
gażowania się w nadawanie znaczenia i odnajdowanie całościowej struktury istotnych zdarzeń. Jest to zatem dążenie do zrozumienia i dokonania racjonalnego uzasadnienia zasad panujących w świecie. Idea ta ma swoje źródło w założeniach psychologii Gestalt. Zgodnie z nimi, człowiek posiada naturalną potrzebę nadawania struktury otoczeniu, co uwalnia go od odczuwanego napięcia. W celu jego zredukowania podejmuje aktywny wysiłek, aby zrozumieć sens określonych zdarzeń. Autorzy potwierdzili empirycznie, że osoby o wysokiej potrzebie poznania cechuje pragnienie oceny treści, głębokiego ich opracowywania oraz nadania im struktury. Nie potrzebują też motywacji zewnętrznej, aby głębiej przetwarzać informacje, gdyż sam proces obróbki jest przezeń odbierany jako nagradzający. Cacioppo i Petty (1982) akcentują także, że potrzeba poznania ma charakter motywacyjny. Nie informuje zatem o zdolnościach poznawczych, ale o zaangażowaniu i czerpaniu przyjemności z zaangażowania w czynności. Wyniki badań własnych (Ledzińska, 2012) informują o ujemnej korelacji między nasileniem potrzeby poznania a natężeniem stresu informacyjnego $(r=-0,25 ; p<0,01)$. Rezultat ten potwierdza przytoczone wcześniej stwierdzenia o naturze potrzeby poznawczej: nie jest nią „pogoń za nowością”, lecz dążenie do zrozumienia.

Wyższe mechanizmy regulacji zachowania wiąże się zazwyczaj ze światem wartości oraz obrazem świata i własnej osoby (Jarymowicz, 2008). Przekonania na swój temat stanowią m.in. domenę badań nad Ja. To odrębny, bardzo rozległy i zróżnicowany obszar studiów psychologów osobowości (Bąk, 2017; Oleś, 2009). Uwagę wielu badaczy przyciąga wiedza na temat Ja, stanowiąca element samowiedzy. Studia te nawiązują do taksonomii Williama Jamesa (1890), który wyróżnił Ja przedmiotowe oraz podmiotowe. Człowiek poznaje nie tylko świat zewnętrzny, ale i siebie. Może opisywać Ja, będące złożoną i dynamiczną strukturą poznawczą. Do najczęściej badanych ogniw Ja zalicza się samoocenę, samoakceptację czy poczucie własnej wartości. Charakteryzuje się je pod względem treściowym i formalnym, biorąc pod uwagę m.in. złożoność, klarowność i przedziałowość (Huflejt-Łukasik, Bąk, Styła, Klajs, 2015).

Ja jest też przedmiotem wielu odrębnych ujęć koncepcyjnych (Bąk, 2017). Jednym z nich jest teoria rozbieżności Ja Higginsa (1987). Zdaniem badacza Ja stanowi system przekonań na temat własnej osoby, traktowanej jako wyodrębniony, szczególnie ważny dla jednostki obiekt poznania. Tak rozumiany odgrywa fundamentalną rolę w procesach samoregulacji. Stosunek do siebie jest funkcją oceny własnych postępów oraz sukcesów w obszarach postrzeganych subiektywnie jako ważne. Ocena ta generalizowana jest na ogólny sąd na 
temat siebie i własnej wartości. Pozytywny stosunek do siebie i innych pełni ważną rolę regulacyjną: kształtuje dobrostan jednostki oraz rodzi zaufanie do innych, sprzyja też poszukiwaniu optymalnych rozwiązań codziennych trudności, co pozwala na zdobycie nowych kompetencji i podtrzymanie wiary we własną skuteczność (Greenberg, Arndt, 2012). Poczucie własnej wartości jest skorelowane z pozytywnymi emocjami, będącymi fundamentem dobrego samopoczucia i dobrostanu. Postrzeganie siebie jako osoby cechującej się wartościowymi i pożądanymi przymiotami buduje wysoką samoocenę. Jedną z najistotniejszych konsekwencji poczucia własnej wartości jest odczuwane bezpieczeństwo (Trzebińska, 2008). Człowiek dąży zatem do podtrzymania dobrego obrazu Ja - stąd tendencja do selektywnego przetwarzania informacji na swój temat. Pozytywne przekonania o sobie mają bowiem - przy optymalnym ich natężeniu - charakter przystosowawczy (Moskowitz, 2009). W relacjach społecznych preferujemy też osoby o poglądach zbliżonych do naszych, co utwierdza nas w przekonaniu o ich słuszności.

Badania raportowane w niniejszym tekście oparto na następujących przesłankach:

1) Człowiek odbiera nie tylko informacje docierające z zewnątrz, ale sam stanowi ważne ich źródło. Wydobywa informacje z pamięci, wytwarza je w procesie myślenia i wyobrażania.

2) Ważnym rodzajem informacji pozostają te dotyczące nas samych. Dostarcza ich obserwacja wyników własnych działań oraz relacje otoczenia. Te potwierdzające pozytywne przekonania na nasz temat stabilizują psychikę.

3) Brak napięć w psychice - zwłaszcza w obrębie Ja - ułatwia wykorzystanie zasobów potrzebnych do przetworzenia informacji docierających z zewnątrz, połączenia ich z posiadaną wiedzą, wydobywania i efektywnego wykorzystania.

4) Przeżywane napięcia wiążą się z obecnością zagrażających myśli oraz negatywnych emocji. Wysiłki podejmowane w celu uporania się z nimi absorbują uwagę, utrudniając odbiór i przetwarzanie bieżących informacji.

Celem badań uczyniono poznanie związków między wymiarami Ja dostępnymi diagnozie psychologicznej a poczuciem stresu informacyjnego. 


\section{MetodA}

\section{Osoby badane}

Badania przeprowadzono latach 2019-2020. Respondenci to młodzi dorośli, czyli osoby z przedziału wieku 18-35 lat ${ }^{1}$. W kilku odrębnych programach uczestniczyło łącznie 601 osób $(M=23,65 ; S D=4,12)$.

\section{Zmienne i narzędzia ich pomiaru}

\section{Poczucie stresu informacyjnego.}

Kwestionariusz do badania siły doznań stresu informacyinego (KSI-R). Pierwsza, wstępna wersja KSI stworzona została przed laty (Ledzińska, 2002). Narzędzie o bardzo dobrych własnościach psychometrycznych ocenili respondenci jako „zbyt długie i nużące”. Zrewidowana wersja techniki - licząca 45 stwierdzeń - powstała w wyniku wyeliminowania pozycji o najniższej mocy dyskryminacyjnej. Narzędzie to zastosowano w serii badań z udziałem młodych dorosłych. Najważniejsze wyniki opublikowane zostały w monografiach (Ledzińska, 2009, 2012). Ostatnią wersję - zastosowaną m.in. w raportowanych badaniach - stanowi KSI-R, powstały w wyniku zastosowania analiz IRT (Demars, 2010; Kominiarczuk, 2017; Watson i in., 2011; Zawadzki, 2006). Kwestionariusz zawiera 23 stwierdzenia. Respondenci zakreślają odpowiedzi na 4-stopniowej skali: 1 - nigdy, 2 - czasem, 3 - często, 4 - zawsze. Wynik końcowy obliczany jest przez zsumowanie wszystkich wyborów. Rezultaty każdej z osób badanych zawierają się w przedziale 23-92 punkty. Własności psychometryczne skróconego narzędzia okazały się bardzo dobre; rzetelność mierzona zgodnością wewnętrzną przyjęła wartość alfa Cronbacha 0,93 (Wiśniewska, 2019; Wiśniewska, Ledzińska, 2020). Jako miarę trafności przyjęto korelację między rezultatem w KSI-R a wynikiem w Kwestionariuszu poczucia stresu Plopy i Makarowskiego (2010). Uzyskano wartość $r=0,67(p<0,01)$.

\footnotetext{
1 Materiał zgromadziły w ramach prac magisterskich panie: K. Kwiatkowska, Ż. Kaźmierska, O. Leszczyńska, S. Valdemoro Gimenez. Badanie nad związkiem między stresem informacyjnym a samooceną przeprowadzono w środowisku internetowym, pozostałe przez kontakt bezpośredni.
} 


\section{Prężność psychiczna.}

Kwestionariusz pręiności (SPP-25). Na tę indywidualną właściwość składa się samoświadomość, poczucie własnej wartości i pewności (Werner, Smith, 1982). Ujmowana jest jako względnie trwała dyspozycja, czyli cecha osobowości determinująca proces elastycznej adaptacji do zmieniających się wymagań życiowych. Nazywana bywa rezyliencją lub prężnością ego (Uchnast, 1997). Narzędzie autorstwa Ogińskiej-Bulik i Juczyńskiego (2008) zawiera 25 stwierdzeń, do których respondenci ustosunkowują się, wybierając odpowiedź od $z$ decydowanie nie - 0 punktów, do $z$ decydowanie tak - 4 punkty. Rzetelność ustalana metodą zgodności wewnętrznej wyniosła 0,89 .

\section{Stosunek do siebie i innych.}

Kwestionariusz ustosunkowań (KU). Technika autorstwa Sukiennik (2012) służy do pomiaru pozytywności stosunku do siebie i innych ludzi (Harris, 2009). Oparta została na tezach analizy transakcyjnej oraz modelu więzi emocjonalnych Bartholomew i Horovitza (1991). Narzędzie zawiera 73 pozycje, które dzielą się na dwie skale: JA-OK (42 pozycje) i WY-OK (31 pozycji). Osoby badane mogą oceniać sformułowania zawarte w kwestionariuszu, odnosząc je siebie na 4-stopniowej skali: 1 - nie zgadzam się, 2 - raczej nie zgadzam się, 3 - raczej zgadzam się, 4 - zgadzam się. Maksymalny wynik, jaki można osiągnąć na skali JA-OK, wynosi 168 punktów, a na skali WY-OK - 124 punkty. Wskaźnik rzetelności ustalany metodą zgodności wewnętrznej wyniósł 0,90.

\section{Geneza standardów Ja.}

Moje cechy pożądane (MCP). Technika opracowana przez Chrzanowską (2009) umożliwia diagnozę stopnia niezależności standardów Ja. Uwzględnia dwa wymiary standardów Ja: zewnętrzny i wewnętrzny. Badani mają za zadanie wygenerowanie charakterystyk, jakimi pragnęliby się cechować. W tym celu proszeni są o spontaniczne wypisanie cech, które chcieliby posiadać, nazwanych w badaniu „cechami pożądanymi”. Kolejnym zadaniem jest określenie na 7-stopniowej skali (od $1-w$ bardzo małym stopniu, do 7 - w bardzo dużym stopniu), jak bardzo inni oczekują od badanego, by takim był, a w jakim stopniu on sam chce taki być. Finalnie ustala się iloraz stopnia oczekiwań wobec siebie do oczekiwań społecznych. Im wyższa wartość ilorazu, tym mniejsza zależność Ja wobec oczekiwań otoczenia. Technika została wielokrotnie zastosowana w badaniach nad podmiotowością, zrealizowanych w Katedrze Psychologii Osobowości UW (Jarymowicz, 2008). 


\section{Samoocena.}

Skala samooceny (SES). Narzędzie stworzone przez M. Rosenberga mierzy ogólny poziom samooceny, czyli stosunek do własnej osoby ujawniany w samoopisie. Technika zawiera 10 pozycji, a badani zaznaczają odpowiedzi na skali 1-4 (od zdecydowanie nie zgadzam się, do zdecydowanie zgadzam się). Rzetelność polskiej adaptacji (Łaguna, Lachowicz-Tabaczek, Dzwonkowska, 2007) mierzona zgodnością wewnętrzną wynosi 0,81-0,83.

\section{Rozbieżność Ja.}

Skala niespójności Ja(SN-Ja). Technika stworzona przez Styłę, Jankowskiego i Suszka (2010) stanowi przykład narzędzia samoopisowego umożliwiającego pomiar integracji struktury Ja. Badany ma za zadanie ocenić siebie za pomocą siedmiu charakterystyk (aktywny, otwarty, lojalny, pewny siebie, zaradny, niezależny, bezpośredni) w kontekście pięciu ról społecznych (jako student / partner / syn / kolega, przyjaciel / pracownik). Natężenie tych cech respondent zaznacza na 7-stopniowej skali (gdzie 1 oznacza niskie nasilenie, a 7 - wysokie nasilenie cechy). Skala SN-Ja zawiera zatem 35 pozycji. Wynik końcowy to średnia odchyleń standardowych natężenia cech w wyróżnionych rolach społecznych. Wysoki rezultat informuje o wysokiej niespójności Ja, a niski - o integracji Ja. Rzetelność mierzona zgodnością wewnętrzną to 0,75.

\section{WYNIKI}

Poniżej zaprezentowano najważniejsze rezultaty.

Tabela 1

Statystyki opisowe dla analizowanych zmiennych

\begin{tabular}{lrc}
\hline \multicolumn{1}{c}{ Zmienne } & $\boldsymbol{M}$ & SD \\
\hline Prężność & 50,49 & 11,03 \\
Stres informacyjny & 62,13 & 15,82 \\
Stosunek do siebie & 126,11 & 16,73 \\
Stosunek do innych & 85,29 & 13,45 \\
Stres informacyjny & 46,38 & 10,42 \\
Moje cechy pożądane & 1,47 & 0,41 \\
Stres informacyjny & 52,45 & 12,50 \\
Samoocena & 29,62 & 5,74 \\
Stres informacyjny & 50,85 & 10,24 \\
\hline
\end{tabular}

Ciąg dalszy tabeli na następnej stronie 
Ciąg dalszy tabeli z poprzedniej strony

\begin{tabular}{lcc}
\hline \multicolumn{1}{c}{ Zmienne } & $\boldsymbol{M}$ & SD \\
\hline Niespójność Ja & 0,82 & 0,35 \\
Stres informacyjny & 47,49 & 12,61 \\
\hline
\end{tabular}

Tabela 2

Zwiq̨zki między różnymi wymiarami Ja a poczuciem stresu informacyjnego

\begin{tabular}{lccc}
\hline \multicolumn{1}{c}{ Wymiary Ja } & Liczba osób & $\begin{array}{c}\text { Współczynnik } \\
\text { korelacji } r \text {-Pearsona }\end{array}$ & Istotność \\
\hline Prężność & 50 & $-0,56$ & 0,001 \\
Stosunek do siebie & 100 & $-0,44$ & 0,01 \\
Stosunek do innych & 100 & $-0,19$ & 0,05 \\
Samoocena & 270 & $-0,25$ & 0,001 \\
Stopień niezależności standardów Ja & 101 & $-0,21$ & 0,05 \\
Rozbieżnoś́ Ja & 88 & 0,47 & 0,001 \\
\hline
\end{tabular}

Z przedstawionych powyżej badań wysnuć można następujące wnioski.

1. Wyniki wszystkich relacjonowanych postępowań ujawniły istotne statystycznie korelacje między diagnozowanymi aspektami Ja a poczuciem stresu informacyjnego.

2. W przypadku zmiennej rozbieżność Ja jest to korelacja dodatnia, a w odniesieniu do pozostałych czterech wymiarów - ujemna. Pozyskane wyniki są ze sobą spójne.

3. Struktura Ja stanowi znaczący podmiotowy wyznacznik siły doznań stresu informacyjnego.

\section{Podsumowanie I dYsKusJa}

W pierwszej kolejności odnoszę wyniki do wcześniejszych badań nad stresem. Ujemna korelacja między prężnością a siłą stresu informacyjnego wydaje się mieć charakter ogólnej zależności. Wskazują na to m.in. rezultaty przywoływane przez Ogińską-Bulik i Juczyńskiego (2008). Prężność nazywana bywa też adaptacyjną elastycznością, umiejętnością dostosowania kontroli do specyfiki sytuacji. Sprężystością i związaną z nią kontrolą ego wyjaśnia się efek- 
tywne funkcjonowanie w stresie i radzenie sobie z nim. Frederickson, Tugade, Waugh i Larkin (2003) akcentują, że osoby o wysokiej sprężystości psychicznej wykorzystują emocje pozytywne, by podwyższyć funkcjonowanie w sytuacjach trudnych poprzez lepsze wykorzystanie zasobów. Emocje o dodatnim znaku pomagają bowiem „oderwać się" od negatywnych doznań. Ujemne korelacje między pozostałymi trzema charakterystykami Ja (wysoka samoocena, pozytywny stosunek do siebie i innych, niezależność standardów od otoczenia) a natężeniem badanego stresu można zinterpretować w podobny sposób.

Raportowane rezultaty pozostają też $\mathrm{w}$ zgodzie $\mathrm{z}$ wynikami badań nad regulacyjną rolą Ja (m.in. Bąk, 2017; Huflejt-Łukasik i in., 2015; Jarymowicz, 2008; Oleś, 2009; Suszek, 2007). Pozytywnemu stosunkowi do siebie (i innych) towarzyszą emocje o dodatnim znaku. Ich rolę w obniżaniu stresu informacyjnego można zinterpretować, zwracając uwagę na dwa fakty:

- po pierwsze: pozwalają swobodnie eksplorować otoczenie, zdobywać w nim orientację, a ponadto ułatwiają utrzymywanie kontaktu ze sobą oraz innymi;

- po drugie: sprzyjają refleksyjności, czyli krytycznemu namysłowi nad dostępnymi treściami - ułatwiając ocenę, a więc i selekcję.

Wybór wiąże się z procesem wartościowania. Może ono dokonywać się automatycznie oraz refleksyjnie, tj. z udziałem krytycznego myślenia. Oceny bezwiedne, afektywne są ontogenetycznie wcześniejsze. Nie wymagają świadomości i podporządkowane są potrzebom obronnym oraz adaptacyjnym. Odgrywają istotną rolę w utrzymaniu homeostazy i podtrzymaniu życia. Regulacja automatyczna zastępowana jest stopniowo przez tzw. emocje cywilizowane, czyli związane ze świadomością (Imbir, 2018; Jarymowicz, 2008). Ocenianie w coraz większym stopniu angażuje myślenie. Przemyślane sądy dokonywane są w oparciu o zwerbalizowane standardy (Gołąb, Reykowski, 1985). Wzrost refleksyjności oznacza w praktyce życia codziennego dokonywanie świadomych wyborów, także tych dotyczących dostępnych informacji. Człowiek może ocenić dostępne treści jako zgodne lub niezgodne z jego systemem wartości, sprawdzone bądź niewiarygodne, przydatne albo niepotrzebne w konkretnej sytuacji.

Dodatnią korelację między niespójnością Ja a natężeniem informacyjnego stresu można z kolei wyjaśnić, odwołując się do negatywnych emocji towarzyszących owej rozbieżności. Szczególną rolę wydaje się odgrywać lęk (wyniki opracowywanych badań własnych pokazują, że koreluje on dodatnio 
w stopniu istotnym statystycznie z rozbieżnością Ja). Ma on zdaniem Eysencka i Calvo (1992) szeroki zakres oddziaływania na funkcjonowanie poznawcze. Wpływa w pierwszej kolejności na pracę uwagi, a jego rola jest tym większa, im bardziej rosną wymagania poznawcze. Lęk dezorganizuje pracę uwagi w każdym jej aspekcie. Ważne jest zwłaszcza osłabienie kontroli uwagowej. Jeśli podczas aktywności poznawczej rodzi się obawa o to, czy podołamy zadaniu, to lęk indukuje myśli z nim niezwiązane. Te dystraktory nie mogą być przez człowieka pominięte i pochłaniają zasoby potrzebne do realizacji zadań typu wybieranie informacji, ich strukturalizowanie, wiązanie ich z posiadaną wiedzą itp. Oddziaływanie lęku nie jest przy tym krótkotrwałe, ale rozciągnięte $\mathrm{w}$ czasie. Jest też silniejsze u jednostek o większym natężeniu lęku, jako bardziej podatnych na zakłócenia. Lęk jest bowiem związany ze wzrostem wrażliwości na dystraktory, wyczula na nie (m.in. Eysenck, 2006; Matthews, Campbell, 2009; Szymura, 2007). Osoby doświadczające lęku poprzez zredukowaną kontrolę uwagową - mają ograniczone możliwości ignorowania i eliminowania bodźców zakłócających. Zjawisko nasila się, gdy w grę wchodzą bodźce zagrażające. Przyciągają one uwagę osób lękowych na tyle, że pisze się wręcz o tendencyjnym funkcjonowaniu ich uwagi. Pozostaje ona pod stałym naciskiem bodźców zagrażających. Lęk ułatwia bowiem wykrywanie bodźców sygnalizujących potencjalne niebezpieczeństwo - to jedna $\mathrm{z}$ jego podstawowych funkcji.

Stwierdzenia podsumowujące wyniki relacjonowanych badań brzmią następująco. Ja ujmowane na wymiarach prężności, samooceny, niezależności standardów oceny i pozytywnego stosunku do siebie oraz innych optymalizuje funkcjonowanie człowieka w globalnym środowisku życia. Te „pozytywne” aspekty Ja wiążą się bowiem ze słabszym przeżywaniem jednej ze współczesnych odmian stresu. Można je zatem traktować jako ważny, ponadczasowy zasób. Niespójności Ja towarzyszą z kolei silniejsze doznania stresu informacyjnego. Teza o regulacyjnej roli Ja ma w psychologii osobowości bardzo bogatą dokumentację empiryczną. Zaprezentowane rezultaty - uwzględniające specyfikę środowiska życia - ilustrują zatem ogólną zależność. Ja ułatwia adaptację do globalnego środowiska życia ujmowanego w jego nurcie informacyjnym. Badania należy replikować. Warto też przeprowadzić je z udziałem osób $\mathrm{z}$ innych grup wiekowych. 


\section{BiBLIOGRAFIA}

Bartholomew, K., Horowitz, L. M. (1991). Attachment styles among young adults: A test of a four-category model. Journal of Personality and Social Psychology, 61(2), 226-244. https://doi.org/10.1037/0022-3514.61.2.226

Bawden, D., Robinson, L. (2009). The dark side of information: Overload, anxiety and other paradoxes and pathologies. Journal of Information Science, 35(2), 180-191. https://doi.org/10.1177/0165551508095781

Bąk, W. (2017). Standardy Ja. Hierarchiczny model samowiedzy. Warszawa: Liberi Libri.

Bielawski, K. (oprac.). (2018). Delficki trójnóg. Sentencje delfickie. Kraków: Wydawnictwo Uniwersytetu Jagiellońskiego.

Cacioppo, J. T., Petty, R. E. (1982). The need for cognition. Journal of Personality and Social Psychology, 42(1), 116-131. https://doi.org/10.1037/0022-3514.42.1.116

Chrzanowska, A. (2009). Osobiste standardy wartościowania a przejawy postaw wobec Swoich i Obcych w próbie wolontariuszy hospicyjnych i kontrolnej (Niepublikowana praca magisterska). Uniwersytet Warszawski. Warszawa.

Cohen, A. R., Stotland, E., Wolfe, D. M. (1955). An experimental investigation of need for cognition. Journal of Abnormal and Social Psychology, 51(2), 291-294. https:// doi.org/10.1037/h0042761

Demars, C. (2010). Item response theory: Understanding statistic measurement. Oxford: Oxford University Press.

Eco, U. (2007). O bibliotece. Warszawa: Świat Książki.

Eppler, M. J., Mengis, J. (2004). The concept of information overload: A review of literature from organization science, accounting, marketing, MIS, and related disciplines. The Information Society, 20(5), 325-344. https://doi.org/10.1080/01972240490507974

Eysenck, M. W. (2006). Teorie lęku i wykonanie zadań poznawczych. W: M. Fajkowska, M. Marszał-Wiśniewska, G. Sędek (red.), Podpatrywanie myśli i uczuć (s. 87-100). Gdańsk: Gdańskie Wydawnictwo Psychologiczne.

Eysenck, M. W., Calvo, M. G. (1992). Anxiety and performance: The processing efficiency theory. Cognition and Emotion, 6(6), 409-434. https://doi. org/10.1080/02699939208409696

Fredrickson, B. L., Tugade, M. M., Waugh, C. E., Larkin, G. R. (2003). What good are positive emotions in crisis? A prospective study of resilience and emotions following the terrorist attacks on the United States on September 11th, 2001. Journal of Personality and Social Psychology, 84(2), 365-376. https://doi.org/10.1037/00223514.84.2.365

Girard, J., Allison, M. (2008). Information anxiety: Fact, fable or fallacy. Electronic Journal of Knowledge Management, 6(2), 111-124. 
Gołąb, A., Reykowski, J. (1985). Studia nad rozwojem standardów ewaluatywnych. Wrocław: Ossolineum.

Greenberg, J., Arndt, J. (2012). Terror management theory. W: P. Van Lange, A. Kruglanski, E. Higgins (red.), The handbook of theories of social psychology (s. 398-415). Londyn: Sage Publications.

Harris, T. (2009). Ja jestem OK - Ty jesteś OK. Poznań: Dom Wydawniczy Rebis. Higgins, E. T. (1987). Self-discrepancy: A theory relating self and affect. Psychological Review, 94(3), 319-340. https://doi.org/10.1037/0033-295X.94.3.319

Hobfoll, S. E. (2006). Stres, kultura i społeczność. Psychologia i filozofia stresu. Gdańsk: Gdańskie Wydawnictwo Psychologiczne.

Heszen, I. (2013). Psychologia stresu. Warszawa: Wydawnictwo Naukowe PWN.

Huflejt-Łukasik, M., Bąk, W., Styła, R., Klajs, K. (2015). Zmiany w Ja w toku psychoterapii. Roczniki Psychologiczne, 18(3), 433-448.

Imbir, K. (2018). Dwa systemy emocji i ich konsekwencje dla procesów poznawczych. Warszawa: Wydawnictwa UW.

James, W. (1890). The principles of psychology. Nowy Jork: Henry Holt and Company. Jarymowicz, M. (2008). Psychologiczne podstawy podmiotowości. Warszawa: Wydawnictwo Naukowe PWN.

Kępiński, A. (2003). Melancholia. Warszawa: PZWL.

Kominiarczuk, N. (2017). IOS - Mokken Scale Analysis. Nottingham: University of Nottingham. Niepublikowany manuskrypt.

Lazarus, R. S., Folkman, S. (1984). Stress, appraisal and coping. Nowy Jork: Springer.

Lazarus, R. S., Folkman, S. (1987). Transactional theory and research on emotions and coping. European Journal of Personality, 1(3), 141-169. https://doi.org/10.1002/ per. 2410010304

Ledzińska, M. (2001). Człowiek współczesny wobec nadprodukcji informacji, czyli o informacyjnym stresie. W: A. Matczak, W. Ciarkowska (red.), Różnice indywidualne: wybrane zagadnienia inspirowane Regulacyjna Teoria Temperamentu Profesora Jana Strelaua (s. 135-153). Warszawa: Uniwersytet Warszawski.

Ledzińska, M. (2002). W poszukiwaniu sposobu diagnozy sity doznań stresu informacyjnego - kwestionariusz KSI. Niepublikowany manuskrypt.

Ledzińska, M. (2009). Człowiek współczesny w obliczu stresu informacyjnego. Warszawa: Wydawnictwo Instytutu Psychologii PAN.

Ledzińska, M. (2012). Młodzi dorośli w dobie globalizacji. Szkice psychologiczne. Warszawa: Difin.

Ledzińska, M. (2017). Nauczyciela akademickiego spojrzenie na rozwój w dobie przemian ogólnoświatowych. Psychologia Rozwojowa, 22(1), 9-25. https://doi.org/10. 4467/20843879PR.17.001.6415 
Ledzińska, M. (2020). Paradoks dostępności: perspektywa psychologiczna. W. K. Bargiel-Matusiewicz, M. Ledzińska (red.), Psychologiczne mechanizmy regulacji z perspektywy zdrowia $i$ choroby (s. 115-138). Warszawa: Liberi Libri.

Ledzińska, M., Czerniawska, E. (2011). Psychologia nauczania: ujęcie poznawcze. Warszawa: Wydawnictwo Naukowe PWN.

Ledzińska, M., Postek, S. (2017). From metaphorical information overflow and overload to real stress: Theoretical background, empirical findings and applications. European Management Journal, 35(6), 785-793.

Ledzińska, M., Zajenkowski, M., Stolarski, M. (2013). Temperament i poznanie. Energetyczne i czasowe zaplecze umystu. Warszawa: Wydawnictwo Naukowe Scholar.

Levine, N. (2017). The nature of the glut: Information overload in postwar America. History of the Human Science, 30(1), 32-49. https://doi.org/10.1177/0952695116686016 Levinson, J. (1999). Miękkie ostrze. Warszawa: Muza S.A.

Littleton, K., Wood, C., Kleine Staarman, J. (2010). International handbook of psychology in education. Bingley: Emerald.

Łaguna, M., Lachowicz-Tabaczek, K., Dzwonkowska, I. (2007). Skala Samooceny SES Morrisa Rosenberga - polska adaptacja metody. Psychologia Społeczna, 2 02(04), 164-176.

Łosiak, W. (2008). Psychologia stresu. Warszawa: Wydawnictwa Akademickie i Profesjonalne.

Maslow, A. H. (1986). W stronępsychologii istnienia. Warszawa: Instytut Wydawniczy PAX.

Matthews, G., Campbell, S. E. (2009). Sustained performance under overload: Personality and individual differences in stress and coping. Theoretical Issues in Ergonomics Science, 10(5), 417-442. https://doi.org/10.1080/14639220903106395

McLuhan, H. M., McLuhan, E. (1992). Laws of media. The new science. Toronto-Buffalo-Londyn: University of Toronto Press.

Mellon, C. A. (1986). Library anxiety: A grounded theory and its development. College \& Research Libraries, 47, 160-165.

Morbitzer, J. (2007). Edukacja wspierana komputerowo a humanistyczne wartości pedagogiki. Kraków: Wydawnictwo Naukowe Akademii Pedagogicznej.

Moskowitz, G. (2009). Zrozumieć siebie i innych. Psychologia poznania społecznego. Gdańsk: Gdańskie Wydawnictwo Psychologiczne.

Nęcka, E., Orzechowski, J., Szymura, B. (2006). Psychologia poznawcza. Warszawa: Wydawnictwo Naukowe PWN.

Ogińska-Bulik, N., Juczyński, Z. (2008). Skala pomiaru prężności. Nowiny Psychologiczne, 3, 39-55.

Oleś, P. (2009). Wprowadzenie do psychologii osobowości. Warszawa: Wydawnictwo Naukowe Scholar. 
Oniszczenko, W., Ledzińska, M. (2019). Sex, affective temperaments and information stress. International Journal of Occupational Medicine and Environmental Health, 32(5), 635-644. https://doi.org/10.13075/ijomeh.1896.01392

Petty, R., See, Y. H. M. (2007). Need for cognition. W: F. Baumeister, K. D. Vohs (red.), Encyclopedia of social psychology (s. 611-613). Los Angeles-Londyn-New Delhi-Singapore: Sage Publications.

Plopa, M., Makarowski, R. (2010). Kwestionariusz Poczucia Stresu. Warszawa: Vizja. Postek, S., Ledzińska, M. (2015). Temperamentalne predyktory stresu informacyjnego w grupie menadżerów wysokiego szczebla. Psychologia - Etologia - Genetyka, 31, 69-87.

Reber, A. S., Reber, E. S. (2005). Słownik psychologii. Warszawa: Wydawnictwo Naukowe Scholar.

Shenk, D. (1997). Data smog: Surviving the information glut. Nowy Jork: Harper Collins. Stiglitz, J. E. (2004). Globalizacja. Warszawa: Wydawnictwo Naukowe PWN.

Straś-Romanowska, M. (2016). Podmiot osobowy w świecie współczesnym. Psychologia Rozwojowa, 21(2), 15-25. https://doi.org/10.4467/20843879PR.16.007.5085

Strelau, J. (2014). Różnice indywidualne. Historia, determinanty, zastosowania. Warszawa: Wydawnictwo Naukowe Scholar.

Styła, R., Jankowski, K. S., Suszek, H. (2010). Skala Niespójności Ja (SN-JA). Studia Psychologiczne, 48, 31-43.

Sukiennik, A. (2012). Kwestionariusz Ustosunkowań KU. Podręcznik. Warszawa: Pracownia Testów Psychologicznych PTP.

Suszek, H. (2007). Różnorodność wielości Ja. Roczniki Psychologiczne, 10(2), 7-37.

Szymura, B. (2007). Temperament uwagi. Kraków: Universitas.

Targowski, A. (2015). The limits of civilization. Nowy Jork: Nova Science Pub Inc.

Trzebińska, E. (2008). Psychologia pozytywna. Warszawa: Wydawnictwa Akademickie i Profesjonalne.

Uchnast, Z. (1997). Prężność osobowa: empiryczna typologia i metoda pomiaru. Roczniki Filozoficzne, 45(4), 27-51.

Watson, R., van der Ark, A., Lin, L. C., Fieo, R. (2011). Item response theory: How Mokken scaling can be used in clinical practice. Journal of Clinical Nursing, 21(19-20), 2736-2746. https://doi.org/10.1111/j.1365-2702.2011.03893.x

Werner, E. E., Smith, R. S. (1982). Vulnerable but invincible: A longitudinal study of resilient children and youth. Nowy Jork: McGraw-Hill.

Wiśniewska, D. (2019). Badanie własności psychometrycznych skróconej wersji KSI-R. Niepublikowany manuskrypt.

Wiśniewska, D., Ledzińska, M. (2020). Stres informacyjny w doświadczeniu osób w różnym wieku. W: M. Kielar-Turska (red.), Starość - jak ja widzi psychologia. 
Szanse rozwoju w starości (s. 345-368). Kraków: Wydawnictwo Naukowe Akademii Ignatianum.

Wurman, R. S. (1987). Information anxiety. Nowy Jork: Doubleday.

Zawadzki, B. (2006). Kwestionariusze osobowości. Procedura i strategie konstruowania. Warszawa: Wydawnictwo Naukowe Scholar. 
Dorota KoBYLiŃsKA iD https://orcid.org/0000-0003-0184-2595

Wydział Psychologii, Uniwersytet Warszawski

ZuZAnNa Molenda

Instytut Psychologii, Polska Akademia Nauk

Magdalena Śmieja

Instytut Psychologii, Uniwersytet Jagielloński

MARIA WASYLKOWSKa

Wydział Psychologii, Uniwersytet Warszawski

\section{Inteligencja emocjonalna a rozpiętość repertuaru strategii regulacji emocji i ich efektywność \\ Emotional intelligence and emotion regulation strategies repertoire and effectiveness}

Sposób cytowania: Kobylińska, D., Molenda, Z., Śmieja, M., Wasylkowska, M. (2021). Inteligencja emocjonalna a rozpiętość repertuaru strategii regulacji emocji i ich efektywność. W: M. Huflejt-Łukasik, A. Pluta (red.), Mechanizmy psychologiczne i społeczne warunkujące formułowanie ocen oraz podejmowanie działań (s. 41-58). Warszawa: Wydawnictwo Liberi Libri. https://doi.org/10.47943/lib.9788363487553.rozdzial02 


\section{Streszczenie}

Wysoka inteligencja emocjonalna (IE) pozwala elastycznie radzić sobie z trudnościami, łatwo adaptować się do zmian i daje możliwość korzystania $\mathrm{z}$ szerokiego repertuaru strategii radzenia sobie $\mathrm{w}$ trudnych sytuacjach. Z kolei szeroki repertuar strategii odgrywa kluczową rolę w skutecznej regulacji emocji i jest ważnym aspektem elastycznej regulacji. Jednak do tej pory żadne badania nie dotyczyły bezpośrednio związku IE z elastyczną regulacją emocji. Celem naszego badania było sprawdzenie zależności między IE a szerokością repertuaru strategii (liczbą wszystkich stosowanych strategii), liczbą stosowanych strategii adaptacyjnych oraz efektywnością tych strategii. Uczestnicy $(N=180)$ wypełnili Kwestionariusz strategii regulacji emocji oraz Test inteligencji emocjonalnej za pośrednictwem platformy internetowej. Wyniki pokazały, że osoby $\mathrm{z}$ wyższą IE deklarowały stosowanie większej liczby strategii oraz stosowanie bardziej adaptacyjnych strategii niż osoby z niższą IE. Ponadto okazało się, że istnieje pozytywna korelacja między IE a subiektywnie ocenianą efektywnością stosowanych strategii. Wyniki te wydają się być obiecującym wstępem do dalszych badań nad elastyczną regulacją emocji.

Słowa kluczowe: inteligencja emocjonalna, regulacja emocji, elastyczność

\section{Abstract}

High emotional intelligence (EI) is supposed to allow people flexibly cope with difficulties, easily adapt to changes and use a broad repertoire of coping strategies. Moreover, a broadness of strategies repertoire may have a crucial role in effective emotion regulation and it is an important aspect of flexible regulation. However, no studies so far investigated the relationships of EI and flexible emotion regulation directly. The aim of the present research was to examine the relationship between the EI and: the broadness of strategies' repertoire (number of strategies 
used), the number of adaptive strategies used and the effectiveness of the strategies. Participants $(N=180)$ completed the Questionnaire of Emotion Regulation Strategies and Emotional Intelligence Test via Internet platform. We found that individuals with higher EI declared using more strategies as well as using more adaptive strategies than participants with lower EI. Furthermore, the results indicate that there is a positive correlation between EI and strategies' effectiveness. These results provide new findings on the relationship between emotion regulation and EI which is a promising direction for further research on flexible emotion regulation.

Keywords: emotional intelligence, emotion regulation, flexibility

Przyjmuje się, że osoby o wysokiej inteligencji emocjonalnej (IE) mają umiejętność elastycznego radzenia sobie z trudnościami, łatwo adaptują się do zmian swojego stanu emocjonalnego oraz stosują szeroki repertuar strategii radzenia sobie, $\mathrm{w}$ tym strategii regulacji emocji. Jednak żadne badania nie sprawdzały do tej pory bezpośrednio zależności między IE a elastyczną regulacją emocji. W tym artykule przedstawiono pierwszą i z pewnością wstępną próbę sprawdzenia istnienia tej zależności. Skupiłyśmy się na zbadaniu, czy IE wiąże się z jednym $\mathrm{z}$ aspektów elastycznej regulacji - szerokością repertuaru stosowanych strategii.

\section{Inteligencja emocjonalna}

Badacze nie są zgodni co do tego, jak definiować IE. Istnieją dwa główne podejścia teoretyczne (Śmieja, Orzechowski, 2008). Pierwsze z nich to model zdolnościowy Mayera, Saloveya i Caruso, zaproponowany już w latach dziewięćdziesiątych (Salovey, Mayer, 1990). Drugie podejście reprezentują tak zwane modele mieszane (Śmieja, Orzechowski, 2008). Do tej grupy należą konceptualizacje Golemana (1997) i Bar-Ona (1997). Modele mieszane proponują szerokie rozumienie IE, obejmujące cechy osobowości i kompetencje 
społeczne (Śmieja, Orzechowski, Beuvale, 2007). Wydaje się, że najbardziej kompleksową, spójną i ugruntowaną koncepcją IE (Śmieja i in., 2007) jest model Mayera, Saloveya i Caruso. Definiują oni IE jako umiejętność angażowania się w przetwarzanie skomplikowanych informacji o emocjach, zarówno swoich, jak i innych, myślenie o emocjach oraz wykorzystywanie emocji w celu wspomagania myślenia i innych procesów poznawczych, tak by wspierać rozwój emocjonalny i intelektualny (Mayer, Salovey, Caruso, 2004). Model ten zakłada istnienie czterech wymiarów IE: (1) percepcja emocji, (2) asymilacja emocji (3) rozumienie emocji oraz (4) zarządzanie emocjami.

Pierwszy wymiar - percepcja emocji - to umiejętność prawidłowego postrzegania, identyfikowania i rozpoznawania emocji w swoim własnym doświadczeniu, a także u innych (Śmieja, Orzechowski, Stolarski, 2014). Składają się na to: identyfikacja emocji w swoich stanach fizycznych, odczuciach lub myślach, rozpoznawanie emocji innych ludzi i postrzeganie obiektów nieożywionych (interpretowanie sztuki czy podobnych bodźców; Śmieja i in., 2007). To także umiejętność wyrażania emocji we właściwy sposób, dokładnie wtedy, kiedy jest to pożądane (Mayer, Caruso, Salovey, 2016).

Drugi wymiar to asymilacja emocji. Dotyczy ona umiejętności wykorzystywania emocji do usprawniania myślenia i rozwiązywania problemów oraz wpływu emocji na procesy poznawcze (Śmieja i in., 2014). Poprzez ten wymiar IE autorzy modelu podkreślają, że emocje mogą wpływać na rozwiązywanie problemów i podejmowanie decyzji w sposób efektywny i adaptacyjny (Mayer, Salovey, Caruso, 2008; Śmieja i in., 2007).

Trzecie wymiar - rozumienie emocji - polega na rozumieniu czynników wywołujących emocje, etapów procesu emocjonalnego i kolejności pojawiania się stanów emocjonalnych (Śmieja i in., 2014) oraz umiejętność rozróżniania nastrojów od emocji (Mayer i in., 2016). Tu także zawiera się umiejętność analizy emocji, rozumienia ich skutków i konsekwencji oraz docenienia znaczenia emocjonalnych doświadczeń (Mayer i in., 2004).

Ostatni, czwarty wymiar - zarządzanie emocjami - oznacza otwartość na emocje, monitorowanie ich i kierowanie nimi, ogólnie ujmując regulowanie własnych emocji oraz emocji innych ludzi (Fernández-Berrocal, Extremera, 2006). Wymiar dotyczy wykorzystywania strategii podtrzymywania, osłabiania lub intensyfikowania reakcji emocjonalnych (Mayer i in., 2016). Efektywne modyfikowanie emocji sprzyja, zdaniem autorów modelu, osiąganiu celów (Mayer i in., 2004).

Cztery opisane powyżej wymiary IE ułożone są w porządku hierarchicznym i są wymienione zgodnie $z$ miejscem w hierarchii. Percepcja emocji jest 
najbardziej podstawowym poziomem, a zarządzanie emocjami najbardziej złożonym (Fernández-Berrocal, Extremera, 2006). Autorzy modelu postulują, że najlepiej mierzyć IE jako umiejętność (Mayer i in., 2016).

Wiele dotychczasowych badań wykazało, że IE odgrywa ważną rolę $\mathrm{w}$ przewidywaniu adaptacyjnego funkcjonowania społecznego, $w$ tym satysfakcji w relacjach interpersonalnych, skutecznego radzenia sobie ze stresem i dobrostanu (Śmieja, 2018).

\section{Elastyczna regulacja emocji}

Istnieje kilka różnych koncepcji regulacji emocji (RE) w psychologii (Campos, Frankel, Camras, 2004; Garnefski, Kraaij, Spinhoven, 2001; Larsen, Prizmic, 1999; Wojciszke, 2003). Generalnie RE definiuje się jako procesy monitorowania, oceny i modyfikowania reakcji emocjonalnych, zwłaszcza ich intensywności i czasu trwania, wspierające osiąganie celów i intencji osoby (Thompson, 1994). Według Grossa $(2014,2015 a, 2015 b)$ RE to zespół procesów, za pomocą których jednostka wpływa na swoje emocje, zmieniając ich dynamikę, czas trwania, siłę oraz ich konsekwencje. Procesy te mają na celu osłabienie, wzmocnienie lub podtrzymanie doświadczania emocji negatywnych lub pozytywnych w zależności od potrzeb podmiotu i wymogów sytuacji (Gross, 2002, 2014). W swoim procesualnym modelu regulacji emocji Gross definiuje pięć grup strategii na podstawie tego, kiedy pojawiają się w sekwencji procesu generowania reakcji emocjonalnej. Są to: wybór sytuacji (situation selection), modyfikacja sytuacji (situation modification), kierowanie uwagą (attentional deployment), zmiana poznawcza (cognitive change) i zmiana reakcji (response modulation). Cztery pierwsze grupy strategii są klasyfikowane jako poprzedzające (antecedent-focused), gdyż pojawiają się przed wystąpieniem reakcji emocjonalnej (Gross, 2002; Ochsner, Gross, 2008, 2014). Piąta grupa jest klasyfikowana jako skoncentrowana na reakcji (response-focused). Strategie z tej grupy są uruchamiane już po wzbudzeniu emocji i dotyczą jej psychofizjologicznych, behawioralnych oraz doświadczeniowych skutków. Badania pokazują, że strategie poprzedzające są bardziej efektywne (niż te skoncentrowane na reakcji), ponieważ mogą wpływać na zmianę zarówno samej emocji, jak i jej konsekwencji (podczas gdy strategie zorientowane na reakcji zmieniają jedynie następstwa wystąpienia emocji, ale nie emocję samą w sobie).

W ostatnich latach coraz większym zainteresowaniem badaczy cieszy się tematyka elastycznej regulacji emocji (ERE). Od dawna podkreślano, że 
nieelastyczne sposoby radzenia sobie z różnymi wyzwaniami środowiskowymi są nieprzystosowawcze, szczególnie w bardzo niestabilnych i szybko zmieniających się warunkach życia człowieka (Aldao, Sheppes, Gross, 2015). W związku z tym uważa się, że większa elastyczność funkcjonowania, w tym elastyczność regulacji emocji, jest przydatna oraz adaptacyjna, wspiera zdrowie psychiczne i dobrostan (Aldao, Nolen-Hoeksema, 2012; Bonnano, Burton, 2014, Kashdan, Rottenberg, 2010; Westphal, Seivert, Bonanno, 2010).

Jedną z koncepcji ERE zaproponowali Aldao i in. (2015). Według nich ERE „odnosi się do zdolności wdrażania strategii RE, które są dostosowane do wymagań sytuacji” (s. 264). Twierdzą, że adaptacyjna wartość ERE jest nadal czymś, co należy raczej wykazać empirycznie niż jedynie teoretycznie zakładać.

Poszerzamy przedstawioną definicję, sądząc, że ERE polega na stosowaniu różnych strategii RE nie tylko w odniesieniu do kontekstu sytuacyjnego, ale także zgodnie z własnymi cechami osobowości (Kobylińska, Kusev, 2019). Pogląd ten jest zgodny z propozycją Doré i współpracowników (Doré, Silvers, Ochsner, 2016), którzy przedstawiają przegląd szeregu badań wskazujących na sytuacyjne i dyspozycyjne predyktory ER i sugerują, że obie grupy predyktorów powinny być brane pod uwagę w badaniu skuteczności strategii RE. Wydaje się bowiem, że żadna strategia nie jest zawsze i całkowicie dobra lub zła, skuteczna bądź nieskuteczna. Bardziej prawdopodobne jest, że różne strategie mogą być skuteczne bądź nie $\mathrm{w}$ radzeniu sobie $\mathrm{z}$ emocjami w określonych sytuacjach (Cheng, 2001; McRae, Heller, John, Gross, 2011; McRae, Ciesielski, Gross, 2012; Tamir, 2016; Westphal i in., 2010) oraz gdy stosowane są przez osoby o określonych cechach osobowości (Kobylińska, Marchlewska, 2017). Pogląd ten ma pewne wstępne uzasadnienie empiryczne. Na przykład Troy i współpracownicy (Troy, Shallcross, Mauss, 2013) zaproponowali podejście do RE, które nazwali osoba-w-sytuacji (person-by-situation approach) i wykazali, że u uczestników znajdujących się pod wpływem niekontrolowalnych stresorów (takich, na których występowanie nie mieli wpływu) stosowanie strategii ponownej oceny negatywnie korelowało z poziomem depresji, podczas gdy u osób będących pod wpływem stresorów kontrolowalnych - stosowanie ponownej oceny korelowało pozytywnie z poziomem depresji (Troy i in., 2013). To odkrycie sugeruje, że skuteczność ponownej oceny zależy od kontekstu sytuacyjnego, takiego jak rodzaj stresorów. Podobne wyniki uzyskano w badaniu Hainesa i in. (2016). Uczestnicy o stosunkowo wysokim dobrostanie częściej dokonywali ponownej oceny w sytuacjach, które postrzegali jako mniej kontrolowalne, niż w sytuacjach, które postrzegali jako bardziej kontro- 
lowalne. W innych badaniach Sheppes, Scheibe, Suri i Gross (2011) wykazali, że również sam wybór strategii regulacji jest powiązany z kontekstem. Kiedy bodźce miały niską intensywność, obciążenie poznawcze było niewielkie lub gdy wzbudzano cele długoterminowe, uczestnicy woleli regulować emocje, dokonując ponownej oceny, zaś gdy bodźce miały wysoką intensywność, obciążenie poznawcze było duże lub aktywowano cele krótkoterminowe uczestnicy woleli stosować dystrakcję. Autorzy argumentują, że wybór może odzwierciedlać to, co uczestnicy zakładają na temat skuteczności strategii: wybierają strategię, która ich zdaniem lepiej pomaga im radzić sobie z określonymi emocjami w określonej sytuacji.

Niektóre wcześniejsze badania sugerowały także, że pewne strategie mogą być bardziej skuteczne niż inne w przypadku osób z określonymi cechami. W jednym z badań (Kobylińska, Marchlewska, 2017) mierzono orientację na stan/działanie. Jest to jedna $\mathrm{z}$ różnic indywidualnych opisywanych jako względnie stałe dyspozycje, która jest istotnie związana $\mathrm{z}$ regulacją emocji (Koole, Coenen, 2007; Koole, Webb, Sheeran, 2015; Kuhl, 1992): osoby o wysokim poziomie orientacji na działanie $\mathrm{z}$ reguły bardziej skutecznie regulują emocje. Wyniki badania Kobylińskiej i Marchlewskiej (2017) pokazały, że orientacja na działanie wchodziła w interakcję ze wzbudzaną eksperymentalnie strategią regulacji emocji w przewidywaniu skuteczności regulacji w sytuacji awersyjnej: tłumienie było skuteczniejsze niż ponowna ocena u osób o niskim poziomie orientacji na działanie. Zatem specyficzna strategia, zwykle opisywana jako raczej nieprzystosowawcza i nieskuteczna w przypadku redukowania negatywnych emocji, może być jednak bardziej efektywna dla osób z pewnym poziomem danej cechy (tutaj: z niską orientacją na działanie) niż dla osób $\mathrm{z}$ innym poziomem tej cechy.

Także badania z zakresu psychologii pozytywnej pokazują, że niektóre strategie regulacji mające na celu polepszenie dobrostanu nie są tak samo skuteczne w przypadku osób o różnych cechach osobowości. Doświadczanie pozytywnych emocji było efektywnym sposobem na zwiększenie długoterminowego poczucia szczęścia dla osób o wysokim poziomie ekstrawersji i niskim poziomie neurotyczności, ale nie było skuteczne dla osób o niskim poziomie ekstrawersji oraz wysokim poziomie neurotyczności (Pavot, Diener, Fujita, 1990; Tamir, 2009).

Podsumowując, badania sugerują, że efektywność strategii RE jest zależna zarówno od od kontekstu sytuacyjnego, jak i od cech osoby, która reguluje swe emocje. 


\section{Badanie własne}

Zgodnie z teorią IE osoby o wysokim poziomie inteligencji emocjonalnej powinny stosować strategie, które są najskuteczniejsze w danej sytuacji (Salovey, Detweiler-Bedell, Detweiler-Bedell, Mayer, 2010). Skuteczność stosowania różnych strategii może zależeć od dyspozycyjnej wrażliwości na bodźce emocjonalne (Bonnano, Burton, 2014), a wrażliwość na bodźce emocjonalne znajduje odzwierciedlenie w zdolności percepcji EI. Sugeruje to, że IE powinna być związana z ERE. Bonnano i Burton (2014) opisali trzy komponenty ERE: szeroki i zróżnicowany repertuar strategii RE, wrażliwość na kontekst oraz reakcja na informacje zwrotne.

Nasze badanie było pierwszą i wstępną próbą sprawdzenia teoretycznie uzasadnionego związku między IE a ERE. Postanowiłyśmy sprawdzić, czy IE koreluje z szerokością repertuaru strategii RE oraz subiektywnie ocenianą efektywnością stosowanych strategii.

Przewidywałyśmy, że IE pozytywnie koreluje z ogólną liczbą stosowanych strategii (hipoteza 1) i liczbą stosowanych strategii adaptacyjnych (hipoteza 2), a także, że IE jest pozytywnie skorelowana z deklarowaną skutecznością stosowanych strategii regulacji emocji (hipoteza 3).

Hipotezy były oparte na następujących założeniach:

1. IE sprzyja efektywnej regulacji emocji (ponieważ zarządzanie emocjami jest jedną ze zdolności IE)

2. Skuteczna regulacja emocji to regulacja elastyczna

3. Szeroki repertuar strategii jest jedną ze składowych ERE.

\section{MetodA}

\section{Osoby badane}

W badaniu uczestniczyło 180 osób (141 kobiet i 39 mężczyzn). Ze względu na znaczące braki odpowiedzi w Teście inteligencji emocjonalnej (TIE) $\mathrm{z}$ analiz wykluczonych zostało 45 osób i analizowane były dane pochodzące od 135 uczestników (105 kobiet, 30 mężczyzn). Większość tych osób to uczniowie i studenci w wieku 18-40 lat $(M=23)$. Rekrutacja uczestników odbywała się drogą mailową za pośrednictwem poczty studenckiej oraz zaproszeń umieszczonych na Facebooku. 


\section{Procedura i narzędzia}

Procedura. Badanie miało charakter indywidualny, anonimowy i przeprowadzone było w Internecie (w Formularzach Google i na Research.net). Uczestnicy zostali zaproszeni przez e-maile studenckie, a także przez zaproszenia umieszczone na grupach studentów na Facebooku. Badanie (Formularze Google) rozpoczynało się od strony $\mathrm{z}$ informacjami wstępnymi (o celu badania: „sposoby radzenia sobie z emocjami” oraz jego przebiegu) i ogólną instrukcją. Uczestnicy otrzymali także informacje o ochronie danych osobowych i byli poproszeni o zaznaczenie odpowiedniego pola, jeśli zgadzają się na udział w badaniu. Na następnej stronie uczestnicy wpisywali kod, który składał się z trzech pierwszych liter nazwiska panieńskiego matki i trzech ostatnich cyfr własnego numeru telefonu. Podanie kodu było konieczne, by połączyć wyniki uczestnika $\mathrm{z}$ tego formularza $\mathrm{z}$ wynikami TIE, który był wypełniany na platformie Research.net. Następnie respondenci zostali poproszeni o podanie płci (kobieta, mężczyzna, nie chcę określać), roku urodzenia i dyscypliny studiów. Potem pojawiły się pytania Kwestionariusza strategii regulacji emocji (QERS) i Kwestionariusza trudności w regulacji emocji (DERS). Na ostatniej stronie Formularza Google zamieszczona była prośba o wypełnienie jeszcze jednego testu na innej platformie (Research.net). Respondenci zostali poproszeni o otwarcie linku do drugiej platformy w nowej zakładce przeglądarki i kliknięcie „wyślij” w Formularzu Google. Link przeniósł ich do ostatniej części badania: TIE. Na pierwszej stronie tej platformy respondenci musieli wpisać swój kod (taki sam jak w pierwszej części badania) oraz podać płeć i wiek. Następnie przechodzili do wypełnienia testu. Całe badanie trwało około 45 minut.

\section{Narzędzia badawcze.}

Ankieta strategii regulacji emocji (KSRE). Ankieta została stworzona przez zespół pod kierunkiem Doroty Kobylińskiej, działający na Wydziale Psychologii Uniwersytetu Warszawskiego. Składała się ona z dwóch części: A i B. Na początku zamieszone były następujące informacje: „W zależności od sytuacji różni ludzie stosują różne sposoby radzenia sobie z pojawiającymi się emocjami. Nie ma sposobów dobrych lub złych. Interesuje nas, jakich sposobów Ty używasz w celu poprawy nastroju czy poradzenia sobie z trudnymi czy nieadekwatnymi w danej chwili emocjami. Przeczytaj poniższe opisy różnych sposobów radzenia sobie z emocjami i zaznacz swoje odpowiedzi na poniższych skalach. 
Gdy spotyka mnie coś, co wzbudza moje emocje i chcę nad nimi zapanować to...".

Dalej następowały pozycje dotyczące różnych sposobów radzenia sobie z emocjami. Część A zawierała 25 pozycji opisujących różne strategie regulacji emocji. Uczestnicy zaznaczali, na ile zgadzają się z danym twierdzeniem na 7-stopniowej skali $(1$ - zdecydowanie się nie zgadzam; 4 - nie mam zdania; 7 - zdecydowanie się zgadzam), oceniając, czy radzą sobie $\mathrm{z}$ emocjami w określony sposób. Przykładowe pozycje to: „Staram się zobaczyć sytuację w lepszym świetle oraz traktuję ją jako okazję do nauki” lub „Szukam ukojenia w Bogu/religii - modlę się i/lub medytuję". Jako szerokość repertuaru strategii traktowałyśmy liczbę strategii zaznaczonych jako stosowane przez badanych, czyli takich, gdzie na skali zaznaczono cyfrę większą lub równą 5, co wskazywało na stosowanie danej strategii. W tym przypadku nie było dla nas istotne, do jakiego stopnia badani daną strategię stosują. Część B składała się z pytań dotyczących efektywności każdego ze sposobów radzenia sobie. Po każdej pozycji z części A zadawano pytanie z części B (tak aby najpierw uczestnicy odpowiedzieli, czy zgadzają się z tym, że używają określoną strategię, a następnie określili, jak skuteczna jest ta strategia, jeśli ją stosują). Jako wskaźnik skuteczności stosowanych strategii traktowana była średnia ocen skuteczności dla tych strategii, które uczestnik zaznaczył jako stosowane, natomiast jako wskaźnik skuteczności strategii adaptacyjnych - średnia ocen skuteczności dla tych strategii, które uznajemy za adaptacyjne zgodnie $\mathrm{z}$ wcześniejszymi badaniami (Aldao, Jazaieri, Goldin, Gross, 2014; Aldao, Nolen-Hoeksema, 2012; Gross, John, 2003).

ASRE została skonstruowana na podstawie teorii regulacji emocji Grossa (2015a; Gross, Thompson, 2007) oraz koncepcji poznawczej regulacji emocji (Garnefski i in., 2001). Uwzględniłyśmy w narzędziu strategie regulacji emocji opisane $w$ tych dwóch podejściach. Na przykład były to strategie regulacji emocji z pięciu grup według Grossa. I tak z grupy wyboru sytuacji - „wybieram sytuacje/ludzi, które/którzy wywołują we mnie pożądane emocje”; z grupy modyfikacji sytuacji - „energicznie przystępuję do działania szukając dodatkowych sposobów, aby rozwiązać problem”; z grupy kierowania uwagą „staram się zobaczyć sytuację w lepszym świetle oraz traktuję ją jako okazję do nauki”; z grupy zmiany interpretacji sytuacji - „przyzwyczajam się do myśli, że tak się stało, uczę się z tym żyć akceptując uczucia, jakie ta sytuacja we mnie wzbudziła” oraz z grupy zmiana reakcji - „mimo, iż odczuwam emocje, nie daję nic po sobie poznać". 
Test inteligencji emocjonalnej (TIE). Test (Orzechowski, Śmieja, Beauvale, 2007) oparty jest na opisanym powyżej modelu teoretycznym Mayera, Saloveya i Caruso (Mayer, Salovey, 1993; Mayer i in., 2004). Składa się z czterech podskal mierzących percepcję, rozumienie, asymilację i zarządzanie emocjami. TIE składa się z dwóch części: pierwsza zawiera 15, a druga 12 pozycji. Pozycje te opisują sytuacje życiowe o charakterze społeczno-emocjonalnym, a badani proszeni są o ocenę skuteczności podjętych przez bohaterów sytuacji działań lub odczuwanych przez nich emocji. W części pierwszej (dotyczącej podskal percepcji i rozumienia emocji), zadaniem uczestników jest ocena tego, jak czuje się osoba w opisanej sytuacji. Zadaniem uczestników w drugiej części, odnoszącej się do asymilacji i zarządzania emocjami, jest wskazanie najodpowiedniejszego działania, jakie postać z opowieści powinna podjąć, aby rozwiązać problem. Podobnie jak w pierwszej części, uczestnicy oceniają adekwatność każdej z alternatyw, odpowiadając na 5-stopniowej skali Likerta, gdzie: 1 - odpowiedź zdecydowanie nietrafna; 2 - odpowiedź nietrafna; 3 odpowiedź równie trafna, jak nietrafna; 4 - odpowiedź trafna; 5 - odpowiedź zdecydowanie trafna.

\section{WYNIKI}

W celu sprawdzenia związku między szerokością repertuaru strategii a IE przeprowadzono analizę korelacji. Wyniki wskazują, zgodnie z naszą hipotezą, że istnieje słaba pozytywna korelacja między IE a liczbą stosowanych przez uczestników strategii $(r=0,18 ; p=0,018)$. Im wyższa IE, tym większą liczbę wykorzystywanych strategii deklarowali uczestnicy.

Jeśli chodzi o podskale testu IE, liczba strategii korelowała istotnie pozytywnie z percepcją $(r=0,17 ; p=0,021)$. Korelacje z podskalami rozumienia, asymilacji i zarządzania emocjami kształtowały się na poziomie tendencji statystycznych (odpowiednio: $r=0,14 ; p=0,059 ; r=0,13$; $p=0,068$ i $r=0,14$; $p=0,058)$.

Następnie podzieliliśmy wszystkie strategie na adaptacyjne i nieadaptacyjne (bądź mniej adaptacyjne), opierając się na wcześniejszych badaniach (Aldao i in., 2014; Aldao, Nolen-Hoeksema, 2012; John, Gross, 2004). Wyniki wykazały istotną pozytywną korelację IE z liczbą stosowanych przez uczestników deklarowanych strategii adaptacyjnych $(r=0,26 ; p=0,001)$ oraz brak korelacji $\mathrm{z}$ liczbą strategii nieadaptacyjnych. Także trzy podskale testu EI korelowały 
dodatnio $\mathrm{z}$ liczbą strategii adaptacyjnych: percepcja $(r=0,24 ; p=0,003)$, asymilacja $(r=0,22 ; p=0,005)$ oraz zarządzanie emocjami $(r=0,26 ; p=0,001)$.

Sprawdzono także związek IE z ogólną deklarowaną przez uczestników efektywnością wykorzystywanych strategii. Wyniki pokazały słabą, dodatnią korelację $(r=0,02 ; p=0,016)$. Im wyższy poziom IE u uczestników, tym większą deklarowali skuteczność strategii regulacji emocji, które stosują. Jeśli chodzi o podskale testu IE, efektywność korelowała istotnie dodatnio z percepcją $(r=0,17 ; p=0,022)$ i zarządzaniem emocjami $(r=0,23 ; p=0,003)$.

\section{Dyskusja}

Celem opisanego badania było sprawdzenie, czy rozpiętość repertuaru stosowanych strategii regulacji emocji koreluje z IE. Zgodnie z hipotezą 1, okazało się, że IE pozytywnie koreluje z deklarowaną liczbą strategii stosowanych przez uczestników, co sugeruje, że osoby z wyższym poziomem IE mają szerszy repertuar strategii - stosują więcej strategii regulacji emocji - niż osoby $\mathrm{z}$ niższym poziomem IE. Ponadto IE korelowała dodatnio z deklarowaną liczbą stosowanych przez uczestników strategii adaptacyjnych, co potwierdziło hipotezę 2 . Im wyższy poziom EI, z tym większej liczby adaptacyjnych strategii regulacji emocji korzystają uczestnicy. Poziom IE korelował także pozytywnie z efektywnością strategii stosowanych przez uczestników, zgodnie z przewidywaniami zawartymi w hipotezie 3 . Wszystkie korelacje były raczej słabe, co może wskazywać, że IE jest tylko jednym z mechanizmów przewidujących ERE i prawdopodobnie wiele innych czynników może wiązać się z rozpiętością repertuaru strategii czy skutecznością regulacji emocji. Chociaż wyniki są zgodne z naszymi przewidywaniami i zachęcają do dalszych badań, badanie ma kilka ograniczeń.

Przede wszystkim nasze narzędzie do pomiaru rozpiętości repertuaru strategii oraz jej skuteczności miało charakter deklaratywny. Z pewnością niektóre strategie są społecznie postrzegane jako bardziej adaptacyjne niż inne. Strategie takie jak stosowanie używek (np. picia alkoholu) lub obwinianie się są prawdopodobnie postrzegane jako mniej społecznie akceptowalne niż inne strategie, takie jak zmiana interpretacji sytuacji wzbudzającej emocje. Zatem świadomi tego uczestnicy mogli używać autoprezentacji, co mogło skutkować niedoszacowaniem stosowania pewnych strategii (uważanych za mniej adaptacyjne czy akceptowalne) i przeszacowaniem korzystania $z$ innych 
(uważanych za bardziej adaptacyjne lub akceptowalne). Szczególnie mogło to dotyczyć osób z wyższym poziomem IE, które mogą być bardziej świadome ogólnej skuteczności poszczególnych strategii i w związku z tym, deklarować wykorzystywanie większej liczby strategii, które niejako „powinny” stosować (tych uznawanych za bardziej adaptacyjne czy akceptowalne). Również subiektywna ocena efektywności wykorzystywanych strategii regulacji emocji mogła być zakłócona - np. badani mogli zdawać sobie sprawę, że strategie, których używają, "powinny” być skuteczne (w przeciwnym razie, po co ich używać) i mogli przeceniać ich skuteczność.

Po drugie, szerokość repertuaru strategii mierzono jako ogólną liczbę strategii zaznaczonych przez badanych jako stosowane. Nie mamy pewności jak często, na jaką skalę i w jakich sytuacjach uczestnicy faktycznie stosują te deklarowane strategie, ani też $\mathrm{w}$ jakim stopniu stosowanie strategii jest efektywne. Ocena repertuaru strategii, na przykład metodą EMA (Ecological Momentary Assessment), mogłaby dostarczyć bardziej rzetelnych danych na temat strategii rzeczywiście stosowanych w życiu codziennym i ich skuteczności (Haines i in., 2016). Jest także możliwe, że uczestnicy używają innych sposobów regulowania swoich emocji niż te wymienione w naszym narzędziu. Co więcej, repertuar strategii, mimo iż postrzegany jest jako ważny dla ERE, nie musi być wcale kluczowy. Bonnano i Burton (2014), oprócz dostępności repertuaru strategii regulacyjnych, wymieniają dwa inne elementy ERE: wrażliwość na kontekst i reakcje na informacje zwrotne. Również inni badacze argumentują, że w celu osiągnięcia sukcesu regulacyjnego (Aldao i in., 2015; Doré i in., 2016) należy stosować strategie z uwzględnieniem kontekstu sytuacyjnego (np. intensywność emocji - Sheppes i in., 2014) i/lub cech osobowości osoby, która reguluje emocje (Kobylińska, Marchlewska, 2017). Nasze badanie nie pozwalało na uchwycenie tych aspektów ERE. Planujemy zająć się tymi zagadnieniami w kolejnych badaniach, opracowując eksperymenty, w których mogłybyśmy manipulować kontekstem sytuacyjnym, a następnie obserwować skuteczność stosowania instruowanych strategii regulacji emocji, przy uwzględnieniu wybranych różnic indywidualnych, np. cech osobowości. Należy również pamiętać, że wcześniejsze badania pokazały, że strategie należące do różnych grup opisanych w modelu Grossa (2014, 2015a, 2015b) są powiązane $\mathrm{z} I E \mathrm{w}$ różny sposób. Na przykład stosowanie tłumienia było negatywnie skorelowane z IE, podczas gdy stosowanie ponownej oceny pozytywnie (Gross, 1998a; Gross, John, 2003). Co więcej, badacze zwracają uwagę, że być może osoby z wysokim IE często i efektywnie stosują strategie 
poprzedzające wystąpienie reakcji emocjonalnej, a tym samym nie potrzebują stosować strategii zorientowanych na reakcję, które z założenia są mniej skuteczne (Peña-Sarrionandia, Mikolajczak, Gross, 2015; Śmieja, 2018). W naszym badaniu taki mechanizm mógł skutkować mniejszą ogólną liczbą stosowanych strategii u osób o wysokim poziomie IE (ponieważ część ze strategii należała do grupy tych zorientowanych na reakcję).

Znajduje to pewne odzwierciedlenie $w$ naszych wynikach, ponieważ korelacja IE z liczbą strategii adaptacyjnych jest wyższa niż z ogólną liczbą stosowanych strategii.

Mimo że związek między ERE a IE z pewnością istnieje (co znajduje pewne potwierdzenie także w naszych wynikach), przeprowadzone przez nas badanie jest zbyt podstawowe, aby wyjaśnić złożoność tego związku. Do lepszej oceny ERE konieczne byłoby uwzględnienie kontekstu sytuacyjnego i czynników osobowościowych. Dla bardziej rzetelnej weryfikacji ogólnych hipotez o skuteczności ERE i jej związku z EI należałoby przyjąć bardziej obiektywne miary adaptacyjności i efektywności strategii. Pomimo że nasze hipotezy zostały potwierdzone i wyniki wskazują na pozytywny związek IE z (1) rozpiętością repertuaru strategii, zwłaszcza z liczbą strategii adaptacyjnych stosowanych przez uczestników oraz (2) skutecznością stosowanych strategii, zdajemy sobie sprawę, że nasz pomiar wykorzystywania i efektywności strategii nie jest wolny od ograniczeń i powinien zostać udoskonalony w przyszłych badaniach.

Stosowanie wielu różnych strategii nie wystarczy, aby skutecznie regulować emocje, ale jest to jeden z czynników, który pomaga osiągnąć sukces regulacyjny. Wyniki naszego badania mogą stanowić zachętę do dalszego badania złożoności ERE.

\section{BiBLIOGRAFIA}

Aldao, A., Jazaieri, H., Goldin, P. R., Gross, J. J. (2014). Adaptive and maladaptive emotion regulation strategies: Interactive effects during CBT for social anxiety disorder. Journal of Anxiety Disorders, 28(4), 382-389. https://doi.org/10.1016/j. janxdis.2014.03.005

Aldao, A., Nolen-Hoeksema, S. (2012). When are adaptive strategies most predictive of psychopathology? Journal of Abnormal Psychology, 121(1), 276-281. https://doi. org/10.1037/a0023598 
Aldao, A., Sheppes, G., Gross, J. J. (2015). Emotion regulation flexibility. Cognitive Therapy and Research, 39(3), 263-278. https://doi.org/10.1007/s10608-014-9662-4

Bar-On, R. (1997). Bar-On Emotional Quotient Inventory: Technical manual. Toronto: Multi-Health Systems.

Bonanno, G. A., Burton, C. L. (2014). Regulatory flexibility: An individual differences perspective on coping and emotion regulation. Psychological Science, 8(6), 591-612. https://doi.org/10.1177/1745691613504116

Campos, J. J., Frankel, C. B., Camras, L. (2004). On the nature of emotion regulation. Child Development, 75(2), 377-394. https://doi.org/10.1111/j.1467-8624.2004.00681.x

Cheng, C. (2001). Assessing coping flexibility in real-life and laboratory settings: A multimethod approach. Journal of Personality and Social Psychology, 80(5), 814-833. https://doi.org/10.1037/0022-3514.80.5.814

Doré, B. P., Silvers, J. A., Ochsner, K. N. (2016). Toward a personalized science of emotion regulation. Social and Personality Psychology Compass, 10(4), 171-187. https://doi.org/10.1111/spc3.12240

Fernández-Berrocal, P., Extremera, N. (2006). Emotional intelligence: A theoretical and empirical review of its first 15 years of history. Psicothema, 18(Suppl), 7-12.

Garnefski, N., Kraaij, V., Spinhoven, P. (2001). Negative life events, cognitive emotion regulation and emotional problems. Personality and Individual Differences, 30(8), 1311-1327. https://doi.org/10.1016/S0191-8869(00)00113-6

Goleman, D. (1997). Inteligencja emocjonalna. Poznań: Media Rodzina of Poznań.

Gross, J. J. (1998a). Antecendent- and response-focused emotion regulation: Divergent consequences for experience, expression, and physiology. Journal of Personality and Social Psychology, 74(1), 224-237. https://doi.org/10.1037/0022-3514.74.1.224

Gross, J. J. (1998b). The emerging field of emotion regulation: An integrative review. Review of General Psychology, 2(3), 271-299. https://doi.org/10.1037/1089-2680.2.3.271

Gross, J. J. (2002). Emotion regulation: Affective, cognitive and social consequences. Psychophisiology, 39(3), 281-291. https://doi.org/10.1017/S0048577201393198

Gross, J. J. (2014). Emotion regulation: Conceptual and empirical foundations. W: J. J. Gross (red.), Handbook of emotion regulation (s. 3-20). Nowy Jork: Guilford Press.

Gross, J. J. (2015a). Emotion regulation: Current status and future prospects. Psychological Inquiry, 26(1), 1-26. https://doi.org/10.1080/1047840X.2014.940781

Gross, J. J. (2015b). The extended process model of emotion regulation: Elaborations, applications, and future directions. Psychological Inquiry, 26(1), 130-137. https:// doi.org/10.1080/1047840X.2015.989751 
Gross, J. J., John, O. P. (2003). Individual differences in two emotion regulation processes: Implications for affect, relationships, and well-being. Journal of Personality and Social Psychology, 85(2), 348-362. https://doi.org/10.1037/0022-3514.85.2.348

Gross, J. J., Thompson, R. A. (2007). Emotion regulation: Conceptual foundations. W: J. J. Gross (red.), Handbook of emotion regulation (s. 3-21). Nowy Jork: Guilford Press.

Haines, S. J., Gleeson, J., Kuppens, P., Hollenstein, T., Ciarrochi, J., Labuschange, I., ..., Koval, P. (2016). The wisdom to know the difference, strategy-situation fit in emotion regulation daily life is associated with well-being. Psychological Science, 27(12), 1651-1659. https://doi.org/10.1177/0956797616669086

Kashdan, T. B., Rottenberg, J. (2010). Psychological flexibility as a fundamental aspect of health. Clinical Psychology Review, 30(7), 865-878. https://doi.org/10.1016/j. cpr.2010.03.001

Kobylińska, D., Marchlewska, M. (2017). Orientacja na działanie a regulacja emocji. Psychologia - Etologia - Genetyka, 34, 25-42.

Kobylińska, K., Kusev, P. (2019). Flexible emotion regulation: How situational demands and individual differences influence the effectiveness of regulatory strategies. Frontiers in Psychology, 10, 72. https://doi.org/10.3389/fpsyg.2019.00072

Koole, S. L., Coenen, L. H. M. (2007). Implicit self and affect regulation: Effects of action orientation and subliminal self priming in an affective priming task. Self and Identity, 6(2-3), 118-136. https://doi.org/10.1080/15298860601118835

Koole, S. L., Webb, T. L., Sheeran, P. L. (2015). Implicit emotion regulation: Feeling better without knowing why. Current Opinion in Psychology, 3, 6-10. https://doi. org/10.1016/j.copsyc.2014.12.027

Kuhl, J. (1992). A theory of self-regulation: Action versus state orientation, self-discrimination, and some applications. Applied Psychology: An International Review, 41(2), 97-129. https://doi.org/10.1111/j.1464-0597.1992.tb00688.x

Larsen, R. J., Prizmic, Z. (1999). Affect regulation. W: T. Dalgleish, M. J. Power (red.), Handbook of cognition and emotion (s. 40-57). Chichester: John Wiley and Sons.

Mayer, J. D., Caruso, D. R., Salovey, P. (2016). The ability model of emotional intelligence: Principles and updates. Emotion Review, 8(4), 290-300. https://doi. org/10.1177/1754073916639667

Mayer, J. D., Salovey, P. (1993). The intelligence of emotional intelligence. Intelligence, 17(4), 433-442. https://doi.org/10.1016/0160-2896(93)90010-3

Mayer, J. D., Salovey, P., Caruso, D. (2004). Emotional intelligence: Theory, findings and implications. Psychological Inquiry, 15(3), 197-215. https://doi.org/10.1207/ s15327965pli1503_02 
Mayer, J. D., Salovey, P., Caruso, D. R. (2008). Emotional intelligence: New ability or eclectic traits? American Psychologist, 63(6), 503-517. https://doi.org/10.1037/0003-066X.63.6.503

McRae, K., Ciesielski, B., Gross, J. J. (2012). Unpacking cognitive reappraisal: goals, tactics and outcomes. Emotion, 12(2), 250-255.

McRae, K., Heller, S. M., John, O. P., Gross, J. J. (2011). Context-dependent emotion regulation: Suppression and reappraisal at the Burning Man festival. Basic and Applied Social Psychology, 33(4), 346-350. https://doi.org/10.1080/01973533.2011.614170

Ochsner, K. N., Gross, J. J. (2008). Cognitive emotion regulation: Insights from social cognitive and affective neuroscience. Current Directions in Psychological Science, 17(2), 153-158. https://doi.org/10.1111/j.1467-8721.2008.00566.x

Ochsner, K. N., Gross, J. J. (2014). The neural bases of emotion and emotion regulation: A valuation perspective. W: J. J. Gross (red.), Handbook of emotion regulation (s. 23-42). Nowy Jork: Guilford Press.

Pavot, W. P., Diener, E., Fujita, F. (1990). Extraversion and happiness. Personality and Individual Differences, 11(12), 1299-1306. https://doi.org/10.1016/01918869(90)90157-M

Peña-Sarrionandia, A., Mikolajczak, M., Gross, J. J. (2015). Integrating emotion regulation and emotional intelligence traditions: A meta-analysis. Frontiers in Psychology, 6, 160. https://doi.org/10.3389/fpsyg.2019.02610

Salovey, P., Detweiler-Bedell, B. T., Detweiler-Bedell, J. B., Mayer. D. (2010). Emotional intelligence. W: M. Lewis, J. M. Haviland- Jones, L. Feldman Barrett L. (red.), Handbook of emotions (s. 533-547). Nowy Jork: Guilford Press.

Salovey, P., Mayer, J. D. (1990). Emotional intelligence. Imagination, Cognition, and Personality, 9(3), 185-211. https://doi.org/10.2190/DUGG-P24E-52WK-6CDG

Sheppes, G., Scheibe, S., Suri, G., Gross, J. J. (2011). Emotion-regulation choice. Psychological Science, 22(11), 1391-1396. https://doi.org/10.1177/0956797611418350

Sheppes, G., Scheibe, S., Suri, G., Radu, P., Blechert, J., Gross, J. J. (2014). Emotionregulation choice: A conceptual framework and supporting evidence. Journal of Experimental Psychology, 143(1), 163-181. https://doi.org/10.1037/a0030831

Śmieja, M. (2018). W związku z inteligencją emocjonalną. Rola inteligencji emocjonalnej $w$ relacjach społecznych i związkach intymnych. Kraków: Wydawnictwo Uniwersytetu Jagiellońskiego.

Śmieja, M., Orzechowski, J. (2008). Inteligencja emocjonalna: fakty, mity, kontrowersje. W: M. Śmieja, J. Orzechowski (red.), Inteligencja emocjonalna: fakty, mity, kontrowersje (s. 19-45). Warszawa: Wydawnictwo Naukowe PWN.

Śmieja, M., Orzechowski, J., Beauvale, A. (2007). TIE - Test Inteligencji Emocjonalnej. Studia Psychologiczne, 45(1), 19-31. 
Śmieja, M., Orzechowski, J., Stolarski, M. (2014). TIE: An ability test of emotional intelligence. PLoS One, 9(7), e103484. https://doi.org/10.1371/journal.pone.0103484

Tamir, M. (2009). Differential preferences for happiness: Extraversion and traitconsistent emotion regulation. Journal of Personality, 77(2), 447-470. https://doi. org/10.1111/j.1467-6494.2008.00554.x

Tamir, M. (2016). Why do people regulate their emotions? A taxonomy of motives in emotion regulation. Personality and Social Psychology Review, 20(3), 199-222. https://doi.org/10.1177/1088868315586325

Thompson, R. A. (1994). Emotion regulation: A theme in search of definition. Monographs of the Society for Research in Child Development, 59(2-3), 25-52. https:// doi.org/10.2307/1166137

Troy, A. S., Shallcross, A. J., Mauss, I. B. (2013). A person-by-situation approach to emotion regulation: Cognitive reappraisal can either help or hurt, depending on the context. Psychological Science, 24(12), 2505-2514. https://doi.org/10.1177/0956797613496434

Westphal, M., Seivert, N. H., Bonanno, G. A. (2010). Expressive flexibility. Emotion, 10(1), 92-100. https://doi.org/10.1037/a0018420

Wojciszke, B. (2003). Skale regulacji nastroju. W: M. Marszał-Wiśniewska, T. Klonowicz, M. Fajkowska-Stanik (red.), Psychologia różnic indywidualnych (s. 163-179). Gdańsk: Gdańskie Wydawnictwo Psychologiczne. 
Kamilla BARGIEL-MATUSIEWICZ iD https://orcid.org/0000-0002-9467-2267 Wydział Psychologii, Uniwersytet Warszawski

SZYMON MAKUŁA iD https://orcid.org/0000-0001-6421-2748

KRZYSZTOF SZYMANEK (iD https://orcid.org/0000-0002-2817-2651

KrZYSZTOF A. WIECZOREK iD https://orcid.org/0000-0002-9352-1512

Wydział Humanistyczny, Uniwersytet Śląski

URSZUlA ZiĘTALEWICZ (iD) https://orcid.org/0000-0002-9405-3415

Studium Psychologii Zdrowia, Warszawski Uniwersytet Medyczny

EWA PISUlA (iD https://orcid.org/0000-0002-7458-5043

Wydział Psychologii, Uniwersytet Warszawski

\section{Struktura i własności psychometryczne Skali optymizmu poznawczego - badania pilotażowe}

\section{The structure and psychometric properties of the Cognitive Optimism Scale - a pilot study}

Sposób cytowania: Bargiel-Matusiewicz, K., Makuła, S., Szymanek, K., Wieczorek, K. A., Ziętalewicz, U., Pisula, E. (2021). Inteligencja emocjonalna a rozpiętość repertuaru strategii regulacji emocji i ich efektywność. W: M. Huflejt-Łukasik, A. Pluta (red.), Mechanizmy psychologiczne i społeczne warunkujace formułowanie ocen oraz podejmowanie działań (s. 59-75). Warszawa: Wydawnictwo Liberi Libri. https://doi. org/10.47943/lib.9788363487553.rozdzial03 


\section{Streszczenie}

Celem artykułu jest prezentacja nowego narzędzia - Skali optymizmu poznawczego. Narzędzie służy do pomiaru dwóch konstruktów. Pierwsza podskala dotyczy Społecznego optymizmu poznawczego. Mierzy ona stopień zaufania do możliwości poznawczych człowieka (jako ludzkości), reprezentowanych przez badania naukowe oraz związane z tym zaufanie do osiąganych w badaniach naukowych rezultatów. Społeczny optymizm poznawczy wiąże się z przekonaniem, że stosowanie naukowych narzędzi umożliwia zdobywanie coraz większej i dokładniejszej wiedzy o świecie, stopniowe rozwiązywanie wielu ważnych dla ludzkości pytań i problemów. Druga podskala dotyczy Indywidualnego optymizmu poznawczego. Mierzy ona stopień przekonania o posiadaniu zdolności samodzielnego, logicznego i niezawodnego myślenia, w tym rozstrzygania złożonych kwestii o specjalistycznym charakterze. W badaniu udział wzięło $N=1029$ studentów polskich uczelni wyższych w wieku 18-39 lat. Wyniki potwierdziły dwuczynnikową strukturę narzędzia oraz wysoką rzetelność pomiaru. W celu poprawy własności psychometrycznych dokonano skrócenia o cztery pozycje oryginalnej wersji skali użytej w badaniu.

Słowa kluczowe: optymizm poznawczy, racjonalność poznania

\section{Abstract}

The aim of the article is to present a new scientific tool - the Cognitive Optimism Scale. The tool is used to measure two constructs. The first subscale concerns Social Cognitive Optimism. It measures the degree of trust in human cognitive abilities (as humanity), represented by scientific research, and the related confidence in the results achieved in scientific research. Social cognitive optimism is associated with the belief that the use of scientific tools enables the acquisition of more and more accurate knowledge about the world, gradual solving of many 
questions and problems important to humanity. The second subscale concerns Individual Cognitive Optimism. It measures the degree of confidence in having the ability to think independently, logically and reliably, including resolving complex specialist issues. $N=1029$ students of Polish universities aged 18-39 participated in the study. The results confirmed the two-factor structure of the scale and high measurement reliability. In order to improve the psychometric properties, the original version of the scale used in the study was shortened by four items.

Keywords: cognitive optimism, rationality of cognition

Omawiana w niniejszym artykule Skala optymizmu poznawczego służy do pomiaru dwóch cech, które zdaniem autorów mają istotne znaczenie dla tworzenia racjonalnego systemu przekonań. Podskala pierwsza - Społeczny optymizm poznawczy - mierzy, (1) po pierwsze, stopień zaufania do możliwości poznawczych człowieka, reprezentowanych przez badania naukowe, i (2) po drugie - związane z tym zaufanie do osiąganych w badaniach naukowych rezultatów. Społeczny optymizm poznawczy wiąże się także z przekonaniem, że stosowanie naukowych narzędzi umożliwia zdobywanie coraz większej i dokładniejszej wiedzy o świecie oraz stopniowe rozwiązywanie wielu ważnych dla ludzkości pytań i problemów.

Druga podskala - Indywidualny optymizm poznawczy - mierzy stopień zaufania jednostki do własnych władz poznawczych, zdolności do samodzielnego, logicznego i niezawodnego myślenia, autonomicznego i niezależnego od autorytetów, w tym autorytetu nauki. Zmienna ta dotyczy także przekonania o zdolności samodzielnego rozstrzygania złożonych kwestii, nawet tych, które mają specjalistyczny charakter.

Wysokie wyniki osiągane na tej skali wskazują na ograniczoną racjonalność wynikającą z braku rozeznania co do struktury wiedzy i natury narzędzi poznawczych człowieka. Wyniki analiz, które prezentowane są w niniejszym artykule, potwierdzają hipotezę o pozytywnej korelacji między indywidualnym optymizmem poznawczym a tendencją do wyznawania nieracjonalnych przekonań. 
Można przewidywać, że cechy konstytutywne dla racjonalnego, krytycznego myślenia będą sprzyjać wyższym wynikom w zakresie społecznego optymizmu poznawczego i niższym w zakresie indywidualnego optymizmu poznawczego. Prawdopodobnie wysoki indywidualny optymizm poznawczy zwiększa podatność na manipulację, gdyż jednostka łatwiej ulega iluzji poprawności logicznej pseudonaukowego przekazu, nie zdając sobie sprawy z własnego braku kompetencji. Natomiast wysoki poziom optymizmu społecznego przyczynia się prawdopodobnie do sceptycyzmu wobec twierdzeń niezgodnych z nauką głównego nurtu.

Rola optymizmu poznawczego ma istotne znaczenie z perspektywy wyjaśniania mechanizmów odpowiedzialnych za obserwowane współcześnie w kulturze Zachodu takie zjawiska, jak: deprecjacja nauki, podważanie jej pozycji społecznej, niski poziom świadomości metodologicznej i umiejętności krytycznego myślenia (Coady, 2012; Keyes, 2004; Lewandowsky, Ecker, Cook, 2017; Webb, Jirodka, 2017).

Era masowej komunikacji, demokracji komunikacyjnej i postprawdy stanowi poważne zagrożenie dla kultury zachodniej i jej podstawowych wartości, dlatego ważne jest zrozumienie struktury i uwarunkowań zaufania do nauki oraz świadomości metodologicznej. Jak zauważa Nichols (2017), kluczowym problemem dla zjawiska, które określił mianem death of expertise, jest nie tyle ignorancja, bo ta jest zjawiskiem, które zawsze w jakimś zakresie było obecne w historii naszej cywilizacji, lecz wrogie nastawienie do rzetelnej naukowej wiedzy.

Niektórzy badacze wskazują na ryzyko, iż w przyszłości powszechne uznanie wobec pewnych teorii wyjaśniających rzeczywistość nie będzie wynikać z rzetelnych badań naukowych, lecz będzie stanowić efekt dynamiki na tzw. rynku opinii w mediach społecznościowych (opinion market on social media; Lewandowsky i in., 2017; Webb, Jirodka, 2017). Media te stwarzają dogodne warunki dla manipulacji, umożliwiając jednocześnie rozpowszechnianie dezinformacji na dużą skalę (Hecht, 2018; Lewandowsky i in., 2017). Dezinformacja nie musi zresztą mieć charakteru działania zamierzonego, dyktowanego wyłącznie złą wolą. W mediach obecne są również nieświadome zniekształcenia czy błędne interpretacje danych wynikające $\mathrm{z}$ braku wiedzy bądź z deficytów w zakresie świadomości metodologicznej (Kozak, 2018; Picciotto, 2019).

Wyniki dotychczasowych badań nie przynoszą klarownej odpowiedzi na pytanie, dlaczego niektórzy ludzie akceptują naukowe rozstrzygnięcia i pokładają zaufanie w nauce, podczas gdy inni wybierają wyjaśnienia pseudonaukowe lub zdroworozsądkowe (Lobato, Zimmerman, 2018). Ekspansja teorii spiskowych, 
różnych form pseudonauki oraz ruchy kontestujące wyniki badań naukowych stanowią przejaw rosnącej popularności i atrakcyjności nieracjonalnych form postrzegania i wyjaśniania rzeczywistości (Abalakina-Paap, Stephan, Craig, Gregory, 1999; Douglas, Sutton, Cichocka, 2017; Drinkwater, Dagnall, Parker, 2012; Furnham, 2013; Lewandowsky i in., 2017).

Za podważanie zaufania do naukowego obrazu świata odpowiada również w pewnym stopniu medialna ofensywa pseudonauki, z którą mamy do czynienia przede wszystkim w Internecie. Zasadnicze znaczenie ma zrozumienie przyczyn, dla których pseudonauka tak skutecznie konkuruje z nauką na rynku opinii. Jak twierdzi wielu badaczy (np. Hecht, 2018; Picciotto, 2019; Tsipursky, Votta, Roose, 2018), zrozumienie pseudonauki jest równie ważne, jak jej obalenie.

Proponowany przez autorów konstrukt - optymizm poznawczy, może być pomocny w opisie i analizie przedstawionej powyżej problematyki zaufania do nauki.

W celu oceny właściwości psychometrycznych oraz trafności Skali optymizmu poznawczego wykonano analizę czynnikową oraz poddano analizie korelację wyników z mentalnością spiskową (Bruder, Haffke, Neave, Nouripanah, Imhoff, 2013), prawicowym autorytaryzmem (Funke, 2005; Grzesiak-Feldman, 2012) oraz potrzebą poznawczego domknięcia (Kossowska, Hanusz, Trejtowicz, 2012; Webster, Kruglanski, 1994).

\section{Metoda}

\section{Uczestnicy}

W badaniu uczestniczyło $N=1029$ osób - studentów polskich uczelni wyższych w wieku $18-39$ lat $(M=22 ; S D=3) ; 92,5 \%$ z nich to kobiety. Uczestnicy wypełniali kwestionariusze zamieszczone w serwisie qualtrics.com. Nie otrzymywali oni wynagrodzenia za udział w badaniu.

\section{Narzędzia badawcze}

W badaniu użyto oryginalnej wersji Skali optymizmu poznawczego składającej się z 21 pozycji. Po wykonaniu analiz własności psychometrycznych 
skali została ona skrócona do 17 pytań (zob. Załącznik). Umożliwia pomiar dwóch zagadnień: indywidualnego optymizmu poznawczego, czyli poziomu wiary w możliwość jednostki do samodzielnego poznania prawdy o świecie (8 pozycji), i ogólnego optymizmu poznawczego polegającego na wierze w naukę i jej moc odpowiadania na ważne dla ludzkości pytania (9 pozycji). Respondenci ustosunkowują się do stwierdzeń na 7-stopniowej skali Likerta (od 0 - nie zgadzam się w ogóle, do 6 - w petni się zgadzam). Wskaźnik rzetelności skali alfa Cronbacha dla ogólnego optymizmu poznawczego wynosi 0,77, a dla indywidualnego optymizmu naukowego 0,70 .

Kwestionariusz mentalności spiskowej (Conspiracy Mentality Questionnaire; Bruder i in., 2013; polska adaptacja: Stefaniak, Winiewski, 2019) składa się z 5 pytań i mierzy tendencję do wiary w teorie konspiracyjne, dostarczające alternatywnych wyjaśnień wydarzeń, dla których istnieje już racjonalne, ogólnie przyjęte wytłumaczenie. Osoby badane oceniają, w jakim stopniu zgadzają się ze stwierdzeniami na 11-stopniowej skali procentowej, gdzie $0 \%$ oznacza, że badany nie zgadza się ze stwierdzeniem, natomiast $100 \%$, że zgadza się z nim całkowicie. Rzetelność skali w badaniu własnym wynosi $\alpha=0,83$.

Trójwymiarowa skala prawicowego autorytaryzmu (Right-Wing Authoritarianism; Funke, 2005; Grzesiak-Feldman, 2012) służy do pomiaru cech autorytarnych i konserwatywnych. Składa się z 12 zagadnień, do których badani ustosunkowują się za pomocą 5-stopniowej skali Likerta od 1 -zdecydowanie się nie zgadzam, do 5 - zdecydowanie się zgadzam. Rzetelność skali w badaniu własnym wynosi $\alpha=0,77$.

Skrócona skala potrzeby poznawczego domknięcia (Webster, Kruglanski, 1994; zob. też: Kossowska i in., 2012) służy do pomiaru potrzeby do pozyskiwania sprawdzonej, wiarygodnej wiedzy, redukującej poczucie niepewności poznawczej. Skala składa się z 15 pozycji i zawiera 5 podskal: Nietolerancja wieloznaczności, Preferowanie porządku, Preferowanie przewidywalności, Zamkniętość umysłowa oraz Zdecydowanie. Uczestnicy badania odnoszą się do prezentowanych twierdzeń za pomocą 6-stopniowej skali (od $1-z d e c y$ dowanie się nie zgadzam, do 6 - całkowicie się zgadzam). Rzetelność skali dla wyniku ogólnego w badaniu własnym wyniosła $\alpha=0,66$. 


\section{WYNIKI}

W tabeli 1 zaprezentowano statystyki opisowe dla dwóch podskal - indywidualnego optymizmu poznawczego i ogólnego optymizmu poznawczego.

U mężczyzn zaobserwowano wyższe niż u kobiet wyniki dla skal: Indywidualny optymizm poznawczy $\left(U=47596 ; p=0,001 ; M_{\text {dn_kobiety }}=20\right.$, $\left.M_{\text {dn_męiczýnin }}=22\right)$ oraz społeczny optymizm poznawczy $(U=41154 ; p<0,001$; $\left.M_{\text {dn_kobiety }}=30, M_{\text {dn_męiccyźni }}=34\right)$.

Tabela 1

Statystyki opisowe

\begin{tabular}{lccccc}
\hline \multicolumn{1}{c}{ Podskala } & $\boldsymbol{M}$ & Mediana & SD & Skośność & Kurtoza \\
\hline $\begin{array}{l}\text { Indywidualny optymizm } \\
\text { poznawczy }\end{array}$ & 20,56 & 21 & 5,75 & $-0,02$ & 0,72 \\
$\begin{array}{l}\text { Społeczny optymizm } \\
\text { poznawczy }\end{array}$ & 31,04 & 31 & 8,81 & 0,13 & $-0,45$ \\
\hline
\end{tabular}

\section{Analiza czynnikowa}

W wyniku przeprowadzenia eksploracyjnej analizy czynnikowej uzyskano rozwiązanie dwuczynnikowe. Wykres osypiska został przedstawiony na rysunku 1. Dwa czynniki wyjaśniają 31,6\% wariancji. Tabela 2 zawiera wartości ładunków czynnikowych dla rozwiązania dwuczynnikowego. Zastosowano metodę wyodrębniania czynników - głównych składowych z rotacją varimax. Analiza korelacji między pozycją a skalą wskazuje, że wartość wskaźnika dla zdecydowanej większości pytań przekracza 0,20 , co jest akceptowalną wartością. 


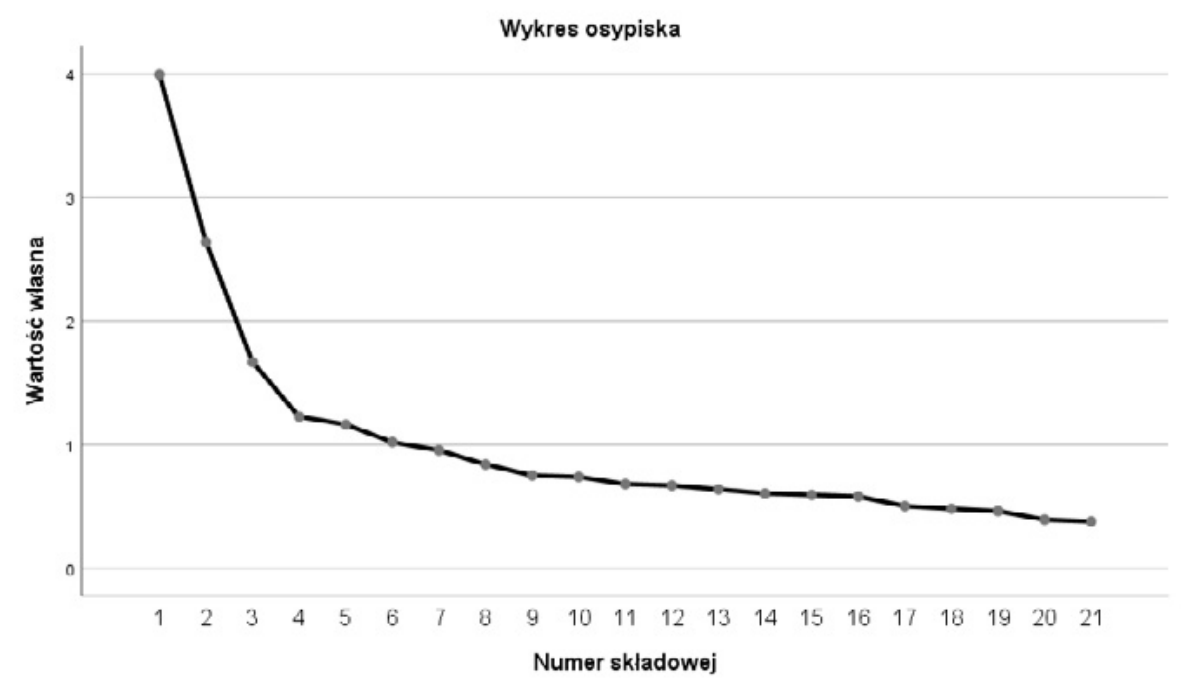

Rysunek 1. Wykres osypiska eksploracyjnej analizy czynnikowej pozycji Skali optymizmu poznawczego.

Tabela 2

Ładunki czynnikowe oraz wskaźniki korelacji między pozycjq a skalq

\begin{tabular}{|c|c|c|c|}
\hline \multirow{2}{*}{ Numer pozycji } & \multicolumn{2}{|c|}{ Składowa } & \multirow{2}{*}{$\begin{array}{c}\text { Wskaźnik korelacji pozycja } \\
\text { - skala }\end{array}$} \\
\hline & 1 & 2 & \\
\hline 1 & 0,58 & 0,06 & 0,41 \\
\hline 2 & 0,44 & $-0,31$ & 0,24 \\
\hline 3 & 0,19 & 0,26 & 0,12 \\
\hline 4 & 0,66 & $-0,18$ & 0,54 \\
\hline 5 & 0,41 & $-0,37$ & 0,28 \\
\hline 6 & 0,68 & $-0,28$ & 0,69 \\
\hline 7 & 0,45 & $-0,20$ & 0,31 \\
\hline 8 & 0,65 & $-0,02$ & 0,41 \\
\hline 9 & 0,48 & $-0,17$ & 0,37 \\
\hline 10 & 0,72 & 0,12 & 0,65 \\
\hline 11 & $-0,01$ & 0,66 & 0,36 \\
\hline
\end{tabular}

Ciąg dalszy tabeli na następnej stronie 
Ciąg dalszy tabeli z poprzedniej strony

\begin{tabular}{|c|c|c|c|}
\hline \multirow{2}{*}{ Numer pozycji } & \multicolumn{2}{|c|}{ Składowa } & \multirow{2}{*}{$\begin{array}{c}\text { Wskaźnik korelacji pozycja } \\
\text { - skala }\end{array}$} \\
\hline & 1 & 2 & \\
\hline 12 & 0,31 & 0,43 & 0,42 \\
\hline 13 & $-0,34$ & 0,53 & 0,36 \\
\hline 14 & $-0,14$ & 0,55 & 0,38 \\
\hline 15 & $-0,09$ & 0,68 & 0,46 \\
\hline 16 & 0,35 & 0,19 & 0,47 \\
\hline 17 & 0,47 & 0,21 & 0,27 \\
\hline 18 & 0,01 & 0,53 & 0,55 \\
\hline 19 & $-0,04$ & 0,06 & 0,19 \\
\hline 20 & $-0,13$ & 0,45 & 0,38 \\
\hline 21 & 0,15 & 0,55 & 0,31 \\
\hline
\end{tabular}

\section{Własności psychometryczne}

Spójność wewnętrzna została oceniona przez obliczenie alfy Cronbacha. Wynosi ona 0,70 dla podskali Indywidualny optymizm poznawczy oraz 0,77 dla podskali Społeczny optymizm poznawczy.

Korelacje między Skalq optymizmu poznawczego a Kwestionariuszem mentalności spiskowej, Skalq potrzeby poznawczego domknięcia oraz Trójwymiarowq skalq prawicowego autorytaryzmu

Podskala Indywidualny optymizm poznawczy była słabo pozytywnie skorelowana $\mathrm{z}$ mentalnością spiskową $(r=0,38 ; p<0,001)$ i prawicowym autorytaryzmem $(r=0,28 ; p<0,001)$ oraz z potrzebą poznawczego domknięcia $(r=0,13 ; p<0,001)$, co oznacza, że osoby, które w mniejszym stopniu wierzą w naukę niż we własne zdolności poznawania zjawisk, mają większą skłonność do wiary w teorie spiskowe, przejawiają większe nasilenie cech autorytarnych i konserwatywnych oraz mają większą potrzebę redukcji niepewności poznawczej. Podskala Społeczny optymizm poznawczy słabo negatywnie skorelowana była z mentalnością spiskową $(r=-0,33 ; p<0,001)$ i prawicowym autorytaryzmem $(r=-0,28 ; p<0,001)$, co oznacza, że osoby, które silniej wierzą w naukę, mają 
mniejszą skłonność do wiary w teorie spiskowe oraz przejawiają mniejsze nasilenie cech autorytarnych i konserwatywnych. Podskala ta była także bardzo słabo i pozytywnie skorelowana z potrzebą poznawczego zamknięcia $(r=$ 0,$07 ; p<0,040$ ). Wielkość wskaźnika korelacji wskazuje jednak na praktyczny brak związku między tymi dwoma zmiennymi i prawdopodobnie wynika z wielkości próby.

\section{Dyskusja}

Wyniki potwierdziły dwuczynnikową strukturę proponowanego narzędzia oraz wysoką rzetelność pomiaru jego skalami. Dodatkowo analiza korelacji pomiędzy skalami a mentalnością spiskową (Bruder i in., 2013) oraz prawicowym autorytaryzmem (Funke, 2005; Grzesiak-Feldman, 2012) wskazuje na trafność narzędzia.

Mentalność spiskowa została uwzględniona, gdyż jest ona istotnym elementem pseudonaukowej narracji (Bruder i in., 2013; Coady, 2012; Drinkwater i in., 2012; Goertzel, 2010). W jej obrębie propagowane są między innymi tezy o niedopuszczaniu do publikowania w czasopismach naukowych artykułów prezentujących opinie niekorzystne dla pewnej określonej grupy interesariuszy posiadających silne wpływy w środowisku naukowym. Wśród przykładów tego typu sytuacji jest propagowanie opinii, że globalne ocieplenie to mit sprokurowany przez naukowców w celu wyłudzenia funduszy na badania (Goertzel, 2010). Indywidualny optymizm poznawczy był pozytywnie skorelowany z mentalnością spiskową $(r=0,38 ; p<0,001)$, z którą ujemnie skorelowany był społeczny optymizm poznawczy $(r=-0,33 ; p<0,001)$. W związku z uzyskanym wynikiem można stwierdzić, że kierunek współzmienności pomiędzy skalami proponowanego narzędzia a mentalnością spiskową jest zgodny z oczekiwaniami i potwierdza trafność Skali optymizmu poznawczego.

Prawicowy autorytaryzm został uwzględniony w niniejszych badaniach ze względu na wyraźny teoretyczny związek między nim a optymizmem poznawczym. Wydaje się mianowicie, że specyficzny sposób postrzegania rzeczywistości społecznej, skłonność do akceptacji konwencjonalnych, ogólnie uznanych i społecznie akceptowanych zasad i prawd przez osoby wykazujące wysoki poziom autorytaryzmu może być powiązany z ich sposobem kształtowania przekonań, do którego nawiązuje Skala optymizmu poznawczego. Wykazanie korelacji pomiędzy obiema tymi zmiennymi jest więc istotne dla trafności teoretycznej skali. 
Od lat '40 XX wieku badacze poszukują związku między cechami osobowości a postawami społeczno-politycznymi, tym, jak ludzie myślą i jakie ideologie wyznają, jaki kreują obraz świata społecznego. $Z$ tego pola badań pochodzi pojęcie osobowości autorytarnej stworzone w latach ' 40 przez filozofa i socjologa Theodora Adorno wraz z zespołem współpracowników (Adorno, 2010). Badacze poszukiwali psychologicznego wyjaśnienia rozkwitu faszyzmu w Niemczech lat 1933-1945, stawiając tezę o rozpowszechnieniu w tym kraju pewnego zestawu cech osobowości przekładającego się na wytworzenie społecznych i politycznych postaw sprzyjających budowie faszystowskiej, antydemokratycznej indywidualności. Adorno i jego zespół doszukiwali się źródeł postaw faszystowskich w rygorystycznym wychowaniu dzieci. Jako charakterystyczne dla ukształtowanej w toku takiego wychowania osobowości autorytarnej Adorno wskazuje m.in. konwencjonalizm, czyli bezkrytyczne przywiązanie do tradycyjnych norm i zasad, agresja przeciw ludziom łamiącym te zasady, zachowującym się niekonwencjonalnie i „nienormalnie”, postrzeganie własnej grupy społecznej w sposób wyidealizowany, zaś innych grup jako obcych, gorszych. Kolejne cechy to skłonność do przesądów i przypisywania mocy sprawczej zewnętrznym ukrytym czynnikom - również nadprzyrodzonym. Jednostka taka szuka autorytetów - ludzi postawionych w hierarchii władzy wyżej od niej, którzy wiedzą lepiej, co i jak robić. Obok niechęci do samopoznania i analizy własnych stanów psychicznych, a także myśli i emocji innych ludzi, jednym z elementów osobowości autorytarnej ma być projektywność, czyli przypisywanie innym ludziom własnych negatywnych uczuć, ukrytych pragnień i motywów.

Osoby, które cechuje wysoki poziom prawicowego autorytaryzmu przejawiają silne uprzedzenia, etnocentryzm, nacjonalizm, wrogość wobec mniejszości seksualnych, mają też skłonności do błędnego interpretowania rzeczywistości i bezkrytycznej akceptacji danych i argumentów potwierdzających ich przekonania (Altemeyer, 1981, 2006). Liczne badania wskazują na związek między autorytaryzmem a skłonnością do wiary w spiski (Grzesiak-Feldman, 2016).

$\mathrm{W}$ prezentowanych $\mathrm{w}$ niniejszym rozdziale badaniach indywidualny optymizm poznawczy wiązał się pozytywnie z prawicowym autorytaryzmem $(r=0,28 ; p<0,001)$, co oznacza, że osoby, które w mniejszym stopniu wierzą $\mathrm{w}$ naukę niż we własne zdolności poznawania zjawisk, przejawiają większe nasilenie cech autorytarnych i konserwatywnych.

Społeczny optymizm poznawczy był ujemnie związany z prawicowym autorytaryzmem $(r=-0,28 ; p<0,001)$, co oznacza, że im większe zaufanie do nauki, tym mniejsze nasilenie cech autorytarnych i konserwatywnych. 
Potrzeba domknięcia poznawczego została uwzględniona, gdyż autorzy oczekiwali, że może być ona powiązana $\mathrm{z}$ optymizmem poznawczym (dodatnio $\mathrm{z}$ indywidualnym, a ujemnie ze społecznym). Potrzeba domknięcia poznawczego jest bowiem definiowana jako dążenie do formułowania klarownych, ostatecznych opinii (Kruglanski, Webster, 1996; Roets, Van Hiel, 2007; Schumpe i in., 2017; Webster, Kruglanski, 1994). Wysoki wskaźnik potrzeby domknięcia poznawczego świadczy o tendencji do budowania uproszczonych obrazów rzeczywistości w związku z poszukiwaniem klarownej i pewnej wiedzy. Niejednoznaczne sytuacje są często traktowane jako źródło zagrożenia (Kossowska i in., 2012; Kruglanski, Orehek, Dechesne, Pierro, 2009).

Uzyskane wyniki wykazały jednak tylko bardzo słaby związek pomiędzy indywidualnym optymizmem poznawczym a potrzebą poznawczego domknięcia $(r=0,13 ; p<0,001)$.

Kierunek tej współzmienności jest zgodny z oczekiwaniami, aczkolwiek $\mathrm{z}$ uwagi na siłę związku wnioski $\mathrm{w}$ tym zakresie należy formułować $\mathrm{z}$ dużą ostrożnością. Dodatkowo społeczny optymizm poznawczy był także bardzo słabo pozytywnie związany z potrzebą poznawczego domknięcia $(r=0,07$; $p<0,04)$, choć wielkość wskaźnika korelacji wskazuje w zasadzie na brak związku między tymi dwoma zmiennymi. W związku z powyższym, należy wziąć pod uwagę, że relacja pomiędzy oboma rodzajami optymizmu poznawczego a potrzebą domknięcia poznawczego może mieć bardziej złożony charakter niż pierwotnie oczekiwano, a ustalenie jej natury wymaga dalszych pogłębionych analiz. Warto kontynuować badania $\mathrm{w}$ tym zakresie również z uwagi na fakt, że inni autorzy wskazują na niejednoznaczną rolę potrzeby domknięcia poznawczego $\mathrm{w}$ kwestii m.in. decyzji powiązanych $\mathrm{z}$ naukami medycznymi. Wykazano na przykład, że im silniejsza potrzeba poznawczego domknięcia, tym mniejsza gotowość do poddania się szczepieniu na H1N1 (Cole i in., 2015), podczas gdy w innych badaniach potrzeba domknięcia poznawczego sprzyjała podejmowaniu badań kontrolnych pod kątem raka szyjki macicy (Eiser, Cole, 2002).

Należy zwrócić uwagę na pewne ograniczenia prezentowanych rezultatów. Badanie zostało przeprowadzone drogą internetową, wzięli w nim udział wyłącznie studenci wyższych uczelni, z których zdecydowaną większość stanowiły kobiety. Co prawda rozpiętość wieku była dosyć duża: 18-39 lat, jednak tylko 20 osób spośród wszystkich badanych miało 30 lub więcej lat, więc dla wyników ma to stosunkowo małe znaczenie. Obecnie, według danych GUS (https://bdl.stat.gov.pl, dostęp: 23.09.2020), studenci stanowią w Polsce 
około połowy osób w wieku 19-24. Grupa badawcza nie może być uznana za reprezentatywną dla ludności Polski. Mimo to potwierdzenie w tej grupie wysuniętych przez nas hipotez korelacyjnych może być poczytane za ich częściowe uzasadnienie. Oczywiście warto, aby w dalszych badaniach optymizm poznawczy został poddany analizie w populacjach o bardziej zróżnicowanym wieku oraz wykształceniu $\mathrm{z}$ uwzględnieniem również wpływu innych cech demograficznych, jak np. płeć czy wielkość miejsca zamieszkania.

\section{Bibliografia}

Abalakina-Paap, M., Stephan, W. G., Craig, T., Gregory, W. L. (1999). Beliefs in conspiracies. Political Psychology, 20(3), 637-647. https://doi.org/10.1111/0162-895X.00160

Adorno, T. W. (2010). Osobowość autorytarna. Warszawa: Wydawnictwo Naukowe PWN.

Altemeyer, B. (1981). Right-wing authoritarianism. Winnipeg: University of Manitoba Press.

Altemeyer, B. (2006). The authoritarians. Winnipeg: University of Manitoba Press.

Bruder, M., Haffke, P., Neave, N., Nouripanah, N., Imhoff, R. (2013). Measuring individual differences in generic beliefs in conspiracy theories across cultures: Conspiracy Mentality Questionnaire. Frontiers in Psychology, 4, 225. https://doi. org/10.3389/fpsyg.2013.00225

Coady, D. (2012). What to believe now: Applying epistemology to contemporary issues. Oxford: Wiley-Blackwell.

Cole, A. P., Gill, J. M., Fletcher, K. D., Shivers, C. A., Allen, L. C., Mwendwa, D. T. (2015). Understanding African American college students' H1N1 vaccination decisions. Health Psychology, 34(12), 1185. https://doi.org/10.1037/hea0000232

Douglas, K. M., Sutton, R. M., Cichocka, A. (2017). The psychology of conspiracy theories. Current Directions in Psychological Science, 26(6), 538-542. https://doi. org/10.1177/0963721417718261

Drinkwater, K., Dagnall, N., Parker, A. (2012). Reality testing, conspiracy theories, and paranormal beliefs. Journal of Parapsychology, 76(1), 57-77.

Eiser, J. R., Cole, N. (2002). Participation in cervical screening as a function of perceived risk, barriers and need for cognitive closure. Journal of Health Psychology, 7(1), 99-105. https://doi.org/10.1177/1359105302007001657

Funke, F. (2005). The dimensionality of right-wing authoritarianism: Lesson from the dilemma between theory and measurement. Political Psychology, 26(2), 195-218. https://doi.org/10.1111/j.1467-9221.2005.00415.x 
Furnham, A. (2013). Commercial conspiracy theories: A pilot study. Frontiers in Psychology, 4, 379. https://doi.org/10.3389/fpsyg.2013.00379

Goertzel, T. (2010). Conspiracy theories in science. EMBO Reports, 11(7), 493-499. https://doi.org/10.1038/embor.2010.84

Grzesiak-Feldman, M. (2012). Prawicowy autorytaryzm oraz orientacja na dominację społeczną jako predyktory różnych form myślenia spiskowego. Psychologia Społeczna, 7 1(20), 48-63.

Grzesiak-Feldman, M. (2016). Psychologia myślenia spiskowego. Warszawa: Wydawnictwa Uniwersytetu Warszawskiego.

Hecht, D. K. (2018). Pseudoscience and the pursuit of truth. W: A. B. Kaufman, J. C. Kaufman (red.), Pseudoscience: The conspiracy against science (s. 3-20). Cambridge: The MIT Press.

Keyes, R. (2004). The post-truth era. Dishonesty and deception in contemporary life. Nowy Jork: St. Martin's Press.

Kossowska, M., Hanusz, K., Trejtowicz, M. (2012). Skrócona wersja Skali Potrzeby Poznawczego Domknięcia. Dobór pozycji i walidacja skali. Psychologia Społeczna, 7(1), 89-99.

Kozak, A. (2018). Understanding pseudoscience vulnerability through epistemological development, critical thinking, and science literacy. W: A. B. Kaufman, J. C. Kaufman (red.), Pseudoscience: The conspiracy against science (s. 223-238). Cambridge: The MIT Press.

Kruglanski, A. W., Orehek, E., Dechesne, M., Pierro, A. (2009). Three decades of lay epistemics: The why, how, and who of knowledge formation. European Review of Social Psychology, 20(1), 146-191. https://doi.org/10.1080/10463280902860037

Kruglanski, A. W., Webster, D. M. (1996). Motivated closing of the mind: „Seizing” and „freezing”. Psychological Review, 103(2), 263-283. https://doi.org/10.1037/0033295X.103.2.263

Lewandowsky, S., Ecker, U. K. H., Cook, J. (2017). Beyond misinformation: Understanding and coping with the 'post-truth' era. Journal of Applied Research in Memory and Cognition, 6(4), 353-369. https://doi.org/10.1016/j.jarmac.2017.07.008

Lobato, E. J. C., Zimmerman, C. (2018). The psychology of (pseudo)science: Cognitive, social, and cultural factors W: A. B. Kaufman, J. C. Kaufman (red.), Pseudoscience: The conspiracy against science (s. 21-43). Cambridge: The MIT Press.

Nichols, T. (2017). The death of expertise. The campaign against established knowledge and why it matters. Oxford: University Press USA.

Picciotto, R. (2019). Is evaluation obsolete in a post-truth world? Evaluation and Program Planning, 73, 88-96. https://doi.org/10.1016/j.evalprogplan.2018.12.006 
Roets, A., Van Hiel, A. (2007). Separating ability from need: Clarifying the dimensional structure of the Need for Closure Scale. Personality and Social Psychology Bulletin, 33(2), 266-280. https://doi.org/10.1177/0146167206294744

Schumpe, B. M., Brizi, A., Giacomantonio, M., Panno, A., Kopetz, C., Kosta, M., Mannetti, L. (2017). Need for cognitive closure decreases risk taking and motivates discounting of delayed rewards. Personality and Individual Differences, 107, 66-71. https://doi.org/10.1016/j.paid.2016.11.039

Stefaniak, A., Winiewski, M. (2019). Uprzedzenia $w$ Polsce 2017. Oblicza przemocy międzygrupowej. Warszawa: Liberi Libri.

Tsipursky, G., Votta, F., Roose, K. (2018). Fighting fake news and post-truth politics with behavioral science: The Pro-Truth Pledge. Behavior and Social Issues, 27, 47-70. https://doi.org/10.5210/bsi.v27i0.9127

Webb, H., Jirotka, M. (2017). Nuance, societal dynamics, and responsibility in addressing misinformation in the post-truth era: Commentary on Lewandowsky, Ecker, and Cook. Journal of Applied Research in Memory and Cognition, 6(4), 414-417. https://doi.org/10.1016/j.jarmac.2017.10.001

Webster, D. M., Kruglanski, A. W. (1994). Individual differences in need for cognitive closure. Journal of Personality and Social Psychology, 67(6), 1049-1062. https://doi. org/10.1037/0022-3514.67.6.1049

\section{ZAŁĄCZNIK 1}

Skala optymizmu poznawczego - wersja oryginalna

1. Nauka potrafi wyjaśnić każde zjawisko.

2. Naukowe teorie są tylko teoriami, bardzo często fałszywymi.

3. Wynalezienie lekarstwa na raka nastąpi najdalej za 10 lat.

4. Na świecie jest wiele rzeczy, których nauka nigdy nie wyjaśni.

5. Wiedza ludzka, wbrew pozorom, niewiele posunęła się do przodu przez ostatnie tysiąclecia.

6. Najważniejsze prawa, które rządzą światem, pozostaną dla umysłu ludzkiego na zawsze niepojęte.

7. Nigdy nie dowiemy się, skąd się wzięło dobro i zło.

8. Jest tylko kwestią czasu rozwiązanie zagadki powstania świata.

9. Do tej pory, naukowcom udało się zrozumieć wiele zagadnień ważnych dla naszego codziennego życia.

10. Ludzkość jest w stanie rozwiązać każdą zagadkę wszechświata. 
11. Umiejętność samodzielnego myślenia daje mi więcej, niż kierowanie się opiniami jakichkolwiek ekspertów.

12. Zwykle potrafię rozstrzygnąć, która ze stron w sporach ekonomicznych, politycznych, medycznych itp. ma rację, a która się myli.

13. Oficjalna nauka niechętnie zmienia zdanie, nawet wobec mocnych dowodów, że się myli.

14. Nie wierzę w żadne argumenty naukowców, zanim sam(a) ich starannie nie przemyślę.

15. Moja zdolność do logicznego myślenia jest dla mnie dużo ważniejsza od podręcznikowej wiedzy na jakiś temat.

16. Jeżeli zależy mi na zrozumieniu jakiegoś zagadnienia, to jestem $\mathrm{w}$ stanie zdobyć potrzebną wiedzę.

17. Każdego dnia coraz lepiej rozumiem otaczający mnie świat.

18. Zwykle nie muszę zbyt daleko wchodzić w szczegóły problemu, by wyrobić sobie rozsądną opinię.

19. Dopuszczam myśl, że w niektórych ważnych kwestiach mogą mieć rację osoby o poglądach odmiennych niż moje.

20. Nie muszę czytać mnóstwa książek na jakiś temat, by wyrobić sobie pogląd.

21. Bardzo często udaje mi się dostrzec sedno zagadnienia, którego nie widzą inni. 


\section{ZAŁĄCZNIK 2}

\section{Skala optymizmu poznawczego - wersja skrócona}

\begin{tabular}{|c|c|}
\hline Podskala & Pozycja \\
\hline SOP & 1. Nauka potrafi wyjaśnić każde zjawisko. \\
\hline SOP & 2. Naukowe teorie są tylko teoriami, bardzo często fałszywymi. \\
\hline SOP & 4. Na świecie jest wiele rzeczy, których nauka nigdy nie wyjaśni. \\
\hline SOP & 6. Najważniejsze prawa, które rządzą światem, pozostaną dla umysłu ludzkiego na zawsze niepojęte. \\
\hline SOP & 7. Nigdy nie dowiemy się, skąd się wzięło dobro i zło. \\
\hline SOP & 8. Jest tylko kwestią czasu rozwiązanie zagadki powstania świata. \\
\hline SOP & 9. Do tej pory, naukowcom udało się zrozumieć wiele zagadnień ważnych dla naszego codziennego życia. \\
\hline SOP & 10. Ludzkość jest w stanie rozwiązać każdą zagadkę wszechświata. \\
\hline IOP & $\begin{array}{l}\text { 11. Umiejętność samodzielnego myślenia daje mi więcej, niż kierowanie się opiniami jakichkolwiek } \\
\text { ekspertów. }\end{array}$ \\
\hline IOP & $\begin{array}{l}\text { 12. Zwykle potrafię rozstrzygnąć, która ze stron w sporach ekonomicznych, politycznych, medycznych itp. } \\
\text { ma rację, a która się myli. }\end{array}$ \\
\hline IOP & 13. Oficjalna nauka niechętnie zmienia zdanie, nawet wobec mocnych dowodów, że się myli. \\
\hline IOP & 14. Nie wierzę w żadne argumenty naukowców, zanim sam(a) ich starannie nie przemyślę. \\
\hline IOP & $\begin{array}{l}\text { 15. Moja zdolność do logicznego myślenia jest dla mnie dużo ważniejsza od podręcznikowej wiedzy na } \\
\text { jakiś temat. }\end{array}$ \\
\hline SOP & 17. Każdego dnia coraz lepiej rozumiem otaczający mnie świat. \\
\hline IOP & 18. Zwykle nie muszę zbyt daleko wchodzić w szczegóły problemu, by wyrobić sobie rozsądną opinię. \\
\hline IOP & 20. Nie muszę czytać mnóstwa książek na jakiś temat, by wyrobić sobie pogląd. \\
\hline IOP & 21. Bardzo często udaje mi się dostrzec sedno zagadnienia, którego nie widzą inni. \\
\hline
\end{tabular}

Adnotacja. SOP - Społeczny optymizm poznawczy, IOP - Indywidualny optymizm poznawczy. 

CZĘŚĆ II. MECHANIZMY I SPOSOBY SAMOREGULACJI A PODEJMOWANIE DECYZJI I DZIAŁAŃ 

Dorota RutKowsKa iD https://orcid.org/0000-0002-4789-7578

MAgDAlENA GRZESIK (iD) https://orcid.org/0000-0003-2660-8236

Wydział Psychologii, Uniwersytet Warszawski

\section{Efekt sformułowania w decyzjach ryzykownych a ukierunkowania regulacyjne}

\section{The framing effect in risky decisions and self-regulatory orientations}

Sposób cytowania: Rutkowska, D., Grzesik, M. (2021). Efekt sformułowania w decyzjach ryzykownych a ukierunkowania regulacyjne. W: M. Huflejt-Łukasik, A. Pluta (red.), Mechanizmy psychologiczne i społeczne warunkujace formułowanie ocen oraz podejmowanie działań (s. 79-100). Warszawa: Wydawnictwo Liberi Libri. https://doi. org/10.47943/lib.9788363487553.rozdzial04

Przygotowanie artykułu było finansowane $\mathrm{z}$ funduszy Wydziału Psychologii Uniwersytetu Warszawskiego na badania statutowe DSM 1117/2015.

Korespondencję dotyczącą artykułu prosimy kierować do Magdaleny Grzesik, Wydział Psychologii, Uniwersytet Warszawski, ul. Stawki 5/7, 00-183 Warszawa, e-mail: magdalena.grzesik@psych.uw.edu.pl 


\section{Streszczenie}

Efekt sformułowania w decyzjach ryzykownych (Tversky, Kahneman, 1981) polega na zmianie proporcji wyborów opcji pewnej i ryzykownej o tej samej wartości oczekiwanej w zależności od domeny, w której podejmowana jest decyzja. W domenie zysku decydenci wykazują awersję do ryzyka, wybierając opcję pewną, zaś w domenie straty wykazują skłonność do podejmowania ryzyka, wybierając opcję ryzykowną. W dwóch eksperymentach $(N=46$ i $N=51)$ sprawdzano, czy występowanie efektu sformułowania ma związek z promocyjnym i prewencyjnym ukierunkowaniem regulacyjnym (Higgins, 1997, 1998). Jako scenariusz decyzyjny wykorzystano zmodyfikowany problem azjatyckiej choroby, a uczestników proszono nie tylko o wybór jednej opcji, ale również o dokonanie odrębnych ocen zarówno opcji pewnej, jak i ryzykownej. Efekt sformułowania uzyskano w wyborach osób badanych, ale zaobserwowano inny wzór różnic między ocenami opcji w grupach, w których przy pomocy manipulacji wzbudzono ukierunkowania promocyjne i prewencyjne. Osoby, u których wzbudzono ukierunkowanie prewencyjne wykazywały zróżnicowanie ocen wyłącznie w domenie zysku, zaś oceny osób, u których wzbudzono ukierunkowanie promocyjne, różniły się istotnie jedynie w domenie straty (Eksperyment I). Uzyskany wzór różnic między ocenami opcji wystąpił jednak wyłącznie u osób o silniejszym ukierunkowaniu prewencyjnym, operacjonalizowanym jako względnie trwała właściwość (Eksperyment II).

Słowa kluczowe: efekt sformułowania, ukierunkowania regulacyjne, promocyjne ukierunkowanie regulacyjne, prewencyjne ukierunkowanie regulacyjne

\section{Abstract}

The risky choice framing effect in decision making (Tversky, Kahneman, 1981) consists in the change of the preference between sure and risky options of the same expected value, depending on the domain in 
which the choice is made. In gain domain people tend to be risk averse and choose the sure gain but in loss domain they become risk seeking and reveal the preference for the risky loss. In two experiments $(N=$ 46 and $N=51$ ) we tested whether the effect depends on prevention and promotion self-regulatory orientations (Higgins, 1997, 1998). We used the modified Asian Disease problem as the framed decision scenario but the participants were asked not only to choose one of the options but also to rate each option separately. The framing effect was demonstrated in choices. However, when self-regulatory orientations were induced with the experimental manipulation (Experiment I), promotion-focused and prevention-focused participants revealed differences in their rating patterns. The prevention-focused participants demonstrated differences between the ratings of the options only in gain domain while the ratings of the promotion-focused participants differed only in loss domain. The pattern of the ratings was maintained only for the prevention-focused when individual differences in self-regulatory orientations were measured (Experiment II).

Keywords: framing effect, self-regulatory orientations, self-promotion focus, self-prevention focus

\section{Efekt sformułowania w wyborach ryzykownych}

Efekt sformułowania w wyborach ryzykownych (risky choice framing effect) jest zniekształceniem poznawczym, które polega na odwróceniu proporcji wyborów opcji pewnej i ryzykownej w zależności od przedstawienia problemu decyzyjnego w kategoriach zysków lub strat (Tversky, Kahneman, 1981; por. Sokołowska, 2005; Tyszka, 2010). Kiedy skutki decyzji przedstawione są jako zyski, u decydentów występuje skłonność do unikania ryzyka (risk aversion), która prowadzi do preferencji opcji pewnego zysku w stosunku do opcji ryzykownego zysku. Kiedy skutki decyzji przedstawiane są jako straty, u decydentów pojawia się skłonność do poszukiwania ryzyka (risk seekeing), która prowadzi do preferencji opcji ryzykownej straty w stosunku do opcji pewnej 
straty. Preferencje te występują pomimo identycznej wartości oczekiwanej wszystkich opcji wyboru. Efekt sformułowania w wyborach ryzykownych został opisany przez Amosa Tversky'ego i Daniela Kahnemana w Teorii Perspektywy (Prospect Theory; Kahneman, Tversky, 1979; por. Kahneman, 2012). Teoria Pespektywy jest deskryptywną teorią procesu podejmowania decyzji, która stanowiła odpowiedź na zauważane przez badaczy odstępstwa decydentów od aksjomatycznych reguł racjonalności (Kühberger, 2002): zupełności, przechodniości, ciągłości i niezależności preferencji. Potoczne obserwacje, jak również badania naukowe pokazują, że ludzie często nie potrafią określić spójnie swoich preferencji lub zmieniają je spontanicznie albo pod wpływem innego sformułowania pytania. $Z$ jednej strony powoduje to rozmaite zniekształcenia decyzji, z drugiej strony - warto zwrócić uwagę na pozytywną, adaptacyjną dla podmiotu stronę tej powierzchownej nieracjonalności.

Autorzy Teorii Perspektywy postulują, że proces podejmowania decyzji składa się z dwóch faz: fazy edycji i fazy oceny. W fazie edycji zachodzą dwa procesy. W procesie kodowania decydent weryfikuje, czy konsekwencje danego zdarzenia stanowią dla niego zysk czy stratę względem własnego, subiektywnego punktu odniesienia, a w procesie segregacji oddziela opcje pewne od niepewnych. W fazie oceny decydent dokonuje wyboru opcji o największej subiektywnej wartości. Kluczowym elementem sytuacji decyzyjnej w związku z tym jest punkt odniesienia (reference point), względem którego skutki decyzji oceniane są jako zyski lub jako straty. Jeżeli decydent koduje je jako zyski, mówimy, że podejmuje decyzję $\mathrm{w}$ domenie zysku, jeśli koduje je jako straty, mówimy o podejmowaniu decyzji w domenie straty. Autorzy Teorii Perspektywy wskazali również na znaczenie zasady malejącej wrażliwości oraz awersji do ponoszenia strat. Zasada malejącej wrażliwości stanowi o tym, że każdy kolejny zysk i każda kolejna strata tej samej wartości ma dla decydenta coraz mniejszą wartość subiektywną. Reprezentowane jest to graficznie poprzez charakterystyczne spłaszczenie krzywej użyteczności w miarę oddalania się od punktu odniesienia (Kahneman, Tversky, 1979). Awersja do ponoszenia strat przejawia się tym, że strata o pewnej wartości obiektywnej jest dla człowieka dotkliwsza niż siła pozytywnych doświadczeń spowodowanych zyskiem o tej samej wartości, co z kolei reprezentuje graficznie większy gradient nachylenia krzywej po stronie strat niż po stronie zysków (Kahneman, Tversky, 1979).

Do najczęściej wykorzystywanych w badaniach nad efektem sformułowania scenariuszy decyzyjnych należy problem azjatyckiej choroby (Asian Disease Problem; Tversky, Kahneman, 1981), którego przytoczenie może dobrze zo- 
brazować istotę efektu. W scenariuszu tym występujący w rolach decydentów uczestnicy badań są proszeni o wyobrażenie sobie, że Stany Zjednoczone przygotowują się na wybuch epidemii nieznanej, azjatyckiej choroby, która może doprowadzić do śmierci 600 osób. Informuje się ich także, że zostały zaproponowane dwa alternatywne programy zwalczania tej choroby, oraz że znane są dokładne szacunki naukowe, dotyczące konsekwencji wprowadzenia tych programów. Dalsza część scenariusza różni się w zależności od tego, czy uczestnik badania ma podjąć decyzję w domenie zysku, czy w domenie straty. Jako opcje wyboru w domenie zysku prezentowane są programy opisane w następujący sposób: „Jeśli zostanie wprowadzony program A, 200 osób na pewno przeżyje” oraz „Jeśli zostanie wprowadzony program $\mathrm{B}$, z prawdopodobieństwem $1 / 3$ przeżyje 600 osób, a z prawdopodobieństwem $2 / 3$ nie przeżyje nikt”. W domenie straty zaś jako opcje wyboru prezentowane są programy opisane następująco: „Jeśli zostanie wprowadzony program C, 400 osób na pewno umrze” oraz „Jeśli zostanie wprowadzony program $\mathrm{D}$, z prawdopodobieństwem $1 / 3$ nikt nie umrze, a $\mathrm{z}$ prawdopodobieństwem $2 / 3$ umrze 600 osób". W obydwu domenach uczestnicy badań mają zatem do wyboru opcję pewną oraz ryzykowną. W badaniach Tversky'ego i Kahnemana $72 \%$ osób, którym prezentowano programy w domenie zysku, wybierało opcję pewną, a opcję ryzykowną wybierało $78 \%$ osób, którym prezentowano programy w domenie straty. Podobny wzór wyników, czyli częstsze wybory opcji pewnej w domenie zysku i opcji ryzykownej w domenie straty, był wielokrotnie replikowany z użyciem problemu azjatyckiej choroby i innych scenariuszy (por. Kühberger, 1998, 2002), jednak zdarzało się również, że nie udawało się uzyskać tej charakterystycznej proporcji wyborów.

Przeprowadzone metaanalizy wyników badań nad efektem sformułowania (Kühberger, 1998, 2002; Kühberger, Schulte-Mecklenbeck, Perner, 1999; Steiger, Kühberger, 2018) wskazują m.in. na to, że najsilniejsze efekty uzyskuje się dla scenariuszy o konstrukcji podobnej do problemu azjatyckiej choroby, a największą część wariancji wyborów wyjaśnia domena, choć nie bez znaczenia pozostaje też wartość prawdopodobieństw i wypłat użytych w scenariuszu.

Wiele badań nad efektem sformułowania poświęcono czynnikom warunkującym podatność decydentów na wystąpienie tego zniekształcenia. John Maule (1989) wykazał, że decydenci, którzy ulegają efektowi sformułowania, koncentrują się albo na zysku, albo na stracie, zależnie od sposobu przedstawienia opcji wyboru. Osoby, które okazały się niejako odporne na występowanie efektu, spontanicznie dokonywały przeformułowania opcji 
(re-framing), koncentrując się zarówno na zysku, jak i na stracie. Rezultaty te sugerują, że pewna grupa osób nie ulega zniekształceniu wywoływanemu przez sposób zaprezentowania opcji wyboru. Istotny nurt wśród badań nad uwarunkowaniami efektu sformułowania stanowiły badania, które dotyczyły zależności między występowaniem zniekształcenia a zaangażowaniem poznawczego wysiłku w analizę problemu decyzyjnego (por. Rutkowska, Przybyszewski, 2015). W badaniach tych próbowano wykazać, że występowanie efektu można ograniczyć przez zapowiedź konieczności uzasadnienia swojej decyzji po dokonaniu wyboru (Miller, Fagley, 1991; Takemura, 1994) albo sformułowanie uzasadnienia decyzji przed jej podjęciem (Sieck, Yates, 1997), oraz sytuacyjne wzbudzenie systematycznego przetwarzania informacji (McElroy, Seta, 2003). W innych badaniach (Igou, Bless, 2007) zademonstrowano, jak istotny dla wystąpienia efektu sformułowania jest szerszy kontekst sytuacji decyzyjnej. Efekt występował wtedy, gdy scenariusz dotyczący azjatyckiej choroby prezentowany był jako problem medyczny, ale nie występował, gdy ten sam scenariusz przedstawiano jako problem statystyczny. Rezultat ten interpretowano w świetle założeń Modelu Infuzji Afektu (Forgas, 1995), wskazując na to, że scenariusze decyzyjne mogą prowokować decydentów do korzystania $\mathrm{z}$ innych informacji niż dane $\mathrm{w}$ nich zawarte, $\mathrm{w}$ tym $\mathrm{z}$ reakcji afektywnych wzbudzanych przez opcje wyboru. Dowodów na rolę czynników afektywnych w występowaniu efektu sformułowania dostarczyły badania, w których wykorzystano metody neuroobrazowania i wykazano aktywność struktur neuroanatomicznych odpowiedzialnych za doświadczanie emocji, kiedy badani ulegali efektowi sformułowania (De Martino, Kumaran, Seymour, Dolan, 2006). Kiedy wybory badanych były niezgodne z kierunkiem efektu, aktywność wykazywały struktury odpowiedzialne za zaawansowane operacje poznawcze. Podobne wnioski płyną z także z innych badań, w których wykorzystano neuroobrazowanie (Gonzales, Dana, Koshino, Just, 2005). Pokazano również, że efekt ulega osłabieniu, gdy reinterpretacja scenariusza decyzyjnego wyłączała z niego elementy afektywne (Miu, Crişan, 2011). Na podstawie rezultatów serii eksperymentów Kühberger i Gradl (2013) zauważyli, że efekt sformułowania w wyborach ryzykownych może obrazować nie tyle zmianę awersji do ryzyka w domenie zysku w poszukiwanie ryzyka w domenie straty, ile reakcje ewaluatywne (odczucia oraz oceny), jakie wzbudzają opcje pewnego zysku i pewnej straty. W badaniach poszukiwano także czynników indywidualnych, które redukowałyby podatność na występowanie efektu, przy czym interesowano się przede wszystkim specyfiką funkcjonowania 
poznawczego decydentów, na przykład potrzebą poznania (np. Simon, Fagley, Halleran, 2004) oraz operowaniem Systemu 2 (np. Stanovich, West, 1998). Niektóre badania sugerują jednak, że występowanie efektu sformułowania może być zależne od uwarunkowań osobowościowych. Zademonstrowano, że efekt ten występuje przede wszystkim u osób z niższą skłonnością do podejmowania ryzyka (Huangfu, 2014), a osoby wybierające opcje pewnej i ryzykownej straty różnią się samooceną i tolerancją niepewności (Kornilova, Pavlova, Krasavtseva, Razvalyaeva, 2017). Cechy osobowości okazały się też silniej związane z podejmowaniem ryzyka w celu osiągnięcia zysku, a ryzyko takie chętniej podejmowały osoby otwarte na doświadczenie i ekstrawertyczne. Dla ryzyka podejmowanego w celu zarówno osiągnięcia zysku, jak i uniknięcia straty cechą istotną okazała się neurotyczność: osoby o niższej neurotyczności chętniej podejmowały ryzyko w celu osiągnięcia zysku, a dla uniknięcia straty chętniej ryzykowały osoby o bardziej neurotyczne (Lauriola, Levin, 2001). Rezultaty te sugerują, że badania nad indywidualnymi uwarunkowaniami efektu sformułowania mogą okazać się wartościowym kierunkiem poszukiwań empirycznych. Wśród indywidualnych czynników osobowościowych, które mogą wykazywać związek z podatnością na wpływ sformułowania problemu decyzyjnego, uwagę zwracają ukierunkowania regulacyjne.

\section{Promocyjne i prewencyjne ukierunkowania regulacyjne}

W Teorii Ukierunkowań Regulacyjnych (Regulatory Focus Theory) Edward Tory Higgins $(1997,1998)$ postuluje, że pozytywne stany, do których dąży jednostka, mogą mieć dwojaki charakter: nagrody lub „nie-kary” (reward i non-punishment). Do obu jednostka będzie dążyć, stosując inne strategie: bezpośrednio, czyli minimalizując rozbieżności pomiędzy stanem obecnym a stanem pożądanym, lub niejako pośrednio, czyli maksymalizując rozbieżności pomiędzy stanem obecnym a konkurencyjnymi stanami niepożądanymi. Zgodnie z inną koncepcją Higginsa, Teorią Rozbieżności Ja (Self-Discrepancy Theory; Higgins, 1987), odmienny charakter stanów pozytywnych ma swój początek w odmiennym źródle tych stanów: Ja idealnym i Ja powinnościowym. Ja idealne obejmuje aspiracje, pragnienia i nadzieje jednostki oraz atrybuty, jakie chciałaby posiadać. Ja powinnościowe bierze się z obowiązków i powinności oraz obejmuje atrybuty, które uważamy, że powinniśmy posiadać ze względu na zewnętrzne standardy. Zarówno Ja idealne, jak i Ja powinnościowe 
może stać się źródłem regulacji polegającej na minimalizacji rozbieżności pomiędzy stanem obecnym podmiotu a innymi stanami: stanem idealnym w przypadku Ja idealnego lub stanem wynikającym z postrzeganej powinności w przypadku Ja powinnościowego. Człowiek będzie jednak stosował inne strategie w celu minimalizacji rozbieżności między Ja realnym a Ja idealnym i Ja powinnościowym. Ja idealne kieruje uwagę podmiotu na tzw. cele maksymalne (marzenia, aspiracje, osiągniecia, wzrost, ideały). Podmiot wyczulony jest więc na sygnały tego, czy cel maksymalny udało się osiągnąć oraz dąży do dopasowania (approach match) do celu maksymalnego. Higgins nazywa taką tendencję motywacyjną ukierunkowaniem promocyjnym (self-promotion focus). Sukcesem jest tutaj osiągnięcie stanu pozytywnego, a porażką jego nieosiągnięcie (Bąk, 2008). Ja powinnościowe ukierunkowuje uwagę na tzw. cele minimalne (obowiązki, ochranianie, odpowiedzialność, bezpieczeństwo), co wiąże się z wyczuleniem podmiotu na sygnały, które mogłyby świadczyć o tym, że nie udało się osiągnąć minimum i unikaniem niedopasowania (avoid mismatch) do celu minimalnego. Taką tendencję Higgins nazywa ukierunkowaniem prewencyjnym (self-prevention focus). W przypadku tego ukierunkowania sukcesem jest wypełnienie zobowiązania, niedopuszczenie do stanu negatywnego, a porażką jego wystąpienie (Bąk, 2008). Ukierunkowanie promocyjne wiąże się zatem $\mathrm{z}$ zaspokajaniem potrzeb wzrostu (nurturance needs), ukierunkowanie prewencyjne wiąże się zaś z zaspokajaniem potrzeb bezpieczeństwa (security needs; Higgins, 1997). Ukierunkowanie promocyjne i prewencyjne stanowią dwa odmienne systemy samoregulacji (Bąk, 2008), co oznacza, że podmiot może charakteryzować nie tylko dominacja jednego $\mathrm{z}$ ukierunkowań, ale również wysokie, niskie lub przeciętne natężenie każdego $\mathrm{z}$ nich. Zatem natężenie każdego $\mathrm{z}$ ukierunkowań $\mathrm{z}$ jednej strony stanowi względnie stałą właściwość podmiotu, z drugiej zaś - może być ono stanem wzbudzanym przez sytuację (np. kontekst zadania lub problemu), w której podmiot się znalazł (Higgins, 2002). W badaniach wykazywano występowanie różnic między ukierunkowaniami regulacyjnymi. Zaobserwowano na przykład, że szybkość uczenia się zasad klasyfikacji bodźców była wyższa wśród osób ukierunkowanych promocyjnie, gdy otrzymywały one punkty za poprawne odpowiedzi, a wśród osób ukierunkowanych prewencyjnie, gdy traciły punkty za popełnione błędy (Markman, Baldwin, Maddox, 2005). Ponadto dla osób $\mathrm{z}$ dominującym ukierunkowaniem promocyjnym bardziej przekonujące były komunikaty reklamowe podkreślające korzyści z nabycia danego produktu podczas, gdy dla osób z dominacją ukierunkowania prewencyjnego bardziej 
przekonujące były komunikaty wskazujące, jakich strat można uniknąć, nabywając dany produkt (Aaker, Lee, 2001; Spiegel, Grant-Pillow, Higgins, 2004). Zachowania osób pracujących w trzyosobowych grupach stawały się coraz bardziej spójne, a decyzje grupowe były bardziej ryzykowne, kiedy członkowie grup byli ukierunkowani promocyjnie, a bardziej zachowawcze, kiedy członkowie byli ukierunkowani prewencyjnie (Levine, Higgins, Choi, 2000). Osoby ukierunkowane promocyjnie generowały większą liczbę alternatywnych hipotez na temat prezentowanych na zdjęciach obiektów, podawały więcej powodów swojego zachowania oraz dopuszczały więcej powodów zachowania innych ludzi, podczas gdy osoby ukierunkowane prewencyjnie wykazywały tendencję wyboru jednej hipotezy, generowały mniej powodów swojego zachowania i wybierały jedną prawdopodobną przyczynę zachowania innej osoby, wykluczając prawdopodobieństwo wystąpienia pozostałych przyczyn (Liberman, Molden, Idson, Higgins, 2001). Zaobserwowano także, że osoby o ukierunkowaniu promocyjnym generowały więcej propozycji rozwiązań nawet po doświadczeniu porażki oraz wykazywały bardziej ryzykowny wzór odpowiedzi, zaś osoby o ukierunkowaniu prewencyjnym szybciej rezygnowały i wykazywały się większą kontrolą generowanych odpowiedzi (Crowe, Higgins, 1997), co wskazuje, że ukierunkowanie prewencyjne uwrażliwia na potencjalne zagrożenie, ale może przez to prowadzić do odrzucenia bezpiecznych opcji (Bąk, 2008). Ponadto ukierunkowanie promocyjne sprzyjało częstszemu odczuwaniu emocji $\mathrm{z}$ wymiaru zadowolenia-przygnębienia, a prewencyjne odczuwaniu emocji z wymiaru spokoju-lęku (Shah, Higgins, 2001).

Lorraine Chen Idson, Nira Liberman, Christopher Camacho oraz E. Tory Higgins (1999) badali również emocje towarzyszące osiągnięciu i nieosiągnięciu celu w przypadku ukierunkowania promocyjnego i prewencyjnego. Porównywano emocje towarzyszące doświadczeniom zysku (promocyjnego sukcesu), uniknięcia porażki (prewencyjnego sukcesu), straty (prewencyjnej porażki) i ominięciu możliwości zysku (promocyjnej porażki). Z zyskiem (promocyjnym sukcesem) wiązała się raczej radość (cheerfulness) niż uczucie spokoju (quiescence), które jest charakterystyczne dla uniknięcia porażki (prewencyjnego sukcesu). Ze stratą zaś (prewencyjną porażką) wiązało się raczej uczucie poruszenia, niepokoju (agitation) niż przygnębienia (dejection), które jest charakterystyczne dla braku zysku (promocyjnej porażki). Autorzy odnieśli uzyskane rezultaty do Teorii Perspektywy, postulując, że Teoria Pespektywy i Teoria Ukierunkowań Regulacyjnych mogą się wzajemnie uzupełniać. Zdaniem autorów badań Teoria Perspektywy uwzględnia dwa 
przeciwstawne stany końcowe: zysk rozumiany jako osiągnięcie pożądanego stanu końcowego oraz stratę rozumianą jako zbliżenie się do niepożądanego stanu końcowego. Teoria Ukierunkowań Regulacyjnych koncentruje się na stanach pożądanych, wynikających z innych źródeł. W związku z tym w obu koncepcjach mamy do czynienia $\mathrm{z}$ odmiennym rozumieniem "nie-strat” (nonlosses). W Teorii Perspektywy „nie-strata”, a więc uniknięcie straty, jest ucieczką od niepożądanego stanu. W Teorii Ukierunkowań Regulacyjnych „nie-strata” jest prewencyjnym sukcesem, a więc osiągnięciem pożądanego stanu, jednak w postaci celu minimalnego, w przeciwieństwie do zysku (promocyjnego sukcesu), który jest osiągnięciem stanu pożądanego $\mathrm{w}$ postaci celu maksymalnego. Idson i in. (1999) zwrócili uwagę na potrzebę dalszych prac, wiążących przewidywania Teorii Ukierunkowań Regulacyjnych i Teorii Perspektywy. W badaniach prezentowanych $\mathrm{w}$ artykule podjęto próbę sprawdzenia, jakie znaczenie mogą mieć ukierunkowania regulacyjne decydentów dla występowania efektu sformułowania.

\section{EKSPERYMENT I}

W Eksperymencie I sprawdzano, czy wzbudzenie promocyjnego $v s$. prewencyjnego ukierunkowania regulacyjnego za pomocą manipulacji eksperymentalnej zmieni podatność decydentów na występowanie efektu sformułowania. Oczekiwano, że:

Hipoteza 1: Sytuacyjne wzbudzenie ukierunkowania promocyjnego sprzyja występowaniu efektu sformułowania w domenie straty. Osoby, u których wzbudzone zostanie ukierunkowanie promocyjne, będą ulegać efektowi sformułowania jedynie $\mathrm{w}$ domenie straty. W domenie zysku będą one wykazywać indyferencję wobec opcji pewnej i ryzykownej, ponieważ zarówno opcja pewnego, jak i ryzykownego zysku sygnalizuje obecność pozytywnego rezultatu.

Hipoteza 2: Sytuacyjne wzbudzenie ukierunkowania prewencyjnego sprzyja występowaniu efektu sformułowania w domenie zysku. Osoby, u których wzbudzone zostanie ukierunkowanie prewencyjne, będą ulegać efektowi sformułowania jedynie w domenie zysku. W domenie straty będą one wykazywać indyferencję wobec opcji wyboru, ponieważ zarówno opcja pewnej, jak i ryzykownej straty sygnalizuje obecność negatywnego rezultatu. 


\section{Metoda}

W badaniu wzięło udział 46 osób - 38 kobiet i 8 mężczyzn w wieku od 20 do 59 lat $(M=31,2 ; S D=8,55)$. Dobór uczestników miał charakter ochotniczy. Badanych losowo przydzielono do dwóch grup eksperymentalnych, w których wzbudzano ukierunkowania regulacyjne, oraz do dwóch grup, w których prezentowano scenariusz decyzyjny $\mathrm{w}$ domenie zysku $v s$. domenie straty. W badaniu uwzględniono zatem następujące zmienne:

Zmienne niezależne:

- ukierunkowanie regulacyjne (prewencyjne vs. promocyjne),

- sposób sformułowania problemu - domena (zysk vs. strata),

- rodzaj opcji (pewna vs. ryzykowna).

Zmienne zależne:

- ustosunkowania wobec opcji wyboru (odczucia, ocena atrakcyjności, skuteczności, intencja do wprowadzenia danej opcji),

- wybór jednej z opcji.

Ukierunkowanie promocyjne aktywizowano skierowaną do osób badanych prośbą, aby przez kilka minut skupiły uwagę na sobie i napisały, jak ich obecne nadzieje i pragnienia różnią się od tych, które miały, gdy dorastały. W celu aktywizacji ukierunkowania prewencyjnego uczestników proszono, aby przez kilka minut skupili uwagę na sobie i napisali, jak ich obecne obowiązki i powinności różnią się od tych, które mieli, kiedy dorastali. Po wykonaniu tych zadań osobom badanym przedstawiono scenariusz decyzyjny, w którym proszono je, aby wyobraziły sobie sytuację, w której czeka je ocena okresowa w pracy, grozi im otrzymanie negatywnej oceny na sześciu kryteriach, i znalazły oferty dwóch szkoleń, które mogą pomóc im poprawić wyniki. Następnie przedstawiano im szacunki dotyczące efektów obydwu szkoleń. W domenie zysku uczestnicy otrzymywali do wyboru szkolenie, które dawało pewność, że dostaną ocenę pozytywną na dwóch kryteriach oraz szkolenie, które dawało prawdopodobieństwo równe $1 / 3$, że dostaną ocenę pozytywną na wszystkich sześciu kryteriach oraz prawdopodobieństwo równe $2 / 3$, że nie dostaną oceny pozytywnej na żadnym kryterium. W domenie straty osoby badane dokonywały wyboru między szkoleniem dającym pewność, że dostaną ocenę negatywną na czterech kryteriach oraz szkoleniem dającym prawdopodobieństwo równe $1 / 3$, że nie dostaną oceny negatywnej na żadnym kryterium oraz prawdopodobieństwo równe $2 / 3$, że dostaną ocenę negatywną na wszystkich sześciu kryte- 
riach. Po zapoznaniu się ze scenariuszem i pierwszą opcją wyboru uczestnicy badania byli proszeni o jej ocenę na czterech skalach, po czym prezentowano im drugą opcję i proszono o jej ocenę na identycznych skalach. Zastosowano skale ciągłe o długości 100 jednostek, a uczestników proszono o ocenę odczuć, jakie wzbudza dane szkolenie (od zdecydowanie negatywnych do zdecydowanie pozytywnych), jego atrakcyjności i skuteczności (od zdecydowanie niskiej do zdecydowanie wysokiej) oraz chęci jego wybrania (od zdecydowanie nie bytbym skłonny do zdecydowanie byłbym skłonny). Po zaznaczeniu ocen obydwu opcji osoby badane były proszone o wybór jednej z nich.

\section{Wyniki}

Zgodność wewnętrzna ocen dokonywanych na czterech skalach (Odczuć, Atrakcyjności, Skuteczności i Chęci wyboru szkolenia) była wysoka i wynosiła $\alpha=0,98$ dla opcji pewnej oraz $\alpha=0,97$ dla opcji ryzykownej. W związku z tym zdecydowano, że $\mathrm{w}$ analizie uwzględnione zostaną średnie oceny każdej z opcji. W celu weryfikacji hipotez zastosowano analizę wariancji dla układów z powtarzanym pomiarem, gdzie czynnikiem wewnątrzgrupowym był rodzaj opcji (pewna $v$ s. ryzykowna), a czynnik międzygrupowy stanowiła domena (zysku vs. straty). Ze względu na fakt, że w hipotezach przewidywano wystąpienie różnic wyłącznie między wybranymi podgrupami, analizę przeprowadzono odrębnie dla grup, w których stosowano różne rodzaje manipulacji ukierunkowaniem regulacyjnym. W obydwu grupach zaobserwowano istotny efekt interakcji domeny i rodzaju opcji: $F(1,18)=12,5 ; p<0,01 ; \eta^{2}=0,4$ w grupie uczestników, u których wzbudzano ukierunkowanie promocyjne oraz $F(1,24)=8,8 ; p<0,01 ; \eta^{2}=0,3 \mathrm{w}$ grupie uczestników, u których wzbudzano ukierunkowanie prewencyjne. Testy post hoc wskazywały jednak inny wzór różnic pomiędzy ocenami poszczególnych opcji w każdej z grup. Osoby, u których wzbudzano ukierunkowanie prewencyjne, wyżej oceniały pewny zysk $(M=67,30 ; S D=31,07)$ niż ryzykowny zysk $(M=33,05 ; S D=32,73 ; p<0,001)$, natomiast oceny opcji pewnej i ryzykownej w domenie straty nie różniły się istotnie w tej grupie. Inny wzór wyników otrzymano w grupie uczestników, u których wzbudzano ukierunkowanie promocyjne. Te osoby wyżej oceniały opcję ryzykownej straty $(M=66,40 ; S D=25,14)$ niż opcję pewnej straty $(M=40,88 ; S D=21,30 ; p<0,01)$, jednak ich oceny opcji w domenie zysku nie były istotnie zróżnicowane. Średnie oceny opcji przedstawiono na rysunku 1. 


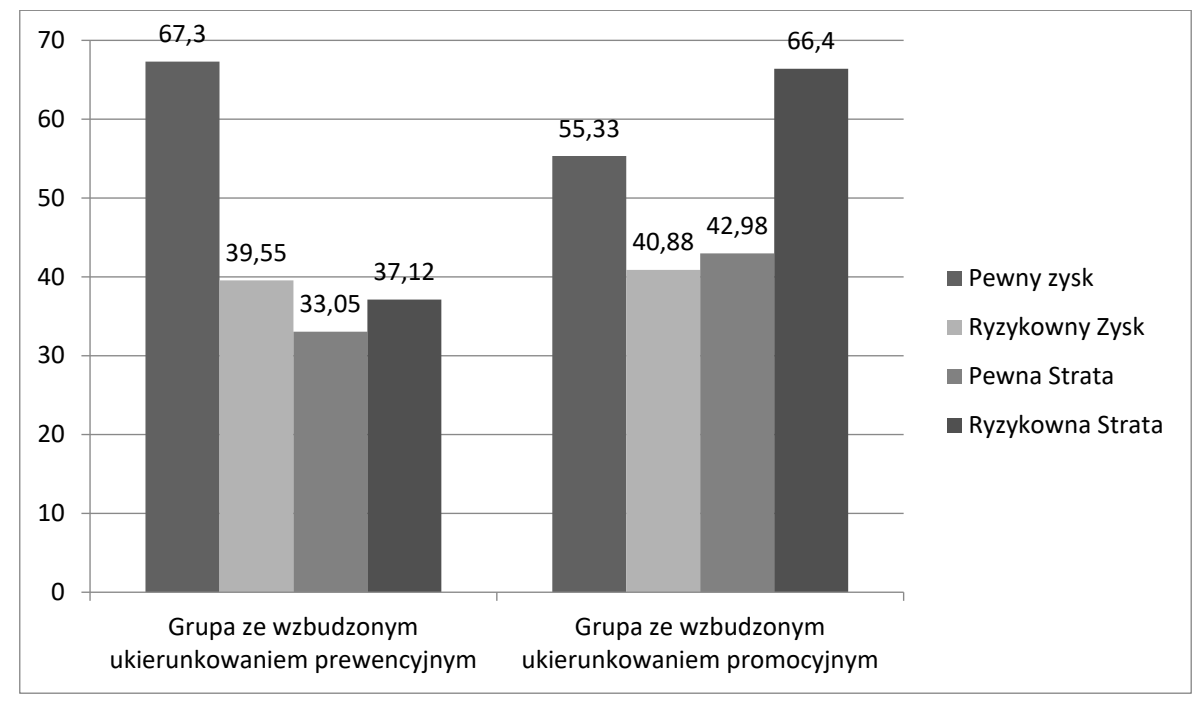

Rysunek 1. Średnie oceny opcji w dwóch grupach eksperymentalnych ze wzbudzonym ukierunkowaniem prewencyjnym i promocyjnym w Eksperymencie I.

Przeprowadzono także analizę wyborów opcji w grupach różniących się rodzajem ukierunkowania, które wzbudzano przy pomocy manipulacji. W wyborach dokonywanych w obydwu grupach wystąił istotny efekt sformułowania, zgodny z klasycznym wzorem wyników: $\chi^{2}(1)=7,20 ; p<0,01 \mathrm{w}$ grupie osób, u których wzbudzano ukierunkowanie promocyjne oraz $\chi^{2}(1)=12,76$; $p<0,001 \mathrm{w}$ grupie osób, u których wzbudzano ukierunkowanie prewencyjne.

\section{EKSPERYMENT II}

Eksperyment II miał na celu sprawdzenie, czy ukierunkowania regulacyjne, rozumiane jako względnie trwała dyspozycja decydentów, mogą modyfikować ich podatność na występowanie efektu. Mając na uwadze, że ukierunkowania regulacyjne są dwoma odrębnymi nastawieniami, z których każde może przyjmować różne natężenie niezależnie od natężenia drugiego ukierunkowania, oraz że obydwie opcje wyboru w domenie zysku sygnalizują obecność pozytywnego rezultatu, a obydwie opcje wyboru w domenie straty sygnalizują obecność negatywnego rezultatu, sformułowano dwie hipotezy: 
Hipoteza 1: Osoby $\mathrm{z}$ wysokim nasileniem ukierunkowania promocyjnego ulegają efektowi sformułowania $\mathrm{w}$ domenie straty oraz wykazują indyferencję wobec opcji wyboru w domenie zysku.

Hipoteza 2: Osoby z wysokim nasileniem ukierunkowania prewencyjnego ulegają efektowi sformułowania w domenie zysku, ale wykazują indyferencję wobec opcji wyboru w domenie straty.

Zarazem nie znaleziono przesłanek teoretycznych ani empirycznych do sformułowania hipotez dotyczących podatności na efekt sformułowania decydentów o niskim nasileniu każdego z dwóch wyróżnionych ukierunkowań.

\section{Metoda}

W badaniu wzięło udział 51 osób - 39 kobiet i 12 mężczyzn w wieku od 19 do 58 lat $(M=34,75 ; S D=8,84)$. W badaniu uwzględniono analogiczne zmienne co $\mathrm{w}$ poprzednim badaniu:

Zmienne niezależne manipulowane:

- sposób sformułowania problemu - domena (zysk vs. strata),

- rodzaj opcji (pewna $v s$. ryzykowna).

Zmienne niezależne uboczne:

- poziom ukierunkowania prewencyjnego,

- poziom ukierunkowania promocyjnego.

Zmienne zależne:

- ustosunkowania wobec opcji wyboru (odczucia, ocena atrakcyjności, skuteczności, intencja do wprowadzenia danej opcji),

- wybór jednej z opcji.

W badaniu wzięli udział ochotnicy. Uczestników losowo przydzielono do dwóch grup eksperymentalnych, w których prezentowano scenariusz decyzyjny w domenie zysku $v s$. straty. Do pomiaru nasilenia ustosunkowani regulacyjnych wykorzystano Skale samoregulacji promocyjnej i prewencyjnej - SSPP (Kolańczyk, Bąk, Roczniewska, 2013). Kwestionariusz SSPP jest narzędziem samoopisowym, które składa się z 27 stwierdzeń. Osoba badana ustosunkowuje się do ich treści poprzez zaznaczenie odpowiedzi na 5-stopniowej skali, na której 1 oznacza zdecydowanie nie zgadzam się, a 5 - zdecydowanie zgadzam się. Poszczególne pozycje przyporządkowane są do skal Promocji i Prewencji, dzięki czemu kwestionariusz pozwala ocenić nasilenie 
ukierunkowania promocyjnego oraz nasilenie ukierunkowania prewencyjnego u osoby badanej.

Na wstępie uczestnikom badania zaprezentowano scenariusz decyzyjny, który stanowił modyfikację problemu azjatyckiej choroby. Badanych poproszono, aby wyobrazili sobie, że Europejskie Centrum ds. Zapobiegania i Kontroli Chorób przygotowuje się na wybuch epidemii nowego wirusa grypy o nazwie AH3N2, która według prognoz może spowodować śmierć 600000 osób ${ }^{1}$. Następnie informowano, że zaproponowane zostały dwa alternatywne programy przeciwdziałania tej epidemii, oraz że znane są naukowe szacunki dotyczące konsekwencji obydwu programów. W domenie zysku opcję pewną prezentowano jako program, którego wprowadzenie daje pewność, że 200000 osób przeżyje, zaś opcję ryzykowną jako program, którego wprowadzenie daje prawdopodobieństwo równe $1 / 3$, że przeżyje wszystkie 600000 osób oraz prawdopodobieństwo 2/3, że nikt nie przeżyje. W domenie straty opcja pewna była opisana jako program, którego wprowadzenie daje pewność, że 400000 osób umrze, a opcja ryzykowna jako program, którego wprowadzenie daje prawdopodobieństwo równe $1 / 3$, że nie umrze nikt oraz prawdopodobieństwo 2/3, że wszystkie 600000 osób umrze. Analogicznie do pierwszego badania prezentowane opcje były oceniane na czterech skalach, a następnie uczestnicy proszeni byli o wybór jednej z nich.

Po dokonaniu wyboru uczestnicy wykonywali zadanie maskujące, które polegało na prostej kategoryzacji obiektów, a następnie wypełniali kwestionariusz SSPP.

\section{Wyniki}

Na podstawie mediany rozkładu wyników kwestionariusza SSPP dokonano podziału osób badanych na grupy: na podstawie wyniku w skali Promocji wyróżniono osoby o niższym i wyższym nasileniu ukierunkowania promocyjnego, zaś na podstawie wyniku w skali Prewencji wyróżniono osoby o niższym i wyższym nasileniu ukierunkowania prewencyjnego.

Podobnie jak w pierwszym badaniu, w analizie posłużono się średnią oceną każdej z opcji, ponieważ zgodność wewnętrzna ocen na czterech skalach była wysoka ( $\alpha=0,96$ i $\alpha=0,97$ odpowiednio dla opcji pewnej i ryzykownej). W celu weryfikacji hipotez przeprowadzono analizę wariancji w schemacie

1 Badanie zrealizowano przed pandemią wirusa SARS-CoV-2. 
z powtarzanym pomiarem, gdzie czynnikiem wewnątrzgrupowym był rodzaj opcji (pewna vs. ryzykowna), a czynnikiem międzygrupowym domena (zysk vs. strata). Ze względu na treść hipotez oraz naturę ukierunkowań regulacyjnych, które stanowią osobne wymiary, nie zaś krańce tego samego kontinuum, analizę przeprowadzono odrębnie dla grup wyróżnionych ze względu na nasilenie ukierunkowania promocyjnego i prewencyjnego.

$\mathrm{W}$ grupach różniących się nasileniem ukierunkowania promocyjnego zaobserwowano istotny efekt interakcji domeny i rodzaju opcji, świadczący o wystąpieniu efektu sformułowania problemu: $F(1,47)=16,29$; $p<0,001$; $\eta^{2}=0,26$. Analiza post hoc wykazała, że w grupie osób $o$ wyższym poziomie ukierunkowania promocyjnego oceny opcji nie różniły się istotnie w domenie zysku ani w domenie straty. Osoby o niższym poziomie ukierunkowania promocyjnego wyżej oceniały pewny zysk $(M=59,02 ; S D=19,53)$ niż ryzykowny zysk $(M=40,65 ; S D=26,21)$, nie wykazywały jednak różnicy między ocenami opcji w domenie straty. Średnie oceny opcji przedstawiono na rysunku 2.

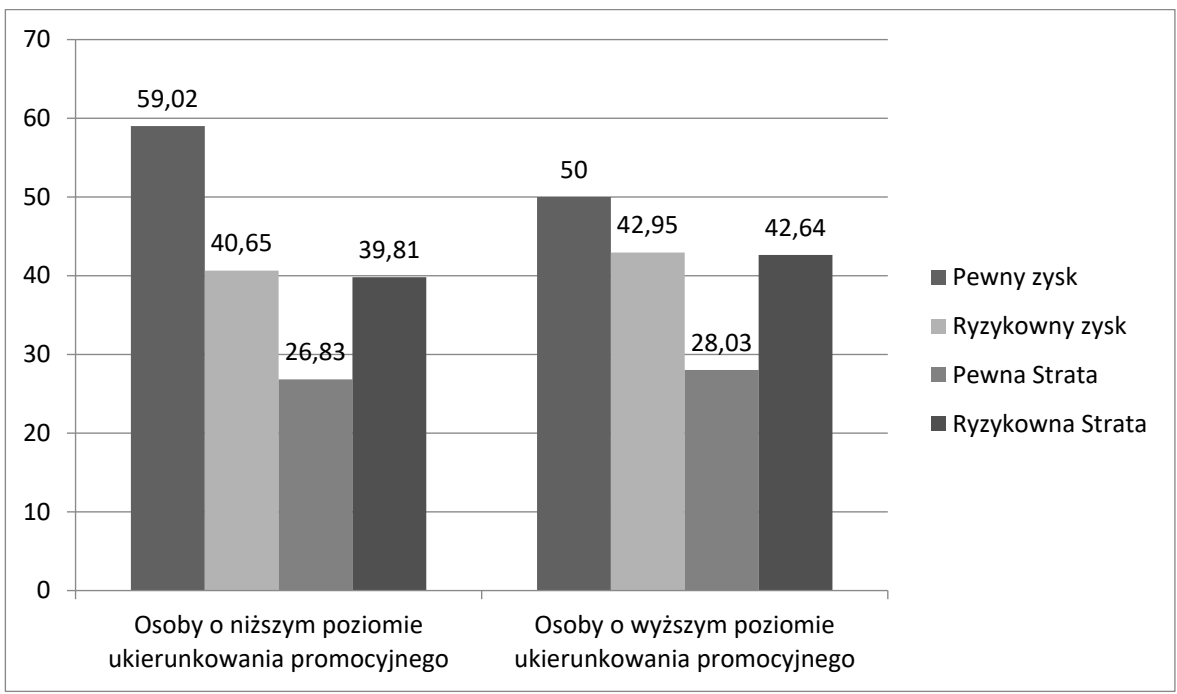

Rysunek 2. Średnie oceny opcji u osób z różnym poziomem ukierunkowania promocyjnego w Eksperymencie II.

Dla grup różniących się nasileniem ukierunkowania prewencyjnego również zaobserwowano istotny efekt interakcji domeny i rodzaju opcji: $F(1,47)=16,22$; 
$p<0,001 ; \eta^{2}=0,26$. W tym wypadku analiza post hoc pokazała, że w grupie osób o wyższym poziomie ukierunkowania prewencyjnego oceny opcji nie różniły się istotnie $\mathrm{w}$ domenie straty, ale osoby te wyżej ceniły sobie pewny zysk $(M=60,62 ; S D=23,93)$ niż zysk ryzykowny $(M=44,97 ; S D=30,88)$. Z kolei oceny opcji dokonane przez osoby o niższym poziomie ukierunkowania prewencyjnego nie różniły się istotnie ani w domenie zysku, ani w domenie straty. Średnie oceny opcji przedstawiono na rysunku 3.

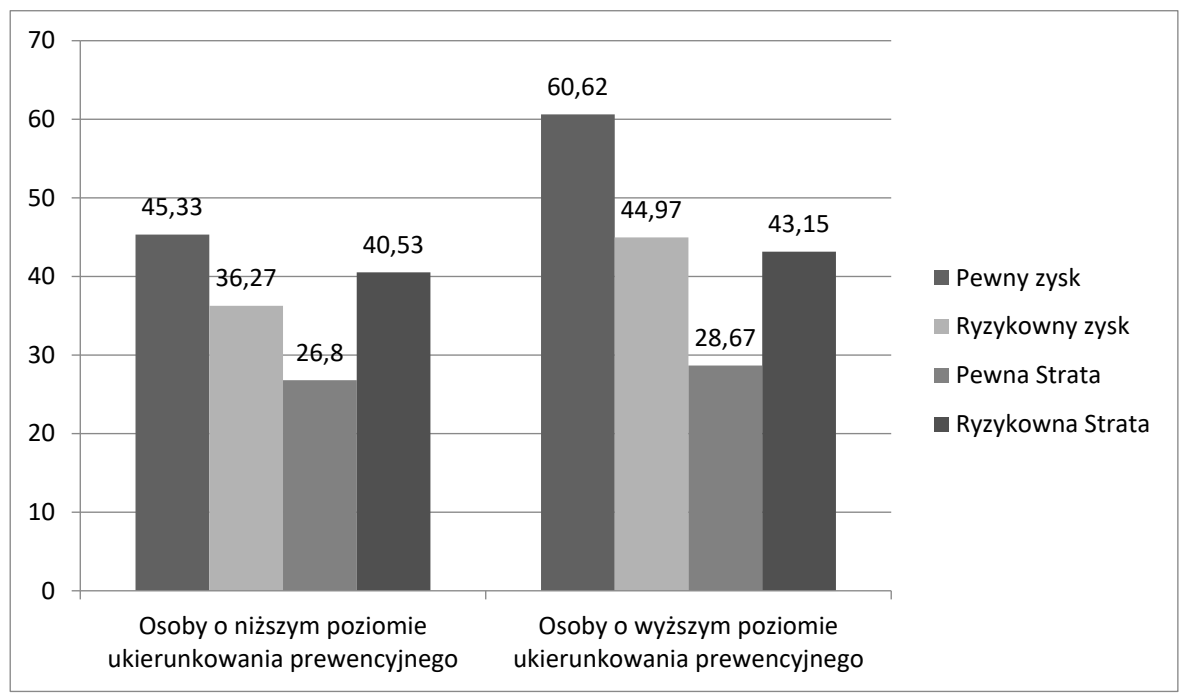

Rysunek 3. Średnie oceny opcji u osób z różnym poziomem ukierunkowania prewencyjnego w Eksperymencie II.

Dodatkowo przeprowadzono analizę wyborów opcji w grupach różniących się nasileniem ukierunkowania promocyjnego i prewencyjnego. Efekt sformułowania wystąpił zarówno u osób o ukierunkowaniu promocyjnym, jak i u osób o ukierunkowaniu prewencyjnym, odpowiednio $\chi^{2}(1)=$ 6,$62 ; p<0,01$ oraz $\chi^{2}(1)=10,80 ; p<0,001$. Zarazem w grupie o ukierunkowaniu prewencyjnym uzyskano klasyczny wzór wyborów, a w grupie o ukierunkowaniu promocyjnym efekt został zaobserwowany w domenie straty, podczas gdy w domenie zysku osoby o ukierunkowaniu promocyjnym równie chętnie wybierały opcję pewną $(n=5)$, co opcję ryzykowną $(n=6)$. W grupach osób o niższym nasileniu ukierunkowania promocyj- 
nego i prewencyjnego nie zaobserwowano istotnego efektu sformułowania w wyborach.

\section{Dyskusja}

Rezultaty, które uzyskano w przedstawionych badaniach, sugerują, że stosowanie dwóch sposobów pomiaru efektu sformułowania: wymuszonego wyboru między opcją pewną a opcją ryzykowną oraz ocen każdej z opcji niezależnie od drugiej mogą pomóc $\mathrm{w}$ zademonstrowaniu innych zależności. W pierwszym badaniu proporcja wyborów wskazywała na występowanie klasycznego efektu sformułowania, czyli preferencji opcji pewnej w domenie zysku i opcji ryzykownej w domenie straty. Zarazem analiza ocen obydwu opcji pokazała, że ich zróżnicowanie było zgodne $\mathrm{z}$ dokonanym wyborem tylko $\mathrm{w}$ domenie straty u osób $\mathrm{z}$ ukierunkowaniem promocyjnym oraz tylko $\mathrm{w}$ domenie zysku u osób z ukierunkowaniem prewencyjnym. Uwrażliwiając osoby badane na sygnały zysku lub straty przy pomocy wzbudzenia odpowiedniego ukierunkowania regulacyjnego jesteśmy więc $\mathrm{w}$ stanie osłabić występowanie efektu sformułowania, ale tylko na poziomie ocen. Kiedy wymusimy wybór jednej z opcji, ludzie nadal będą ulegać temu zniekształceniu poznawczemu. Powstaje zatem pytanie, jakie czynniki decydują o wystąpieniu efektu dla wymuszonego wyboru jednej opcji, gdy oceny tych opcji wykazują brak zróżnicowania.

W drugim badaniu, w którym nasilenie każdego z ukierunkowań regulacyjnych traktowano jako względnie stabilną właściwość decydentów, otrzymane rezultaty różniły się od tych, gdzie ukierunkowanie regulacyjne wzbudzane było eksperymentalnie. W przypadku ukierunkowania prewencyjnego rezultaty okazały się zbieżne z przewidywaniami: osoby, które uzyskały wyniki powyżej mediany w skali Prewencji, wyżej oceniały opcję pewnego zysku niż zysku ryzykownego. Za to ich oceny w domenie straty nie były zróżnicowane. Analogiczny układ wyników można zaobserwować dla osób uzyskujących wyniki poniżej mediany na skali Promocyjności, co może być związane $\mathrm{z}$ umiarkowaną ujemną korelacją obu skal $\mathrm{w}$ prezentowanym badaniu. W przypadku wyższego nasilenia ukierunkowania promocyjnego hipotezy nie znalazły jednak potwierdzenia w rezultatach badania. Zarówno w domenie zysku, jak i straty w tej grupie osób nie zaobserwowano różnic w ocenach opcji pewnej i ryzykownej. Osoby badane z tej grupy równie często dokonywały również wyboru opcji pewnego i ryzykownego zysku, co może 
wskazywać, że to opcje prezentowane jako sygnalizujące możliwy zysk były dla tych uczestników eksperymentu słabo zróżnicowane.

Rezultaty przedstawionych badań sugerują, że promocyjne i prewencyjne ukierunkowania regulacyjne mogą należeć do czynników modyfikujących podatność decydentów na wpływ sposobu sformułowania opcji wyboru w kategoriach zysków lub strat. Należy jednak zauważyć, że ukierunkowania regulacyjne traktowane jako względnie stałe właściwości jednostki nie przyniosły równie klarownego wzoru wyników, jaki uzyskano dla ukierunkowań wzbudzonych sytuacyjnie. Odpowiadać za to może fakt, że ukierunkowania te traktowane są jako odrębne konstrukty, z których każdy osiąga nasilenie niezależnie od nasilenia drugiego nastawienia. W związku z tym względnie wysokiemu nasileniu nastawienia promocyjnego może towarzyszyć relatywnie wysokie nasilenie nastawienia prewencyjnego, osoby o takiej konfiguracji nasilenia obydwu ukierunkowań mogą być uwrażliwione zarówno na sygnały możliwego zysku, jak i możliwej straty.

W dyskusji wyników warto nadmienić, że w prezentowanych badaniach zweryfikowano również efekty płci. Nie przyniosły one jednak stabilnego wzoru wyników, dlatego ze względu na objętość tekstu nie zdecydowano się na szerszą ich prezentację. W pierwszym eksperymencie płeć nie weszła w interakcję ani $\mathrm{z}$ ukierunkowaniem regulacyjnym ani domeną czy rodzajem opcji. W drugim badaniu natomiast to głównie mężczyźni generowali efekt sformułowania na poziomie ocen. U kobiet różnice pomiędzy opcjami w różnych domenach były mniejsze. Płeć nie wchodziła również $\mathrm{w}$ interakcje $\mathrm{z}$ ukierunkowaniem regulacyjnym. Warto zatem w kolejnych badaniach kontrolować tę zmienną lub zadbać o równoliczność grup.

Innym ograniczeniem opisywanych eksperymentów jest na pewno liczebność próby badawczej. Przeprowadzenie badania w próbie o większej liczebności pozwoliłoby na porównanie ocen i wyborów dokonywanych przez osoby o różnych konfiguracjach nasilenia obydwu ukierunkowań regulacyjnych. Zasadne wydaje się także zwrócenie uwagi na fakt, iż w niektórych współczesnych badaniach wnioskuje się o wystąpieniu efektu sformułowania na podstawie zróżnicowania ocen opcji pewnej i ryzykownej w domenie zysku $v s$. straty. Ten sposób pomiaru efektu może nie stanowić metody w pełni ekwiwalentnej do metody wymuszonego wyboru, który wykorzystywano w klasycznych badaniach nad efektem sformułowania. Jako ograniczenie badania można również rozpatrywać kwestie związane $\mathrm{z}$ operacjonalizacją pomiaru i manipulacji ukierunkowaniem regulacyjnym. Być może w kolejnych badaniach warto rozważyć inne cytowane w literaturze sposoby wzbudzenia 
określonego ukierunkowania lub wykorzystać inne sposoby pomiaru, choćby próbując wykluczyć korelację skal.

\section{BibLIOGRAFIA}

Aaker, J. L., Lee, A. Y. (2001). „I” seek pleasures and „we” avoid pains: The role of selfregulatory goals in information processing and persuasion. Journal of Consumer Research, 28(1), 33-49. https://doi.org/10.1086/321946

Bąk, W. (2008). Teoria ukierunkowań regulacyjnych E. Tory Higginsa. Roczniki Psychologiczne, 11(1), 7-38.

Crowe, E., Higgins, E. T. (1997). Regulatory focus and strategic inclinations: Promotion and prevention in decision-making. Organizational Behavior and Human Decision Processes, 69(2), 117-132. https://doi.org/10.1006/obhd.1996.2675

De Martino, B., Kumaran, D., Seymour, B., Dolan, R. J. (2006). Frames, biases, and rational decision-making in the human brain. Science, 313, 684-687. https://doi. org/10.1126/science.1128356

Forgas, J. P. (1995). Mood and judgment: The affect infusion model (AIM). Psychological Bulletin, 117(1), 39-66. https://doi.org/10.1037/0033-2909.117.1.39

Gonzalez, C., Dana, J., Koshino, H., Just, M. (2005). The framing effect and risky decisions: Examining cognitive functions with fMRI. Journal of Economic Psychology, 26(1), 1-20. https://doi.org/10.1016/j.joep.2004.08.004

Higgins, E. T. (1987). Self-discrepancy: A theory relating self and affect. Psychological Review, 94, 319-340. https://doi.org/10.1037/0033-295X.94.3.319

Higgins, E. T. (1997). Beyond pleasure and pain. American Psychologist, 52(12), 1280-1300. https://doi.org/10.1037/0003-066X.52.12.1280

Higgins, E. T. (1998). Promotion and prevention: Regulatory focus as a motivational principle. W: M. P. Zanna (red.), Advances in experimental social psychology, t. 30 (s. 1-46). Academic Press.

Higgins, E. T. (2002). How self-regulation creates distinct values: The case of promotion and prevention decision making. Journal of Consumer Psychology, 12(3), 177-191. https://doi.org/10.1207/S15327663JCP1203_01

Huangfu, G. (2014). Individual differences in risk-taking tendency and framing effect. Social Behavior and Personality: An International Journal, 42(2), 279-284. https:// doi.org/10.2224/sbp.2014.42.2.279

Igou, E. R., Bless, H. (2007). On undesirable consequences of thinking: Framing effects as a function of substantive processing. Journal of Behavioral Decision Making, 20, 125-142. https://doi.org/10.1002/bdm.543 
Kahneman, D. (2012). Pułapki myślenia. O myśleniu szybkim i wolnym. Poznań: Wydawnictwo Media Rodzina.

Kahneman, D., Tversky, A. (1979). Prospect theory: An analysis of decision under risk. Econometrica, 47, 263-291. https://doi.org/10.1017/CBO9780511609220.014

Kolańczyk, A., Bąk, W., Roczniewska, M. (2013). Skala samoregulacji promocyjnej i prewencyjnej (SSPP). Psychologia Społeczna, 8 2(25), 203-218.

Kornilova, T. V., Pavlova, E. M., Krasavtseva, Y. V., Razvalyaeva, A. U. (2017). Relationship between the framing effect and individual differences in medical students and psychology students. Nacional'nyj Psihologičeskij Žurnal, 4(28), 17-29. https:// doi.org/10.17759/psyedu.2019110109

Kühberger, A. (1998). The influence of framing on risky decisions: A meta-analysis. Organizational Behavior and Human Decision Processes, 75(1), 23-55. https://doi. org/10.1006/obhd.1998.2781

Kühberger, A. (2002). The rationality of risky decisions. A changing message. Theory \& Psychology, 12(4), 427-452. https://doi.org/10.1177/0959354302012004293

Kühberger, A., Gradl, P. (2013) Choice, rating, and ranking: Framing effects with different response modes. Journal of Behavioral Decision Making, 26(2), 109-117. https://doi.org/10.1002/bdm.764

Kühberger, A., Schulte-Mecklenbeck, M., Perner, J. (1999). The effects of framing, reflection, probability, and payoff on risk preference in choice tasks. Organizational Behavior and Human Decision Processes, 78(3), 204-231. https://doi.org/10.1006/obhd.1999.2830

Lauriola, M., Levin, I. P. (2001). Personality traits and risky decision-making in a controlled experimental task: An exploratory study. Personality and Individual Differences, 31(2), 215-226. https://doi.org/10.1016/S0191-8869(00)00130-6

Levine, J. M., Higgins, E. T., Choi, H.-S. (2000). Development of strategic norms in groups. Organizational Behavior and Human Decision Processes, 82(1), 88-101. https://doi.org/10.1006/obhd.2000.2889

Liberman, N., Idson, L. C., Camacho, C. J., Higgins, E. T. (1999). Promotion and prevention choices between stability and change. Journal of Personality and Social Psychology, 77(6), 1135-1145. https://doi.org/10.1037/0022-3514.77.6.1135

Liberman, N., Molden, D. C., Idson, L. C., Higgins, E. T. (2001). Promotion and prevention focus on alternative hypotheses: Implication for attributional functions. Journal of Personality and Social Psychology, 80(1), 5-18. https://doi.org/10.1037/0022-3514.80.1.5

Markman, A. B., Baldwin, G. C., Maddox, W. T. (2005). The interaction of payoff structure and regulatory focus in classification. Psychological Science, 16(11), 852-855. https://doi.org/10.1111/j.1467-9280.2005.01625.x

Maule, A. J. (1989). Positive and negative decision frames: A verbal protocol analysis of the Asian Disease problem of Tversky and Kahneman. W: H. Montgomery, 
O. Svenson (red.), Process and structure in human decision making (s. 163-180). Chichester: Wiley.

McElroy, T., Seta, J. J. (2003). Framing effects: An analytic-holistic perspective. Journal of Experimental Social Psychology, 39(6), 610-617. https:/doi.org/10.1016/ S0022-1031(03)00036-2

Miller, P. M., Fagley, N. S. (1991). The effects of framing, problem variations, and providing rationale on choice. Personality and Social Psychology Bulletin, 17(5), 517-522. https://doi.org/10.1177/0146167291175006

Miu, A. C., Crişan, L. G. (2011). Cognitive reappraisal reduces the susceptibility to the framing effect in economic decision making. Personality and Individual Differences, 51(4), 478-482. https://doi.org/10.1016/j.paid.2011.04.020

Rutkowska, D., Przybyszewski, K. (2015). Efekt sformułowania (framing effect): zaangażowanie poznawczego wysiłku a wpływ kontekstualnych informacji o zysku lub stracie na podejmowanie decyzji. Psychologia Społeczna, 3(34), 248-265.

Shah, J., Higgins, E. T. (2001). Regulatory concerns and appraisal efficiency: The general impact of promotion and prevention. Journal of Personality and Social Psychology, 80(5), 693-705. https://doi.org/10.1037/0022-3514.80.5.693

Sieck, W., Yates, J. F. (1997). Exposition effects on decision making: Choice and confidence in choice. Organizational Behavior and Human Decision Processes, 70(3), 207-219. https://doi.org/10.1006/obhd.1997.2706

Simon, A. F., Fagley, N. S., Halleran, J. G. (2004). Decision framing: Moderating effects of individual differences and cognitive processing. Journal of Behavioral Decision Making, 17(2), 77-93. https://doi.org/10.1002/bdm.463

Spiegel, S., Grant-Pillow, H., Higgins, E. T. (2004). How regulatory fit enhances motivational strength during goal pursuit. European Journal of Social Psychology, 34(1), 39-54. https://doi.org/10.1002/ejsp.180

Sokołowska, J. (2005). Psychologia decyzji ryzykownych. Ocena prawdopodobieństwa i modele wyboru w sytuacji ryzykownej. Warszawa: Wydawnictwo SWPS Academica.

Stanovich, K. E., West, R. F. (1998). Individual differences in rational thought. Journal of Experimental Psychology: General, 127(2), 161-188. https://doi.org/10.1037/0096-3445.127.2.161

Steiger, A., Kühberger, A. (2018). A meta-analytic re-appraisal of the framing effect. Zeitschrift für Psychologie, 226(1), 45-55. https://doi.org/10.1027/2151-2604/a000321

Takemura, K. (1994). Influence of elaboration on the framing of decision. The Journal of Psychology, 128(1), 33-39. https://doi.org/10.1080/00223980.1994.9712709

Tversky, A., Kahneman, D. (1981). The framing of decisions and the psychology of choice. Science, 211, 453-458. https://doi.org/10.1126/science.7455683

Tyszka, T. (2010). Decyzje. Perspektywa psychologiczna i ekonomiczna. Warszawa: Wydawnictwo Naukowe Scholar. 
OlgA KĘSKA (iD) https://orcid.org/0000-0001-6410-2493

KAMILla BARGIEL-MATUSIEWICZ iD https://orcid.org/0000-0002-9467-2267 Wydział Psychologii, Uniwersytet Warszawski

\section{Poziom aktywności fizycznej a cenione wartości i orientacja pozytywna}

\section{The level of physical activity and preferred values and positive orientation}

Sposób cytowania: Kęska, O., Bargiel-Matusiewicz, K. (2021). Poziom aktywności fizycznej a cenione wartości i orientacja pozytywna. W: M. Huflejt-Łukasik, A. Pluta (red.), Mechanizmy psychologiczne i społeczne warunkujace formułowanie ocen oraz podejmowanie działań (s. 101-119). Warszawa: Wydawnictwo Liberi Libri. https:// doi.org/10.47943/lib.9788363487553.rozdzial05 


\section{Streszczenie}

Celem niniejszych badań było uchwycenie różnic między cenionymi wartościami (Kwestionariusz portretów [PVQ-IV; Schwartz i in., 2001] w polskiej adaptacji Zaleskiego i Cieciucha [2011]) i poziomem orientacji pozytywnej (Skala orientacji pozytywnej Caprary i in. [2012] w polskiej adaptacji Łaguny, Olesia i Filipiuk [2011]) wśród osób aktywnych i nieaktywnych fizycznie. Analizie został poddany również poziom zaangażowania tych osób w kontrolę swojej masy ciała oraz ich nawyki żywieniowe (Ankieta stylu życia i nawyków żywieniowych - narzędzie opracowane przez Kęskę [2018] - materiały nieopublikowane). W celu zweryfikowania postawionych hipotez zbadano metodą ankietową osoby Polski z podziałem na płeć, wiek, wykształcenie, miejsce zamieszkania, a także poziom aktywności fizycznej. Badanie odbyło się między styczniem a marcem 2018 roku i objęło swoim zasięgiem 211 osób.

Nie wykazano różnic w zakresie orientacji pozytywnej w badanej grupie. Osoby aktywne fizycznie bardziej ceniły jednak takie wartości jak: kierowanie sobą, stymulacja, osiągnięcia i władza. Uzyskały one także wyższe wyniki w zakresie stosowanych nawyków żywieniowych i dotyczące kontroli masy ciała.

Słowa kluczowe: aktywność fizyczna, wartości, orientacja pozytywna

\section{Abstract}

The aim of the study was to capture the differences between preferred values (Portrait Values Questionnaire [PVQ; Schwartz et al., 2001] in the Polish adaptation of Zaleski and Cieciuch [2011]) and positive orientation (Positivity Scale [P-Scale] by Caprara et al. [2012] in the Polish adaptation of Łaguna, Oleś and Filipiuk [2011]) among physically active and inactive people. The level of involvement in weight control and eating habits of the respondents were also analyzed (Questionnaire on Lifestyle and Eating Habits - research tool developed by Kęska [2018], unpublished). 
In order to verify the hypotheses, Polish people were examined using the survey method, broken down by gender, age, education and place of residence as well as the level of physical activity. The survey took place between January and March 2018 and covered 211 people. There were no differences in terms of positive orientation in the study group. Physically active people, however, preferred more such values as self-direction, stimulation, achievement and power. They also obtained higher scores in terms of their eating habits and weight control.

Keywords: physical activity, preferred values, positive orientation

Aktywność fizyczna odgrywa ogromną rolę w utrzymaniu zdrowia oraz w profilaktyce i terapii wielu chorób. Stanowi także nieodzowny element zaleceń organizacji zajmujących się tematyką zdrowia. Światowa Organizacja Zdrowia (World Health Organization - WHO) w swoich rekomendacjach podaje iż dorośli w wieku 18-64 lat powinni wykonywać co najmniej 150 minut aerobowej aktywności fizycznej o umiarkowanym natężeniu lub 75 minut intensywnej aerobowej aktywności fizycznej w ciągu tygodnia lub równoważne połączenie aktywności o umiarkowanej i dużej intensywności, wykonywanych w co najmniej 10-minutowych odcinkach czasowych. W celu uzyskania dodatkowych korzyści zaleca zwiększenie aerobowej, umiarkowanej aktywności do 300 minut w tygodniu lub intensywnej do $150 \mathrm{~min}$. Z kolei działania wzmacniające mięśnie powinny być wykonywane z udziałem głównych grup mięśni w dwa lub więcej dni w tygodniu. Zalecenia wymienione powyżej dotyczą zachowania zdrowia w obszarach układu sercowo-oddechowego (choroba niedokrwienna serca, choroby sercowo-naczyniowe, udar i nadciśnienie), zdrowia metabolicznego (cukrzyca i otyłość), zdrowia kości (osteoporoza), przeciwdziałaniu nowotworom piersi i okrężnicy, a także depresji (WHO, 2010). Podobne zalecenia zostały zebrane $\mathrm{w}$ publikacji The physical activity guidelines for Americans w 2018 roku (Piercy i in., 2018). W pracy tej zwrócono również szczególną uwagę na zdrowotne korzyści regularnej aktywności fizycznej, do których należą: mniejsze ryzyko ogólnej śmiertelności oraz spowodowanej chorobami sercowo-naczyniowymi, mniejsze ryzyko chorób sercowo-naczyniowych, 
nadciśnienia tętniczego, cukrzycy typu 2., niekorzystnego profilu lipidowego, nowotworów pęcherza, piersi, jelita grubego, endometrium, przełyku, nerek, płuc i żołądka, zmniejszone ryzyko demencji (w tym choroby Alzheimera), lęku, depresji, lepsza jakość życia oraz snu, spowolniony lub zmniejszony przyrost masy ciała / utrata masy ciała, poprawione zdrowie kości, niższe ryzyko upadków i wyższa sprawność fizyczna (Piercy i in., 2018).

Istotny wpływ aktywności fizycznej na dobrostan człowieka kieruje badaczy do pytań o psychologiczne aspekty jej podejmowania. W niniejszych badaniach skupiono się w szczególności na dwóch takich aspektach, tj. cenionych wartościach oraz orientacji pozytywnej.

Zgodnie z teorią Shaloma Schwartza, wartości są specyficznymi dyspozycjami motywacyjnymi, prowadzącymi człowieka do określonych działań poprzez wpływ na jego motywację, zbudowaną na przekonaniach i uczuciach. Dyspozycje te nie są w pełni uświadamiane i kształtują się w osobniczą hierarchię w toku życia jednostki. Pomimo swojej uniwersalności i niezależności od danej sytuacji, mają względną ważność, czego skutkiem może być to, że dane zachowanie czy rozwój wydarzeń może aktywować odmienne wartości w różnym kontekście (Schwartz, 2006, 2009). Wersja teorii Schwartza, na bazie której powstało użyte w badaniach narzędzie Portrait Values Questionnaire (PVQ) w polskiej adaptacji Cieciucha i Zaleskiego (2011), obejmuje 10 wartości: bezpieczeństwo (security), władzę (power), osiągnięcia (achievement), hedonizm (hedonism), stymulację (stimulation), kierowanie sobą (self-direction), uniwersalizm (universalism), życzliwość (benevolence), tradycję (tradition) oraz przystosowanie (conformity). Struktura wartości opiera się na dwóch cechach: kontinuum i kołowości. Kontinuum oznacza, że każda wartość jest odrębną, wydzieloną jednostką, jednak te znajdujące się obok siebie są wartościami podobnymi motywacyjnie. $\mathrm{Z}$ uwagi na kołowość modelu - przeciwległe wartości są niemożliwe do realizacji w jednym działaniu, a także sprzeczne psychologicznie (Cieciuch, 2013). Badania z 2017 roku na grupie 121495 osób z różnych krajów skupiły się na relacjach między wartościami osobistymi a zadowoleniem z życia (life satisfaction - LS) i depresji (depressive affect- DEP). Zgodnie z przewidywaniami, otwartość na zmiany (openness to change), do której należą kierowanie sobą, stymulacja i hedonizm, była pozytywnie skorelowana $\mathrm{z}$ subiektywnie odczuwanym dobrostanem, natomiast zachowawczość (conservation) - negatywnie (Sortheix, Schwartz, 2017). Praca Sagiv, Roccas, Cieciucha i Schwartza (2017) miała $\mathrm{z}$ kolei za zadanie podsumować miejsce wartości w życiu człowieka i ich związek m.in. $z$ religijnością, wyborem zawodu czy relacjami $z$ innymi 
ludźmi. Dała ona także perspektywę dla zgłębiania w kolejnych badaniach innych aspektów życia opartych o wartości, które są traktowane jako podstawowy aspekt tożsamości człowieka. Poprzez wpływ na postawy i zachowania mogą służyć jako jednoczący konstrukt łączący subdyscypliny psychologii.

Druga ze zmiennych analizowanych przez autorki w kontekście aktywności fizycznej, czyli orientacja pozytywna, jest komponentem, który ma za zadanie opisać tendencję do zwracania uwagi na wszelkie pozytywne aspekty własnego życia, doświadczeń, a także samego siebie. Konstrukt ten składa się $\mathrm{z}$ takich aspektów, jak: samoocena, zadowolenie z życia oraz optymizm, co w nurcie psychologii pozytywnej określa go jako czynnik adaptacyjny dla funkcjonowania jednostki (Caprara, 2009; Petrović, 2010; Seligman, Csikszentmihalyi, 2000; Trzebińska, 2008). Orientacja pozytywna jest również czasami określana odwrotnością triady depresji Becka (Beck, 1967), o czym może świadczyć chociażby fakt, że opiera się ona na założeniu postrzegania siebie i swojego życia jako pozytywnych, pomimo napotykanych trudności, przeciwności losu, strat materialnych i emocjonalnych, przykrości dnia codziennego czy też - wizji śmierci (Łukasik, Witek, 2018). Opisywane tak nastawienie do świata i innych ludzi pomaga silniej zaangażować się w realizację celów, wykorzystywanie swoich mocnych stron, radzenie sobie z sytuacjami stresowymi, a także wiąże się ze zwiększoną satysfakcją z życia (Caprara i in., 2012; Caprara i in., 2009; Petrović, 2010). Tak rozumiana orientacja pozytywna kieruje nas ku pytaniom o związki pomiędzy poziomem orientacji pozytywnej a podejmowaniem aktywności fizycznej. Pośrednio odpowiedzi na to pytanie można szukać w pracy Kupcewicz, Szypulskiej i Doboszyńskiej (2019). Autorki badały w zakresie orientacji pozytywnej i zachowań prozdrowotnych pacjentów ortopedycznych poddanych rehabilitacji ortopedycznej związanej z urazami ruchowymi, narządów, chorobami zwyrodnieniowymi lub nabytymi zmianami kostno-stawowymi i mięśniowymi oraz pacjentów z udarem z ogólnymi zaburzeniami ruchowymi. Zbadanymi kategoriami zdrowego zachowania były: właściwe nawyki żywieniowe (rodzaj spożywanej żywności), zachowania zapobiegawcze (przestrzeganie zaleceń zdrowotnych), praktyki zdrowotne (m.in. codzienne nawyki związane ze snem i rekreacją oraz aktywnością fizyczną), pozytywne nastawienie psychiczne (związane z unikaniem intensywnych emocji, stresów czy napięć). Wyniki pokazały, że pozytywna orientacja odgrywała istotną rolę w przewidywaniu nasilenia zdrowych zachowań związanych z pozytywnym nastawieniem psychicznym, a tym samym - wypracowaniem bardziej pozytywnego podejścia do choroby. 
Nie ujawniła jednak siły predykcyjnej zachowań prewencyjnych czy nasilenia zdrowych praktyk (w przeciwieństwie do wieku badanych; Kupcewicz i in., 2019). Badania Łukasik i Witek (2018) wykazały z kolei dodatnią korelację między orientacją pozytywną a nadzieją na sukces. Autorki zaobserwowały, że pozytywna orientacja może być czynnikiem chroniącym przede wszystkim przed chorobami psychicznymi (Łukasik, Witek, 2018). Wcześniejsze badania pokazują również, że pozytywne postawy mają długotrwały wpływ na rokowania w starszym wieku (Pitkala, Laakkonen, Strandberg, Tilvis, 2004). W odniesieniu do cenionych wartości orientacja pozytywna koreluje dodatnio z wartościami takimi jak osiągnięcia i stymulacja $\mathrm{z}$ koncepcji Schwartza, a ponadto $\mathrm{z}$ oceną stanu zdrowia oraz przekonaniem o własnej skuteczności (Cieciuch, Zaleski, 2011). Tak opisany konstrukt teoretyczny doczekał się narzędzia badawczego Positivity Scale (P Scale) przygotowanego przez Caprarę i in. (2012; polska adaptacja: Łaguna, Oleś, Filipiuk, 2011). Narzędzie to zostało wykorzystane do przeprowadzania niniejszych badań.

Prezentowane tu badania miały za zadanie uchwycić różnice między cenionymi wartościami i poziomem orientacji pozytywnej wśród osób aktywnych i nieaktywnych fizycznie. Analizie został poddany również poziom zaangażowania tych osób w kontrolę swojej masy ciała oraz ich nawyki żywieniowe.

\section{MetodA}

\section{Narzędzia badawcze}

Do badań wykorzystano przedstawione poniżej narzędzia.

- Ankieta stylu życia i nawyków żywieniowych (Kęska, 2018, materiały nieopublikowane).

Ankieta dotyczy obszarów z zakresu danych demograficznych (wiek, wzrost, masa ciała, wykształcenie, miejsce zamieszkania, stan cywilny, występowanie chorób przewlekłych itp.), stylu życia (aktywność fizyczna, sen, stosowanie leków i suplementów diety itp.), a także kontroli masy ciała (np. „Czy ważysz się regularnie?”) i nawyków żywieniowych (np. „Czy spożywasz codziennie warzywa i owoce?”). Do opracowania pytań o nawyki żywieniowe zostały wykorzystane zalecenia żywieniowe Instytutu Żywności i Żywienia oraz literatura specjalistyczna (Ciborowska, Rudnicka, 2007; Grzymisławski, Gawęcki, 2012; Jarosz, 2017; Kłosiewicz-Latoszek, 2009). 
- Kwestionariusz portretów (PVQ-IV) Schwartza i in. (2001) w polskiej adaptacji Zaleskiego i Cieciucha (2011).

Kwestionariusz portretów składa się z 43 itemów. Każda pozycja zawiera po dwa zdania opisujące jakiś cel lub aspirację jednostki wraz z dodatkowym wyjaśnieniem. Badana osoba ma za zadanie oznaczyć na 6-stopniowej skali (w której 1 oznacza bardzo podobny do mnie, 2 - podobny do mnie, 3 - prawie podobny do mnie, 4 - troche podobny do mnie, 5 - niepodobny do mnie, a 6 zupetnie niepodobny do mnie), jak bardzo jest podobna do opisanej osoby.

Kwestionariusz został przygotowany w oparciu o koncepcję wartości Shaloma Schwartza, w której wyróżnia się następujące wartości o rzetelności alfa Cronbacha: bezpieczeństwo - 0,59, władza - 0,70, osiągnięcia - 0,72, hedonizm - 0,8, stymulacja - 0,63, kierowanie sobą - 0,65 , uniwersalizm 0,75 , życzliwość $-0,64$, tradycja - 0,61 oraz przystosowanie - 0,58 (Cieciuch, Zaleski, 2011; Schwartz, 2006, 2009).

- Skala orientacji pozytywnej Caprary i in. (2012) w polskiej adaptacji Łaguny, Olesia i Filipiuk (2011).

Kwestionariusz ten składa się z 8 twierdzeń, do których osoba badana ma za zadanie ustosunkować się na 5-stopniowej skali, gdzie: 1 oznacza $z$ decydowanie się nie zgadzam, 2 - nie zgadzam się, 3 - ani się zgadzam, ani się nie zgadzam, 4 - zgadzam się, a 5 - zdecydowanie zgadzam się. Wynikiem jest suma punktów z wszystkich pozycji (od 8 do 40 punktów), a im wyższy wynik, tym wyższy poziom orientacji pozytywnej osoby badanej. Metoda w polskiej wersji językowej posiada jednoczynnikową strukturę i wykazuje spójność wewnętrzną $a=0,77-0,84$, stałość $(\mathrm{rtt}=0,84)$, a także potwierdzoną trafność zbieżną.

Narzędzie to jest oparte na koncepcji orientacji pozytywnej, łączącej trzy komponenty: samoocenę, optymizm i satysfakcję z życia (Caprara i in., 2012; Łaguna, Oleś, Filipiuk, 2011).

\section{Osoby badane}

$\mathrm{W}$ anonimowym badaniu ankietowym, prowadzonym drogą internetową od stycznia do marca 2018 roku, wzięło udział 211 osób pochodzenia polskiego, w tym 182 kobiety i 29 mężczyzn w wieku od 19 do 65 lat $(M=33 ; S D=9,5)$. Respondenci zostali poinformowani o celu badań i sposobie wypełniania ankiet. Wyniki badań zostały opracowane statystycznie przy pomocy programu IBM SPSS Statistics, a następnie przedstawione w formie tabel i wykresów. 


\section{WYNIKI}

Wśród zbadanych 211 osób 94 były aktywne fizycznie (aktywność co najmniej 2-3 razy w tygodniu), a 117 nie (brak aktywności lub do kilku razy w miesiącu). Wyodrębnione grupy nie różniły się między sobą pod względem rozkładu wiekowego, płci, stanu cywilnego, wykształcenia i miejsca zamieszkania. Nie odnaleziono także różnic w zakresie BMI badanych, średniej długości trwania snu oraz częstości występowania chorób przewlekłych.

Osoby nieaktywne odznaczały się częstszym stosowaniem leków, natomiast osoby aktywne - częstszym stosowaniem suplementów diety. Różnice te były istotne statystycznie.

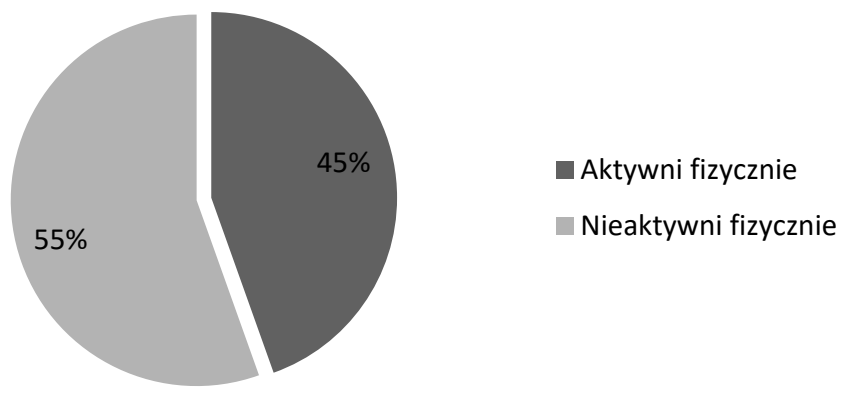

Rysunek 1. Graficzne przedstawienie podziału badanych na osoby aktywne i nieaktywne fizycznie ( $N=211)$.

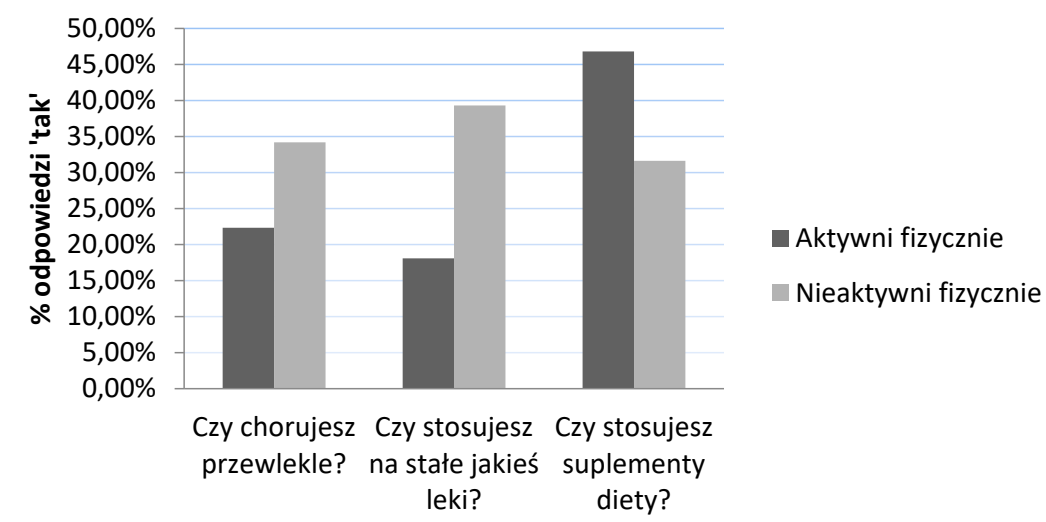

Rysunek 2. Graficzne przedstawienie różnic w zakresie stosowania leków i suplementów diety wśród osób aktywnych i nieaktywnych fizycznie w badanej grupie $(N=211)$. 
Tabela 1

Różnice w stosowaniu leków i suplementów diety wśród osób aktywnych i nieaktywnych fizycznie ( $\mathrm{N}=211)$

\begin{tabular}{lccc}
\hline & Czy chorujesz przewlekle? & $\begin{array}{c}\text { Czy stosujesz na stałe jakieś } \\
\text { leki? }\end{array}$ & $\begin{array}{c}\text { Czy stosujesz suplementy } \\
\text { diety? }\end{array}$ \\
\hline $\begin{array}{l}\text { U Manna- } \\
\text {-Whitneya }\end{array}$ & 4847,500 & 4331,500 & 4664,000 \\
$Z$ & $-1,88$ & $-3,34$ & $-2,25$ \\
$p$ & 0,060 & 0,001 & 0,025 \\
\hline
\end{tabular}

Adnotacja. Zmienna grupująca: „Jak często uprawiasz sport?”; Z - wartość statystyki w teście U Manna-Whitneya (istotność dwustronna).

Ponadto osoby aktywne od nieaktywnych różniły się istotnie statystycznie w zakresie nawyków żywieniowych oraz kontroli masy ciała. Osoby aktywne fizycznie uzyskały wyższe wyniki w obu wymiarach.

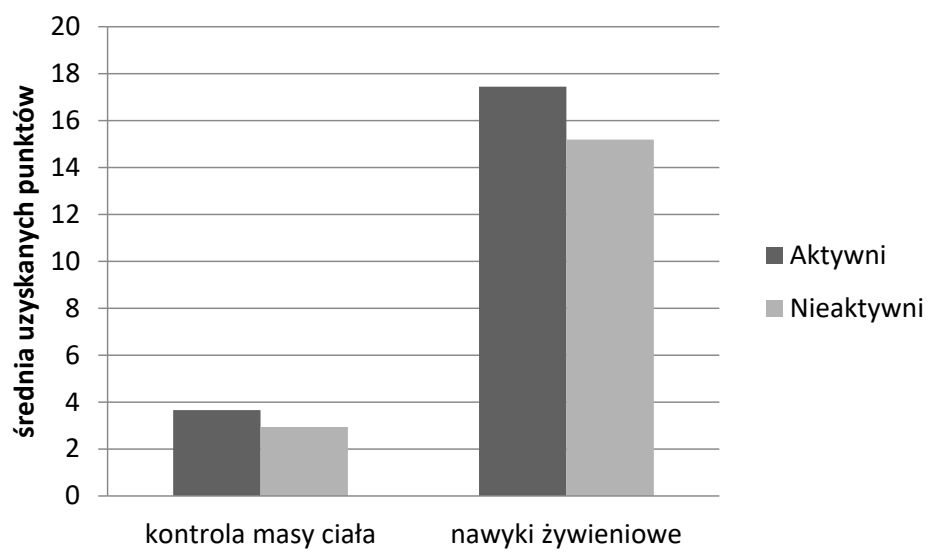

Rysunek 3. Graficzne przedstawienie różnic w kontroli masy ciała i nawyków żywieniowych wśród osób aktywnych i nieaktywnych fizycznie $(N=211)$. 
Tabela 2

Kontrola masy ciała i nawyki żywieniowe wśród osób aktywnych i nieaktywnych fizycznie ( $\mathrm{N}=211)$

\begin{tabular}{lcc}
\hline & SUMA kontroli masy ciała & SUMA nawyki żywieniowe \\
\hline U Manna-Whitneya & 4271,000 & 3956,000 \\
$Z$ & $-2,83$ & $-3,51$ \\
$p$ & 0,005 & 0,000 \\
\hline
\end{tabular}

Adnotacja. Zmienna grupująca: „Jak często uprawiasz sport?”; Z - wartość statystyki w teście U Manna-Whitneya (istotność dwustronna).

W skali Kontroli masy ciała największe różnice w badanych grupach dotyczyły pytań: „Czy liczyłeś kiedykolwiek swoje zapotrzebowanie kaloryczne?” oraz „Czy korzystasz z miar kuchennych/wagi kuchennej podczas przygotowywania posiłków?”.

W skali Nawyków żywieniowych różnice zauważono w odpowiedziach na pytania: „Ile posiłków głównych dziennie spożywasz?”, „Do ilu godzin od obudzenia się jesz zazwyczaj śniadanie?”, „Czy spożywasz codziennie warzywa i owoce?”, „W ilu posiłkach dziennie spożywasz warzywa?”, „W ilu posiłkach dziennie spożywasz owoce?”, „Jaki rodzaj pieczywa spożywasz najczęściej?”, "Czy unikasz spożywania cukru i słodyczy?", "Jak często spożywasz cukier i/lub słodycze?”, „Czy unikasz produktów wysokoprzetworzonych?” oraz „Ile wody dziennie wypijasz?”.

Z perspektywy badanych zmiennych psychologicznych osób aktywnych i nieaktywnych fizycznie nie różnicował poziom orientacji pozytywnej. Zauważono natomiast różnice $\mathrm{w}$ zakresie cenionych wartości wśród badanych grup. Poniższe wyniki ukazały, że osoby aktywne fizycznie bardziej ceniły wartości takie jak: kierowanie sobą, stymulacja, osiągnięcia i władza. 
Tabela 3

Różnice w poziomie cenionych wartości wśród osób aktywnych i nieaktywnych fizycznie ( $\mathrm{N}=211)$

\begin{tabular}{|c|c|c|c|c|c|c|c|c|c|c|}
\hline & 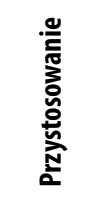 & 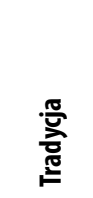 & 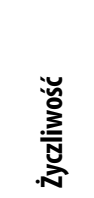 & 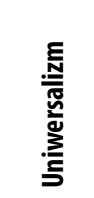 & 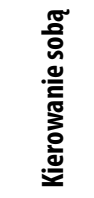 & 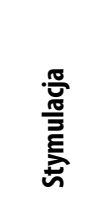 & 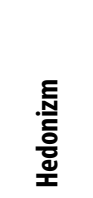 & 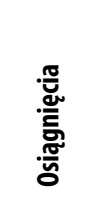 & $\begin{array}{l}\text { N } \\
\frac{\mathbb{N}}{\mathbf{T}} \\
\overline{3}\end{array}$ & 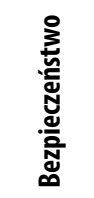 \\
\hline $\begin{array}{l}\text { U Manna- } \\
\text {-Whitneya }\end{array}$ & 5252,50 & 4957,00 & 5360,50 & 4876,50 & 4621,50 & 3667,00 & 4644,50 & 4475,50 & 4620,00 & 5261,50 \\
\hline Z & $-0,56$ & $-1,24$ & $-0,32$ & $-1,42$ & $-2,00$ & $-4,18$ & $-1,95$ & $-2,33$ & $-2,01$ & $-0,54$ \\
\hline$p$ & 0,574 & 0,217 & 0,752 & 0,157 & 0,045 & 0,000 & 0,052 & 0,020 & 0,045 & 0,589 \\
\hline
\end{tabular}

Adnotacja. Zmienna grupująca: „Jak często uprawiasz sport?”; Z - wartość statystyki w teście U Manna-Whitneya (istotność dwustronna).

\section{DYskusJa}

Jak ukazuje literatura przedmiotu, poziom aktywności fizycznej koreluje ujemnie $\mathrm{z}$ występowaniem chorób. Z jednej strony, aktywność fizyczna niewątpliwie pomaga $\mathrm{w}$ zapobieganiu chorobie, $\mathrm{z}$ drugiej $\mathrm{z}$ kolei, choroba może stać się barierą dla podejmowania aktywności fizycznej. W badanej grupie zależność między chorobami przewlekłymi a aktywnością fizyczną nie była tak silna, czego powodem może być fakt młodego wieku dużej części badanych, u których, pomimo realnego wpływu aktywności na ten parametr, choroba mogła się jeszcze nie ujawnić. Dane zebrane przez WHO, opublikowane w The Lancet Global Health, ukazują, że więcej niż 1/4 populacji światowej nie dostarcza organizmowi takiej dawki ruchu, która pozwala na uniknięcie podstawowych chorób cywilizacyjnych. Należy tu dodać, że kobiety uprawiają mniej sportu niż mężczyźni (Guthold, Stevens, Riley, Bull, 2018). W zbadanej grupie ponad połowa osób odznaczała się zbyt niskim, w stosunku do zaleceń, poziomem aktywności fizycznej. Zaobserwowano również, że osoby nieaktywne odznaczały się częstszym stosowaniem leków, natomiast osoby aktywne - częstszym stosowaniem suplementów diety. Stosowanie leków może wiązać się oczywiście z zaistniałymi chorobami przewlekłymi, a stosowanie suplementów - z większą świadomością zdrowotną osób aktywnych. Część ze stosowanych suplementów diety stanowiły także suplementy wspomagające aktywność fizyczną, co potęguje skalę wyniku. 
Co ciekawe jednak, osoby nieaktywne fizyczne od aktywnych nie różniły się poziomem BMI ani długością czasu snu. Czynniki te mogą, niezależnie od aktywności fizycznej, wpływać na wystąpienie chorób przewlekłych, takich jak choroby sercowo-naczyniowe czy nowotwory, a także ogólną śmiertelność, a czynniki takie jak cukrzyca, nadciśnienie, cholesterol całkowity oraz starzenie się są modyfikatorami tego efektu (Barroso i in., 2018). Wpływ BMI na wzrost ciśnienia skurczowego krwi pokazywały także badania Gajalakshmi (Gajalakshmi i in., 2018) oraz Leal Neto (Leal Neto, Barbosa, Meneghini, 2016). Inne doniesienia pokazują, że podwyższone BMI jest niezależnym czynnikiem ryzyka marskości wątroby w trzech różnych etiologiach przewlekłego zapalenia wątroby (Yen i in., 2018). Także WHO wskazuje na cztery główne konsekwencje podwyższonego BMI: choroby sercowo-naczyniowe (głównie choroby serca i udar), cukrzyca, zaburzenia mięśniowo-szkieletowe (musculoskeletal disorders - MSD), szczególnie choroba zwyrodnieniowa stawów, oraz niektóre nowotwory (w tym endometrium, piersi, jajników, prostaty, wątroby, pęcherzyka żółciowego, nerek i jelita grubego; WHO, 2015). Kohortowe badania przeprowadzone w latach 2002-2010 w Korei Południowej pokazały z kolei paradoks umiarkowanej otyłości $\left(25-29,9 \mathrm{~kg} / \mathrm{m}^{2}\right)$ u osób starszych i przewlekle chorych, która była silniej powiązana z niższym ryzykiem umieralności niż normalna masa ciała, nadwaga lub niedowaga w populacji ogólnej (Kim i in., 2015). Niemniej metaanaliza wykonana na 239 badaniach z 32 krajów przez The Global BMI Mortality Collaboration w 2016 roku ukazała, że związki nadwagi oraz otyłości z wyższą śmiertelnością z jakiejkolwiek przyczyny były zasadniczo spójne na czterech kontynentach: Azji, Europie, Ameryce Północnej oraz Australii. Badania te podważyły wcześniejsze spekulacje, jakoby podwyższona ilość tkanki tłuszczowej u pozornie zdrowych osób z nadwagą i umiarkowaną otyłością miała ochronne właściwości metaboliczne (The Global BMI Mortality Collaboration, 2016).

Również długość snu ma znaczenie w prewencji wielu chorób przewlekłych. Metanaliza Wanga i in. (2015) wykazała, że zarówno zbyt długi, jak i zbyt krótki czas snu mogą być czynnikami ryzyka wysokiego ciśnienia krwi; zależności te są silniejsze u kobiet niż u mężczyzn. Niewłaściwa długość snu może być także predyktorem lub markerem wyników sercowo-naczyniowych (Capuccio, Cooper, D’Elia, Strazzullo, Miller, 2011). Z kolei Von Ruesten (Von Ruesten, Weikert, Fietze, Boeing, 2012) zanotował w swych badaniach, że czas snu krótszy niż 6 godzin jest ryzykownym zachowaniem w rozwoju chorób przewlekłych, w szczególności udaru mózgu i nowotworów. Liczne badania konsekwentnie wykazały znaczące powiązania między ograniczeniem czasu 
snu a zmniejszeniem spoczynkowego i poposiłkowego wydatku energetycznego (odpowiednio 5\% i 20\%), zwiększony apetyt i insulinooporność w populacji ogólnej (Ding, Lim, Xu, Shan Kong, 2018). Mimo tych doniesień już sama aktywność fizyczna, nieprzynosząca zmian w masie ciała czy czasie snu, ma niebagatelne znaczenie w ich prewencji i leczeniu. Aktywność fizyczna wiąże się z niższym ryzykiem chorób przewlekłych, w szczególności: problemów z sercem, nadciśnienia, problemów z oddychaniem, alergii, cukrzycy typu 2 i otyłości. Co więcej, nawet niewielkie ilości cotygodniowej aktywności fizycznej wydają się zmniejszać ryzyko chorób przewlekłych (Marques, Santos, Martins, Gaspar de Matos, Valeiro, 2018; Piercy i in., 2018). Podobne wnioski można zauważyć w pracy Sullivana, który wyróżnia dwa główne czynniki ryzyka związane z cukrzycą typu 2: otyłość i brak aktywności fizycznej. Dowody wskazują, że częstość występowania cukrzycy jest większa u osób otyłych, z nadwagą i osób nieaktywnych fizycznie, a brak aktywności fizycznej jest niezależnie związany ze zwiększonym ryzykiem każdej z tych chorób (Sullivan, Morrato, Ghushchyan, Wyatt, Hill, 2005). González Fuentes i Márquez (2017) zwracają uwagę na konieczność rozgraniczenia pojęć aktywności fizycznej i jej braku od siedzącego trybu życia. Według nich sama aktywność fizyczna, na zalecanym przez WHO poziomie, nie wystarczy, aby zmniejszyć prawdopodobieństwo wystąpienia choroby przewlekłej. Konieczne jest także unikanie spędzania zbyt długiego czasu w pozycji siedzącej. Jest to ważna wskazówka dotycząca projektowania kolejnych badań dotyczących związków między aktywnością fizyczną a stanem zdrowia.

Niniejsze badania ukazały także kolejny ważny aspekt dotyczący aktywności fizycznej - która nie tylko pomaga w zmniejszaniu masy ciała i ma wpływ na zmniejszenie prawdopodobieństwa występowania chorób przewlekłych, ale także wiąże się z prozdrowotnymi działaniami jednostki. Osoby aktywne od nieaktywnych różniły się istotnie statystycznie w zakresie nawyków żywieniowych oraz kontroli masy ciała. Wśród nawyków żywieniowych można zauważyć szczególne różnice między aktywnymi i nieaktywnymi osobami w zakresie liczby i godzin spożywanych posiłków, spożywania warzyw i owoców, wyboru rodzaju pieczywa, spożywania cukru i słodyczy, spożywania produktów wysokoprzetworzonych, a także ilości wypijanej wody. Osoby aktywne częściej liczyły swoje zapotrzebowanie kaloryczne i korzystały z miar kuchennych i wagi podczas przygotowywania posiłków. Może to świadczyć o większej świadomości zachowań prozdrowotnych wśród osób aktywnych fizycznie. Taką korelację zauważono już w badaniach Blaira, Jacobsa i Powella (1985). Konieczność skupienia się na innych prozdrowotnych zachowaniach, 
poza samą aktywnością fizyczną, zauważyli także Warburton i Bredin (2017), podważając jednocześnie aktualne progi aktywności fizycznej zalecane w celu poprawy zdrowia. Badacze ci sugerują, że wystarczy zwiększenie aktywności fizycznej w połączeniu z innymi zachowaniami prozdrowotnymi, niekoniecznie musi ono osiągać rekomendowany poziom.

Wśród zbadanych zmiennych psychologicznych nie wykazano zależności pomiędzy aktywnością fizyczną a poziomem orientacji pozytywnej, co niejako może kłócić się z samym opisem tej zmiennej, jakoby osoby o tej cesze bardziej angażowały się w dążenia życiowe i wysoko oceniały szansę realizacji celów (Caprara, 2009; Caprara i in., 2012). Z drugiej jednak strony, orientacja pozytywna, pomimo że w pewnym stopniu jest uwarunkowana genetycznie (Caprara i in., 2009), to należy pamiętać, że ten fakt nie determinuje pojawienia się danej cechy, a stanowi jedynie potencjał, który może (ale nie musi) się ujawnić w życiu jednostki w oparciu o okoliczności i historię życiową. Nie powinno się zatem, bez wprowadzenia interakcji z odpowiednimi zmiennymi i analizy dodatkowych aspektów, wykazywać różnic pomiędzy grupami. W wynikach badań stwierdzono natomiast różnice $\mathrm{w}$ zakresie cenionych wartości wśród badanych grup. Wykazano, że osoby aktywne fizycznie bardziej ceniły takie wartości jak: kierowanie sobą, stymulacja, osiągnięcia i władza. Wartości te należą do dwóch wymiarów wartości opisywanych przez Schwartza tj. otwartości na zmiany (openess to change), do której zaliczamy stymulację i kierowanie sobą, oraz umacniania Ja (self-enhancement) - do którego zaliczamy osiągnięcia i władzę. Wymiary te opisują wartości niezależności myśli i działań oraz gotowość na zmiany (otwartość na zmiany) oraz wartości odnoszące się do zaspokajania własnych potrzeb, pragnień i interesów (umacnianie Ja; Cieciuch, 2013; Cieciuch, Zaleski, 2011). Podobne wyniki zaobserwowano wcześniej wśród chorych na cukrzycę typu 2, gdzie osoby wybierające w terapii cukrzycowej aktywność fizyczną częściej od osób nieaktywnych ceniły wartość stymulacji (Kęska, Bargiel-Matusiewicz, 2018). Osoby te ceniły także silniej wartość hedonizmu - będącego wartością znajdującą się na pograniczu wymiarów otwartości na zmianę i umacniania Ja oraz wartość bezpieczeństwa. Taki wynik nieco odbiega od tych $\mathrm{z}$ aktualnych badań, jednak może wskazywać na zmianę priorytetów wśród osób chorych w kierunku chęci odnalezienia źródła przyjemności w cierpieniu, a także dbania o swoje zdrowie w celu jego poprawy i zabezpieczenia bytu rodziny. Pomimo tych różnic wciąż znajdujemy się po jednej stronie koła modelu wartości Schwartza, dotyczącego koncentracji na sobie (Schwartz, 2006; Schwartz i in., 2012). 


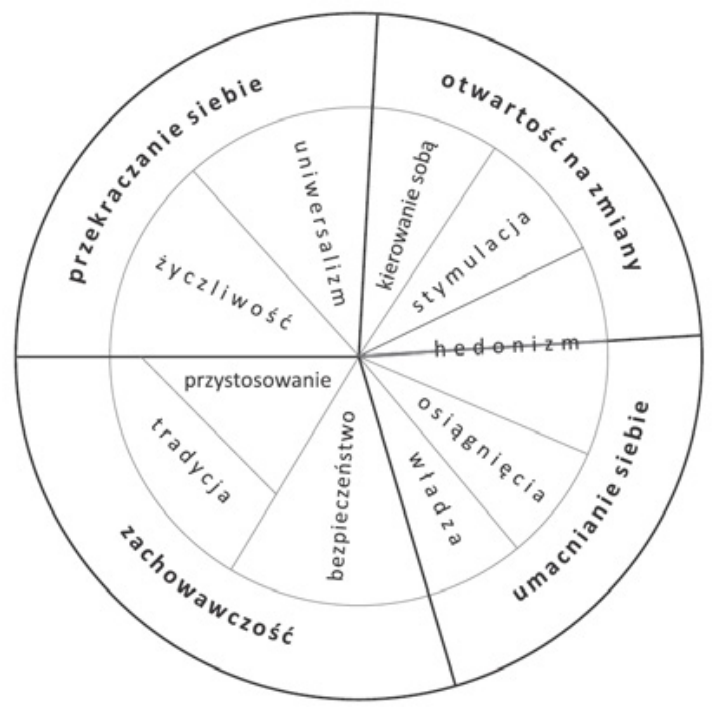

Rysunek 4. Koło wartości Schwartza w modelu klasycznym. Źródło: Cieciuch (2013) na podstawie Schwartz (2006).

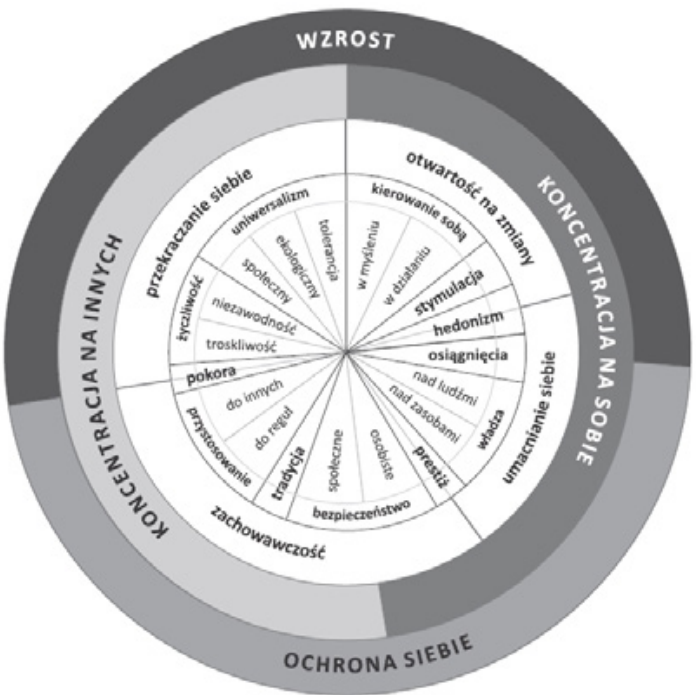

Rysunek 5. Koło wartości Schwartza w modelu zmodyfikowanym.

Źródło: Cieciuch (2013) na podstawie Schwartz i in. (2012). 
Koncentracja na sobie $w$ takim ujęciu jest zjawiskiem pozytywnym $z$ uwagi na jej powiązanie z zachowaniami prozdrowotnymi. Kierunkiem działań w edukacji powinno być zatem wykształcanie postaw opartych na wspomnianych wyżej wartościach, aby od samego początku budować motywację wewnętrzną do podejmowania aktywności fizycznej, dbania o nawyki żywieniowe oraz kontroli masy ciała. Jest to tym bardziej istotne, jako że sam fakt wystąpienia otyłości nie wiąże się znacząco z dyspozycjami motywacyjnymi, co pokazują wyniki badań Tekeş i współpracowników (Tekeş, Üzümcüoğlu, Hoe, Özkan, 2018). Wobec powyższego, w pośrednich działaniach na poziomie motywacji do ćwiczeń oraz nawyków prozdrowotnych możemy upatrywać sukcesu prewencyjnego lub leczniczego wielu chorób oraz otyłości.

\section{BibLIOGRAFIA}

Barroso, M., Goday, A., Ramos, R., Marín-Ibañez, A., Guembe, M. J., Rigo, F., ..., Marrugat, J. (2018). Interaction between cardiovascular risk factors and body mass index and 10-year incidence of cardiovascular disease, cancer death, and overall mortality. Preventive Medicine, 107, 81-89. https://doi.org/10.1016/j.ypmed.2017.11.013

Beck, A. T. (1967). Depression: Clinical, experimental and theoretical aspects. Nowy Jork: Hoeber.

Blair, S. N., Jacobs, D. R., Powell, K. E. (1985). Relationships between exercise or physical activity and other health behaviors. Public Health Reports, 100(2), 172-180.

Cappuccio, F. P., Cooper, D., D’Elia, L., Strazzullo, P., Miller, M. A. (2011). Sleep duration predicts cardiovascular outcomes: A systematic review and meta-analysis of prospective studies. European Heart Journal, 32(12), 1484-1492. https://doi. org/10.1093/eurheartj/ehr007

Caprara, G. V. (2009). Positive orientation: Turning potentials into optimal functioning. The Bulletin of the European Health Psychologist, 11(3), 46-48.

Caprara, G. V., Alessandri, G., Eisenberg, N., Kupfer, A., Yamaguchi, S., Fukusawa, A., ..., Abela, J. R. (2012). The Positivity Scale. Psychological Assessment, 24(3), 701-712. https://doi.org/10.1037/a0026681

Caprara, G. V., Fagnani, C., Alessandri, G., Steca, P., Gigantesco, A., Cavalli-Sforza, L., Stazi, M. A. (2009). Human optimal functioning. The genetics of positive orientation towards self, life, and the future. Behaviour Genetics, 39, 277-284. https://doi.org/10.1007/s10519-009-9267-y

Ciborowska, H., Rudnicka, A. (2007). Dietetyka. Żywienie zdrowego i chorego człowieka. Warszawa: Wydawnictwo Lekarskie PZWL. 
Cieciuch, J. (2013). Pomiar wartości w zmodyfikowanym modelu Shaloma Schwartza. Psychologia Społeczna, 8 1(24), 22-41.

Cieciuch, J., Zaleski, Z. (2011). Polska adaptacja Portretowego Kwestionariusza Wartości Shaloma Schwartza. Czasopismo Psychologiczne, 17(2), 251-262.

Ding, C., Lim, L. L., Xu, L., Shan Kong, A. P. (2018). Sleep and obesity. Journal of Obesity \& Metabolic Syndrome, 27(1), 4-24. https://doi.org/10.7570/jomes.2018.27.1.4

Gajalakshmi, V., Lacey, B., Kanimozhi, V., Sherliker, P., Peto, R., Lewington, S. (2018). Body-mass index, blood pressure, and cause-specific mortality in India: A prospective cohort study of 500810 adults. The Lancet Global Health, 6(7), e787-e794. https://doi.org/10.1016/S2214-109X(18)30267-5

González, K., Fuentes, J., Márquez, J. L. (2017). Physical inactivity, sedentary behavior and chronic diseases. The Korean Academy of Family Medicine, 38(3), 111-115. https://doi.org/10.4082/kjfm.2017.38.3.111

Grzymisławski, M., Gawęcki, J. (red.). (2012). Żywienie człowieka zdrowego i chorego. Warszawa: Wydawnictwo Lekarskie PZWL.

Guthold, R., Stevens, G. A., Riley, L. M., Bull, F. C. (2018). Worldwide trends in insufficient physical activity from 2001 to 2016: A pooled analysis of 358 population-based surveys with 1,9 million participants. The Lancet Glob Health, 6(10), e933-e1044. https://doi.org/10.1016/S2214-109X(18)30357-7

Jarosz, M. (red.). (2017). Normy żywienia dla populacji Polski. Warszawa: Instytut Żywności i Żywienia.

Kęska, O., Bargiel-Matusiewicz, K. (2018). Kulturowy kontekst stylu życia osób z cukrzycą typu 2 ze szczególnym uwzględnieniem wiedzy na temat choroby oraz wyborów żywieniowych. W: J. Kowalska, R. Dziurla, K. Bargiel-Matusiewicz (red.), Kultura a zdrowie i niepetnosprawność (s. 13-30). Warszawa: Wydawnictwo Uniwersytetu Warszawskiego.

Kim, N. H., Lee, J., Kim, T. J., Kim, N. H., Choi, K. M., Baik, S. H., ..., Kim, S. G. (2015). Body Mass Index and mortality in the general population and in subjects with chronic disease in Korea: A nationwide cohort study (2002-2010). PLOS ONE, 10(10), e0139924. https://doi.org/10.1371/journal.pone.0139924

Kłosiewicz-Latoszek, L. (2009). Zalecenia żywieniowe w prewencji chorób przewlekłych. Problemy Higieny i Epidemiologii, 90(4), 447-450.

Kupcewicz, E., Szypulska, A., Doboszyńska, A. (2019). Positive orientation as a predictor of health behavior during chronic diseases, settings. International Journal of Environmental Research and Public Health, 16(18), 3408. https:/doi.org/10.3390/ ijerph16183408

Leal Neto, J., Barbosa, A. R., Meneghini, V. (2016). Diseases and chronic health conditions, multimorbidity and body mass index in older adults. Revisita Bra- 
sileira de Cineantropometria e Desempenho Humano, 18(5), 510-519. https://doi. org/10.5007/1980-0037.2016v18n5p509

Łaguna, M., Oleś, P., Filipiuk, D. (2011). Orientacja pozytywna i jej pomiar: Polska adaptacja Skali Orientacji Pozytywnej. Studia Psychologiczne, 49(4), 47-54.

Łukasik, I. M., Witek, A. (2018). Nastawienie na sukces w kontekście pozytywnej orientacji i poczucia własnej skuteczności. Annales Universitatis Mariae Curie-Skłodowska, sectio J - Paedagogia-Psychologia, 31(2), 301-312. http://dx.doi. org/10.17951/j.2018.31.2.301-312

Marques, A., Santos, T., Martins, J., Gaspar de Matos, M., Valeiro, M. G. (2018). The association between physical activity and chronic diseases In European adults. European Journal of Sport Science, European Journal of Sport Science, 18(1), 140-149. https://doi.org/10.1080/17461391.2017.1400109

Petrović, V. (2010). Positive psychology and positive orientation. Exercise and Quality of Life, 2(2), 21-30. https://doi.org/10.1007/s11482-017-9508-9

Piercy, K. L., Troiano, R. P., Ballard, R. M., Carlson, S. A., Fulton, J. E., Galuska, D. A., ..., Olson, R. D. (2018). The physical activity guidelines for Americans. JAMA, 320(19), 2020-2028. https://doi.org/10.1001/jama.2018.14854

Pitkala, K. H., Laakkonen, M. L., Strandberg, T. E., Tilvis, R. S. (2004). Positive life orientation as a predictor of 10-year outcome in an aged population. Journal of Clinical Epidemiology, 57(4), 409-414. https://doi.org/10.1016/j.jclinepi.2003.07.013

Sagiv, L., Roccas, S., Cieciuch, J., Schwartz, S. H. (2017). Personal values in human life. Nature Human Behaviour, 1(9), 630-639. https://doi.org/10.1038/s41562-017-0185-3

Schwartz, S. H. (2006). Basic human values: Theory, measurement, and applications. Revue Française de Socjologie, 47(4), 929-968. https://doi.org/10.3917/rfs.474.0929

Schwartz, S. H. (2009). Basic values: How they motivate and inhibit prosocial behavior. W: M. Mikulincer, P. Shaver (red.), Herzliya symposium on personality and social psychology, t. 1 (s. 221-241). Waszyngton: American Psychological Association Press. Schwartz, S. H., Cieciuch, J., Vecchione, M., Davidov, E., Fischer, R., Beierlein, C., ..., Konty, M. (2012). Refining the theory of basic individual values. Journal of Personality and Social Psychology, 103(4), 663-688. https://doi.org/10.1037/a0029393

Schwartz, S. H., Melech, G., Lehrnami, A., Burgess, S., Harris, M., Owens, V. (2001). Extending the cross-cultural validity of the theory of basic human values with a different method of measurement. Journal of Cross-Cultural Psychology, 32(5), 519-542. https://doi.org/10.1177/0022022101032005001

Seligman, M. E. P., Csikszentmihalyi, M. (2000). Positive psychology: An introduction. American Psychologist, 55(1), 5-14. https://doi.org/10.1037/0003-066X.55.1.5 
Sortheix, F. M., Schwartz, S. H. (2017). Values that underlie and undermine well-being: Variability across countries. European Journal of Personality, 31(2), 187-201. https://doi.org/10.1002/per.2096

Sullivan, P. W., Morrato, E. H., Ghushchyan, V., Wyatt, H. R., Hill, J. O. (2005). Obesity, inactivity, and the prevalence of diabetes and diabetes-related cardiovascular comorbidities in the U.S., 2000-2002. Diabetes Care, 28(7), 1599-1603. https:// doi.org/10.1161/CIRCULATIONAHA.106.171016

Tekeş, B., Üzümcüoğlu, Y., Hoe, C., Özkan, T. (2018). The relationship between Hofstede's cultural dimensions, Schwartz's cultural values, and obesity. Psychological Reports, 122(3), 968-987. https://doi.org/10.1177/0033294118777965

The Global BMI Mortality Collaboration. (2016). Body-mass index and all-cause mortality: Individual-participant-data meta-analysis of 239 prospective studies in four continents. Lancet, 388(10046), 776-786. https://doi.org/10.1016/S01406736(16)30175-1

Trzebińska, E. (2008). Psychologia pozytywna. Warszawa: Wydawnictwa Akademickie i Profesjonalne.

Von Ruesten, A., Weikert, C., Fietze, I., Boeing, H. (2012). Association of sleep duration with chronic diseases in the European Prospective Investigation into Cancer and Nutrition (EPIC)-Potsdam study. PLoS One, 7(1), e30972. https://doi.org/10.1371/ journal.pone.0030972.g001

Wang, Y., Mei, H., Jiang, Y. R., Sun, W. Q., Song, Y. J., Liu, S. J., Jiang, F. (2015). Relationship between duration of sleep and hypertension in adults: A meta-analysis. Journal of Clinical Sleep Medicine, 11(9), 1047-1056. https://doi.org/10.5664/jcsm.5024

World Health Organization. (2010). Global recommendations on physical activity for health. Genewa: World Health Organization. Pobrane z: https://www.ncbi.nlm. nih.gov/books/NBK305057/

World Health Organization. (2015). Obesity and overweight. Fact sheet $N^{\circ} 311$. Genewa: World Health Organization.

Warburton, D. E. R., Bredin, S. S. D. (2017). Health benefits of physical activity: A systematic review of current systematic reviews. Current Opinion in Cardiology, 32(5), 541-556. https://doi.org/10.1503/cmaj.051351

Yen, Y., Chang, K., Tsai, M., Tseng, P., Lin, M., Wu, C., ..., Chen, C. (2018). Elevated body mass index is a risk factor associated with possible liver cirrhosis across different etiologies of chronic liver disease. Journal of the Formosan Medical Association, 117(4), 268-275. https://doi.org/10.1016/j.jfma.2017.09.002 

AnNa OlejNiCZAK-SEROWIEC (iD) https://orcid.org/0000-0002-7590-8334 Dorota RutKowsKA (iD) https://orcid.org/0000-0002-4789-7578 Wydział Psychologii, Uniwersytet Warszawski

\section{Przyjmowanie perspektywy społecznej obniża,} a obracanie mentalne podnosi poziom wykonania zadania wymagającego przyjmowania perspektywy poznawczej Social perspective taking decreases and mental rotation increases performance in cognitive perspective taking task

Sposób cytowania: Olejniczak-Serowiec, A., Rutkowska, D. (2021). Przyjmowanie perspektywy społecznej obniża, a obracanie mentalne podnosi poziom wykonania zadania wymagającego przyjmowania perspektywy poznawczej. W: M. Huflejt-Łukasik, A. Pluta (red.), Mechanizmy psychologiczne i społeczne warunkujące formułowanie ocen oraz podejmowanie działań (s. 121-138). Warszawa: Wydawnictwo Liberi Libri. https://doi.org/10.47943/lib.9788363487553.rozdzial06

Badanie przedstawione w artykule było finansowane z funduszy Wydziału Psychologii Uniwersytetu Warszawskiego na badania statutowe DSM 114211/2016.

Korespondencję dotyczącą artykułu prosimy kierować do Anny Olejniczak-Serowiec, Wydział Psychologii, Uniwersytet Warszawski, ul. Stawki 5/7, 00-183 Warszawa, e-mail: anna.olejniczak@psych.uw.edu.pl 


\section{Streszczenie}

Przyjmowanie perspektywy poznawczej i zdolność do obracania mentalnego to konstrukty zakorzenione w podobnych procesach poznawczych. Przyjmowanie perspektywy społecznej to zjawisko, którego pozytywnego wpływu na wzajemne zrozumienie uczestników interakcji dowiedziono $\mathrm{w}$ wielu badaniach. Badanie przedstawione $\mathrm{w}$ artykule zaprojektowano w celu weryfikacji hipotez dotyczących znaczenia tych zjawisk w funkcjonowaniu kierowców. W takich zadaniach, wymagających dokonywania w wyobraźni operacji przestrzennych, jak prowadzenie samochodu, sama skłonność do spojrzenia na sytuację z punktu widzenia innej osoby może nie być wystarczającą, jeśli nie jest poparta poznawczą zdolnością do obracania przestrzeni w wyobraźni. Przeprowadzono eksperyment, w którym zapraszano osoby badane do wykonania zadania będącego zmodyfikowaną wersją "gry” Keysara. Mierzono również zdolność do obracania mentalnego oraz skłonność do spontanicznego przyjmowania perspektywy społecznej. Wyniki eksperymentu wskazują, że poziom wykonania zadania wymagającego przyjmowania perspektywy poznawczej ma związek zarówno ze spontaniczną skłonnością do przyjmowania perspektywy społecznej, jak i zdolnością do obracania mentalnego. Każda $\mathrm{z}$ tych zmiennych wiąże się jednak z poziomem wykonania zadania opartego na przyjmowaniu perspektywy poznawczej w inny sposób. Sytuacyjnie wzbudzane przyjmowanie perspektywy i zdolność do obracania mentalnego wiążą się pozytywnie $\mathrm{z}$ wykonaniem zadania, natomiast korelacja poziomu wykonania zadania - ze skłonnością do spontanicznego przyjmowania perspektywy społecznej jest negatywna.

Słowa kluczowe:kierowcy, obracanie mentalne, przyjmowanie perspektywy poznawczej, przyjmowanie perspektywy społecznej, zadanie Keysara 


\begin{abstract}
Cognitive perspective taking and mental rotation are constructs rooted in similar processes. Social perspective taking has been proved to facilitate actors' mutual understanding. The current work is designed to verify how the three may interplay in drivers. In tasks involving spatial mental operations, the sheer propensity to look at the situation from the other's standpoint might not be enough unless supported by the skill to rotate the space in one's mind. In the experiment, participants were invited to play Keysar task-based game. We also measured mental rotation abilities and the propensity to take others' perspective spontaneously. The results show that the efficacy in cognitive perspective taking task is related to both social perspective taking and mental rotation capability, although they affect participants' performance differently. Situationally induced perspective taking and mental rotation ability enhance participant's performance, while it correlates negatively with the propensity for social perspective taking.
\end{abstract}

Keywords: drivers, mental rotation, cognitive perspective taking, social perspective taking, Keysar task

Przyjmowanie perspektywy społecznej (social perspective taking) jest definiowane jako „skłonność do spontanicznego przyjmowania psychologicznego punktu widzenia innej osoby w życiu codziennym" (Davis, 1999, s. 71). Niektórzy badacze wskazują na rozróżnienie dwóch sposobów przyjmowania perspektywy jako „wyobrażania sobie rzeczywistości z punktu widzenia innej osoby lub wyobrażania sobie siebie na miejscu innej osoby" (Galinsky, $\mathrm{Ku}$, Wang, 2005, s. 110). Wyobrażanie sobie rzeczywistości z punktu widzenia innej osoby (imagine-other) oraz wyobrażanie sobie siebie na miejscu innej osoby (imagine-self) mogą prowadzić do innych konsekwencji pod względem stopnia, w jakim aktywizują one reprezentację Ja (por. Davis i in., 2004), a także odmiennie oddziałują na motywację do zachowań prospołecznych (por. Myers, Laurent, Hodges, 2014). Według niektórych badaczy (Maner i in., 2002) spo- 
łeczne przyjmowanie perspektywy to proces wyobrażania sobie, co inna osoba czuje w danej sytuacji. Według innych (np. Oswald, 1996, 2002) proces taki oznacza afektywne przyjmowanie perspektywy społecznej (affective perspective taking), które należy odróżnić od poznawczego przyjmowania perspektywy społecznej (cognitive perspective taking), rozumianego jako wyobrażanie sobie, co inna osoba myśli w danej sytuacji. Rezultaty badań wskazują, że każdy z tych procesów może wywierać inny wpływ na zachowania prospołeczne (Oswald, 1996, 2002), a także że wiążą się one z aktywnością innych struktur neuroanatomicznych (Hyens, Baird, Grafton, 2006).

Przyjmowanie perspektywy społecznej przez wielu badaczy operacjonalizowane jest jako stan wzbudzany sytuacyjnie za pomocą procedur eksperymentalnych (np. Davis i in., 2004; Galinsky i in., 2005). Zarazem dostępność cudzej perspektywy może być traktowana jako względnie stała właściwość podmiotu (Białek, 2010), która umożliwia zrozumienie i przewidywanie zachowań innych ludzi w codziennych sytuacjach (Converse, Epley, Lin, Keysar, 2008). Zgodnie $\mathrm{z}$ takim stanowiskiem ludzie różnią się między sobą poziomem indywidualnej, dyspozycyjnej skłonności do przyjmowania perspektywy innych, a pomiaru tych różnic można dokonać przy zastosowaniu technik kwestionariuszowych (np. Davis, 1994; Gehlbach, Brinkworth, 2012; Gehlbach, Brinkworth, Wang, 2012).

Niezależnie od tego, czy ma ono charakter afektywny, czy poznawczy, czy polega na wyobrażaniu sobie rzeczywistości z cudzego punktu widzenia, czy na wyobrażaniu sobie siebie w sytuacji innej osoby, czy stanowi doraźnie aktywizowany stan, czy jest przejawem względnie trwałych właściwości jednostki, przyjmowanie perspektywy jest procesem angażującym zasoby poznawcze (Epley, Keysar, Van Boven, Gilovich, 2004; Epley, Morewedge, Keysar, 2004) i wymagającym osiągnieć rozwojowych, do których należy decentracja poznawcza (Piaget, Inhelder, 1993). Decentracja poznawcza pojawia się zwykle między 7. a 10. rokiem życia i pozwala wyjść poza egocentryczny punkt widzenia oraz zrozumieć, że rzeczywistość może wyglądać nieco inaczej, niż wygląda ona z punktu widzenia podmiotu. Rolę przyjmowania perspektywy w rozwoju społecznym jednostki potwierdzają doniesienia z badań neuropsychologicznych, wskazujące na wzrost dyspozycyjnej skłonności do przyjmowania perspektywy wraz z rozwojem środkowego zakrętu czołowego (Pfeifer i in., 2009) związanego $\mathrm{z}$ jakością funkcjonowania społecznego. Przyjmowanie perspektywy stanowi podstawę dla rozwoju inteligencji społecznej i dla funkcjonowania społecznego (Baron-Cohen, Leslie, Frith, 1985). 
Relatywnie niewiele badań poświęcono trafności, z jaką ludzie przyjmujący cudzą perspektywę „odczytują” punkt widzenia innej osoby. Rezultaty tych badań dowodzą jednak, że trafność ta często nie jest wysoka, mimo że towarzyszyć jej może silna subiektywna pewność co do własnych umiejętności odgadywania myśli i odczuć innych osób (Eyal, Epley, 2018; Realo i in., 2003; van der Heiden, Scherpiet, Konicar, Birbaumer, Veit, 2013). Mimo relatywnie niskiej trafności, korzystny wpływ przyjmowania perspektywy na funkcjonowanie społeczne jest zjawiskiem dobrze udokumentowanym. Rezultaty badań pokazują na przykład, że przyjmowanie perspektywy redukuje skłonność do stereotypowego spostrzegania i dokonywania powierzchownych ocen innych osób (np. Bilewicz, 2009; Galinsky, Moskowitz, 2000; Ku, Wang, Galinsky, 2010). Istnieją również rezultaty wskazujące na wzrost zachowań związanych z wartościami takimi jak sprawiedliwość pod wpływem przyjmowania perspektywy (Berndsen, McGarty, 2012; Juujarvia, Myyry, Pessoa, 2010). Mimo wielu korzyści, jakie dla życia społecznego może przynieść przyjmowanie perspektywy innych ludzi, sama chęć do spojrzenia na rzeczywistość z punktu widzenia innej osoby w zadaniu wymagającym obcowania ze strukturami przestrzennymi może okazać się niewystarczająca, jeśli nie towarzyszy jej poznawcza zdolność do obracania spostrzeganej sceny w wyobraźni. Zdolność ta nazywana jest obracaniem mentalnym (Shepard, Metzler, 1988). Badania empiryczne dowodzą, że zdolność do obracania mentalnego ma wpływ na poziom wykonania zadań wymagających obcowania ze strukturami przestrzennymi (Stransky, Wilcox, Dubrowski, 2010).

Społeczne przyjmowanie perspektywy należy odróżnić od poznawczego przyjmowania perspektywy, odnoszącego się do percepcji wzrokowej (cognitive / perceptual perspective taking). To ostatnie definiuje się jako zdolność do wyobrażania siebie sceny lub obiektu z punktu widzenia innej osoby (Hegarty, Waller, 2004). Innymi słowy, poznawcze przyjmowanie perspektywy odnosi się do percepcji wzrokowej i polega na wyobrażeniu sobie, w jaki sposób spostrzega dany obiekt lub scenę osoba, która patrzy na nie z innej strony. Poznawcze przyjmowanie perspektywy w obszarze percepcji wzrokowej oraz obracanie mentalne mają ze sobą wiele wspólnego: obydwa procesy wymagają dokonywania transformacji przestrzeni w wyobraźni. Jednak w procesie poznawczego przyjmowania perspektywy to punkt widzenia podmiotu podlega transformacji, podczas gdy w procesie obracania mentalnego transformacji podlega obraz obiektu (Hegarty, Waller, 2004). Rezultaty badań wskazują, że wielkość dokonywanej transformacji (np. wielkość kąta, o jaki obracany jest 
obiekt lub scena) ma większy wpływ na poziom wykonania zadań wymagających przyjmowania perspektywy niż na poziom wykonania zadań wymagających obracania mentalnego (Kozhevnikov, Motes, Rasch, Blajenkova, 2006).

Do kategorii zachowań, które powinny angażować zdolność do obracania mentalnego oraz przyjmowanie perspektywy społecznej i poznawczej w obszarze percepcji wzrokowej należy prowadzenie pojazdów w ruchu drogowym. Tego rodzaju zachowania wymagają szybkiego i trafnego odzwierciedlenia w umyśle punktu widzenia innych uczestników ruchu drogowego. W związku z tym zaprojektowano badanie, w którym sprawdzano, czy w grupie kierowców zdolność do obracania mentalnego oraz skłonność do przyjmowania perspektywy społecznej wiążą się z szybkością i poprawnością wykonania zadania, które wymaga przyjmowania perspektywy poznawczej w odniesieniu do percepcji wzrokowej. Sformułowano poniższe hipotezy.

Hipoteza I: Sytuacyjne wzbudzenie przyjmowania perspektywy prowadzi do podwyższenia poziomu wykonania w zadaniu wymagającym przyjmowania perspektywy poznawczej.

Hipoteza II: Dyspozycyjna skłonność do spontanicznego przyjmowania perspektywy społecznej:

a) zwiększa poprawność wykonania zadania wymagającego przyjmowania perspektywy poznawczej, ponieważ uwrażliwia na odmienność punktu widzenia innych osób,

b) wydłuża czas wykonania zadania wymagającego przyjmowania perspektywy poznawczej, ponieważ redukuje zasoby poznawcze, które mogłyby być zainwestowane w poprawne wykonanie zadania wymagającego przyjmowania perspektywy w obszarze percepcji wzrokowej.

Hipoteza III: Poziom wykonania zadania wymagającego przyjmowania perspektywy poznawczej wzrasta wraz ze wzrostem zdolności do obracania mentalnego.

Hipoteza IV: Sytuacyjne wzbudzenie przyjmowania perspektywy może kompensować deficyty w zakresie zdolności do obracania mentalnego przy wykonywaniu zadania wymagającego przyjmowania perspektywy poznawczej. 


\section{Metoda}

\section{Osoby badane, schemat i procedura badania}

W badaniu wzięło udział 60 kierowców amatorów posiadających prawo jazdy kategorii $\mathrm{B}$, w tym 30 mężczyzn i 30 kobiet. Wiek osób badanych zawierał się w przedziale $20-51$ lat $(M=32,61 ; S D=8,59)$. Uczestnicy badania zostali zrekrutowani za pośrednictwem ogłoszeń na portalach internetowych. Zaprojektowano eksperyment w schemacie międzygrupowym. Osoby badane podzielono losowo na dwie grupy, kontrolną i eksperymentalną, z zachowaniem równoliczności pod względem płci w każdej z grup (15 mężczyzn i 15 kobiet). W grupie eksperymentalnej za pomocą fragmentu instrukcji sytuacyjnie wzbudzano przyjmowanie perspektywy, zaś w grupie kontrolnej instrukcja nie zachęcała do przyjmowania perspektywy innych ludzi. W obu grupach wykorzystano także autorski kwestionariusz do pomiaru nasilenia indywidualnej, dyspozycyjnej skłonności do spontanicznego przyjmowania perspektywy społecznej oraz zadania testowe, służące do pomiaru zdolności do obracania mentalnego.

Po przybyciu do laboratorium uczestnicy byli informowani, że badanie ma na celu obserwację przebiegu interakcji społecznych. Następnie zapoznawali się z procedurą i udzielali ustnej zgody na udział w badaniu oraz akceptacji przedstawionych warunków udziału wraz z możliwością rezygnacji w dowolnym momencie bez podania przyczyny. Po przydzieleniu do jednego z warunków badania osoby badane najpierw wykonywały zadanie wymagające przyjmowania perspektywy poznawczej. Następnie rozwiązywały one zadania testowe, które stanowiły narzędzie pomiaru zdolności do obracania mentalnego. Na koniec badani wypełniali kwestionariusz, który mierzył nasilenie indywidualnej skłonności do spontanicznego przyjmowania perspektywy społecznej oraz ankietę demograficzną. Po zakończeniu procedury badawczej następowało odkłamanie celu badania i wypłata wynagrodzenia za udział.

\section{Narzędzia pomiaru zmiennych}

Poziom wykonania zadania wymagającego przyjmowania perspektywy poznawczej mierzono za pomocą "gry” Keysara (Keysar, Barr, Balin, Brauner, 2000). Zadanie to polega na wykonaniu serii instrukcji poprzez przesuwanie 
przedmiotów po składającym się z półek regale. Na potrzeby badania zaadaptowano zadanie w formie gry komputerowej, w której odrębnym półkom regału odpowiadały kwadratowe pola na planszy (rysunek 1). Każdego z uczestników zapraszano do gry komputerowej z fikcyjnym partnerem. Informowano, że partner znajduje się w drugim pokoju i widzi obraz planszy gry z drugiej strony. Plansza została skonstruowana w taki sposób, że część pól nie była widoczna dla osoby badanej (czarne kwadraty na rysunku 1), część zaś była widoczna tylko dla osoby badanej, ale nie była widoczna dla jej fikcyjnego partnera (pola z szarym tłem na rysunku 1). Pozostałe pola były widoczne zarówno dla osoby badanej, jak i dla jej fikcyjnego partnera w grze (pola $\mathrm{z}$ białym tłem na rysunku 1).
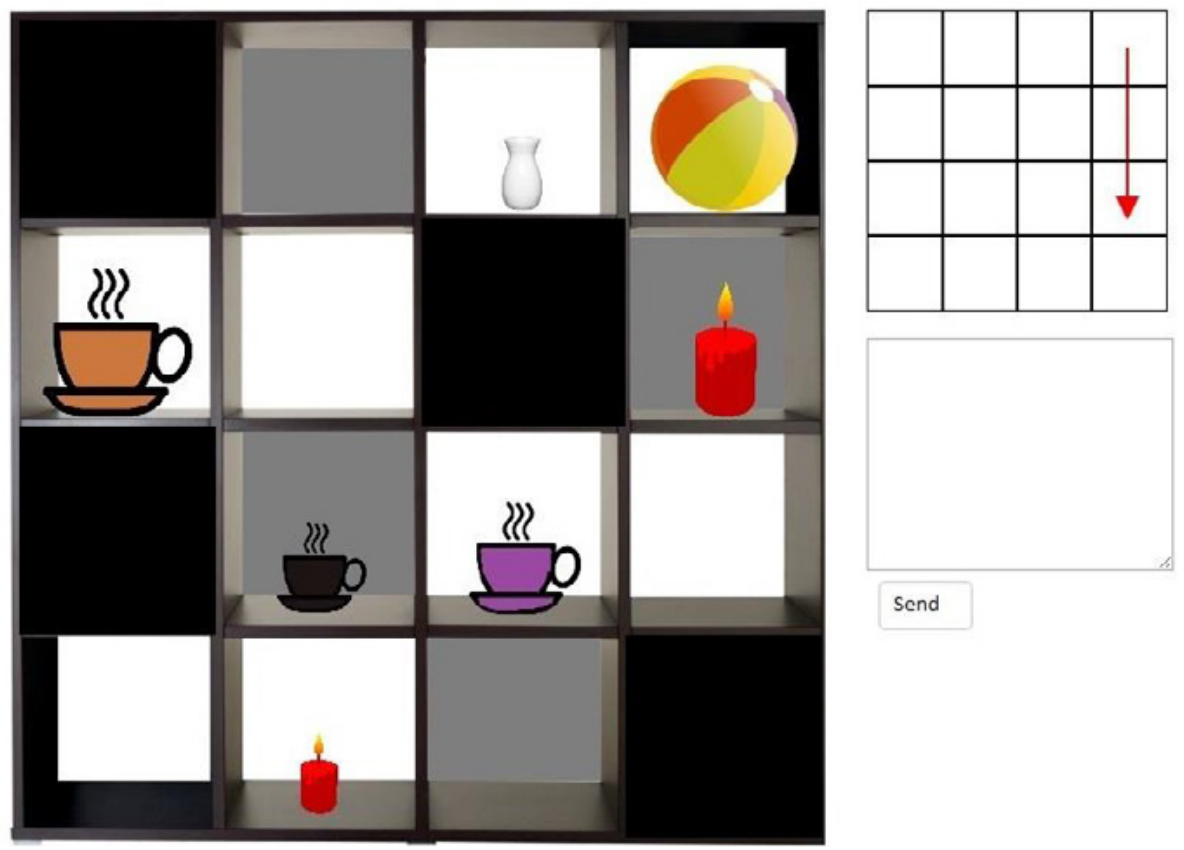

Rysunek 1. Ekran zadania eksperymentalnego.

W czasie gry badani wykonywali naprzemiennie dwa rodzaje operacji: przesuwali przedmioty na polecenie fikcyjnego partnera oraz przekazywali mu polecenia dotyczące przesuwania przedmiotów. W rzeczywistości każdy badany otrzymywał ten sam, wystandaryzowany zestaw instrukcji. Podczas 
udzielania instrukcji drugiemu graczowi badany widział schemat planszy, na której czerwoną kropką zaznaczone było położenie przedmiotu, który miał zostać przesunięty przez drugiego gracza, a czerwoną strzałką wskazywano kierunek przesunięcia. Grot strzałki wyznaczał pole na planszy („półkę”), na której przedmiot miał się znaleźć po przesunięciu (por. rysunek 1). Podczas wykonywania przez osobę badaną operacji polegającej na przesuwaniu przedmiotów, instrukcja od partnera gry wyświetlała się w centrum ekranu. Po zapoznaniu się z instrukcją badany potwierdzał gotowość do wykonania operacji poprzez naciśnięcie przycisku „Dalej”, co powodowało zniknięcie instrukcji. Aby przesunąć obiekt, należało wskazać go za pomocą myszy, a następnie przeciągnąć i upuścić na właściwym polu. Po wykonaniu zadania badany naciskał przycisk „Dalej”, aby przejść do następnego ekranu. Od czasu do czasu podczas przejścia pomiędzy ekranami badanemu ukazywał się ekran oczekiwania z informacją, że musi poczekać, aż drugi gracz wykona swoje zadanie.

Zadanie składało się z fazy treningowej, w której jednokrotnie przesuwano obiekt i jednokrotnie formułowano instrukcję dla partnera gry, oraz $\mathrm{z}$ fazy testowej, w której występowało 10 operacji polegających na przesuwaniu obiektów i 10-krotne udzielanie instrukcji fikcyjnemu partnerowi. Operacje przesuwania obiektów oraz udzielanie instrukcji wykonywano naprzemiennie. Wskaźnikiem poziomu wykonania zadania były liczba prawidłowo wykonanych przesunięć obiektów (poprawność wykonania), średni czas przesuwania obiektu oraz średni czas czytania instrukcji pochodzących od fikcyjnego partnera. Im wyższa poprawność i krótszy czas, tym wyższy poziom wykonania zadania.

Manipulacji eksperymentalnej przyjmowaniem perspektywy dokonano za pomocą instrukcji do badania. Niezależnie od grupy badawczej każdy z uczestników otrzymywał instrukcję mówiącą o tym, że drugi gracz widzi planszę przedstawiającą regał, jakby znajdował się po jego drugiej stronie. Następnie proszono uczestników o zwrócenie uwagi na fakt, że niektóre pola nie są widoczne dla drugiego gracza, a także na to, że pola niewidoczne dla samego badanego są widoczne dla jego partnera. W warunku eksperymentalnym dodatkowo proszono badanych, aby spróbowali wyobrazić sobie planszę z perspektywy drugiego gracza i postarali się wyobrazić sobie, jak wygląda ona $\mathrm{z}$ jego punktu widzenia. W grupie kontrolnej pomijano tę część instrukcji.

Do pomiaru indywidualnej dyspozycyjnej skłonności do spontanicznego społecznego przyjmowania perspektywy społecznej wykorzystano autorski kwestionariusz Rozważania. Kwestionariusz składa się 15 pozycji. Każda 
z nich zawiera opis sytuacji, która może wystąpić w ruchu drogowym (np. „Wyjeżdżający tyłem z parkingu samochód zablokował Ci drogę. Myślisz sobie...") oraz dwa stwierdzenia przyporządkowane do tego opisu. Jedno z nich odzwierciedla przyjmowanie perspektywy poprzez wyobrażenie sobie punktu widzenia innego uczestnika ruchu drogowego (np. „Zaparkowany obok samochód mógł zasłonić temu kierowcy drogę, i kierowca liczył na to, że inni się zatrzymają, kiedy zacznie cofać"). Drugie stwierdzenie odpowiada przyjmowaniu perspektywy przez wyobrażenie sobie siebie na miejscu innego uczestnika ruchu drogowego (np. „Na jego miejscu też bym pewnie wymusił/a pierwszeństwo przy tak ograniczonej widoczności i takim dużym ruchu"). Zadaniem badanego jest określenie, na ile każde z zaproponowanych twierdzeń jest podobne do tego, co sam pomyślałby w podobnej sytuacji. Do udzielania odpowiedzi służy 5-stopniowa skala, gdzie 1 oznacza zupełnie niepodobne, a 5 - zupetnie podobne. Wynik w kwestionariuszu oblicza się jako sumę wszystkich odpowiedzi. Rzetelność skali zweryfikowano za pomocą współczynnika a Cronbacha, który wynosił 0,71. W badaniu pilotażowym nie zaobserwowano związku pomiędzy wynikiem w kwestionariuszu Rozważania a potrzebą aprobaty społecznej, mierzoną za pomocą skali Marlowa-Crowna $(r=-0,28 ; p>0,05 ; N=69)$.

Zdolność do obracania mentalnego mierzono za pomocą testu TRIT z baterii testów Test2Drive, seria IV Obserwator (Tarnowski, 2016). Test składający się z pięciu prób wykonywano na ekranie dotykowym. W każdej z prób badanemu wyświetlano obrazek przedstawiający w sposób schematyczny sytuację drogową na skrzyżowaniu. Na obrazku strzałką zaznaczano miejsce, w którym znajduje się obserwator - osoba badana. Osobę badaną proszono o wskazanie, jak dana sytuacja wygląda z punktu wskazanego strzałką. Poniżej każdego pytania znajdowało się sześć schematycznych obrazków stanowiących propozycje odpowiedzi, a zadaniem badanego było wskazanie wśród tych propozycji odpowiedzi właściwej. W teście uzyskiwano dwa wskaźniki wykonania: sumę poprawnych odpowiedzi oraz sumaryczny czas wykonania zadania. 


\section{WYNIKI}

\section{Sytuacyjne wzbudzenie przyjmowania perspektywy a wykonanie zadania wymagającego poznawczego przyjmowania perspektywy: weryfikacja hipotezy I}

Analiza testem $t$-Studenta dla pomiarów niezależnych wykazała, że w warunku eksperymentalnym, w którym instrukcja zachęcała do przyjmowania perspektywy partnera gry, osoby badane uzyskiwały w zadaniu wymagającym przyjmowania perspektywy poznawczej więcej punktów niż badani w grupie kontrolnej (odpowiednio: $M=3,47 ; S D=2,22$ i $M=2,23$; $S D=1,72 ; t=2,41$; $p<0,01)$. Nie zaobserwowano istotnych statystycznie różnic pomiędzy grupami w zakresie czasu wykonania zadania polegającego na przesuwaniu przedmiotów $(t=-1,12$; n.i. $)$ ani w zakresie czasu czytania instrukcji $(t=0,27$; n.i.).

Indywidualna skłonność do przyjmowania perspektywy społecznej a wykonanie zadania wymagającego przyjmowania perspektywy poznawczej: weryfikacja hipotezy lla

Analiza korelacji wykazała występowanie istotnego statystycznie, pozytywnego związku między skłonnością do spontanicznego przyjmowania perspektywy społecznej innych uczestników ruchu drogowego a czasem czytania instrukcji $(r=0,43 ; p<0,001)$ oraz czasem przesuwania przedmiotów $(r=0,24$; $p<0,05)$ w zadaniu wymagającym poznawczego przyjmowania perspektywy Zaobserwowano także istotny statystycznie, lecz negatywny związek między poziomem indywidualnej dyspozycyjnej skłonności do spontanicznego przyjmowania perspektywy społecznej innych uczestników ruchu drogowego a liczbą poprawnych odpowiedzi w zadaniu wymagającym poznawczego przyjmowania perspektywy $(r=-0,26 ; p<0,05)$. W tabeli 1 przedstawiono wyniki analizy korelacji. 
Tabela 1

Współczynniki korelacji r-Pearsona w przebadanej próbie

\begin{tabular}{|c|c|c|c|c|c|c|}
\hline Miara & 1 & 2 & 3 & 4 & 5 & 6 \\
\hline $\begin{array}{l}\text { 1. Wynik w kwestionariuszu } \\
\text { Rozważania }\end{array}$ & - & & & & & \\
\hline 2. Wynik w teście Obserwator & $-0,31^{*}$ & - & & & & \\
\hline $\begin{array}{l}\text { 3. Czas wykonania w teście } \\
\text { Obserwator }\end{array}$ & $0,29^{*}$ & $-0,09$ & - & & & \\
\hline 4. Wynik w grze komputerowej & $-0,26^{*}$ & $0,33^{* *}$ & 0,04 & - & & \\
\hline $\begin{array}{l}\text { 5. Czas przesuwania przedmiotów } \\
\text { w grze komputerowej }\end{array}$ & $0,24^{*}$ & $-0,21$ & $-0,44^{* * *}$ & 0,13 & - & \\
\hline $\begin{array}{l}\text { 6. Czas czytania instrukcji w grze } \\
\text { komputerowej }\end{array}$ & $0,43^{* * *}$ & $-0,46^{* * *}$ & $-0,31^{* *}$ & $-0,24^{*}$ & $0,57^{* * *}$ & - \\
\hline
\end{tabular}

${ }^{*} p<0,05 ;{ }^{* *} p<0,01 ;{ }^{* * *} p<0,001$.

Indywidualna skłonność do spontanicznego przyjmowania perspektywy społecznej a zdoIność do obracania mentalnego: weryfikacja hipotezy Illb

Skłonność do spontanicznego przyjmowania perspektywy społecznej innych uczestników ruchu drogowego korelowała istotnie statystycznie i pozytywnie z czasem wykonania testu zdolności do obracania mentalnego oraz negatywnie $\mathrm{z}$ wynikiem uzyskanym $\mathrm{w}$ tym teście (odpowiednio: $r=0,29 ; p<0,05$ oraz $r=-0,31 ; p<0,05$; por. tabela 1$)$.

\section{Obracanie mentalne a wykonanie zadania wymagającego przyjmowania perspektywy poznawczej: weryfikacja hipotezy III}

Wyniki w teście obracania mentalnego okazały się pozytywnie i istotnie statystycznie związane $\mathrm{z}$ wynikami uzyskanymi w zadaniu wymagającym poznawczego przyjmowania perspektywy $(r=0,33$; $p<0,01)$ oraz negatywnie istotnie związane $\mathrm{z}$ czasem czytania instrukcji w tym zadaniu $(r=-0,46$; $p<0,001$; por. tabela 1). 


\section{Obracanie mentalne i przyjmowanie perspektywy społecznej a wykonanie zadania wymagającego przyjmowania perspektywy poznawczej: weryfikacja hipotezy IV}

Na podstawie mediany rozkładu liczby poprawnych odpowiedzi $(M e=3,5)$ w zadaniu testowym Obserwator uczestników badania podzielono na dwie grupy różniące się poziomem zdolności do obracania mentalnego. Przeprowadzono porównania testem $t$-Studenta dla pomiarów niezależnych, w których analizowano wpływ manipulacji eksperymentalnej na wykonanie zadania wymagającego przyjmowania perspektywy poznawczej w grupach badanych, którzy różnili się poziomem zdolności do obracania mentalnego.

Badani, którzy uzyskali niższe wyniki w teście obracania mentalnego, wykonywali zadanie wymagające poznawczego przyjmowania perspektywy poprawniej w grupie, w której wzbudzano przyjmowanie perspektywy $(M=2,86 ; S D=1,79)$ niż w grupie kontrolnej $(M=1,75 ; S D=1,13 ; t=-2,05$; $p<0,05)$. Wśród badanych, którzy uzyskali w teście zdolności do obracania mentalnego wyniki powyżej mediany, nie zaobserwowano pod tym względem różnic pomiędzy warunkiem eksperymentalnym $(M=2,79 ; S D=2,12)$ a kontrolnym $(M=4 ; S D=2,48 ; t=-1,43$; n.i.). Nie zaobserwowano także istotnych statystycznie różnic pomiędzy grupą eksperymentalną a kontrolną w zakresie czasu przesuwania obiektów w zadaniu wymagającym przyjmowania perspektywy poznawczej ani wśród osób o niskich $(t=1,54 ;$ n.i.), ani wśród osób o wysokich $(t=0,18$; n.i.) wynikach w teście zdolności do obracania mentalnego. Różnice pomiędzy tymi grupami w zakresie czasu czytania poleceń wydawanych przez fikcyjnego partnera gry również nie osiągnęły poziomu istotności statystycznej (odpowiednio: $t=-0,26$; n.i. oraz $t=0,71$; n.i.).

\section{Podsumowanie}

W badaniu uzyskano następujące istotne statystycznie zależności:

(i) uczestnicy badania wykonywali zadanie wymagające poznawczego przyjmowania perspektywy poprawniej w grupie, w której wzbudzano przyjmowanie perspektywy instrukcją, niż w grupie kontrolnej, przy jednoczesnym braku różnic w czasie wykonywania tego zadania;

(ii) wyższy poziom indywidualnej skłonności do spontanicznego przyjmowania perspektywy innych uczestników ruchu drogowego wiązał 
się z niższą poprawnością i dłuższym czasem wykonania zadania wymagającego poznawczego przyjmowania perspektywy;

(iii) wyższy poziom skłonności do spontanicznego przyjmowania perspektywy innych uczestników ruchu drogowego wiązał się także z niższą poprawnością oraz dłuższym czasem wykonania zadań składających się na test zdolności do obracania mentalnego;

(iv) wyższa poprawność wykonania zadań składających się na test zdolności do obracania mentalnego była związana $\mathrm{z}$ wyższą poprawnością wykonania zadania wymagającego poznawczego przyjmowania perspektywy oraz z krótszym czasem czytania instrukcji do operacji składających się na to zadanie;

(v) osoby badane, które uzyskały niższe wyniki w teście zdolności do obracania mentalnego wykonywały zadanie wymagające poznawczego przyjmowania perspektywy poprawniej w grupie, w której wzbudzano przyjmowanie perspektywy niż w grupie kontrolnej.

\section{Dyskusja}

Wyniki przeprowadzonego eksperymentu wskazują, że skuteczność w zadaniu wymagającym przyjmowania perspektywy poznawczej w obszarze percepcji wzrokowej może zależeć zarówno od poziomu zdolności do obracania mentalnego, jak i od przyjmowania perspektywy społecznej. Wyższy poziom zdolności do obracania mentalnego wiązał się ze wzrostem poprawności wykonania zadań wymagających przyjęcia perspektywy w odniesieniu do percepcji wzrokowej, jak i zdawał się ułatwiać rozumienie instrukcji do poszczególnych operacji składających się na to zadanie, ponieważ sprzyjał skróceniu czasu poświęconego na ich czytanie. Rezultat ten wydaje się zrozumiały, ponieważ zarówno przyjmowanie perspektywy w zakresie percepcji wzrokowej, jak i obracanie mentalne wymagają transformowania spostrzeganych obiektów lub przestrzeni w umyśle. Jednak wyższy poziom indywidualnej, dyspozycyjnej skłonności do spontanicznego przyjmowania perspektywy społecznej wiązał się z obniżeniem sprawności (redukcją poprawności i wydłużeniem czasu) wykonania zadań wymagających przyjęcia perspektywy w obszarze percepcji wzrokowej. Taki kierunek zależności może wskazywać na to, że jednoczesne przyjmowanie perspektywy w odniesieniu do percepcji wzrokowej oraz do wyobrażania sobie odczuć i myśli innej osoby mogą zachodzić względem 
siebie konkurencyjnie. Przyjmowanie perspektywy stanowi bowiem proces angażujący poznawcze zasoby podmiotu (por. Epley, Keysar i in., 2004; Epley, Morewedge i in., 2004). Zaangażowanie zasobów w przyjmowanie perspektywy społecznej może ograniczać ich dostępność dla poznawczego przyjmowania perspektywy w odniesieniu do percepcji wzrokowej. U osób, które wykazują wyższą dyspozycyjną skłonność do spontanicznego przyjmowania perspektywy społecznej partnera interakcji, proces ten może być uruchamiany nawykowo, redukując tym samym możliwość angażowania poznawczego wysiłku w wyobrażanie sobie, jak widzi dany obiekt osoba, która patrzy nań z innej strony. Taka interpretacja uzyskanej zależności wydaje się uzasadniona w kontekście negatywnego związku skłonności do przyjmowania perspektywy społecznej $\mathrm{z}$ poziomem wykonania zadań testowych, mających na celu pomiar zdolności do obracania mentalnego, które - podobnie jak przyjmowanie perspektywy - angażuje zasoby poznawcze podmiotu.

Sytuacyjne wzbudzenie przyjmowania perspektywy sprzyjało poprawności wykonania zadania wymagającego odzwierciedlenia punktu widzenia innej osoby, przy czym wpływ instrukcji na poprawność wykonania tego zadania obserwowany był przede wszystkim w grupie osób o niższym poziomie zdolności do obracania mentalnego. Wart odnotowania jest fakt, że zastosowana jako manipulacja eksperymentalna instrukcja, która zachęcała do przyjmowania perspektywy partnera gry, nie precyzowała, czy uczestnicy mieli się koncentrować na myślach i uczuciach partnera, czy na tym, co widzi on na swoim monitorze. Uzyskane wyniki mogą sugerować, że manipulacja eksperymentalna stanowiła dla badanych bodziec nie tyle do przyjęcia perspektywy społecznej, ile do zaangażowania wysiłku w poznawcze odzwierciedlenie punktu widzenia partnera $\mathrm{w}$ obszarze percepcji wzrokowej. $\mathrm{W}$ takim przypadku mogła ona sprzyjać lepszemu wykonaniu zadania wymagającego poznawczego przyjmowania perspektywy w szczególności w tej grupie osób, które charakteryzowały się niższym poziomem zdolności do obracania mentalnego.

Rezultaty badania sugerują, że poprawne i szybkie reakcje kierowców w ruchu drogowym mogą być funkcją zarówno zdolności do obracania mentalnego, jak i zachęty do przyjmowania perspektywy poznawczej innych ludzi, którzy są użytkownikami dróg. Jednak przyjmowanie perspektywy społecznej, gdy jest aktywizowane nawykowo przez względnie stabilną skłonność podmiotu do spontanicznego przyjmowania punktu widzenia innych ludzi, wydaje się być czynnikiem, który potencjalnie może utrudniać kierowcom wykonywanie prawidłowych i szybkich reakcji w ruchu drogowym. 


\section{BiBLIOGRAFIA}

Baron-Cohen, S., Leslie, A. M., Frith, U. (1985). Does the autistic child have a „theory of mind"? Cognition, 21(1), 37-46. https://doi.org/10.1016/0010-0277(85)90022-8

Berndsen, M., McGarty, C. (2012). Perspective taking and opinions about forms of reparation for victims of historical harm. Personality and Social Psychology Bulletin, 38(10), 1316-1328. https://doi.org/10.1177/0146167212450322

Białek, A. (2010). Patrz gdzie patrzę. Psychologiczne aspekty podejmowania cudzej perspektywy. Kraków: Wydawnictwo Uniwersytetu Jagiellońskiego.

Bilewicz, M. (2009). Perspective taking and intergroup helping intentions: The moderating role of power relations. Journal of Applied Psychology, 39(12), 2779-2786. https:// doi.org/10.1111/j.1559-1816.2009.00548

Converse, B. A., Epley, N., Lin, S., Keysar, B. (2008). In the mood to get over yourself: Mood affects Teory-of-Mind use. Emotion, 8(5), 725-730. https://doi.org/10.1037/ a0013283

Davis, M. H. (1994). Empathy: A social psychological approach. Madison: Taylor $\&$ Francis.

Davis, M. H. (1999). Empatia. O umiejętności współodczuwania. Gdańsk: Gdańskie Wydawnictwo Psychologiczne.

Davis, M. H., Soderlund, T., Cole, J., Gadol, E., Kute, M., Myers, M., Weihing, J. (2004). Cognitions associated with attempts to empathize: How do we imagine the perspective of another. Personality and Social Psychology Bulletin, 30(12), 1625-1635. https://doi.org/10.1177/0146167204271183

Epley, N., Keysar, B., Van Boven, L., Gilovich, T. (2004). Perspective taking as egocentric anchoring and adjustment. Journal of Personality and Social Psychology, 87(3), 327-339. https://doi.org/10.1037/0022-3514.87.3.327

Epley, N., Morewedge, C. K., Keysar, B. (2004). Perspective taking in children and adults: Equivalent egocentrism but differential correction. Journal of Experimental Social Psychology, 40(6), 760-768. https://doi.org/10.1016/j.jesp.2004.02.002

Eyal, T., Epley, N. (2018). Perspective mistaking: Accurately understanding the mind of another requires getting perspective, not taking perspective. Journal of Personality and Social Psychology, 114(14), 547-571. https://doi.org/10.1037/pspa0000115

Galinsky, A. D., Ku, G., Wang, C. S. (2005). Perspective taking and self-other overlap: Fostering social bonds and facilitating social coordination. Group Process and Intergroup Relations, 8(2), 109-124. https://doi.org/10.1177/1368430205051060

Galinsky, A. D., Moskowitz, G. B. (2000). Perspective-taking: Decreasing stereotype expression, stereotype accessibility, and in-group favoritism. Journal of Personality and Social Psychology, 78(4), 708-724. https://doi.org/10.1037/0022-3514.78.4.708 
Gehlbach, H., Brinkworth, M. E. (2012). The social perspective taking process: Strategies and sources of evidence in taking another's perspective. Teachers College Record, 114(1), 226-254.

Gehlbach, H., Brinkworth, M. E., Wang, M.-T. (2012). The social perspective taking process: What motivates individuals to take another's perspective. Teachers College Record, 114(1), 197-225.

Hegarty, M., Waller, D. (2004). A dissociation between mental rotation and perspective-taking. Intelligence, 32, 175-191. https://doi.org/10.1016/j.intell.2003.12.001

Hyens, C. A., Baird, A. A., Grafton, S. T. (2006). Differential role of the orbital frontal lobe in emotional versus cognitive perspective-taking. Neuropsychologia, 44, 374-383. https://doi.org/10.1016/j.neuropsychologia.2005.06.011

Juujarvia, S., Myyry, L., Pessoa, K. (2010). Does care reasoning make a difference? Relations between care, justice and dispositional empathy. Journal of Moral Education, 39(4), 469-489. https://doi.org/10.1080/03057240.2010.521381

Keysar, B., Barr, D. J., Balin, J. A., Brauner, J. S. (2000). Taking perspective in conversation: The role of mutual knowledge in comprehension. Psychological Science, 11(1), 32-38. https://doi.org/10.1111/1467-9280.00211

Kozhevnikov, M., Motes, M. A., Rasch, B., Blajenkova, O. (2006). Perspective-taking vs. mental rotation transformations. Applied Cognitive Psychology, 20, 397-417. https://doi.org/10.1002/acp.1192

Ku, G., Wang, C. S., Galinsky, A. D. (2010). Perception through a perspective-taking lens: Differential effects on judgment and behavior. Journal of Experimental Social Psychology, 46(5), 792-798. https://doi.org/10.1016/j.jesp.2010.04.001

Maner, J. K., Luce, C. L., Neuberg, S. L., Cialdini, R. B., Brown, S., Sagarin, B. J. (2002). The effects of perspective taking on motivations for helping: Still no evidence for altruism. Personality and Social Psychology Bulletin, 28(11), 1601-1610. https://doi. org/10.1177/014616702237586

Myers, M. W., Laurent, S. M., Hodges, S. D. (2014). Perspective taking instructions and self-other overlap: Different motives for helping. Motivation \& Emotion, 38(2), 224-234. https://doi.org/10.1007/s11031-013-9377-y

Oswald, P. A. (1996). The effects of cognitive and affective perspective taking on empathic concern and altruistic helping. The Journal of Social Psychology, 136(5), 613-623. https://doi.org/10.1080/00224545.1996.9714045

Oswald, P. A. (2002). The interactive effects of affective demeanor, cognitive processes, and perspective-taking focus on helping behavior. The Journal of Social Psychology, 142(1), 120-132. https://doi.org/10.1080/00224540209603890

Pfeifer, J. H., Oswald, I., Borotsky, L., Mazziotta, J. C., Iacobini, M., Dapretto, M. (2009). The social brain: Developmental changes in perspective-taking, interpersonal 
competence, and emphaty relate to longitudinal changes in brain activity as measures by fMRI. NeuroImage, 47(Supplement 1), S39-S41. https:/doi.org/10.1016/ S1053-8119(09)72043-9

Piaget, J., Inhelder, B. (1993). Psychologia dziecka. Wrocław: Siedmioróg.

Realo, A., Allik, J., Nolvak, A., Valk, R., Ruus, T., Schmidt, M., Eilola, T. (2003). Mind reading ability: Belief and performance. Journal of Research in Personality, 37, 420-445. https://doi.org/10.1016/s0092-6566(03)00021-7

Shepard, S., Metzler, D. (1988). Mental rotation: Effects of dimensionality of objects and type of task. Journal of Experimental Psychology: Human Perception and Performance, 14(1), 3-11. https://doi.org/10.1037//0096-1523.14.1.3

Stransky, D., Wilcox, L. M., Dubrowski, A. (2010). Mental rotation: Cross-task training and generalization. Journal of Experimental Psychology: Applied, 16(4), 349-360. https://doi.org/10.1167/8.6.650

Tarnowski, A. (2016). Test2Drive: podręcznik użytkownika. Siemianowice Śląskie: Kolumb.

van der Heiden, L., Scherpiet, S., Konicar, L., Birbaumer, N., Veit, R. (2013). Inter-individual differences in successful perspective taking during pain perception mediates emotional responsiveness in self and other: An fMRI study. NeuroImage, 65, 387-394. https://doi.org/10.1016/j.neuroimage.2012.10.003 
AnNa NowaK

MirosŁaWA Huflejt-ŁUKASIK (iD) https://orcid.org/0000-0001-7959-1760

Wydział Psychologii, Uniwersytet Warszawski

ADRIAN OKOŃ

CC Innovation

\section{Coaching jako narzędzie rozwoju zawodowego i osobistego naukowców \\ Coaching as a tool for professional and personal development of scientists}

Sposób cytowania: Nowak, A., Huflejt-Łukasik, M., Okoń, A. (2021). Coaching jako narzędzie rozwoju zawodowego i osobistego naukowców. W: M. Huflejt-Łukasik, A. Pluta (red.), Mechanizmy psychologiczne i społeczne warunkujace formułowanie ocen oraz podejmowanie działań (s. 139-158). Warszawa: Wydawnictwo Liberi Libri. https://doi.org/10.47943/lib.9788363487553.rozdzial07

Korespondencję dotyczącą artykułu prosimy kierować do Mirosławy Huflejt-Łukasik, Wydział Psychologii, Uniwersytet Warszawski, ul. Stawki 5/7, 00-183 Warszawa, e-mail: miroslawa.huflejt-lukasik@psych.uw.edu.pl 


\section{Streszczenie}

Celem rozdziału jest przedstawienie koncepcji coachingu jako metody wspierającej rozwój osób i organizacji, ze szczególnym uwzględnieniem coachingu dla naukowców. Przybliżone zostanie pojęcie coachingu oraz podstawowe informacje na temat tej metody wspierania rozwoju. Coaching powstał w organizacjach, by wspierać osoby w rozwoju zawodowym, choć aktualnie ma szerszy zakres i rozliczne specjalizacje. W tekście omówione zostaną charakterystyczne cechy, które pozwalają odróżnić coaching od pokrewnych metod pracy, a także specyfika coachingu w organizacjach. Następnie przytoczone zostaną dane empiryczne dotyczące skuteczności pracy w coachingu, oparte w głównej mierze o wyniki czterech metaanaliz podsumowujących efektywność coachingu. Ostatnia sekcja zawiera opis specyfiki środowiska naukowego. Przytoczone zostaną dane $\mathrm{z}$ literatury przedmiotu dotyczące wykorzystania coachingu przy wspieraniu liderów (dziekanów) dla zwiększenia efektywności procesu badawczego, przy planowaniu ścieżki kariery naukowej oraz w pracy dydaktycznej, nauczycieli. W tekście pokażemy szerszy kontekst i możliwości wykorzystania coachingu w środowisku naukowców. Opiszemy, w jaki sposób coaching może wesprzeć naukowców w różnych obszarach pracy zawodowej - związanych między innymi z rolą badacza, członka zespołu, kierownika jednostki, promotora, dydaktyka, osoby kierującej własną karierą naukową i prezentującej wyniki swojej pracy, a także przy realizacji celów osobistych. Na zakończenie wymienione zostaną wyzwania, jakie wiążą się z wprowadzaniem coachingu w środowisku naukowym.

Słowa kluczowe: coaching, coaching $\mathrm{w}$ organizacji, coaching $\mathrm{w}$ nauce

\section{Abstract}

The aim of the chapter is to present the concept of coaching as a method supporting the development of people and organizations, with particular emphasis on coaching for scientists. The concept of coaching and basic 
information about this method of supporting development will be introduced. Coaching was established in organizations to support people in their professional development, although it currently has a wider scope and numerous specializations. The text will discuss the characteristic features that make it possible to distinguish coaching from related work methods, as well as the specificity of coaching in organizations. Then, the empirical data on the effectiveness of coaching work will be presented, based mainly on the results of four meta-analyzes summarizing the effectiveness of coaching. The last section describes the specifics of the research community. Data from the literature on the subject will be presented on the use of coaching in supporting leaders (deans), in order to increase the effectiveness of the research process, in planning a scientific career path and in didactic work of teachers. In the text, we will show a wider context and the possibilities of using coaching in the scientific community. We will describe how coaching can support scientists in various areas of their professional work - related, inter alia, to the role of a researcher, team member, unit manager, promoter, educator, person managing their own scientific career and presenting the results of their work, as well as in achieving personal goals. Finally, the challenges related to introducing coaching in the scientific community will be mentioned.

Keywords: coaching, coaching in organization, coaching in science

Głównym celem tego rozdziału jest przybliżenie koncepcji wykorzystywania coachingu w środowisku naukowym. Rozwiązanie takie jest obecnie mało popularne (Klinkhammer, 2009), chociaż istnieją podstawy do przypuszczeń, że tego typu praca mogłaby przyczyniać się do rozwoju zawodowego i osobistego naukowców (Geber, 2010; Jones, Woods, Guillaume, 2015; Kamens, 2015). W kolejnych częściach tekstu przedstawione zostaną podstawowe informacje na temat coachingu jako formy wspierania rozwoju, dane empiryczne dotyczące efektywności tego typu interwencji, a także wybrane aspekty pracy naukowej, które mogą stanowić potencjalne obszary do pracy w ramach coachingu. 


\section{Czym jest coaching?}

Istnieje wiele sposobów, by odpowiedzieć na to pytanie. W związku z tym, że coaching rozwijał się przede wszystkim w praktyce (De Meuse, Dai, Lee, 2009), na dodatek równolegle $\mathrm{w}$ wielu podejściach i obszarach pracy (Huflejt-Łukasik, Turkowski, 2011; Pietrak, Berendt, 2019), nie zostało wypracowane spójne podejście teoretyczne, które pozwoliłoby wyjaśnić w jednym zdaniu, na czym polega ta metoda. Aby przybliżyć jej istotę z różnych perspektyw, poniżej przytoczone zostaną wybrane definicje coachingu. Następnie przeanalizowane zostaną elementy, które wyróżniają go od innych, pokrewnych form wsparcia. Na końcu zostanie natomiast przedstawiony zarys historyczny rozwoju coachingu.

Współczesne rozumienie coachingu reprezentuje między innymi definicja największej międzynarodowej organizacji zrzeszającej coachów, International Coaching Federation (ICF; https://coachingfederation.org/about, akapit 6 [dostęp 27.11.2021 r.]): „towarzyszenie klientowi w kreatywnym procesie, który pobudza do refleksji i inspiruje go do maksymalizacji swojego potencjału w sferze osobistej i zawodowej"' (tłum. własne).

W ujęciu Izby Coachingu, polskiej organizacji integrującej środowisko coachów, jest to $\mathrm{z}$ kolei "metoda wspierania rozwoju, realizowana w formie cyklu spotkań pomiędzy coachem a klientem. Coach, poprzez aktywne słuchanie, zadawanie pytań oraz stosowanie innych specyficznych narzędzi i zadań rozwojowych, towarzyszy klientowi w wyznaczaniu ważnych dla niego celów, odnajdywaniu wewnętrznych zasobów potrzebnych do ich realizacji oraz ustalaniu i wdrażaniu planów działań. Coach wspiera klienta w odkrywaniu i efektywnym wykorzystaniu swojego potencjału, w celu podnoszenia jakości życia. Coaching najczęściej jest pracą indywidualną; może także przybierać formę pracy z grupą lub zespołem" (cyt. za: Pietrak, Berendt, 2019, s. 2).

Według Johna Whitmore'a (1992, za: Wujec, 2012, s. 9) coaching to praca, która „otwiera potencjał osoby w celu zmaksymalizowania jej własnych wyników. Pomaga jej raczej uczyć się niż być nauczaną".

Definicja Roberta Diltsa (2006, s. XX) określa natomiast coaching jako „proces pomagania ludziom i zespołom w wykonywaniu zadań w możliwie jak najbardziej skuteczny sposób. Obejmuje on wydobywanie mocnych stron

1 „partnering with clients in a thought-provoking and creative process that inspires them to maximize their personal and professional potential”. 
ludzi, pomaganie w omijaniu wewnętrznych barier i ograniczeń w celu osiągnięcia osobistej doskonałości”.

Najbardziej zwięzłe określenie coachingu odnaleźć można w pracy O'Connora i Lages $(2009$, s. 2), którzy przedstawiają go jako "metodologię zmiany” (tłum. własne) - "methodology for change”.

Zamieszczony powyżej krótki przegląd definicji coachingu może dawać pewne wyobrażenie o tym, na czym polega ten rodzaj interwencji. Poszczególne sformułowania podkreślają jednak różne aspekty pracy z coachingiem, warto więc dodatkowo zaznaczyć, które elementy są kluczowe, charakterystyczne dla coachingu i pozwalają odróżnić go od innych form wspierania osób i organizacji, takich jak psychoterapia, konsulting, szkolenie, trening czy mentoring (Huflejt-Łukasik, Turkowski, 2011; Wujec, 2012). W przypadku coachingu szczególnie istotna jest koncentracja na celu klienta - jego określeniu i realizacji w toku pracy (Huflejt-Łukasik, Turkowski, 2011), a także fakt, iż to klient generuje rozwiązanie dla swoich problemów (Huflejt-Łukasik, Turkowski, 2011; O’Connor, Lages, 2009). Coaching służy uruchomieniu kreatywności klienta oraz wzmocnieniu jego zasobów tak, by osiągał rezultaty (cele), jakich pożąda.

W literaturze można spotkać się z przekonaniem, że samodzielność klienta, oparcie na jego wewnętrznych zasobach jest najbardziej charakterystyczną cechą coachingu (Wujec, 2012). W konsekwencji osoba prowadząca coaching nie musi być specjalistą w obszarze, nad którym klient chce pracować (Jones i in., 2015; O’Connor, Lages, 2009). Co więcej, jej brak wiedzy eksperckiej uznawany jest często za wartość, gdyż umożliwia coachowi skupienie na zachodzących $\mathrm{w}$ coachingu procesach $\mathrm{z}$ metapoziomu i ułatwia autentyczne słuchanie, wspieranie klienta i uruchamianie jego wewnętrznych zasobów (Geber, 2010; Jones i in., 2015; O’Connor, Lages, 2009). Coaching charakteryzuje także partnerska, symetryczna relacja między coachem a klientem (Huflejt-Łukasik, Turkowski, 2011). Coaching z założenia przeznaczony jest dla osób, które aktualnie nie wymagają psychoterapii. Ma krótkoterminową formułę (przeciętnie cała praca obejmuje kilka spotkań), opiera się na wyzwaniach dotyczących teraźniejszości i przyszłości, jak również dopuszcza elastyczność organizacji pracy - na przykład w zakresie miejsca i czasu sesji (Huflejt-Łukasik, Turkowski, 2011). Profesjonalnie przygotowany coaching opiera się na wspólnie z klientem ustalonym kontrakcie i wymaga przestrzegania przez coacha szeregu zasad etycznych, w tym obowiązku zachowania tajemnicy zawodowej (Huflejt-Łukasik, 2010a, 2010b). Dodatkowo w przebiegu coachingu ważne jest nie tylko osiągnięcie celu klienta, ale równie istotny jest 
rozwój, jaki dokonuje się przy okazji i umożliwia coachowanej osobie większą samodzielność w przyszłości (Wujec, 2012).

Zrozumienie sensu pracy z coachingiem ułatwić może również prześledzenie historii jego rozwoju, zostanie więc ona pokrótce przedstawiona w tym miejscu. Niektórzy autorzy upatrują początków coachingu w metodzie majeutycznej Sokratesa, która opierała się na wydobywaniu nieuświadamianej wiedzy poprzez pytania (O'Connor, Lages, 2009; Pietrak, Berendt, 2019). Samo słowo „coaching” pochodzi natomiast prawdopodobnie od piętnastowiecznego terminu coche, którym nazywano ekskluzywny w tamtych czasach pojazd kołowy (O'Connor, Lages, 2009; Wujec, 2012) - a zatem środek, który umożliwiał przemieszczenie klienta z miejsca, w którym się znajdował, w miejsce, do którego chciał dotrzeć (O’Connor, Lages, 2009). Z czasem wyraz zaczął stopniowo ewoluować i nabierać innych znaczeń (Pietrak, Berendt, 2019; Wujec, 2012) - około 1830 r. coachem nazywano trenera w sporcie, a 30 lat później tutora w uniwersyteckim slangu w Oksfordzie (Pietrak, Berendt, 2019; Wujec, 2012). Wkrótce określenie stosowano w odniesieniu do trenera umiejętności w różnych dziedzinach (Dilts, 2006) i w tej formie przetrwało dość długi okres. Wydarzeniem przełomowym w rozwoju coachingu okazało się wydanie książki Timothy W. Gallwey’a The inner game of tennis w 1974 r. (Wujec, 2012). Autor zawarł w niej koncepcję pracy $\mathrm{z}$ wewnętrznymi przeszkodami, która stanowiła istotną część przygotowania zawodnika do rywalizacji sportowej. Innowacyjność tego podejścia polegała na założeniu, że osiągnięcie pełni swoich możliwości wymaga pokonania osobistych, wewnętrznych ograniczeń (O’Connor, Lages, 2009). Moment ten można uznać za narodziny „coachingu przez duże C" w ujęciu Roberta Diltsa, które akcentuje różnice między trenowaniem wyłącznie określonych zachowań („coaching przez małe c”) a pracą uwzględniającą dynamikę procesów psychologicznych zachodzących podczas planowania i realizacji celów („coaching przez duże C”; Dilts, 2006; Wujec, 2012). W następstwie takiej zmiany myślenia coaching zaczął czerpać $\mathrm{z}$ dorobku innych dziedzin. Szczególny wkład w rozwój coachingu wniosły między innymi niektóre nurty psychologii. Podejście humanistyczne wzmocniło przekonanie, że to klient $\mathrm{w}$ coachingu jest ekspertem i podstawą do pracy powinny być jego indywidualne wartości i subiektywnie doświadczana rzeczywistość (O’Connor, Lages, 2009). Paradygmat ten zakłada, że w naturze człowieka leży zdolność do samodoskonalenia, a profesjonalna pomoc powinna jedynie stworzyć optymalne warunki, aby potencjał ten mógł się rozwijać (O’Connor, Lages, 2009; Rogers, 1984). Inne szkoły psychologiczne 
zaczęły natomiast dostarczać teoretycznych oraz empirycznych podstaw do konstruowania narzędzi i technik pracy coachingu (Dilts, 2006). Kolejnym ważnym źródłem inspiracji okazała się filozofia wschodnia i jej wartości oraz metody służące rozwojowi samoświadomości, zdolności do samoobserwacji, powstrzymywania się od oceny, a także podnoszenia jakości doświadczenia niezależnie od posiadanych osiągnięć. Na charakter współczesnego coachingu wpłynęły również: konstruktywizm, zakładający, że człowiek samodzielnie kształtuje swoje doświadczenie; kultura indywidualistyczna, w której cenione jest aktywne działanie jednostki; w końcu przemiany społeczno-gospodarcze, w tym przyspieszony rozwój o globalnym zasięgu, który sprawił, że dla odnalezienia się w rzeczywistości istotne stały się cechy takie jak kreatywność i zdolność do adaptacji (O’Connor, Lages, 2009). Coaching w tak rozwiniętej formie od połowy XX wieku szybko zaczął zdobywać popularność zwłaszcza w sporcie i biznesie (dziedzinach, które charakteryzuje szczególne nastawienie na rywalizację i konieczność uzyskiwania optymalnych wyników), jak również pod postacią coachingu osobistego, zorientowanego na pracę nad indywidualnymi celami klienta (bez wpływu oczekiwań sponsorów coachingu w miejscu pracy). Z pewnym opóźnieniem względem praktyki nastąpił rozwój struktur organizacyjnych wspierających pracę coachów na świecie. W 1992 r. Thomas Leonard założył pierwszą szkołę coachingu, Coach University, a w 1994 r. międzynarodową organizację zrzeszającą praktykujących coachów - International Coach Federation (ICF). W końcu przełom XX i XXI wieku przyniósł także zainteresowanie coachingiem w świecie naukowym. Rozpoczęła się praca nad badaniem efektywności metody i naukowych podstaw jej działania, aby stworzyć bazę dla pracy opartej na dowodach naukowych (O’Connor, Lages, 2009).

\section{Czym jest coaching w organizacji?}

Organizacje były jednym z tych miejsc, gdzie coaching intensywnie się rozwijał zarówno jako (1) sposób wspierania pracowników w ich zadaniach zawodowych przez liderów czy bardziej doświadczonych kolegów (czyli wykorzystanie kompetencji coachingowych w mentoringu), (2) narzędzie doradców pozwalające lepiej odpowiadać na potrzeby klientów, mocniej uwzględniać specyfikę ich pracy i w końcu jako (3) zewnętrzne wsparcie psychologiczne przy problemach, umożliwiające osobie pokonanie trudności i rozwój w roli zawodowej w ramach organizacji (por. Liljenstrand, 2003). 
Dynamicznie zmieniające się otoczenie oraz wysoka konkurencyjność na rynku wymuszają na organizacjach nieustanne zmiany oraz sięganie po skuteczne metody rozwoju (Rosha, Lace, 2016; Stankiewicz, Bortnowska, 2013). A jednym $z$ najważniejszych czynników determinujących, czy dana organizacja odniesie sukces na rynku, jest kapitał ludzki (Zelga, 2017). Aby nadążyć za konkurencją oraz podnieść jakość wykonywanej pracy, firmy coraz częściej inwestują w metody rozwoju swoich pracowników. Stąd popularność coachingu w środowisku biznesowym stale rośnie (Rosha, Lace, 2016). Organizacje korzystają z coachingu, ponieważ jest to skuteczna, szybka oraz ekonomicznie opłacalna forma wspierania pracowników, która pozwala na rozwój ich potencjału (Huflejt-Łukasik, Zawiłowski, Budkowski, 2015). Jej celem jest umożliwienie ludziom skutecznego osiągania celów zawodowych i biznesowych (Huflejt-Łukasik, Turkowski, 2011).

Coaching w organizacji zakłada relację trójstronną, w której uczestniczą pracownicy organizacji, podmiot oferujący usługę oraz podmiot reprezentujący organizację (Wujec, 2012). Należy podkreślić, że takie ujęcie coachingu uwzględnia jednocześnie potrzeby pracownika oraz organizacji, która jest płatnikiem usług. Sam coaching może przyjąć różne formy oraz być oferowany $\mathrm{w}$ różnych sytuacjach. Jedną $\mathrm{z}$ jego odmian, po którą często sięgają przedsiębiorstwa, jest coaching biznesowy (executive coaching), który jest dedykowany kadrze zarządzającej oraz kierowniczej (Zelga, 2017). Jest on „ukierunkowany na rozwój sprawności biznesowej, usprawnienie procesów zarządczych oraz działania nad celami i rezultatami biznesowymi” (Zelga, 2017, s. 34). Może m.in. dostarczać wsparcie w tworzeniu czy sprawdzaniu kierunku rozwoju dla organizacji, jej wizji, oraz w tworzeniu strategii - planowaniu i realizacji celów strategicznych. Jest pomocny przy weryfikowaniu i wprowadzaniu zmian organizacyjnych oraz dbaniu o zasoby ludzkie (por. Grant, 2014; Grant, Curtayne, Burton, 2009; Grant i in., 2017; Grover, Furnham, 2016).

Innym bardzo powszechnym jest coaching zawodowy, umożliwiający pracownikowi wprowadzanie zmiany w swoim życiu zawodowym (może być połączony z coachingiem kariery), czy rozwój w danej roli zawodowej, a także bieżące wsparcie w trudnych, wymagających sytuacjach. Najczęściej jest on oferowany menedżerom czy liderom, stanowiąc w części organizacji podstawową metodę ich rozwoju w roli zawodowej (por. Grover, Furnham, 2016; Jones i in., 2015; Liljenstrand, 2003). Ten rodzaj coachingu można opisać jako „praktyczny proces rozwoju menedżera, prowadzący do osiągnięcia wymiernie określonych osobistych celów, które wspierają rozwój organizacji. 
Ma on formę indywidualnych spotkań, bazujących na faktach czerpanych z wielu perspektyw i opartych na zaufaniu i szacunku. Organizacja, menedżer i coach pracują jako partnerzy, aby osiągnąć maksimum efektu na podstawie formalnie ustalonej umowy coachingowej" (Wujec, 2012, s. 24). Organizacje sięgają również po coaching zespołów oferowany np. członkom zespołów zarządzających czy projektowych, czyli wydzielonym formalnie lub zadaniowo zespołom (Huflejt-Łukasik, Zawiłowski, Jędrzejczyk, 2017; Zelga, 2017). Najczęstszymi tematami coachingu zespołów są: budowanie zespołów, usprawnienie efektywności ich pracy i współpracy w zespole, rozwiązywanie konfliktów, wsparcie przy wprowadzaniu zmian w organizacjach, czy spotkania strategiczne służące przejrzeniu zrealizowanych i zaplanowanie realizacji aktualnych celów zespołu. Specyficzną forma coachingu w organizacji jest też coaching na stanowisku pracy. Polega na towarzyszeniu osobie czy zespołowi w realizacji bieżących zadań zawodowych, tak by te bezpośrednie obserwacje przełożyć na informację zwrotną i pracę podczas sesji.

\section{Realizacja coachingu w organizacji}

Realizacja coachingu w organizacji jest procesem złożonym i wielopoziomowym, którego jakość oraz efekty w istotnym stopniu zależą od właściwego przygotowania przez coacha oraz firmę, dla której świadczy usługi (Huflejt-Łukasik i in., 2015; Zawiłowski, 2016). Przed przystąpieniem do realizacji zadania, coach powinien w pierwszej kolejności odbyć spotkanie z przedstawicielami organizacji, w celu analizy jej potrzeb. Jest to również czas, kiedy może potwierdzić, czy coaching jest najlepszym wyborem. Bywa bowiem, że organizacja świadoma swoich potrzeb, nie jest świadoma typu interwencji, jaki jest adekwatny w danej sytuacji. Zamawia więc usługę coachingu, kiedy bardziej wskazane jest przeprowadzenie np. szkolenia bądź konsultingu (Zawiłowski, 2016), choć póki co częściej ma miejsce odwrotna sytuacja, czyli np. próba zamawiania szkoleń, tam gdzie coaching jest adekwatną metodą. A zatem coaching jest narzędziem eksperta, którego zadaniem jest poznanie celów danej organizacji i wskaźników ich osiągnięcia, a następnie na tej podstawie dobranie najlepszych metod pracy. Kiedy coaching uznany zostanie za właściwą metodę pracy, przechodzi się do omówienia jego trybu, sposobu oceny jego efektów oraz innych istotnych kwestii, jak np. zasada poufności czy sposób raportowania informacji o postępach (Huflejt-Łukasik i in., 2015). 
Po ustaleniu wszystkich aspektów merytorycznych i formalnych z przedstawicielami organizacji (tzw. sponsorem, czyli inicjatorem projektu coachingu, przedstawicielami HR, przełożonymi) oraz zawarciu umowy z organizacją, ma miejsce zakomunikowanie informacji o coachingu osobom, dla których został on zamówiony. Jest to ważny moment, ponieważ sposób przekazania tej informacji może wpłynąć na motywację i gotowość ludzi do pracy w ramach coachingu. Po tym coach może przejść do kolejnej fazy, jaką jest spotkanie z klientem coachingu, czyli pracownikiem czy pracownikami (w przypadku coachingu zespołu). W przypadku coachingu indywidualnego pracownicy odbywają bezpłatne spotkania zapoznawcze $\mathrm{z}$ coachami, a następnie dokonują wyboru osoby, z którą chcą pracować. Po wyborze coacha podczas pierwszego spotkania $w$ ramach procesu coachingu dochodzi do zawarcia kontraktu między coachem a klientem. Kontrakt w coachingu to wypracowane między coachem a klientem ustaleń mających na celu przekazanie przez coacha zasad, według których odbywać się będzie coaching oraz dopasowanie ich do indywidualnego przebiegu coachingu w przypadku danego klienta. Ustalenia dotyczą dalszej współpracy - celów klienta, trybu coachingu, a w przypadku zasad coachingu - zwłaszcza zasady poufności. W trakcie tego spotkania sprawdza się też poziom zrozumienia celów coachingu ze strony wszystkich uczestników projektu coachingu w organizacji (pracowników, czyli klientów coachingu, podmiotu reprezentującego organizację oraz podmiotu oferującego usługę). Rolą coacha jest sprawdzenie, na ile cele indywidualne klienta są zbieżne z celami organizacji (Huflejt-Łukasik, 2010a; Huflejt-Łukasik, Turkowski, 2011; Huflejt-Łukasik i in., 2015). Najważniejszym celem kontraktu jest jednak zbudowanie odpowiedniej relacji, która umożliwi skuteczną pracę w ramach coachingu.

$\mathrm{W}$ przypadku coachingu zespołu rozwiązaniem, które najlepiej pozwala ustalić rzeczywisty, bardziej precyzyjny wspólny cel coachingu zespołu, jest zebranie wcześniej potrzeb i oczekiwań w ramach indywidualnych rozmów z każdym uczestnikiem coachingu zespołu. Na tej podstawie tworzy się też agendę, ramowy scenariusz pracy w ramach coachingu, który oczywiście może podlegać dynamicznym zmianom $\mathrm{w}$ trakcie procesu, choć cel zawsze pozostaje ten $\mathrm{sam}^{2}$.

2 Warto nadmienić, że w przypadku coachingu zespołu pracuje się z całym zespołem wraz z liderem, co jest istotną różnicą w stosunku do szkoleń. 


\section{Kiedy warto sięgnąć po coaching w organizacji?}

Określenie jasnych wytycznych, kiedy warto wdrożyć coaching w organizacji, nie jest proste, ponieważ znajduje on szerokie zastosowanie w wielu obszarach. Oprócz dostarczania możliwości systematycznego korzystania $\mathrm{z}$ coachingu przez liderów, menedżerów, zwłaszcza kiedy mają miejsce szczególnie wymagające sytuacje i zadania, sięganie po coaching dotyczy m.in. sytuacji, kiedy wykonanie zadania przez pracownika (czy zespół) wymaga od niego (nich) niestandardowego rozwiązania, czy też kiedy rozwój w danej roli zawodowej zależy od pracy nad indywidualnymi ograniczeniami. Często ta praca dotyczy takich poziomów funkcjonowania (np. emocje, przekonania, obraz siebie), które wymagają indywidualnego coachingu, bo ważna jest dyskrecja. Coaching znajdzie również zastosowanie w sytuacji, kiedy pracownik potrzebuje wsparcia w realizacji bieżących zadań oraz kiedy doświadcza trudności we współpracy z innymi osobami (Huflejt-Łukasik, Turkowski, 2011). Wykorzystuje się coaching również do poprawy wydajności, rozwijania kompetencji u pracowników, rozwoju przywództwa, czy też w kontekście zarządzania karierą (Rosha, Lace, 2016). Decyzja o wdrożeniu coachingu w organizacji może zależeć od wielu różnych czynników. Profesjonalny i kompetentny coach powinien umieć ocenić każdą sytuację indywidualnie i adekwatnie do niej doradzić organizacji odpowiedni rodzaj interwencji (Zawiłowski, 2016).

Profesjonalnie przeprowadzony coaching niesie dla pracowników oraz organizacji wiele korzyści (Rosha, Lace, 2016; Zelga, 2017). Przedsiębiorstwa oczekują od swoich pracowników stałego podnoszenia kompetencji, wysokiej motywacji oraz stosowania adekwatnych wzorców zachowań. W takich sytuacjach coaching może być metodą, która wspiera osoby w ich rozwoju, podnosi samoświadomość, zwiększa jasność odnośnie własnych celów, wzmacnia i rozwija mocne strony osoby oraz zapewnia lepsze dopasowanie do pełnionej roli w organizacji (por. Rosha, Lace, 2016). Pozwala również na lepsze dopasowanie sposobu realizacji zadań do potencjału danej osoby, podnosi satysfakcję z realizowanej pracy oraz zwiększa lojalność pracowników wobec firmy (Zelga, 2017). Coaching wpływa więc całościowo na rozwój i wzrost potencjału u ludzi, a to przekłada się na rozwój i wzrost wartości całej firmy. Należy jednak pamiętać, że w związku ze złożonością procesu coachingu w organizacji ważne jest, by dokonując wyboru coacha, rzetelnie sprawdzić jego kompetencje i doświadczenie (zob. też: Huflejt-Łukasik i in., 2015). 


\section{Coaching z perspektywy nauki: dane z badań dotyczących efektywności coachingu}

Tak jak zostało już zaznaczone wcześniej, obszar badań naukowych dotyczących coachingu rozwijał się z opóźnieniem w stosunku do praktyki (De Meuse i in., 2009). W sytuacji braku spójnych podstaw teoretycznych opracowanie naukowe na temat pracy z coachingiem okazało się wyzwaniem. Literatura na temat efektywności coachingu jest zdominowana przez dyskusje o tym, jakie efekty są kluczowe w coachingu i w jaki sposób należałoby dokonywać ich pomiaru (Grant, 2013; Jones i in., 2015). Czy powinno uwzględniać się opinię klienta na temat pracy (O’Connor, Lages, 2009)? Czy lepiej opierać się na wskaźnikach ilościowych, szacując korzyści finansowe, jakie coaching przyniósł osobie bądź organizacji (De Meuse i in., 2009)? A może zysk finansowy nie odzwierciedla wszystkich efektów pracy, jakich może dostarczyć profesjonalnie przeprowadzony coaching (Grant, 2013; O'Connor, Lages, 2009)?

Niezależnie od tego typu rozważań w literaturze zgromadzone zostały już empiryczne dane wskazujące na to, że coaching jest skuteczną metodą pracy z osobami i organizacjami (Grant, 2013; Jones i in., 2015). Najbardziej syntetyczne ujęcie tych wyników odnaleźć można w czterech metaanalizach dotyczących efektywności coachingu (Kotte, Hinn, Oellerich, Möller, 2016). Najważniejsze wnioski z tych opracowań zostaną przytoczone poniżej.

Pierwszą metaanalizę i zarazem pierwszy krok w kierunku rzetelnego opracowania danych na temat skuteczności coachingu przeprowadził zespół pod kierownictwem Kennetha P. De Meuse (De Meuse i in., 2009). Praca autorów koncentruje się na analizie efektywności coachingu zarządczego i składa się z dwóch części. Pierwsza część zawiera metaanalizę wyników sześciu badań, która wykazała, że coaching przynosił poprawę w zakresie umiejętności zarządczych i/lub poziomu wykonywania pracy o sile efektu od umiarkowanej do dużej ( $d=1,27$ przy ocenie dokonywanej przez osoby coachowane i $d=0,50$ dla ocen innych osób). Drugą część artykułu stanowi uzupełniający przegląd 10 badań retrospektywnych. W podsumowaniu tego przeglądu autorzy określili uśredniony odbiór coachingu przez klientów jako bardzo pozytywny (De Meuse i in., 2009).

Kolejna metaanaliza badająca skuteczność coachingu pojawiła się pięć lat później i obejmowała ewaluację coachingu w szerszym kontekście, mianowicie w odniesieniu do pracy coachingowej w organizacjach (Theeboom, Beersma, van Vianen, 2014). Uwzględnione zostało 18 badań. W toku analizy 
przeprowadzono procedury zgodnie ze standardami PRISMA. Okazało się, że coaching istotnie statystycznie zwiększał poziom umiejętności i wykonywanej pracy $(g=0,60)$, dobrostan pracowników $(g=0,46)$, zdolność radzenia sobie $(g=0,43)$, a ponadto pozytywnie wpływał na postawy wobec pracy $(g=0,54)$ i zorientowaną na cele samoregulację ( $g=0,74$; Theeboom i in., 2014).

Trzecia metaanaliza została przeprowadzona przez Rebeccę J. Jones i in. (2015) i dotyczyła wyników pracy z coachingiem w organizacjach. Opierała się na danych z 17 badań. Nowatorski charakter tego opracowania polegał na próbie zintegrowania wyników z teorią psychologiczną - przed obliczeniami autorzy postawili hipotezy wyprowadzone $\mathrm{z}$ teorii uczenia się i psychologii organizacji. Analiza potwierdziła ich przewidywania - coaching pozytywnie oddziaływał na umiejętności $(\delta=0,28)$ i funkcjonowanie afektywne klientów $(\delta=0,51)$, a także wyniki ich pracy $(\delta=1,24$; Jones i in., 2015).

Zespół Shirley C. Sonesh (Sonesh i in., 2015) zastosował jeszcze inne podejście. Aby pogłębić rozumienie mechanizmów, jakie odpowiadają za efekty pracy z coachingiem, badacze postawili hipotezę, że to stworzenie relacji między klientem a coachem przyczynia się do realizacji celów klienta. W literaturze relacja $\mathrm{z}$ coachem bywa wymieniana bowiem jako jeden $\mathrm{z}$ kluczowych czynników wyjaśniających skuteczność coachingu. Zebrane z 24 badań dane okazały się jednak niewystarczające do rozstrzygnięcia głównej hipotezy. Pozwoliły one natomiast potwierdzić efekty coachingu związane $\mathrm{z}$ osiąganiem celów $(g=0,22)$, zmianami zachowania $(g=0,19)$, zmianami postaw w obszarach osobistych $(g=0,08)$ i zawodowych $(g=0,19)$, satysfakcją klienta z coachingu $(g=0,40)$, poprawą relacji z innymi ludźmi $(g=0,12)$, zmianami myślenia $(g=0,22)$ i poziomem wykonywania zadań ( $g=0,37$; Sonesh i in., 2015).

\section{Nauka z perspektywy coachingu: specyfika pracy naukowców i wynikające z niej potencjalne obszary do pracy w coachingu}

Wobec rosnącej popularności coachingu w wielu dziedzinach ludzkiej działalności interesującym zjawiskiem zdaje się względna nieobecność tej metody w środowisku naukowym (Klinkhammer, 2009). Wyjaśnienie przyczyn takiego stanu rzeczy wymagałoby przeprowadzenia odrębnych badań, warto jednak zacząć dyskusję od teoretycznych rozważań. Jedna z zasadniczych kwestii wymagających rozstrzygnięcia zawiera się w pytaniu: czy i w jaki sposób coaching może pomóc naukowcom? W tym miejscu zostanie podjęta próba 
identyfikacji potencjalnych obszarów do pracy coachingowej z naukowcami, wynikających ze specyfiki środowiska naukowego.

Zawód naukowca może wiązać się $\mathrm{z}$ wykonywaniem różnych ról. Każdą $\mathrm{z}$ nich cechują inne wyzwania i każda wymaga od naukowca innego typu umiejętności.

Pełnienie roli badacza opiera się na pracy umysłowej i wymaga zdolności myślenia na wysokim poziomie. W tym kontekście coaching mógłby dostarczać naukowcom różnych narzędzi pracy pomocnych w podnoszeniu jakości procesów umysłowych, od technik rozwijających kreatywne myślenie, zmiany perspektywy, po wsparcie w rozwiązywaniu samych problemów badawczych. Sprawność myślenia nie jest jedyną pożądaną wartością w pracy naukowca-badacza; kolejnym istotnym wyzwaniem jest dążenie do jego obiektywizmu. Wsparciem dla tego dążenia mogłoby być zwiększanie świadomości naukowca w zakresie czynników wpływających na myślenie w wymiarze subiektywizmu-obiektywizmu, takich jak ograniczające przekonania czy emocje, a następnie nauka samodzielnego rozpoznawania własnych nastawień, przekonań oraz radzenia sobie z emocjami. Kolejną charakterystyczną cechą działalności badawczej naukowców jest często możliwość samodzielnej organizacji pracy - chociażby w zakresie jej miejsca i czasu. Sytuacja taka oznacza, że umiejętność optymalnej organizacji czasu i zarządzanie sobą w czasie może wpływać na produktywność naukowców i zarazem wyniki pracy naukowej. Minimalna obecność zewnętrznych zobowiązań zwiększa również rolę, jaką w pracy badacza odgrywa motywacja wewnętrzna i zdolność do inicjowania działań, nad którymi również można pracować podczas coachingu. Swoboda w planowaniu czasu pracy sprawia także, że potencjalnie istotnym tematem dla naukowca może stać się wypracowywanie balansu między aktywnością zawodową a życiem osobistym. W ramach pokrewnych zagadnień można byłoby również poszukać optymalnego sposobu na odpoczynek, a także objąć pracą coachingową całą sferę osobistą naukowca, zwracając uwagę na to, że uporządkowanie życia osobistego pozostawia więcej przestrzeni i zasobów na produktywną pracę zawodową (Geber, 2010).

Następny obszar do potencjalnej współpracy z coachem wynika z tego, że naukowiec zawsze, $\mathrm{z}$ większą lub mniejszą świadomością, prowadzi swoją karierę zawodową. Staje przed wyzwaniem prezentowania swoich wyników na konferencjach, nawiązywania kolejnych współpracy czy podejmowania strategicznych decyzji co do własnej działalności. Coaching może być w związku z tym okazją do przemyślenia możliwych rozwiązań i zaplanowaniu optymalnej ścieżki kariery (Kamens, 2015). 
Prowadzenie badań naukowych często wymaga utworzenia zespołów badawczych, co sprawia, że naukowiec musi odnaleźć się również w roli członka zespołu. Praca zespołowa wymaga specyficznych umiejętności, takich jak efektywna komunikacja, organizacja pracy grupy, prowadzenie konstruktywnej dyskusji czy przyjmowanie negatywnej informacji zwrotnej (co jest związane między innymi ze wspomnianym wcześniej dążeniem do obiektywizmu i regulacją emocji). Coach współpracujący z zespołem badawczym mógłby wspomagać rozwijanie tego typu umiejętności, a ponadto pełnić rolę facylitatora grupowego poszukiwania rozwiązania problemu badawczego.

Wielu naukowców w czasie swojej kariery staje przed wyzwaniem pełnienia funkcji kierowniczej. Sytuacja taka może wynikać z potrzeby koordynacji projektu badawczego albo wiązać się $\mathrm{z}$ pracą $\mathrm{w}$ ramach struktur uniwersyteckich. Warto zwrócić uwagę, że pełnienie na przykład funkcji rektora czy dziekana wymaga od osoby zupełnie innych umiejętności niż praca badawcza. W praktyce jednak naukowcy obejmujący stanowiska kierownicze często są pozbawieni profesjonalnego wsparcia i nieprzygotowani do zmiany roli (Bertrand, 2019). W przypadku wspomnianej funkcji dziekana skutkuje to między innymi tendencją do zarządzania opartego na unikaniu ryzyka, które znacząco ogranicza możliwości rozwoju wydziału (Bertrand, 2019). Coaching przeprowadzony $\mathrm{w}$ takim momencie mógłby pomóc $\mathrm{w}$ rozwinięciu umiejętności zarządzania, a także radzenia sobie ze stresem czy budowania relacji wewnątrz i poza wydziałem. Należy zaznaczyć, że poprawa funkcjonowania naukowca w roli dziekana nie jest jedynie kwestią indywidualnej kariery, ale realnie wpływa na możliwości rozwoju całej jednostki.

Należy dodać, iż uczelnie są specyficznymi organizacjami. Systematyczne rotowanie kadry zarządzającej (rektorzy, dziekani), która wywodzi się ze świata nauki, nie będąc najczęściej profesjonalnymi menedżerami, hierarchiczność (strukturalna i wykształcenia) instytucji oraz istniejące w niej podziały organizacyjne (administracja, naukowcy), które są źródłem konfliktów strukturalnych, unikalność, różnorodność (także procesów i procedur) oraz autonomia wewnętrznych jednostek uczelni, i w końcu podleganie MEiN i wpływ zewnętrznych regulacji, są tylko częścią opisu specyfiki uczelni. Powodują natomiast, iż codzienne zarządzanie uczelnią, kwestie organizacyjne oraz wprowadzanie zmian (które wszak są częstym doświadczeniem uczelni i jej pracowników) są szczególnie wymagające, potrzebują uwagi, wielu działań i obarczone są stresem. Coaching jako narzędzie wsparcia liderów w szczególnie trudnych sytuacjach byłby zatem bardzo pomocny. 
Kolejną funkcją wymagającą od naukowca specyficznych umiejętności jest rola promotora. W praktyce prace dyplomowe często przygotowywane są przez studentów w pośpiechu i stresie, bez świadomości, na czym polega cały proces badawczy (Ciesielka, 2014). Tymczasem gdyby promotor potrafił odpowiednio pokierować pracą studenta, mógłby pomóc mu w przygotowaniu do przyszłej pracy zawodowej, umożliwić rozwój zawodowy i uświadomić jego własne zasoby, nauczyć samodzielnej pracy, odpowiedzialności, planowania i organizacji, pomóc dostrzec sens pracy, wzbudzić motywację wewnętrzną oraz zainspirować do kolejnych przedsięwzięć (Ciesielka, 2014). Coaching również w tym przypadku mógłby wspomóc naukowca w doskonaleniu umiejętności przydatnych przy pełnieniu roli promotora, a de facto mentora. Kompetencje coachingowe są podstawą zarówno roli mentora, jak i coacha, a faktycznie role te odróżnia doświadczenie zawodowe coacha-mentora, którym, w przypadku mentoringu, może się dzielić.

Nieodłącznym elementem pracy wielu naukowców jest także działalność dydaktyczna. Dane empiryczne potwierdzają, że coaching przeznaczony dla nauczycieli pozytywnie wpływa na osiągnięcia uczniów w szkołach (Barr, 2016), można więc spodziewać się, że tego typu wsparcie pozwoliłoby również naukowcom udoskonalić swoje umiejętności dydaktyczne. Ponadto kontakt ze studentami może być także okazją do inspirujących dla naukowca dyskusji, wglądów i poszerzania własnej perspektywy o przemyślenia innych osób. W tym kontekście umiejętność prowadzenia ciekawych, aktywizujących zajęć i nawiązywania dobrych relacji ze studentami może przekładać się również na wyniki w pracy badawczej. Naukowiec to także osoba, która nieustannie sama się uczy i w ramach przygotowywania własnych badań na co dzień poznaje nowe koncepcje. Znajomość technik uczenia się mogłaby więc pozwolić na zwiększenie efektywności pracy w tym zakresie (Barr, 2016; Nieuwerburgh, Campbell, 2015; Robinson, 2015; Sepulveda, 2017).

Należy zaznaczyć również, że w szerszej perspektywie każdy naukowiec jest także częścią szerszego systemu społecznego. Globalne przemiany we współczesnym świecie wiążą się z dostępnością coraz bardziej zaawansowanych technologii. Nie zawsze jednak potrafimy wykorzystywać je w odpowiedzialny sposób (Kauffman, Bachkirova, 2008). Odpowiedzią na taką sytuację mogłoby być między innymi rozwijanie świadomości naukowców dotyczącej etycznych konsekwencji ich działań i decyzji. Praca na poziomie odkrywania znaczenia pracy czy tożsamości naukowca i osobistej misji życiowej mogłaby przełożyć się na jego funkcjonowanie we wszystkich rolach opisanych w tym podrozdziale (Dilts, 2006). 


\section{Zakończenie: czym może być coaching dla naukowców?}

W myśl zasady, że to klient jest stroną poszukującą najlepszych dla siebie rozwiązań w coachingu, hipotetyczna współpraca między naukowcami a coachami powinna rozpocząć się od rozpoznania potrzeb naukowców, a następnie dopasowania się do tych potrzeb przez osoby prowadzące coaching. Do kwestii, które należałoby uzgodnić przy planowaniu coachingu dla naukowców, należy nie tylko zakres tematów do pracy, ale i jej forma; coaching umożliwia bowiem zarówno pracę indywidualną, jak i wsparcie zespołów badawczych czy łączenie spotkań indywidualnych z tematycznymi szkoleniami rozwijającymi konkretne umiejętności w grupie. Oprócz wsłuchania się w potrzeby odbiorców przed osobami zainteresowanymi coachingiem naukowców stoją co najmniej dwa wyzwania. Po pierwsze, jeśli standardy etyczne wymagają, aby zgoda klienta na pracę była w pełni świadoma, zadaniem coachów jest rzeczowe, klarowne przedstawienie informacji na temat tego, na czym polega coaching i zwiększanie świadomości na temat jego realnych możliwości. Jest to szczególnie istotne w związku z tym, że wiedza naukowców na temat możliwości pracy z coachingiem jest $\mathrm{z}$ reguły niewielka (Klinkhammer, 2009; O’Connor, Lages, 2009). Po drugie, warto zadbać o dalszy rozwój badań empirycznych nad skutecznością i mechanizmami działania coachingu, tak aby praca coachów miała coraz bardziej rozbudowane podstawy naukowe. Być może dla wielu naukowców $\mathrm{z}$ racji wykształcenia opracowania takie będą stanowić szczególną wartość (Bertrand, 2019). Niniejszy tekst stanowi próbę postawienia kroku w kierunku podjęcia wymienionych wyzwań.

\section{BibLIOGRAFIA}

Barr, M. (2016). Coaching psychology in schools: Enhancing performance, development and wellbeing. Coaching: An International Journal of Theory, Research and Practice, 9(2), 1-3.

Bertrand, D. W. (2019). The practice of executive coaching to improve leadership capacity in academic deans at American higher education institutions. Coaching: An International Journal of Theory, Research and Practice, 12(2), 110-124. https:// doi.org/10.1080/17521882.2018.1545136

Ciesielka, M. (2014). Elementy coachingu w realizacji prac inżynierskich. EdukacjaTechnika-Informatyka, 5(1), 210-215. 
De Meuse, K. P., Dai, G., Lee, R. J. (2009). Evaluating the effectiveness of executive coaching: Beyond ROI? Coaching: An International Journal of Theory, Research and Practice, 2(2), 117-134. https://doi.org/10.1080/17521880902882413

Dilts, R. (2006). Od przewodnika do inspiratora, czyli Coaching przez duze „C”. Warszawa: Wydawnictwo PINLP.

Geber, H. (2010). Coaching for accelerated research productivity in Higher Education. International Journal of Evidence Based Coaching and Mentoring, 8(2), 64-79.

Grant, A. M. (2013). The efficacy of coaching. W: J. Passmore, D. B. Peterson, T. Freire (red.), Handbook of the psychology of coaching and mentoring (s. 15-39). Hoboken: Willey-Blackwell.

Grant, A. M. (2014). The efficacy of executive coaching in times of organizational change. Journal of Change Management, 14(2), 258-280.

Grant, A. M., Curtayne, L., Burton, G. (2009). Executive coaching enhances goal attainment, resilience and workplace well-being: A randomised controlled study. The Journal of Positive Psychology, 4(5), 396-407. https://doi.org/10.1080/17439760902992456

Grant, A. M., Studholme, I., Verma, R., Kirkwood, L., Paton, B., O’Connor, S. (2017). The impact of leadership coaching in an Australian healthcare setting. Journal of Health Organization and Management, 31(2), 237-252. https://doi.org/10.1108/JHOM-09-2016-0187

Grover, S., Furnham, A. (2016). Coaching as a developmental intervention in organisations: A systematic review of its effectiveness and the mechanisms underlying it. PLOS ONE, 11(7), e0159137. https://doi.org/10.1371/journal.pone.0159137

Huflejt-Łukasik, M. (2010a). The practical meaning of a coaching contract. W: L. D. Czarkowska (red.), Coaching as a method of developing human potential (s. 245-252). Warszawa: Wydawnictwa Akademickie i Profesjonalne.

Huflejt-Łukasik, M. (2010b). Zasady etyczne pomocy psychologicznej w psychoterapii i coachingu. W: W. Kaczyńska (red.), O etyce służb społecznych (s. 199-201). Warszawa: Instytut Profilaktyki Społecznej i Resocjalizacji Uniwersytetu Warszawskiego.

Huflejt-Łukasik, M., Turkowski, P. (2011). Funkcje coachingu w organizacji i dobór coacha. W: L. D. Czarkowska (red.), Coaching. Katalizator rozwoju organizacji (s. 124-138). Warszawa: Wydawnictwa Akademickie i Profesjonalne.

Huflejt-Łukasik, M., Zawiłowski, G., Budkowski, M. (2015). Profesjonalny coach - co powinien wiedzieć i potrafić: jak wybierać coachów do organizacji. W: L. D. Czarkowska (red.), Business coaching jako dźwignia rozwoju przedsiębiorczości (s. 67-88). Warszawa: Wydawnictwa Poltext.

Huflejt-Łukasik, M., Zawiłowski, G., Jędrzejczyk, J. (2017). Współpraca i motywacja w zespole - jak budować poprzez coaching W: L. D. Czarkowska (red.), Coaching jako klucz do motywacji wewnętrznej (s. 161-177). Warszawa: Wydawnictwo Poltext, Wydawnictwo Akademia Leona Koźmińskiego. 
Jones, R. J., Woods, S. A., Guillaume, Y. R. (2015). The effectiveness of workplace coaching: A meta-analysis of learning and performance outcomes from coaching. Journal of Occupational and Organizational Psychology, 89(2), 249-277. https:// doi.org/10.1111/joop.12119

Kamens, J. (2015). Career coaching for scientists. Nature Biotechnology, 33(6), 668-669. https://doi.org/10.1038/nbt.3259

Kauffman, C., Bachkirova, T. (2008). The evolution of coaching: An interview with Sir John Whitmore. Coaching: An International Journal of Theory, Research and Practice, 1(1), 11-15. https://doi.org/10.1080/17521880801945196

Klinkhammer, M. (2009). Angebot und Nachfrage von Coaching für Wissenschaftler/ innen. Organisationsberatung, Supervision, Coaching, 16(2), 122-133. https://doi. org/10.1007/s11613-009-0120-1

Kotte, S., Hinn, D., Oellerich, K., Möller, H. (2016). Der Stand der Coachingforschung: Kernergebnisse der vorliegenden Metaanalysen. Organisationsberatung, Supervision, Coaching, 23(1), 5-23. https://doi.org/10.1007/s11613-016-0444-6

Liljenstrand, A. M. (2003). A comparison of practises and approaches to coaching based on academic background (Niepublikowana praca doktorska). Alliant International University. San Diego.

Nieuwerburgh, C., Campbell, J. (2015). A global framework for coaching in education. CoachEd: The Teaching Leaders Coaching Journal, 1, 2-5.

O'Connor, J., Lages, A. (2009). How coaching works: The essential guide to the history and practice of effective coaching. Londyn: A\&C Black.

Pietrak, P., Berendt, B. (2019). Geneza i definicje coachingu. Warszawa: Izba Coachingu.

Robinson, C. E. (2015). Academic/success coaching: A description of an emerging field in higher education (Niepublikowana praca doktorska). Uniwersytet Południowej Karoliny. Columbia.

Rogers, C. (1984). Teoria terapii osobowości i relacji interpersonalnych rozwinięta w oparciu o podejście skoncentrowane na kliencie. Nowiny Psychologiczne, 2-3, 1-91.

Rosha, A., Lace, N. (2016). The scope of coaching in the context of organizational change. Journal of Open Innovation: Technology, Market, and Complexity, 2(2), 1-14. https://doi.org/10.1186/s40852-016-0028-x

Sepulveda, A. (2017). Coaching and mentoring in higher education: A step-by-step guide to exemplary practice. Coaching: An International Journal of Theory, Research and Practice, 10(2), 1-2. https://doi.org/10.1080/17521882.2017.1310121

Sonesh, S. C., Coultas, C. W., Lacerenza, C. N., Marlow, S. L., Benishek, L. E., Salas, E. (2015). The power of coaching: A meta-analytic investigation. Coaching: An International Journal of Theory, Research and Practice, 8(2), 73-95. https://doi.org /10.1080/17521882.2015.1071418 
Stankiewicz, J., Bortnowska, H. (2013). Kultura coachingu w organizacji; potrzeba i proces jej kształtowania. Przegląd Organizacji, 10(885), 18-24.

Theeboom, T., Beersma, B., van Vianen, A. E. (2014). Does coaching work? A meta-analysis on the effects of coaching on individual level outcomes in an organizational context. The Journal of Positive Psychology, 9(1), 1-18. https://doi.org/10.10 80/17439760.2013.837499

Wujec, B. (2012). Geneza i definicje coachingu. Coaching Review, 1(4), 4-28. Pobrane z: https://journals.kozminski.edu.pl/pub/6808 (dostęp 27.11.2021 r.).

Zawiłowski, G. (2016). Wdrażanie coachingu - wyzwania pierwszych kroków. Benefit, 11, 20-21. Pobrane z: https://www.benefitsystems.pl/fileadmin/benefitsystems/ miesiecznik_benefit/benefit_11_2016_23_10_www.pdf

Zelga, K. (2017). Coaching jako skuteczna forma rozwoju pracowników. Rynek Społeczeństwo - Kultura, 2(23), 32-37. 


\section{CZESŚĆ III. WYBRANE PROBLEMY KLINICZNE I SPOŁECZNE}



IZABELA CHOJNICKA (iD) https://orcid.org/0000-0001-8723-6873

Wydział Psychologii, Uniwersytet Warszawski

\section{Umiejętności narracyjne osób w spektrum autyzmu Narrative abilities in Autism Spectrum Disorder}

Sposób cytowania: Chojnicka, I. (2021). Umiejętności narracyjne osób w spektrum autyzmu. W: M. Huflejt-Łukasik, A. Pluta (red.), Mechanizmy psychologiczne i społeczne warunkujace formułowanie ocen oraz podejmowanie działań (s. 161-177). Warszawa: Wydawnictwo Liberi Libri. https://doi.org/10.47943/lib.9788363487553.rozdzial08

Badania były finansowane ze środków Wydziału Psychologii Uniwersytetu Warszawskiego przyznanych przez MNiSW w formie subwencji na utrzymanie i rozwój potencjału badawczego (501-D125-01-1250000 zlec*. 5011000226) oraz ze środków Narodowego Centrum Nauki (grant 2020/39/D/HS6/00809, 501-D125-66-0006634). 


\section{Streszczenie}

W rozdziale zaprezentowano krótko wczesne etapy rozwoju komunikacji społecznej w przebiegu rozwoju typowego oraz omówiono deficyty dotyczące aspektów pragmatycznych komunikacji społecznej, w szczególności kompetencji narracyjnych u osób w spektrum autyzmu. Opisano rolę dyskursu narracyjnego w rozwoju człowieka i jego wpływ na różne obszary funkcjonowania jednostki. Przedstawiono trudności doświadczane przez osoby z zaburzeniem ze spektrum autyzmu w tym obszarze. Zaprezentowano związek deficytów w zakresie opowiadania historii z głównymi teoriami z obszaru funkcjonowania poznawczego osób $\mathrm{z}$ autyzmem, w szczególności teorii umysłu, deficytów funkcji wykonawczych oraz słabej centralnej koherencji. Omówiono trzy poziomy analizy narracji - makrostrukturę, mikrostrukturę oraz język stanów wewnętrznych, opisujący emocje, myśli i percepcje bohaterów historii. Przedyskutowano także badania wskazujące na różnice płciowe w odniesieniu do kompetencji narracyjnych w autyzmie oraz wpływ dwujęzyczności.

Słowa kluczowe: spektrum autyzmu, zaburzenie ze spektrum autyzmu, ASD, język, umiejętności pragmatyczne, narracja

\section{Abstract}

This chapter briefly presents the early stages of the development of social communication in the course of typical development and discusses the deficits in the pragmatic aspects of social communication, in particular the narrative ability of people on the autism spectrum. The role of narrative discourse in human development and its impact on various areas of the functioning of an individual is described. The difficulties experienced by persons with autism spectrum disorder in this area are presented. The relationship between deficits in storytelling and the main theories in the area of cognitive functioning of people with autism, 
in particular the theory of mind, deficits in executive functions, and weak central coherence is presented. Three levels of narrative analysis were discussed - macrostructure, microstructure, and the language of internal states, which describes the emotions, thoughts, and perceptions of the characters in the story. Research discussing gender differences concerning narrative competence in autism and the impact of bilingualism are also discussed.

Keywords: autism spectrum, autism spectrum disorder, ASD, language, pragmatic skills, narration

Zaburzenie ze spektrum autyzmu (Autism Spectrum Disorder, ASD) należy do grupy zaburzeń neurorozwojowych o złożonej etiopatogenezie, których objawy związane są z rozwojem układu nerwowego i manifestują się na wczesnych etapach rozwoju. Objawy opisane w Diagnostyczno-statystycznym podręczniku zaburzeń psychicznych Amerykańskiego Towarzystwa Psychiatrycznego DSM-5 (American Psychiatric Association, 2013) obejmują trwałe deficyty w zakresie wzajemności społeczno-emocjonalnej, komunikacji niewerbalnej wykorzystywanej w czasie interakcji społecznych oraz deficyty $\mathrm{w}$ rozwoju, utrzymaniu i rozumieniu relacji społecznych. Obok trudności związanych z komunikacją społeczną i wzajemnością społeczno-emocjonalną w ASD występują ograniczone, powtarzalne i stereotypowe wzorce zachowań, zainteresowań i czynności.

Deficyty w zakresie komunikacji i interakcji społecznych obserwuje się w całym spektrum autyzmu, u osób różniących się poziomem funkcjonowania intelektualnego i językowego, a także z różnym poziomem ciężkości objawów charakterystycznych dla ASD w ciągu całego życia. Deficyty te, pomimo zróżnicowanego ich natężenia u poszczególnych osób z diagnozą ASD, wpływają na jakość codziennego funkcjonowania osób $\mathrm{z}$ autyzmem (American Psychiatric Association, 2013). 


\section{Komunikacja społeczna w przebiegu rozwoju typowego}

Werbalna komunikacja społeczna to używanie języka w kontekstach społecznych. Obejmuje interakcje społeczne, poznanie społeczne, pragmatykę i przetwarzanie języka. Komunikacja społeczna wymaga umiejętności dostosowywania stylu mowy do rozmówcy i kontekstu sytuacyjnego, przyjmowania perspektywy innych, rozumienia i odpowiedniego stosowania zasad komunikacji werbalnej i niewerbalnej oraz wykorzystywania strukturalnych aspektów języka (np. słownictwa, składni i fonologii) w celu osiągnięcia tych celów.

W przypadku dzieci rozwijających się typowo umiejętności komunikacji społecznej rozwijają się od urodzenia. Obejmują zarówno komunikaty niewerbalne, jak i werbalne służące nawiązywaniu relacji najpierw $z$ bliskimi opiekunami, a później także z innymi osobami. Już noworodki poprzez nawiązywanie kontaktu wzrokowego, wokalizacji i ruchów ciała wysyłają rodzicom komunikaty społeczne (Piszczek, 2013). Pod koniec 1. roku życia większość dzieci nie wypowiada jeszcze słów, ale jest w stanie koordynować pole uwagi między ludźmi i przedmiotami, angażować się w wymianę społeczną i intencjonalnie komunikować się z opiekunami za pomocą konwencjonalnych gestów i niosących znaczenie wokalizacji (Bates, O’Connell, Shore, 1987).

Jednym $\mathrm{z}$ istotnych elementów rozwoju mowy i komunikacji społecznej są umiejętności związane $\mathrm{z}$ tworzeniem wspólnego pola uwagi. Rozwój umiejętności dzielenia się uwagą zaczyna się od narodzin. Niemowlę uczy się dzielić uwagą z opiekunem $\mathrm{w}$ interakcjach diadycznych, w czasie których opiekun monitoruje to, na co patrzy dziecko. W ostatnim kwartale 1. roku życia dziecko aktywnie obserwuje innych i uczy się przenosić wzrok między ludźmi i przedmiotami, upewniając się, czy opiekun zwraca uwagę na to, co wzbudziło zainteresowanie dziecka (social referencing). Przed upływem 15. miesiąca życia dziecko potrafi nawiązywać wspólną uwagę z innymi osobami (Wetherby, 2006).

W początkowych etapach rozwoju dziecko uczy się także dzielenia się odczuwanymi emocjami, wykorzystując posiadane umiejętności komunikacyjne, takie jak np. werbalne i niewerbalne okazywanie przyjemności i kierowanie wzroku na opiekuna w celu podzielenia się tym doświadczeniem, bądź kierowanie przez dziecko do opiekuna sygnałów dyskomfortu lub niepokoju w celu uzyskania pomocy czy pocieszenia. Z kolei umiejętność dzielenia się intencjami odnosi się do zdolności sygnalizowania lub ukierunkowywania zachowania innych ludzi, aby osiągnąć określony cel. W ostatnim kwartale 1. roku życia 
dziecko zaczyna używać wokalizacji, gestów i innych zachowań, aby komunikować się z określoną intencją (Wetherby, 2006).

Wczesne intencjonalne gesty i wokalizacje stanowią komunikację przedsymboliczną i podstawę do pojawienia się pierwszych słów i znaków, umożliwiając dziecku przejście do komunikacji symbolicznej (gdy jedna rzecz oznacza lub reprezentuje coś innego). W 2. roku życia dzieci rozwijają zdolność komunikowania się w sposób symboliczny - rozwijają się umiejętności naśladowania nowych zachowań, zabawy na niby oraz rozumienia i posługiwania się słowami (Wetherby, 2006).

Zarówno umiejętność nawiązywania wspólnej uwagi, jak i używania symboli w komunikacji sprawiają, że dziecko staje się aktywnym partnerem we wzajemnej komunikacji społecznej z innymi osobami. Umiejętności te stanowią fundament potrzebny do rozwoju umiejętności prowadzenia rozmowy, uwzględniania wiedzy i perspektywy partnera oraz uczestniczenia we wzajemnej wymianie społecznej dostosowanej do kontekstu sytuacyjnego i partnera interakcji (Wetherby, 2006).

\section{Komunikacja społeczna w ASD}

Zaburzenie ze spektrum autyzmu charakteryzuje duża różnorodność w zakresie zdolności językowych, od braku mowy do swobodnego posługiwania się mową (World Health Organization, 2018). Wśród kryteriów diagnostycznych ASD wymienianych w klasyfikacji DSM-5 znajdują się trudności z prowadzeniem rozmowy, trudności z inicjowaniem i podtrzymywaniem interakcji społecznych, ograniczone okazywanie zainteresowania uczuciami i doświadczeniami innych ludzi oraz ograniczone dzielenie się własnymi emocjami i zainteresowaniami z innymi. Charakterystyczne są także deficyty w zakresie komunikacji niewerbalnej, a wśród nich trudności z prawidłowym wykorzystywaniem kontaktu wzrokowego i gestykulacji w czasie interakcji społecznych, trudności z prawidłowym wykorzystaniem ekspresji mimicznej w celach społecznych i jej rozpoznawaniem u innych, jak również ograniczony zakres wyrazów twarzy (American Psychiatric Association, 2013). Charakterystyczne dla spektrum autyzmu są deficyty w obszarze tworzenia pola wspólnej uwagi. Dzieci z ASD mają trudności z inicjowaniem wspólnej uwagi i utrzymywaniem uwagi drugiej osoby, dzieleniem się emocjami czy obiektami zainteresowania. Mogą mieć też trudności z reagowaniem na inicjowanie wspólnej uwagi przez 
inną osobę. Komunikacja dzieci z ASD rzadziej niż u typowo rozwijających się rówieśników ukierunkowana jest na cele społeczne czy społeczno-emocjonalne. Zamiast tego służy głównie regulowaniu zachowania innych osób w celu proszenia o coś czy protestowania przeciw czemuś (Wetherby, 2006). Dzieci z autyzmem mają trudności z przyciąganiem i ukierunkowaniem uwagi drugiej osoby w celu zwrócenia na coś uwagi, skomentowania czegoś, podzielenia się zainteresowaniem (Wetherby, Prizant, Hutchinson, 1998). Biorąc pod uwagę, jak wcześnie w rozwoju typowym pojawiają się umiejętności związane ze wspólną uwagą (oraz umiejętności poprzedzające nawiązywanie wspólnej uwagi, takie jak nawiązywanie kontaktu wzrokowego, przenoszenie spojrzenia, wskazywanie), deficyty w tym obszarze są charakterystyczne dla ASD, a jednocześnie nieobecne u dzieci z rozwojowym zaburzeniem języka czy globalnym opóźnieniem rozwoju (Wetherby i in., 2004).

Na trudności w zakresie komunikacji społecznej u osób z ASD składają się także inne deficyty. Dzieci z ASD mają trudności z rozumieniem i używaniem symboli w komunikacji, tj. języka, gestów, naśladowania i zabawy. $\mathrm{W}$ spektrum autyzmu znajdują się osoby $\mathrm{z}$ różnym poziomem rozumienia i produkcji mowy. W przeciwieństwie do dzieci z zaburzeniami mowy i języka bądź niedosłuchem czy głuchotą, dzieci z ASD nie kompensują trudności w zakresie komunikacji werbalnej komunikatami niewerbalnymi (American Psychiatric Association, 2013). Gestykulacja osób z ASD jest uboższa zarówno pod względem ilościowym, jak i jakościowym - różnorodności stosowanych gestów. Deficyty występują także w zakresie ekspresji mimicznej zarówno pod względem jakościowej różnorodności wyrazów twarzy, wykorzystywania ekspresji twarzy do komunikacji, ukierunkowywania jej w stronę partnera interakcji, jak i adekwatności wyrazu twarzy do kontekstu sytuacyjnego (Lord i in., 2012).

Umiejętności pragmatyczne osób z ASD. Pragmatyka językowa to wykorzystywanie komunikacji w sytuacjach społecznych w codziennych interakcjach z innymi ludźmi. Obejmuje ona to, co mówimy, jak to mówimy, naszą komunikację niewerbalną oraz to, jak adekwatne są nasze interakcje i komunikaty w danej sytuacji (Lam, 2014). Umiejętności pragmatyczne (tabela 1) są niezbędne do komunikowania naszych myśli, pomysłów i uczuć. Pragmatyczne wykorzystanie języka obejmuje używanie języka w różnych celach, takich jak na przykład witanie się, informowanie, oznajmianie lub proszenie. Obejmuje również dostosowanie używanego języka do słuchacza lub sytuacji (np. inne formułowanie wypowiedzi w kierunku nauczyciela i inne w kierunku małego dziecka; lub 
rozmowa o rodzinie $\mathrm{z}$ innym członkiem tej rodziny w porównaniu do rozmowy o rodzinie z nieznajomym). Umiejętności pragmatyczne dotyczą także umiejętności prowadzenia rozmowy z drugą osobą - naprzemienność w rozmowie i czekanie na swoją kolej, wprowadzanie nowych tematów, pozostawanie przy danym temacie i kontynuowanie go oraz ponowne formułowanie myśli, gdy nadawca jest źle zrozumiany. Ponadto umiejętności pragmatyczne obejmują także rozpoznawanie, używanie i rozumienie komunikatów niewerbalnych.

Pomimo heterogeniczności w sferze umiejętności językowych i komunikacyjnych dzieci z ASD, deficyty w obszarze umiejętności pragmatycznych występują w całym spektrum autyzmu u osób w różnym wieku (Tager-Flusberg, Joseph, Folstein, 2001). Obecność znaczących i utrzymujących się trudności w obszarze pragmatyki mowy w dzieciństwie wiąże się z dalekosiężnymi, niekorzystnymi następstwami, takimi jak trudności behawioralne w okresie dojrzewania, problemy $\mathrm{w}$ relacjach $\mathrm{z}$ rówieśnikami, utrudnione znalezienie i utrzymanie zatrudnienia czy zaburzenia zdrowia psychicznego (Howlin, 2000; Mayes, Calhoun, Murray, Ahuja, Smith, 2011; St Clair, Pickles, Durkin, Conti-Ramsden, 2011). Mimo powszechności występowania tego rodzaju deficytów w ASD, nadal brakuje badań nad skutecznością interwencji terapeutycznych obejmujących umiejętności pragmatyczne (Adams i in., 2020; Gerber, Brice, Capone, Fujiki, Timler, 2012).

Tabela 1

Przykłady pragmatycznych umiejętności językowych

\begin{tabular}{ll}
\hline \multicolumn{1}{c}{ Werbalne } & \multicolumn{1}{c}{ Niewerbalne } \\
\hline Intonacja głosu odpowiednio zmienna i dostosowana & Mowa ciała \\
do komunikatu i kontekstu & $\begin{array}{l}\text { Odległość ciała oraz zachowanie } \\
\text { i rozpoznawanie przestrzeni osobistej }\end{array}$ \\
Zadawanie pytań & $\begin{array}{l}\text { Gestykulacja } \\
\text { Ekspresja twarzy }\end{array}$ \\
Odpowiadanie i udzielanie informacji & Kontakt wzrokowy \\
Proszenie o pomoc i stosowne oferowanie pomocy & \\
Naprzemienność w rozmowie & \\
Wprowadzanie tematu rozmowy i podtrzymywanie rozmowy & \\
Adekwatne komentarze w czasie konwersacji & \\
Unikanie powtórzeń lub nieistotnych informacji & \\
Dostosowywanie języka do sytuacji lub osoby & \\
Używanie humoru & \\
Stosowanie odpowiednich strategii przyciągania uwagi & \\
Opowiadanie historii wymyślonych i prawdziwych & \\
Wzajemność społeczna (np. inicjowanie i reagowanie na inicjowanie \\
interakcji)
\end{tabular}


Umiejętności narracyjne osób z ASD. Deficyty w obszarze pragmatyki mowy i języka wśród osób w spektrum autyzmu obejmują trudności narracyjne (tj. opowiadanie historii; Baixauli, Colomer, Roselló, Miranda, 2016). Bruner (1991) opisuje narrację jako zdolność myślenia, komunikowania się i dzielenia się doświadczeniami jako sposób na ich dostosowanie i rekonstrukcję w celu lepszego ich zrozumienia. Dyskurs narracyjny to złożone zadanie poznawcze polegające na integracji informacji, zapamiętaniu szczegółów historii i wykorzystaniu zebranej wiedzy o świecie do stworzenia spójnej narracji opisującej serię działań i wydarzeń, które rozwijają się w czasie. Umiejętności narracyjne to umiejętności ubierania naszych myśli i doświadczeń w słowa oraz przekazywania wydarzeń za pomocą języka w sytuacjach komunikacyjnych. Rozwój umiejętności narracyjnych rozpoczyna się we wczesnym okresie życia i jest powiązany z rozwojem poznawczym, społecznym i językowym (Leinonen, Letts, Smith, 2000). Zdolności opowiadania historii mają wpływ na wiele aspektów rozwoju dziecka, takich jak planowanie, organizowanie i porządkowanie myśli, działania oraz rozwijanie poczucia własnej tożsamości.

Funkcjonowanie poznawcze osób z ASD a umiejętności narracyjne. Dotychczasowe badania poświęcone umiejętnościom narracyjnym w ASD dotyczyły różnic między opowiadaniami produkowanymi przez osoby w spektrum autyzmu i osoby z typowym rozwojem (TD). Trudności w zakresie opowiadania historii w autyzmie wydają się występować w językach o różnych typologiach (np. Engberg-Pedersen, Christensen, 2016; Mäkinen, Loukusa, Leinonen, Moilanen, Ebeling, Kunnari, 2014; Sah, Torng, 2015). Wielu autorów (np. Persiteri, Baldimtsi, Andreou, Tsimpli, 2020) postuluje, że obserwowane trudności w zakresie kompetencji narracyjnych u osób z ASD nie wynikają wyłącznie $\mathrm{z}$ deficytów językowych, ale również $\mathrm{z}$ nietypowego rozwoju poznawczego. Jedną $\mathrm{z}$ teorii psychologicznych istotnych $\mathrm{w}$ odniesieniu do poznania społecznego jest teoria umysłu (theory of mind, ToM), czyli zdolność rozumienia własnych i cudzych stanów emocjonalnych, rozumienie, że inni mogą mieć wiedzę, pragnienia i emocje różne od własnych, a także umiejętność spojrzenia z cudzej perspektywy i odpowiedniego zmodyfikowania użycia języka (Kimhi, 2014). Teoria umysłu i pragmatyczny wymiar języka są ze sobą ściśle powiązane i wpływają na interakcje społeczne (Rosello, Berenguer, Baixauli, García, Miranda, 2020). Kluczowych pojęć opisujących pragmatykę języka, takich jak pośrednie akty mowy, wyrażenia deiktyczne, przesłanki i domysły, czy ironia, nie da się wyjaśnić bez odwołania do ToM. Tager-Flusberg 
i Sullivan (1995), a później Capps, Losh i Thurber (2000), wykazali związek między teorią umysłu a umiejętnościami narracyjnymi u dzieci $z$ autyzmem. Dzieci z ASD miały problemy z identyfikacją stanów psychicznych, poznawczych i motywacji u bohaterów opowieści oraz z dostosowaniem narracji do odbiorcy. Gdy zadawano dzieciom pytania dotyczące zrozumienia historii, w przypadku dzieci z ASD uzyskiwano mniej trafne odpowiedzi w odniesieniu do identyfikowania emocji oraz zależności typu przyczyna-skutek.

Drugi obszar badań dotyczących charakterystyki funkcjonowania poznawczego osób z ASD dotyczy funkcji wykonawczych obejmujących procesy regulujące zachowanie i myślenie. Do funkcji wykonawczych zaliczana jest pamięć robocza, hamowanie poznawcze i przerzutność uwagi, ale także bardziej złożone procesy jak organizacja, monitorowanie działania, planowanie czynności czy rozwiązywanie problemów (Demetriou i in., 2018). Umiejętność organizowania myśli i wypowiedzi oraz koncentracji uwagi są niewątpliwie niezbędne do przedstawienia czasowych i przyczynowych zależności sekwencji wydarzeń w opowiadanej historii. Procesy uwagowe i pamięć robocza to dwa obszary funkcjonowania wykonawczego, w których identyfikowano deficyty u osób w spektrum autyzmu: osoby z ASD mają tendencję do koncentrowania się na szczegółach zamiast na analizie całościowej i jednoczesnego pominięcia znaczenia kontekstu (Koldewyn i in., 2013). Źródło tego rodzaju trudności w autyzmie wyjaśniane było teorią słabej centralnej koherencji oraz selektywnymi deficytami funkcji wykonawczych obejmujących odrębny proces wykonawczy odgórnie (top-down) regulujący zachowanie, myślenie i emocje. Skupianie się na szczegółach i izolowanych właściwościach, bez integracji tych informacji w większą całość, może mieć bezpośredni wpływ na brak spójnej, ogólnej struktury narracji i uwzględnienia kontekstu w tworzeniu znaczeń i interpretacji. Choć deficyty w zakresie ToM, funkcji wykonawczych lub słabej centralnej koherencji znajdują szerokie potwierdzenie w wielu badaniach, żadna z nich nie wyjaśnia w pełni jakościowych nieprawidłowości w sferach społecznej i komunikacyjnej charakterystycznych dla spektrum autyzmu (Baixauli i in., 2016).

Makro-i mikrostruktura narracji oraz język stanów wewnętrznych. Badania poświęcone kompetencjom opowiadania historii koncentrują się przede wszystkim na trzech poziomach analizy narracyjnej: makrostrukturze, mikrostrukturze oraz języku stanów wewnętrznych (Internal State Language, ISL). Makrostruktura obejmuje elementy fabuły historii, zawartość treściową opowiadania oraz jego hierarchiczną organizację. Narracje osób z ASD są mniej powiązane przyczy- 
nowo i mniej spójne niż te produkowane przez osoby $\mathrm{z}$ rozwojem typowym. Inne analizowane właściwości makrostruktury w narracjach dzieci z ASD obejmują podawanie istotnych i nieistotnych informacji, odwoływanie się do bohaterów opowieści w sposób przystępny i zrozumiały, a także spójność opowiadania (np. Diehl, Bennetto, Young, 2006). Dzieci z ASD w swoich narracjach mają tendencję do pomijania istotnych informacji oraz koncentrowania się na tych nierelewantnych, a także używania nieadekwatnych słów i zdań (Schoen-Simmons, Paul, Volkmar, 2014).

Z kolei mikrostruktura obejmuje wewnętrzne struktury językowe stosowane do konstrukcji narracji: słownictwo, różnorodność leksykalną (liczbę różnych słów) oraz gramatykę i morfoskładnię. Osoby z ASD tworzą narrację z mniejszą liczbą słów i zdań oraz mniejszą różnorodnością leksykalną niż dzieci i młodzież z TD (Capps i in., 2000; Tager-Flusberg, 1995). W odniesieniu do złożoności syntaktycznej narracji w ASD badania przyniosły sprzeczne wyniki: niektóre prace wskazywały na różnice w trajektorii morfosyntaktycznej między osobami z ASD a ich rówieśnikami rozwijającymi się typowo (Capps i in., 2000; Norbury, Bishop, 2003); inne nie wykazywały takich różnic (Diehl i in., 2006). Peristeri, Andreou i Tsimpli (2017) wykazali znaczącą korelację między umiejętnościami werbalnymi a złożonością składniową narracji dzieci z ASD w normie intelektualnej, co sugeruje, że w analizie umiejętności narracyjnych dzieci w spektrum autyzmu należy brać pod uwagę werbalny iloraz inteligencji.

Inną cechą narracji badaną w autyzmie jest język stanów wewnętrznych, czyli słownictwo używane do opisu percepcji, emocji i myśli bohaterów historii. W większości dotychczasowe badania ograniczały się do analizy czasowników i przymiotników odnoszących się do stanów emocjonalnych (np. „śmiać się”, „szczęśliwy”) i poznawczych (np. „wiedzieć”, „zagubiony”) postaci. Badania wykazały związek między obecnością słownictwa ISL w narracjach a teorią umysłu (Capps i in., 2000). Wyniki metaanalizy Baixauli i in. (2016) wskazują, że osoby z ASD używają mniej terminów ISL niż osoby z rozwojem typowym, przy czym IQ pełni rolę zmiennej moderującej: osoby z wysokim IQ mają większe trudności w zakresie werbalnego opisu stanów wewnętrznych bohaterów historii w porównaniu z ich rozwijającymi się typowo rówieśnikami.

Umiejętności narracyjne a płeć. Większość badań poświęconych umiejętnościom narracyjnym w ASD przeprowadzana była na grupach z przewagą chłopców i mężczyzn, która jest typowa w tym zaburzeniu (Maenner i in., 2020). W niedawno opublikowanej pracy Boorse i in. (2019) mierzyli częstotliwość wystę- 
powania dwóch rodzajów słów w historiach opowiadanych przez dziewczynki i chłopców w spektrum autyzmu: rzeczowników (części mowy wskazujące na opowiadanie zorientowane na obiekt) i języka procesów poznawczych (słowa takie jak „myśleć”, „wiedzieć”, wskazujących na mentalizację lub uwagę skierowaną na stany wewnętrzne bohaterów). Dzieci w spektrum autyzmu obojga płci używały więcej rzeczowników niż typowo rozwijający się rówieśnicy, co wskazuje na narrację skoncentrowaną na przedmiotach. Co ciekawe, różnice w stosowaniu rzeczowników występują w mowie mężczyzn i kobiet o typowym rozwoju: mowa mężczyzn zawiera więcej rzeczowników niż mowa kobiet (Pennebaker, 2011). Zatem w tym aspekcie narracja dziewcząt z ASD zbliżona jest do narracji charakterystycznej dla płci męskiej.

W badaniach Boorse i in. (2019) w grupie dzieci z rozwojem typowym nie zidentyfikowano zależnych od płci różnic w używaniu słownictwa związanego z procesami poznawczymi. Natomiast dziewczynki w spektrum autyzmu używały więcej tego rodzaju słów niż chłopcy w spektrum (przy porównywalnym nasileniu objawów autyzmu). Autorzy opisali „mieszany profil narracyjny” u dziewcząt z ASD, nakładający się na profil narracyjny chłopców z ASD i rówieśników z rozwojem typowym. Dotychczasowe badania wskazujące na to, że dzieci $\mathrm{z}$ autyzmem rzadziej używają słów związanych z procesami poznawczymi, mogą być prawdziwe tylko w odniesieniu do chłopców z ASD, podczas gdy język zorientowany na przedmioty może być markerem językowym autyzmu neutralnym pod względem płci.

Z kolei Goddard, Dritschel i Howlin (2014) badali pamięć autobiograficzną u 24 dzieci z ASD i 24 dzieci typowo się rozwijających obojga płci, dobranych pod względem wieku, IQ, płci i poziomu rozumienia mowy. Wśród badanych deficyt w przypominaniu sobie informacji w grupie ASD był bardziej charakterystyczny dla chłopców. Wspomnienia dziewcząt, zarówno w grupie TD, jak i ASD, zawierały więcej szczegółów i informacji dotyczących stanów emocjonalnych niż wspomnienia chłopców. Dziewczęta w obu grupach uzyskały też lepsze wyniki w zakresie fluencji słownej w porównaniu $\mathrm{z}$ chłopcami.

$\mathrm{W}$ artykule poświęconym językowi stanów wewnętrznych opisano $\mathrm{z}$ kolei częstsze użycie słownictwa ISL przez dziewczęta, zarówno z ASD, jak i rozwojem typowym (Kauschke, van der Beek, Kamp-Becker, 2016), przy czym dziewczęta z ASD używały mniej słów odnoszących się do stanów wewnętrznych niż ich typowo rozwijające się rówieśniczki, ale więcej niż chłopcy w spektrum autyzmu.

Omówione badania wskazują na istotną rolę płci w badaniu kompetencji narracyjnych oraz występowania profilu narracyjnego $u$ dziewcząt z ASD, 
lokującego się między profilem chłopców w spektrum autyzmu a typowo rozwijających się rówieśników. Wskazuje to na potrzebę rozwijania metod przesiewowych, diagnostycznych i badawczych uwzględniających różnice płciowe w ASD, najlepiej z wykorzystaniem obiektywnych wskaźników. Przykładem tego rodzaju metody jest intensywnie rozwijane i badane przetwarzanie języka naturalnego czy techniki uczenia maszynowego (Chojnicka, Wawer, 2020).

Umiejętności narracyjne a dwujęzyczność. Zaprezentowane powyżej wyniki badań kompetencji narracyjnych w ASD dotyczą dzieci monolingwalnych. Pamiętając, jak umiejętności te zależą od funkcjonowania poznawczego, ciekawym jest pytanie, jak dwujęzyczność wpływa na umiejętności narracyjne w autyzmie. Peristeri i in. (2020) zbadali 80 chłopców w wieku 7-12 lat, w tym: 20 monolingwalnych (mówiących po grecku) z ASD, 20 dwujęzycznych (różne języki) z ASD, a także 20 mono- (język grecki) i 20 bilingwalnych (różne języki) $z$ rozwojem typowym, dopasowanych pod względem wieku chronologicznego. W przypadku zadania narracyjnego dzieci dwujęzyczne z ASD osiągały wyższe wyniki niż dzieci jednojęzyczne z ASD w zakresie złożoności struktury opowieści i stosowania klauzul przysłówkowych, jak również używały mniej niejednoznacznych form referencyjnych niż ich jednojęzyczni rówieśnicy z ASD. $\mathrm{W}$ zadaniu badającym funkcje wykonawcze związane $\mathrm{z}$ uwagą wzrokową (global-local visual attention task) dwujęzyczne dzieci z ASD były szybsze i dokładniejsze niż dzieci jednojęzyczne z ASD. Dzieci jednojęzyczne z ASD były bardziej podatne na dystraktory $\mathrm{z}$ lokalnie prezentowanych informacji niż pozostałe grupy eksperymentalne. Wyższą dokładność i szybkość odpowiedzi zaobserwowano również $\mathrm{w}$ przypadku dwujęzycznych dzieci z ASD w zadaniu dotyczącym pamięci roboczej (2-back working memory task). Co więcej, dwujęzyczne dzieci z ASD korzystały z szerszego zakresu funkcji wykonawczych w czasie opowiadania historii niż ich jednojęzyczni rówieśnicy. Opisane wyżej badania wskazują, że dwujęzyczne dzieci z ASD osiągają lepsze wyniki niż ich jednojęzyczni rówieśnicy $z$ autyzmem zarówno pod względem mikrostruktury, jak i makrostruktury tworzonej narracji, a także funkcji wykonawczych, takich jak uwaga wzrokowa i pamięć robocza. 


\section{Podsumowanie}

Dyskurs narracyjny jest wszechobecną formą komunikacji wykorzystywaną do poznawczego reprezentowania rzeczywistości i wydarzeń, a także dzielenia się jej doświadczaniem, schematem poznawczym, w którym dostosowujemy i odtwarzamy nasze doświadczenia, aby lepiej je zrozumieć. Narracja zwykle opisuje szereg działań i wydarzeń następujących po sobie zgodnie z zasadami przyczynowości i zmieniających się w czasie. Umiejętności narracyjne odgrywają znaczącą rolę w różnych obszarach rozwojowych, mają m.in. wpływ na poziom osiągnięć szkolnych i umiejętności czytania ze zrozumieniem. Stanowią jeden z głównych sposobów udostępniania swoich doświadczeń innym ludziom, w tym już na wczesnych etapach rozwoju, wspierając rozwój relacji społecznych i przywiązania. Służą porządkowaniu wspomnień i przyswajaniu nowych doświadczeń do poczucia self.

Dotychczasowe badania wykazały szereg trudności w zakresie umiejętności prowadzenia narracji przez osoby z zaburzeniem ze spektrum autyzmu. Osoby z ASD doświadczają trudności z przekazywaniem istoty opowiadanej historii oraz wskazówek interpretacyjnych. Opowieściom osób z ASD brakuje spójności i związków przyczynowych. $Z$ kolei obecne są nieodpowiednie i nieistotne dla opowiadanej historii elementy. Narracje osób z zaburzeniem ze spektrum autyzmu charakteryzują się również mniejszą liczbą słów i zdań oraz mniejszą różnorodnością leksykalną. W badaniach poświęconych narracji osób z ASD analizom poddaje się także słownictwo służące do opisu emocji, percepcji i stanów poznawczych/mentalnych bohaterów historii, tzw. język stanów wewnętrznych (ISL). Badania wykazały, że osoby z ASD używają mniej słownictwa ISL w swoich opowiadaniach niż ich rówieśnicy rozwijający się typowo. Prowadzone dotychczas badania kompetencji narracyjnych dotyczyły w większości jednojęzycznych chłopców. Prace uwzględniające dziewczęta z ASD wskazują na różnice w profilach narracyjnych w ASD zależne od płci oraz jedno-/dwujęzyczności.

Badania poświęcone analizie umiejętności narracyjnych osób z zaburzeniem ze spektrum autyzmu mogą przyczynić się do endofenotypowej charakterystyki tego zaburzenia i ustalenia celów interwencji terapeutycznych w tym obszarze. Opublikowane w ostatnim czasie prace poświęcone wykorzystaniu narzędzi inżynierii lingwistycznej i sztucznej inteligencji $w$ analizie narracji osób z ASD wskazują na potencjał wykorzystania ich także w przyszłości w badaniach przesiewowych i diagnostycznych. 


\section{Biblografia}

Adams, C., Gaile, J., Roddam, H., Baxendale, J., Clitheroe, L., Emsley, R. (2020). Evaluation of a manualised speech and language therapy programme for children with social communication disorder: The SCIP feasibility study. Pilot and Feasibility Studies, 6(1), 137. https://doi.org/10.1186/s40814-020-00658-2

American Psychiatric Association. (2013). Diagnostic and statistical manual of mental disorders. Waszyngton: Publisher.

Baixauli, I., Colomer, C., Roselló, B., Miranda, A. (2016). Narratives of children with high-functioning autism spectrum disorder: A meta-analysis. Research in Developmental Disabilities, 59, 234-254. https://doi.org/10.1016/j.ridd.2016.09.007

Bates, E., O'Connell, B., Shore, C. (1987). Language and communication in infancy. W: J. Osofsky (red.), Handbook of infant development (s. 149-203). Nowy Jork: Wiley.

Boorse, J., Cola, M., Plate, S., Yankowitz, L., Pandey, J., Schultz, R. T., Parish-Morris, J. (2019). Linguistic markers of autism in girls: evidence of a „blended phenotype” during storytelling. Molecular Autism, 10, 14. https://doi.org/10.1186/s13229-0190268-2

Bruner, J. (1991). The narrative construction of reality. Critical Inquiry, 18(1), 1-21. https://doi.org/10.1086/448619

Capps, L., Losh, M., Thurber, C. (2000). „The frog ate the bug and made his mouth sad": Narrative competence in children with autism. Journal of Abnormal Child Psychology, 28(2), 193-204. https://doi.org/10.1023/a:1005126915631

Chojnicka, I., Wawer, A. (2020). Social language in autism spectrum disorder: A computational analysis of sentiment and linguistic abstraction. PLOS ONE, 15(3), e0229985. https://doi.org/10.1371/journal.pone.0229985

Demetriou, E. A., Lampit, A., Quintana, D. S., Naismith, S. L., Song, Y., Pye, J. E., ..., Guastella, A. J. (2018). Autism spectrum disorders: A meta-analysis of executive function. Molecular Psychiatry, 23(5), 1198-1204. https://doi.org/10.1038/mp.2017.75

Diehl, J. J., Bennetto, L., Young, E. C. (2006). Story recall and narrative coherence of high-functioning children with autism spectrum disorders. Journal of Abnormal Child Psychology, 34(1), 83-98. https://doi.org/10.1007/s10802-005-9003-x

Engberg-Pedersen, E., Christensen, R. V. (2016). Mental states and activities in Danish narratives: children with autism and children with language impairment. Journal of Child Language, 44(5), 1192-1217. https://doi.org/10.1017/s0305000916000507

Gerber, S., Brice, A., Capone, N., Fujiki, M., Timler, G. (2012). Language use in social interactions of school-age children with language impairments: An evidence-based systematic review of treatment. Language, Speech, and Hearing Services in Schools, 43(2), 235-249. https://doi.org/10.1044/0161-1461(2011/10-0047) 
Goddard, L., Dritschel, B., Howlin, P. (2014). A preliminary study of gender differences in autobiographical memory in children with an autism spectrum disorder. Journal of Autism and Developmental Disorders, 44(9), 2087-2095. https://doi. org/10.1007/s10803-014-2109-7

Howlin, P. (2000). Outcome in adult life for more able individuals with autism or Asperger syndrome. Autism, 4(1), 63-83. https://doi.org/10.1177/1362361300004001005

Kanner, L. (1943). Autistic disturbances of affective contact. Nervous Child, 2, 217-250.

Kauschke, C., van der Beek, B., Kamp-Becker, I. (2016). Narratives of girls and boys with autism spectrum disorders: Gender differences in narrative competence and Internal State Language. Journal of Autism and Developmental Disorders, 46(3), 840-852. https://doi.org/10.1007/s10803-015-2620-5

Kimhi, Y. (2014). Theory of mind abilities and deficits in autism spectrum disorders. Topics in Language Disorders, 34(4), 329-343. https://doi.org/10.1097/ tld.0000000000000033

Koldewyn, K., Jiang, Y.V., Weigelt, S., Kanwisher, N. (2013). Global/Local processing in autism: Not a disability, but a disinclination. Journal of Autism and Developmental Disorders, 43(10), 2329-2340. https://doi.org/10.1007/s10803-013-1777-z

Lam, Y. G. (2014). Pragmatic language in autism: An overview. W: V. Patel, V. Preedy, C. Martin (red.), Comprehensive guide to autism (s. 533-550). Nowy Jork: Springer. https://doi.org/10.1007/978-1-4614-4788-7_25

Leinonen, E., Letts, C., Smith, B. R. (2000). Children's pragmatic communication difficulties. Londyn-Filadelfia: Whurr.

Lord, C., Rutter, M., Dilavore, P. C., Risi, S., Gotham, K., Bishop, S. L. (2012). Autism Diagnostic Observation Schedule, Second Edition (ADOS-2) Manual (Part I): Modules 1-4. Torrance: Western Psychological Services.

Maenner, M. J., Shaw, K. A., Baio, J., Washington, A., Patrick, M., DiRienzo, M., ..., Dietz, P. M. (2020). Prevalence of autism spectrum disorder among children aged 8 years - autism and developmental disabilities monitoring Network, 11 Sites, United States, 2016. Morbidity and mortality weekly report. MMWR Surveillance Summaries, 69(4), 1-12. https://doi.org/10.15585/mmwr.ss6904a1

Mayes, S. D., Calhoun, S. L., Murray, M. J., Ahuja, M., Smith, L. A. (2011). Anxiety, depression, and irritability in children with autism relative to other neuropsychiatric disorders and typical development. Research in Autism Spectrum Disorders, 5(1), 474-485. https://doi.org/10.1016/j.rasd.2010.06.012

Mäkinen, L., Loukusa, S., Leinonen, E., Moilanen, I., Ebeling, H., Kunnari, S. (2014). Characteristics of narrative language in autism spectrum disorder: Evidence from the Finnish. Research in Autism Spectrum Disorders, 8(8), 987-996. https://doi. org/10.1016/j.rasd.2014.05.001 
Norbury, C. F., Bishop, D. V. (2003). Narrative skills of children with communication impairments. International Journal of Language \& Communication Disorders, 38(3), 287-313. https://doi.org/10.1080/136820310000108133

Pennebaker, J. W. (2011). The secret life of pronouns: What our words say about us. Nowy Jork: Bloomsbury Press.

Peristeri, E., Andreou, M., Tsimpli, I. M. (2017). Syntactic and story structure complexity in the narratives of high- and low-language ability children with autism spectrum disorder. Frontiers in Psychology, 8, 2027. https://doi.org/10.3389/fpsyg.2017.02027

Peristeri, E., Baldimtsi, E., Andreou, M., Tsimpli, I. M. (2020). The impact of bilingualism on the narrative ability and the executive functions of children with autism spectrum disorders. Journal of Communication Disorders, 85, 105999. https://doi. org/10.1016/j.jcomdis.2020.105999

Piszczek, M. (2013). Wczesne wspomaganie rozwoju - najczęściej popełniane błędy. W: B. Cytowska, B. Winczura (red.), Wczesna interwencja i wspomaganie rozwoju małego dziecka (s. 81-100). Kraków: Wydawnictwo Impuls.

Rosello, B., Berenguer, C., Baixauli, I., García, R., Miranda, A. (2020). Theory of mind profiles in children with autism spectrum disorder: Adaptive/Social skills and pragmatic competence. Frontiers in Psychology, 11, 567401. https://doi.org/10.3389/ fpsyg.2020.567401

Sah, W.-H., Torng, P.-C. (2015). Narrative coherence of Mandarin-speaking children with high-functioning autism spectrum disorder: An investigation into causal relations. First Language, 35(3), 189-212. https://doi.org/10.1177/0142723715584227

Schoen-Simmons, E., Paul, R., Volkmar, F. (2014). Assessing pragmatic language in autism spectrum disorder: The Yale in vivo Pragmatic Protocol. Journal of Speech Language and Hearing Research, 57(6), 2162-2173. https://doi.org/10.1044/2014_ JSLHR-L-14-0040

St Clair, M. C., Pickles, A., Durkin, K., Conti-Ramsden, G. (2011). A longitudinal study of behavioral, emotional and social difficulties in individuals with a history of specific language impairment (SLI). Journal of Communication Disorders, 44(2), 186-199. https://doi.org/10.1016/j.jcomdis.2010.09.004

Tager-Flusberg, H. (1995). „Once upon a ribbit”: Stories narrated by autistic children. British Journal of Developmental Psychology, 13(1), 45-59. https://doi.org/10.1111/ j.2044-835x.1995.tb00663.x

Tager-Flusberg, H., Joseph, R., Folstein, S. (2001). Current directions in research on autism. Mental Retardation and Developmental Disabilities Research Reviews, $7(1), 21-29$.

Tager-Flusberg, H., Sullivan, K. (1995). Attributing mental states to story characters: A comparison of narratives produced by autistic and mentally retarded 
individuals. Applied Psycholinguistics, 16(3), 241-256. http://dx.doi.org/10.1017/ S0142716400007281

Wetherby, A. M. (2006). Understanding and measuring social communication in children with autism spectrum disorders. W: T. Charman, W. Stone (red.), Social \& communication development in autism spectrum disorders: Early identification, diagnosis, \& intervention (s. 3-28). Nowy Jork-Londyn: The Guilford Press.

Wetherby, A. M., Prizant, B. M., Hutchinson, T. (1998). Communicative, social/ affective, and symbolic profiles of young children with autism and pervasive developmental disorder. American Journal of Speech-Language Pathology, 7(2), 79-91. https://doi.org/10.1044/1058-0360.0702.79

Wetherby, A. M., Woods, J., Allen, L., Cleary, J., Dickinson, H., Lord, C. (2004). Early indicators of autism spectrum disorders in the second year of life. Journal of Autism and Developmental Disorders, 34(5), 473-493. https://doi.org/10.1007/ s10803-004-2544-y

World Health Organization. (2018). International statistical classification of diseases and related health problems. Pobrane $\mathrm{z:}$ https://icd.who.int/browse11/1-m/en 

EWA MaLinOWSKA (iD https://orcid.org/0000-0002-0881-1401

Wydział Psychologii, Uniwersytet Warszawski

\section{Neuropsychologiczna charakterystyka dynamiki zmian funkcji wykonawczych u pacjentów po lekkich urazach czaszkowo-mózgowych okolic czołowych}

Neuropsychological characteristics of the dynamics of changes in executive functions in patients with mild traumatic brain injuries of the frontal areas

Sposób cytowania: Malinowska, E. (2021). Neuropsychologiczna charakterystyka dynamiki zmian funkcji wykonawczych u pacjentów po lekkich urazach czaszkowo-mózgowych okolic czołowych. W: M. Huflejt-Łukasik, A. Pluta (red.), Mechanizmy psychologiczne i społeczne warunkujace formułowanie ocen oraz podejmowanie działań (s. 179-202). Warszawa: Wydawnictwo Liberi Libri. https://doi.org/10.47943/ lib.9788363487553.rozdzial09 


\section{Streszczenie}

Celem badania było przedstawienie neuropsychologicznej charakterystyki dynamiki zmian funkcji wykonawczych u pacjentów po lekkich urazach czaszkowo-mózgowych okolic czołowych.

W badaniach wzięło udział 17 pacjentów (18-73 lata) po lekkim urazie czaszkowo-mózgowym okolicy czołowej oraz 12 osób bez urazu mózgu, które zostały zakwalifikowane do grupy kontrolnej (według kryteriów: płci, wieku, poziomu wykształcenia i ręczności). Badania miały charakter podłużny, z czterema pomiarami przeprowadzonymi dobę, tydzień, dwa tygodnie i około pół roku po urazie mózgu. Na każdym ze spotkań badano uwagę, zdolność do hamowania reakcji, planowanie, fluencję oraz pamięć operacyjną. Do pomiaru ww. funkcji poznawczych wykorzystano odpowiednio: Test fluencji werbalnej (Lezak, Howieson, Bigler, Tranel, 2012), Odejmowanie seryjne wspak (Ruesch, 1944), Testy uwagi i spostrzegawczości (TUS; Ciechanowicz, Stańczak, 2006), Test łączenia punktów (Trail Making Tests, TMT) część A i część B (Kądzielawa, 1990), Test Wieży Londyńskiej (Tower of London, ToL; Shallice, 1982), Powtarzanie cyfr i Symbole cyfr (WAIS-R; Brzeziński i in., 2004), Test Stroopa. Dodatkowo podczas pierwszego spotkania wykonywano również krótki wywiad psychologiczny oraz próbę kliniczną polegającą na wyborze przez pacjenta interpretacji przysłów (Kordys, Ulatowska, Kądzielawa, Sadowska, 2001). Na ostatnim spotkaniu wykonywano Test sortowania kart Wisconsin (Wisconsin Card Sorting Test, WCST; Jaworowska, 2002).

Analiza statystyczna wyników ilościowych w postaci szeregów czasowych, przeprowadzona $\mathrm{z}$ wykorzystaniem hierarchicznych modeli liniowych (HLM), ujawniła istotne różnice między grupą pacjentów a grupą kontrolną przede wszystkim w zakresie takich funkcji jak: fluencja słowna, szybkość przetwarzania informacji, uwaga, pamięć operacyjna.

$\mathrm{W}$ poprawie funkcji z czasem istotną zmienną okazywała się lokalizacja lezji (półkula lewa, półkula prawa, obie półkule), jak również interakcja czasu dokonywania pomiarów i miejsca uszkodzenia. Dyskusja wyników przedstawiona jest m.in. na tle badań dotyczących 
patofizjologii fazy ostrej i podostrej urazu na poziomie komórkowym, jak również zjawisk neuroplastyczności i regeneracji tkanki nerwowej w ośrodkowym układzie nerwowym (OUN).

Słowa kluczowe: funkcje wykonawcze, płaty czołowe, badania podłużne, lekki uraz czaszkowo-mózgowy

\section{Abstract}

The goal of the project was to describe the dynamics of executive functioning changes after frontal lobes mild traumatic brain injury (mTBI).

There were 17 patients taking part in the study (aged 18-73), who suffered from frontal lobes mTBI together with 12 people included into the control group; according to their sex, age, education and handness. The research had longitudinal character, with four sessions of executive functions (EF) neuropsychological assessment conducted within $24 \mathrm{~h}$, a week, two weeks and six months after acquired mTBI. During each meeting the following methods and tests were used: Verbal fluency test (Lezak, Howieson, Bigler, Tranel, 2012), Serial substructing (Ruesch, 1944), Testy uwagi i spostrzegawczości (TUS; Ciechanowicz, Stańczak, 2006), Trail making test (TMT) part A and part B (Kądzielawa, 1990); Tower of London (ToL; Shallice, 1982), Digit Span, Digit Symbol Coding (WAIS-R; Brzeziński i in., 2004), Stroop Test and Wisconsin Card Sorting Test (WCST; Jaworowska, 2002) during the last meeting only. First meeting was associated as well by a short psychological interview and choosing the correct interpretation of the selected proverbs (Kordys i in., 2001).

Statistical analysis (hierarchical linear models, HLM) revealed significant differences between the groups in short-term memory functions, verbal fluency, attentional control and the speed of information processing. In the process of recovery both since the onset of injury as well as its localization (left, right, or both hemispheres) and the interaction of these factors played the most important role. Results are discussed together with short characteristics of the pathophysiological processes 
of the acute and subacute brain injury phases, as well as neuroplasticity and neural regeneration processes typical for the recovery.

Keywords: executive functions, frontal lobes, longitudinal studies, mild traumatic brain injury

Temat przedstawianej pracy stanowi neuropsychologiczna dynamika zmian funkcji wykonawczych (executive functions, EF) u pacjentów po lekkich urazach czaszkowo-mózgowych (mild traumatic head injury, mTBI) okolicy czołowej.

Termin funkcje wykonawcze odnosi się do umiejętności związanych z biegłością w myśleniu, planowaniu, zarządzaniu czasem i organizacją działania, ukierunkowanego na określony cel. Efektywność tego działania zależy m.in. od: wydajności samokontroli, hamowania działań niepożądanych i sprawnych procesów pamięci operacyjnej.

EF nie tylko odpowiadają za syntezę bodźców zewnętrznych, przygotowanie i programowanie działania, ale są również krytyczne dla jego zaistnienia oraz umożliwiają weryfikację, czy objęło ono właściwy kierunek (Łuria, 1963, 1973). Roberts i Pennington (1996, s. 105) definiują funkcje wykonawcze jako: „,zdolność utrzymania odpowiedniego nastawienia, podejścia ukierunkowanego na zdobycie przyszłego celu"; na które to składają się powstrzymanie (hamowanie zachowań konkurencyjnych), strategiczne planowanie przyszłego działania oraz utrzymanie umysłowej reprezentacji pożądanego i wytyczonego celu. Wynika $\mathrm{z}$ tego, że funkcje wykonawcze stanowią zbiór powiązanych ze sobą procesów umożliwiających realizację na różnych etapach określonych intencji - procesów, co do których nawiązuje się niekiedy jako do „dowódcy”, kontrolującego, organizującego oraz kierującego działaniem poznawczym, zachowaniem, a także emocjami (Gioia, Isquith, Guy, 2001). Funkcje wykonawcze nie ograniczają się bowiem jedynie do poznawczej domeny funkcjonowania („cold” executive processes), ale są również zaangażowane w procesy regulacji afektu i motywacji („hot” executive processes; Zelazo, Qu, Müller, 2005). EF stanowią również istotną podstawę efektywnych interakcji społecznych (López-Navarro, 2018; Madjar, Chubarov, Zalsman, Weiser, Shoval, 2019; Perry i in., 2019). 
Do kluczowych komponentów funkcji wykonawczych zalicza się (Anderson, 2008):

- czujność i zaangażowanie procesów uwagi,

- kontrolę impulsów i samokontrolę,

- inicjację działania,

- pamięć operacyjną,

- zdolność planowania i organizacji,

- elastyczność zachowań oraz umiejętność wykorzystywania informacji zwrotnych,

- wybór skutecznych strategii rozwiązywania problemów.

Podsumowując, funkcje wykonawcze można rozumieć jako złożony układ współzależnych od siebie zdolności i umiejętności przyczyniających się do zachowań umożliwiających osiągnięcie celu (Lezak, 1995), aktywowanych najczęściej w nowych, nieznanych dotychczas okolicznościach, dla których nie wytworzył się jeszcze skrypt postępowania (Shallice, 1990) i krytycznych dla adaptacji do otoczenia.

Do najważniejszych okolic mózgowych związanych z EF należą płaty czołowe, które wciąż uważa się za jedną z głównych okolic odpowiadających za ich prawidłowy przebieg (np. Alvarez, Emory, 2006; Anderson, 2008; Cummings, Miller, 2007; Stuss, Alexander, 2000; Tsuchida, Fellows, 2013). W związku z tym podstawowym kryterium rekrutacji badanych do omawianego projektu był uraz okolicy czołowej. Należy jednak w tym miejscu zaznaczyć, że płaty czołowe nie stanowią z pewnością jedynej okolicy zaangażowanej w przebieg EF (Takeuchi i in., 2013).

Pewne rozbieżności dotyczące wyników przedstawianych prac wiążą się nie tylko z utożsamianiem funkcji wykonawczych i tzw. „funkcji czołowych”, ale również metodologią ich badania, tj. różnymi kryteriami, które należy uwzględniać przy pomiarze EF, a co za tym idzie w konsekwencji określonymi metodami i narzędziami, którymi można się posługiwać przy ich diagnozie. Specyfika pomiaru funkcji wykonawczych w idealnej sytuacji wymaga nie tylko zastosowania podejścia ekologicznego (Chaytor, Schitter-Edgecomb, Burr, 2006; Zartman, Hilsabeck, Guarnaccia, Houtz, 2013), umożliwiającego obserwację ewentualnych zaburzeń w sytuacjach zbliżonych jak najbardziej do tych z życia codziennego, ale również spełnienia np. kryterium nowości proponowanego zadania nie tylko pod względem treści, ale i formy (Dencla, 1994). Sprawia to, że prawidłowa diagnoza EF, przy jednoczesnych problemach trafności i rzetelności stosowanych narzędzi, może być jednym z największych wyzwań dla neuropsychologa. 
Ze względu na swoją charakterystykę funkcje wykonawcze wydają się być jednymi z kluczowych w procesie rehabilitacji neuropsychologicznej. W jej przebiegu kładzie się nacisk m.in. na wzmacnianie samoświadomości, ustanawianie celów w codziennym funkcjonowaniu - np. przygotowanie posiłku, ćwiczenie umiejętności rozwiązywania problemów, podejmowanie decyzji (Kennedy i in., 2008; Novakovic-Agopian i in., 2014; Wheeler, 2014). Powstają programy, w których pacjentom proponuje się trening funkcji uwagi czy regulacji procesów emocjonalnych (Gordon, 2013; por. Cantor i in., 2013). Rehabilitacja neuropsychologiczna EF obejmuje swoim zakresem zazwyczaj okres kilku tygodni (faza intensywna), w dalszej kolejności może być prowadzona przez kilka, kilkanaście miesięcy w trybie cotygodniowych spotkań (Wilson, Gracey, Evans, Bateman, 2009; Wilson, Winegardner, van Heugten, Ownsworth, 2017).

Biorąc pod uwagę liczne rozbieżności związane $\mathrm{z}$ diagnozą i postępowaniem po lekkim urazie czaszkowo-mózgowym, przy równoczesnym braku jednoznacznych odpowiedzi uzyskiwanych dzięki np. metodom neuroobrazowania (przegląd w: Eirud i in., 2014), postanowiono sprawdzić, jaką szansę na pośrednią obserwację i wnioskowanie o zmianach zachodzących w OUN u pacjentów po lekkich urazach czaszkowo-mózgowych stwarzają metody i narzędzia neuropsychologiczne.

U podłoża takiego stanu rzeczy leżą zarówno wdrażane w tym okresie niezbędne procedury medyczne (np. zabiegi operacyjne czy leki), jak i sam stan pacjentów (np. wstrząśnienie mózgu, pourazowe przekrwienia i obrzęk mózgu; Prusiński, 2007). Co więcej, jedynie nieliczne publikacje poświęcone są badaniom podłużnym z uwzględnieniem okresu ostrego (Landry-Roy $\mathrm{i}$ in., 2018), a pojedyncze pozycje traktują o badaniach $w$ okresie ostrym $\mathrm{z}$ równoczesnym uwzględnieniem patofizjologii urazu oraz zachodzących równolegle procesów neuroregeneracji tkanki nerwowej i pośrednio związanych z nią zjawisk neuroprotekcji (Bigler, Maxwell, 2012)

Jak wskazują badania z zakresu patofizjologii mTBI, większość neuronów po urazie nie zostaje zniszczona, a zaburzone zostaje ich funkcjonowanie (Inverson, 2005). U podstaw konsekwencji urazów czaszkowo-mózgowych obserwowanych na poziomie neurobehawioralnym leżą procesy, które zachodzą bezpośrednio na poziomie komórkowym.

Podczas trwania fazy ostrej ${ }^{1}$, w pierwszej godzinie po wystąpieniu urazu, ma miejsce uwolnienie do przestrzeni międzysynaptycznych wysokich stężeń neuroprzekaźnika - glutaminianu, który aktywuje znajdujące się na błonie postsynap-

$1 \mathrm{~W}$ odniesieniu do procesów zachodzących na poziomie komórkowym faza ostra przypada na czas kilku, kilkunastu godzin po urazie. W odniesieniu do procesów diagnozy i rehabi- 
tycznej receptory NMDA (rodzaj receptora dla glutaminianu, który jest selektywnie aktywowany przez kwas $\mathrm{N}$-metylo-D-asparaginowy). W konsekwencji dochodzi do:

- uwolnienia do przestrzeni międzykomórkowej dużych stężeń jonów potasu (K+) i napływu do komórki jonów sodu (Na+; Katayama i in., 1990);

- akumulacji międzykomórkowych jonów wapnia $\left(\mathrm{Ca}_{2}+\right)$, co przyczynia się w dalszej konsekwencji do ich wychwytu przez mitochondria, a to z kolei leży u podstaw zjawiska tzw. stresu oksydacyjnego i powstawania wysokich stężeń wolnych rodników - cząsteczek bardzo szkodliwych dla komórki (Peng, Jou, 2010; Xiong, Gu, Peterson, Muizelaar, Lee, 1997);

- zwiększenia aktywności pompy sodowo-potasowej na błonie presynaptycznej, która dążąc do przywrócenia stanu równowagi jonowej, zużywa duże zapasy energii, które dla każdej z komórek stanowi adenozynotrifosforan (ATP), powstający głównie z przemian glukozy.

Opisane pokrótce zmiany metaboliczne wraz ze zmianami dotyczącymi mózgowego przepływu krwi przedstawia poniższy wykres (rysunek 1; zmodyfikowane za: Giza, Hovda, 2001).

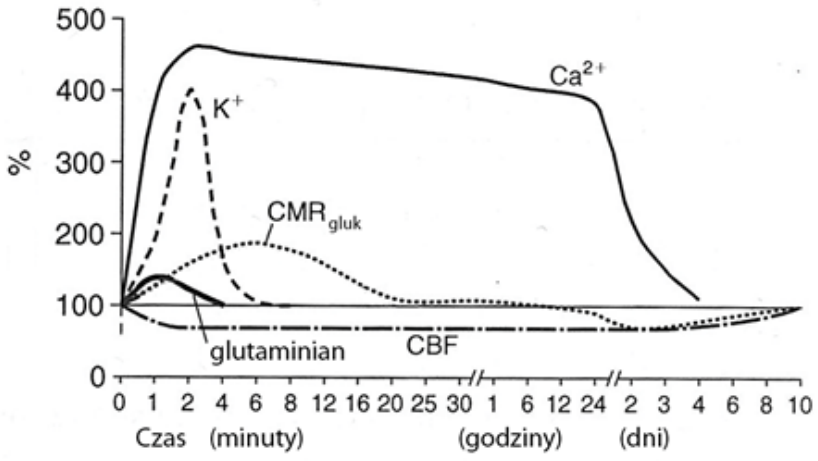

Rysunek 1. Kaskada neurometaboliczna występująca na skutek eksperymentalnego urazu czaszkowo-mózgowego (mTBI).

Adnotacja. K+ - potas; Ca + - wapń; CMRgluc - metabolizm tlenowy glukozy; CBF - mózgowy przepływ krwi (zmodyfikowane za: Giza, Hovda, 2001).

litacji neuropsychologicznej - faza ostra obejmuje pierwsze godziny i dni po urazie, a faza podostra - kilka pierwszych tygodni po urazie (Kużdżał, Magoń, 2018). 
Podsumowując, literatura przedmiotu proponuje różne rozwiązania związane z diagnozą i rehabilitacją EF w pewnym okresie po doświadczonym TBI. We współczesnym piśmiennictwie nie spotkałam się z żadną pracą, która traktowałaby o ocenie dynamiki zmian EF we wczesnym okresie po lekkim urazie czaszkowo-mózgowym. Brakuje jednoznacznych wytycznych co do oceny EF, kluczowej w krótkim czasie po urazie. Wyniki badań różnią się od siebie w związku z przypisywaniem odmiennych korelatów mózgowych EF, różnych definicji mTBI czy stosowanych metod diagnozy wymagających ekologicznego podejścia.

Głównym celem omawianego projektu badań jest zatem określenie dynamiki zmian funkcji wykonawczych u osób dorosłych po lekkich urazach czaszkowo-mózgowych płatów czołowych.

Zakłada się, że u pacjentów po lekkim urazie czaszkowo-mózgowym płatów czołowych:

1. można zaobserwować deficyty w zakresie takich zmiennych charakteryzujących funkcje wykonawcze, jak: kontrola procesów uwagi, kontrola impulsów i samokontrola, inicjacja działania, pamięć operacyjna, zdolność planowania i organizacji, elastyczność zachowania oraz umiejętność wykorzystywania informacji zwrotnych czy wybór skutecznej strategii rozwiązywania problemów;

2. w każdym $\mathrm{z}$ kolejnych planowanych pomiarów przewiduje się polepszenie wyników w obrębie badanych aspektów funkcji wykonawczych w czasie, o czym wnioskować będzie można na podstawie obserwacji wskaźników dla wykorzystywanych metod.

\section{MetodA}

\section{Kryteria doboru osób badanych i ich charakterystyka}

W badaniu wzięło udział łącznie 29 osób, z czego 17 stanowiło grupę kliniczną, a 12 grupę kontrolną. Grupę kliniczną stanowiły osoby po przebytym urazie czaszkowo-mózgowym okolic czołowych (prawej, lewej, bądź obu półkuli) widocznym na zdjęciach tomografii komputerowej, bez innych stwierdzonych obrażeń w obrębie ośrodkowego lub obwodowego układu nerwowego czy innych poważnych urazów ciała (układu kostnego, narządów wewnętrznych itp.). 
Wskaźnik Skali śpiączki Glasgow (GCS) w momencie przyjęcia do szpitala wynosił 13-15 pkt., czas trwania śpiączki poniżej $15 \mathrm{~min}$. od urazu, z amnezją pourazową (PTA) nieprzekraczającą $24 \mathrm{~h}$ od urazu, co pozwalało klasyfikować uraz jako lekki.

Na podstawie wywiadu ustalono, że osoby z grupy klinicznej nie cierpiały na ostre lub przewlekłe schorzenia układów krążenia, odpornościowego, oddechowego, pokarmowego. Nie stwierdzano zaburzeń o charakterze hormonalnym. Żaden $\mathrm{z}$ wywiadów nie ujawniał również chorób nowotworowych czy zaburzeń psychicznych.

Kryterium włączenia osób do grupy kontrolnej był brak deklarowanych urazów OUN, jak również innych schorzeń układów wymienianych powyżej. Osoby z grupy kontrolnej zostały dobrane odpowiednio do każdego z pacjentów pod względem: wieku, płci, ręczności oraz wykształcenia. Żaden z pacjentów w okresie prowadzenia badań nie podlegał ustrukturalizowanym oddziaływaniom w zakresie rehabilitacji neuropsychologicznej. W przypadku dwóch pacjentów (którzy wraz z rodzinami wyrazili taką chęć) spotkaniom diagnostycznym towarzyszyły dwa spotkania o charakterze wspomagającym pacjenta w aktywnościach życia codziennego (np. wskazówki co do tego, jak ustalać plan dnia, robić listę zakupów itd.). Działania te nie miały jednak wpływu na wyniki badań diagnostycznych EF.

\section{Przebieg i organizacja badań}

Pierwsze spotkanie z osobami z grupy klinicznej odbywały się na terenie placówki medycznej, kolejne na terenie Wydziału Psychologii Uniwersytetu Warszawskiego lub miejscu zamieszkania osoby badanej. Łącznie odbyły się 4 spotkania w następujących punktach czasowych:

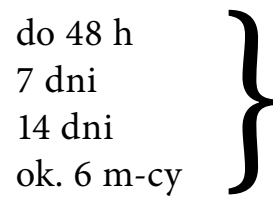

Badania postanowiono przeprowadzić w fazie ostrej (pierwsze do $48 \mathrm{~h}$ po urazie, drugie 7 dni po urazie) i podostrej (14 dni od wystąpienia urazu; Desrosiers, Bourbonnais, Corriveau, Gosselin, Bravo, 2005), a także w okresie po potwierdzonym urazie czaszkowo-mózgowym okolicy czołowej 
spodziewanego powrotu do poziomu funkcjonowania sprzed urazu - około pół roku po zdarzeniu (Johansson, Berglund, Ronnback, 2009).

\section{Metody badania}

Z uwagi na fakt, że grupę kliniczną stanowiły osoby po urazach czaszkowo-mózgowych, charakteryzujące się szybką męczliwością, oraz na możliwość wystąpienia w badaniach efektu wprawy (wynikającym $\mathrm{z}$ wielokrotnego badania każdej osoby) zdecydowano się na następujący dobór metod i narzędzi (w nawiasach przedstawiono najważniejsze z mierzonych komponentów EF):

- przy pierwszym spotkaniu krótki wywiad psychologiczny związany z sytuacją doświadczenia urazu;

- wybór interpretacji przysłów (próba eksperymentalna; Kordys i in., 2001) - rozumienie treści abstrakcyjnych i konkretnych;

- Odejmowanie seryjne wspak (od 100 po 7; Ruesch, 1944) - pamięć operacyjna i uwaga;

- Powtarzanie cyfr (podtest WAIS-R; Brzeziński i in., 2004) - zakres i pojemność uwagi, pamięć operacyjna;

- Test fluencji werbalnej (Lezak i in., 2012) - płynność werbalna;

- Symbole cyfr (podtest WAIS-R; Brzeziński i in., 2004) - koncentracja, pamięć, koordynacja wzrokowo-ruchowa;

- Testy uwagi i spostrzegawczości TUS (wykorzystanie trzech wersji równoległych; Ciechanowicz, Stańczak, 2006) - szybkość dokładnej percepcji;

- Test łączenia punktów (wersja A i B; Trail Making Test, TMT; Kądzielawa, 1990) - czujność i zaangażowanie procesów uwagi (A i B), inhibicja bodźców konfliktowych (B);

- Test Wieży Londyńskiej (Tower of London, ToL; Shallice, 1982) - planowanie;

- Test Stroopa (jako metoda) - hamowanie reakcji niepożądanej;

- na ostatnim spotkaniu: Test sortowania kart Wisconsin (Wisconsin Card Sorting Test, WCST) - pomiar zdolności rozumowania abstrakcyjnego, umiejętność wykorzystania informacji zwrotnej, elastyczność reakcji (Jaworowska, 2002).

W przypadku każdego z pacjentów przyjęciu na oddział towarzyszyła ocena Skali śpiączki Glasgow (GCS) oraz badania CT. 


\section{Schemat badania}

Jak pokazują badania, większość metod stosowana w powyższej pracy, np. testy TMT, fluencja, test seryjnego odejmowania i wykorzystywane podtesty WAIS-R czy test ToL (Berg, Byrd, McNamara, Case, 2010), wydaje się podlegać umiarkowanemu efektowi wprawy (Bartels, Węgrzyn, Wiedl, Ackerman, Eherenreich, 2010; Beglinger i in., 2005; Bird, Papadopoulou, Ricciardelli, Rossor, Cipolotti, 2004; Lezak, 2004) lub też wcale mu nie podlegać (Basso, Bornstein, Lang, 1999). Tak nie jest w przypadku testu WCST, dlatego pomiaru z wykorzystaniem tego testu dokonywano jednokrotnie - podczas ostatniego spotkania (Bartels i in., 2010; Basso i in., 2010; Bird i in., 2004) - czy Testu Stroopa, wykonywanego w trakcie każdego ze spotkań (Beglinger i in., 2005; Clawson, 2002).

Pragnąc zrównoważyć efekty wynikające z kolejności pojawiania się pomiarów różnych zmiennych $\mathrm{w}$ badaniach $\mathrm{z}$ powtarzanymi pomiarami, zdecydowano się na wykorzystanie planu opartego na kwadracie łacińskim ${ }^{2}$ (Fisher, Yates, 1963). Zastosowanie losowej kolejności wykorzystywanych metod miało na celu zminimalizować ryzyko wystąpienia efektu wprawy, pojawiającego się wraz z rozwiązywaniem kolejnych testów w trakcie jednej sesji.

Pomiary przeprowadzono według planów różnych kwadratów łacińskich (trzy dla grupy kontrolnej i pięć dla grupy klinicznej, odmiennych w każdym z czterech pomiarów; co łącznie dało 32 plany), dobranych dla każdej z grup niezależnie metodą losową (tablice: Fisher, Yates, 1963).

Chcąc dodatkowo zabezpieczyć się przed wpływem niekontrolowanych zmiennych, w modelach kontrolowano kowariancję reszt regresji pomiędzy każdym z pomiarów. Uzyskanie w przypadku któregokolwiek z modeli istotnej zależności lub wyraźnego wzoru zależności mogłoby sugerować istnienie takiej zmiennej. Jako że obserwacja taka nie znalazła odbicia w układzie wyników, zakłada się brak podstaw do stwierdzenia efektu wprawy.

\footnotetext{
2 Plany kwadratu łacińskiego stosuje się do: (1) kontrolowania ewentualnej stronniczości wynikającej ze zmiennych, które można podejrzewać o to, że korelują ze zmienną zależną, ale same nie stanowią głównego punktu zainteresowania; (2) uproszczenia eksperymentów trój- i więcej czynnikowych przez przyjęcie zmniejszonej, specjalnie dobranej liczby grup i zestawień warunków eksperymentalnych; (3) w eksperymentach z powtarzanym pomiarem - w celu zrównoważenia efektów wynikających z kolejności występowania poszczególnych rodzajów warunku eksperymentu (Ferguson, Takane, 1999).
} 


\section{Analiza statystyczna}

Analizę statystyczną dla analizy ilościowej przeprowadzono w programie R (R Core Team, 2018).

Założenie o normalności rozkładu mierzonych zmiennych sprawdzano testem Shapiro-Wilka. Zmienne, których rozkład istotnie odbiegał od normalnego (dla $p<0,05)$, przekształcano $\mathrm{z}$ wykorzystaniem transformacji Boxa-Coxa (1964).

\section{WYNIKI}

Analizę statystyczną dla każdej mierzonej zmiennej przeprowadzono w modelu mieszanym $\mathrm{z}$ obecnością urazu płatu czołowego (dwie grupy: brak urazu vs. osoby z urazem) jako czynnikiem międzyosobowym oraz czasem od początku badania (cztery pomiary: do $48 \mathrm{~h} / 1$ tydzień / 2 tygodnie / ok. 27 tygodni po urazie) jako czynnikiem wewnątrzobiektowym.

W tabeli 1 przedstawiono wyniki poszczególnych testów dla grupy kontrolnej i klinicznej oraz testy różnic pomiędzy wymienionymi grupami w każdym z czterech pomiarów. Ze względu na znaczny odsetek braków danych spowodowany osobami rezygnującymi z badania, zamiast standardowej ANOVY przy analizie statystycznej zastosowano hierarchiczne modele liniowe. W dodatkowym kroku, aby kompleksowo ocenić, na ile grupy różniły się w każdym pomiarze, dla wszystkich mierzonych zmiennych obliczono współczynnik $\lambda$ Wilksa. Jest on stosowany $w$ wielowymiarowej analizie wariancji do jednoczesnego porównywania ze sobą wielu potencjalnie skorelowanych zmiennych. Oszacowania wartości $\lambda$ oraz testy wielowymiarowych różnic pomiędzy grupą osób z urazem oraz grupą kontrolną przedstawiono w tabeli 2. 
Tabela 1

Wyniki poszczególnych metod i testów u osób z urazem płata czołowego i grupy kontrolnej w jednowymiarowej analizie wariancji (ANOVA) w kolejnych pomiarach (do 48h po urazie [1]; 1 tydzien po urazie [2]; 2 tygodnie po urazie [3]; około 27 tygodni po urazie [4]); df dla poszczególnych pomiarów jak w tabeli 2)

\begin{tabular}{|c|c|c|c|c|c|c|c|c|c|c|c|c|}
\hline \multirow{3}{*}{ Metoda } & \multicolumn{6}{|c|}{ Pomiar 1} & \multicolumn{6}{|c|}{ Pomiar 2} \\
\hline & \multicolumn{2}{|c|}{ Kontrola } & \multicolumn{2}{|c|}{$\begin{array}{c}\text { Grupa } \\
\text { kliniczna }\end{array}$} & \multicolumn{2}{|c|}{ Wartość } & \multicolumn{2}{|c|}{ Kontrola } & \multicolumn{2}{|c|}{$\begin{array}{c}\text { Grupa } \\
\text { kliniczna }\end{array}$} & \multicolumn{2}{|c|}{ Wartość } \\
\hline & M & SD & $M$ & SD & $\boldsymbol{F}$ & $p$ & $M$ & SD & $M$ & SD & $\boldsymbol{F}$ & $p$ \\
\hline Test fluencii słowne & 13,3 & 3,6 & 10,5 & 3,52 & 2,39 & 0,04 & 15,88 & 1,90 & 10,53 & 4,55 & 7,75 & 0,009 \\
\hline Powtarzanie cyfr & 12,0 & 2,1 & 9,9 & 3,51 & 5,14 & 0,03 & 11,75 & 2,87 & 10,71 & 2,91 & 1,63 & 0,19 \\
\hline Symbole cyfr & 11,5 & 2,7 & 9,1 & 3,34 & 5,66 & 0,02 & 12,00 & 2,62 & 10,31 & 4,08 & 0,66 & 0,42 \\
\hline Test Stroopa (błędy & 0,5 & 0,5 & 1,5 & 1,91 & 7,03 & 0,01 & 0,25 & 0,46 & 1,29 & 1,79 & 0,95 & 0,33 \\
\hline TMT część A & 53,8 & 9,9 & 56,3 & 8,57 & 0,56 & 0,45 & 50,00 & 3,02 & 52,00 & 6,29 & 0,62 & 0,43 \\
\hline TMT część B & 49,7 & 2,7 & 47,1 & $9 \quad 13,07$ & 0,91 & 0,34 & 47,00 & 2,20 & 49,50 & 5,80 & 0,09 & 0,76 \\
\hline ToL (śr. ruchów) & 8,9 & 2,4 & 8,2 & 1,87 & 0,62 & 0,43 & 9,14 & 2,01 & 8,67 & 2,69 & 0,25 & 0,61 \\
\hline TUS Szybkość & 3,7 & 1,1 & 3,4 & 1,93 & 0,004 & 0,94 & 4,25 & 1,58 & 4,44 & 1,97 & 0,05 & 0,81 \\
\hline \multirow[t]{2}{*}{ TUS Opuszzzenia } & 2,5 & 0,7 & 2,0 & 0,93 & 1,65 & 0,21 & 1,88 & 0,64 & 2,31 & 0,79 & 11,57 & 0,002 \\
\hline & \multicolumn{6}{|c|}{ Pomiar 3} & \multicolumn{6}{|c|}{ Pomiar 4} \\
\hline \multirow[t]{2}{*}{ Metoda } & \multicolumn{2}{|c|}{ Kontrola } & \multicolumn{2}{|c|}{$\begin{array}{c}\text { Grupa } \\
\text { kliniczna }\end{array}$} & \multicolumn{2}{|c|}{ Wartość } & \multicolumn{2}{|c|}{ Kontrola } & \multicolumn{2}{|c|}{$\begin{array}{c}\text { Grupa } \\
\text { kliniczna }\end{array}$} & \multicolumn{2}{|c|}{ Wartość } \\
\hline & $M$ & SD & $M$ & SD & $\boldsymbol{F}$ & $p$ & $M$ & SD & $M$ & SD & $\boldsymbol{F}$ & $p$ \\
\hline $\begin{array}{l}\text { Test fluencij } \\
\text { stownej }\end{array}$ & 13,88 & 2,20 & 10,82 & 4,48 & 7,39 & 0,01 & 14,38 & 2,39 & 13,00 & 4,56 & 1,38 & 0,24 \\
\hline Powtarzanie cyfr & 11,75 & 2,43 & 11,82 & 2,74 & 0,16 & 0,69 & 11,38 & 2,45 & 12,65 & 2,74 & 2,84 & 0,1 \\
\hline Symbole cyfr & 10,75 & 3,49 & 11,25 & 4,20 & 0,49 & 0,48 & 11,25 & 2,71 & 12,75 & 4,14 & 3,27 & 0,08 \\
\hline $\begin{array}{l}\text { Test Stroopa } \\
\text { (błędy) }\end{array}$ & 0,38 & 0,52 & 0,71 & 0,99 & 0,68 & 0,41 & 0,13 & 0,35 & 0,41 & 0,51 & 3,12 & 0,08 \\
\hline TMT część A & 52,38 & 7,01 & 55,69 & 14,59 & 0,02 & 0,88 & 49,38 & 3,38 & 51,86 & 8,87 & 2,06 & 0,16 \\
\hline TMT część B & 48,00 & 2,67 & 50,00 & 6,67 & 1,11 & 0,3 & 48,00 & 2,77 & 49,14 & 4,49 & 3,47 & 0,07 \\
\hline ToL (śrr. ruchów) & 8,97 & 2,01 & 8,65 & 1,99 & 0,11 & 0,74 & 9,58 & 1,99 & 8,38 & 2,41 & 1,69 & 0,2 \\
\hline TUS Szybkość & 4,00 & 1,60 & 3,69 & 2,50 & 3,76 & 0,06 & 4,00 & 1,60 & 4,88 & 2,31 & 4,36 & 0,04 \\
\hline TUS Opuszczenia & 1,25 & 0,71 & 2,56 & 1,09 & 15,91 & 0,001 & 1,00 & 0,00 & 2,00 & 0,89 & 11,48 & 0,002 \\
\hline
\end{tabular}


Dane w wielowymiarowej analizie wariancji MANOVA (tabela 2) uzyskano testując jednocześnie różnice pomiędzy obiema grupami osób (kontrolną vs. kliniczną) $\mathrm{w}$ każdym $\mathrm{z}$ czterech pomiarów na wszystkich mierzonych zmiennych. Analizy wykonano dla zmiennych zależnych stanowiących wyniki poszczególnych testów: Testu fluencji słownej, testu Powtarzanie cyfr, testu Symbole cyfr, Testu Stroopa (liczba błędów), TMT (części A i B), ToL (średnia liczba ruchów) i testów TUS (szybkość i liczba opuszczeń). Wartość testu $F$ ujmuje różnicę na poziomie wszystkich zmiennych zależnych pomiędzy grupą osób z urazem i grupą kontrolną. Lambda ( $\lambda$ Wilksa) stanowi miarę procentowej wariancji zmiennych zależnych niewyjaśnionej przez różnice w poziomach zmiennej niezależnej.

Tabela 2

Zróżnicowanie wyników osób z urazem płata czołowego i grupy kontrolnej oszacowane z wykorzystaniem wielowymiarowej analizy wariancji (MANOVA) w kolejnych pomiarach (do 48h po urazie [1]; 1 tydzień po urazie [2]; 2 tygodnie po urazie [3]; około 27 tygodni po urazie [4])

\begin{tabular}{lcccc}
\hline Pomiar & Df & $\boldsymbol{F}$ & $\boldsymbol{p}$ & $\lambda$ Wilksa \\
\hline 1 & 24 & 2,87 & 0,031 & 0,38 \\
2 & 26 & 2,61 & 0,039 & 0,43 \\
3 & 22 & 5,86 & 0,001 & 0,20 \\
4 & 18 & 4,06 & 0,01 & 0,21 \\
\hline
\end{tabular}

Jeśli przyjrzeć się ogólnemu zróżnicowaniu wyników, to ich największą wariancję przy podziale na grupę kliniczną i kontrolną można obserwować $\mathrm{w}$ trzecim pomiarze, $\mathrm{tj}$. pomiarze dokonywanym na około 2 tygodnie po urazie doświadczonym przez grupę pacjentów. Inaczej ujmując, największe różnice między grupami wystąpiły na około 2 tygodnie po doświadczonym urazie $\left(\lambda_{\text {wilks }}=0,20\right)$. Grupy różniły się od siebie $\mathrm{w}$ najmniejszym stopniu $\mathrm{w}$ drugim pomiarze, tj. na około tydzień po doświadczonym urazie $\left(\lambda_{\text {Wilksa }}=0,43\right)$. Zróżnicowanie wyników między pacjentami i osobami z grupy kontrolnej plasowało się na zbliżonym do siebie poziomie w pomiarach dokonywanych $\mathrm{w}$ dwa tygodnie i pół roku po urazie (odpowiednio: $\lambda_{\text {wilksa }}=0,20$ i $\lambda_{\text {wilksa }}=0,21$ ).

$\mathrm{W}$ każdym z pomiarów za istotne zróżnicowanie wyników odpowiadały wyniki otrzymywane w Teście fluencji słownej (poza pomiarem ostatnim; $p=0,04 ; p=0,009$ i $p=0,01$ ) oraz wyniki otrzymywane $\mathrm{w}$ testach TUS (poza 
pomiarem pierwszym). W przypadku testów TUS kluczowym wskaźnikiem była liczba opuszczeń ( $p=0,002 ; p=0,001 ; p=0,02$ ). W pierwszym z pomiarów na istotne zróżnicowanie wyników miały również wpływ te otrzymane w podtestach Wechslera: Powtarzanie cyfr $(p=0,03)$ i Symbole cyfr $(p=0,02)$, jak również liczba błędów popełniania w Teście Stroopa $(p=0,01)$.

\section{Dyskusja}

W przedstawionej pracy podjęto próbę scharakteryzowania dynamiki zmian funkcji wykonawczych u osób po lekkich urazach czaszkowo-mózgowych okolicy czołowej. Głównym celem badań była próba przedstawienia zmian zachodzących w ramach funkcji wykonawczych w okresie ostrym i podostrym, jak również w około pół roku po doświadczonym mTBI.

$\mathrm{W}$ literaturze poświęconej badaniom w okresie ostrym i podostrym po mTBI większość autorów skupia się na ogólnym funkcjonowaniu poznawczym i przedstawia wyniki w ramach porównań średnich, odchyleń standardowych oraz wielkości efektów opartych na średnich lub dystansie między nimi wśród wyselekcjonowanych według różnych kryteriów grup pacjentów i grup kontrolnych. W omawianym projekcie wykorzystano hierarchiczne modele liniowe wraz z analizą danych opartą na równaniach regresji. Wyniki badań neuropsychologicznych otrzymanych w pracy wydają się mieć ogólną charakterystykę zbliżoną do tych, które przedstawia się w piśmiennictwie (Gomez-de-Regil, 2020; Ozga, Povroznik, Engler-Chiurazzi, Vonder Haar, 2018)

Samoistne procesy regeneracji mogą wynikać ze zmian aktywności synaps, czy też wzmożonych procesów neurogenezy w postaci powstawania nowych połączeń, lub też wzmacniania już posiadanych, prowadzących do zmian m.in. na poziomie biochemicznym (np. blokady kwasu $\gamma$-aminomasłowego), bądź też przebudowy cytoarchitektury szkieletu komórek (np. Sacharczuk, 2005), czy wreszcie wzmożonej szeroko rozumianej aktywności komórek glejowych (Field, 2011). Nakamura, Hillary i Biswal (2009) badali sieci neuronalne w okresie od 3 do 6 miesięcy po doświadczonym urazie czaszkowo-mózgowym i stwierdził znacznie obniżoną liczbę istotnych połączeń, obniżony poziom funkcjonowania już istniejących, jak również podwyższenie wartości jednego ze wskaźników matematycznej teorii grafów, który umożliwia stwierdzenie w ilu krokach można dotrzeć do każdego $\mathrm{z}$ węzłów badanej sieci (w tym przypadku neuronów), pomimo tego, że nie znajdują się one w swoim bezpośrednim sąsiedztwie. Wyniki 
te sugerowałyby przejście z dużej dynamiki zmian na poziomie neuronalnym i elastyczności procesów we wczesnych fazach regeneracji po urazie do zwiększającej się w późniejszych etapach ich efektywności kosztem plastyczności sieci. Taka zmiana zmniejszyłaby koszty związane z procesami regeneracji i umożliwiała umocowanie się nowo powstających sieci. Powyższe wyniki uzupełniają niejako badania funkcji poznawczych prowadzone po urazach, w których wzory aktywacji wielu okolic mózgu są obecne przede wszystkim w fazie ostrej i podostrej (Barrat, Barthelemy, Pastor-Sattoras, Vespignani, 2004).

Być może w przypadku lekkich urazów mamy do czynienia z podobnym zjawiskiem, gdzie początkowo organizm mobilizuje się na tyle, że wyniki osiągane przez osoby w grupach klinicznych, w testach i metodach poświęconych funkcjom uwagi odbiegają od wyników osiąganych w grupie kontrolnej dopiero jakiś czas po doświadczonym urazie? Jeśli przyjrzeć się ogólnemu zróżnicowaniu wyników w przedstawianym projekcie, to ich największą wariancję przy podziale na grupę kliniczną i kontrolną można obserwować w trzecim pomiarze, tj. pomiarze dokonywanym na około 2 tygodnie po urazie doświadczonym przez grupę pacjentów. Grupy różniły się od siebie w najmniejszym stopniu $\mathrm{w}$ drugim pomiarze, $\mathrm{tj}$. na około tydzień po potwierdzonym urazie. Może to potwierdzać relację, w której w fazie ostrej i podostrej po urazie pozostają procesy neuroplastyczności $v s$. wspomniane powyżej typowe dla tkanki zmiany o podłożu fizjologicznym z otrzymywanymi wynikami testów i funkcjonowaniem pacjentów w obrębie EF.

Przyglądając się neuropsychologicznym konsekwencjom urazów czaszkowo-mózgowych badanych z wykorzystaniem szerokiej gamy testów i metod neuropsychologicznych, można z całą pewnością zauważyć ogromne zróżnicowanie ich wyników wśród pacjentów, w szczególności tych, których według dyskutowanych w pracy kryteriów zalicza się do grup klinicznych z lekkim urazem czaszkowo-mózgowym (Dikmen, Reitan, Temkin, 1983; Reitan, Wolfson 1986, 1988).

Williams, Levin i Eisenberg (1990), badając osoby po mTBI, przy prowadzonych porównaniach podgrup wyznaczonych na podstawie stopnia skomplikowania urazu (głębokości i rozległości uszkodzenia miąższu tkanki mózgowej) osiągali wyniki wskazujące na tak wysoki stopień zróżnicowania wśród pacjentów, że już przeszło 25 lat temu postulowali konieczność wprowadzenia zmian kryteriów diagnozy lekkich urazów czaszkowo-mózgowych.

$\mathrm{Na}$ tym tle bardzo ciekawa wydaje się praca duetu Rojas i Bennet (1995), w której przedstawiono, że wynik GNDS (General Neuropsychological Deficit Scale) umożliwia $\mathrm{z}$ dużą dokładnością określenie, który z pacjentów doświad- 
czył mTBI. GNDS (Reitan, Wolfson, 1988) jest wspólną miarą 42 zmiennych baterii Halsteada-Reitana (Kądzielawa, 1990), a w jego skład wchodzi między innymi Test łączenia punktów. Rojas i Benett (1995) dowiedli, że GNDS zweryfikował poprawnie aż 92\% spośród 25 osób, które doświadczyły mTBI w porównaniu do 25 osób grupy kontrolnej, dobranych pod względem wieku, płci oraz wykształcenia. Badacze zaznaczyli również, że przesiewowa wersja Testu Stroopa nie różnicowała tych dwóch grup.

Badania przeprowadzone przez Reitana i Wolfson (2000) wykazały, że pacjenci, którzy doświadczyli mTBI, osiągali w GDNS średni wynik 26,5 punktów, gdzie $61 \%$ z nich mieściło się w normie, a $39 \%$ uzyskiwało wynik wskazujący już na zaburzenia. Co bardzo istotne, wyniki osiągane przez pacjentów z diagnozą mTBI w ramach drugiej ze wspomnianych powyżej grup, wskazywały zdecydowanie na występowanie zaburzeń w zakresie badanych funkcji, w porównaniu do grupy kontrolnej, jednak ich profil był zdecydowanie bliższy profilowi właśnie osób zdrowych niż pacjentów z cięższymi urazami OUN.

W przedstawianej pracy wyniki grupy klinicznej nie różniły się istotnie od wyników grupy kontrolnej ani w części A, ani w części B. W kolejnych z dokonywanych pomiarów pacjenci osiągali wyniki o bardzo zbliżonych wartościach. Porównanie długości czasu wykonania części B do części A ujawniło zmianę wyników w czasie w grupach klinicznych. Czy uzasadnione byłoby zatem stwierdzenie, że w badanej grupie pacjentów, pomimo urazu, zostały zachowane lub też nie osłabione funkcje takie jak: zdolność skupienia uwagi, pamięć krótkotrwała, podstawowe zdolności wzrokowo-motoryczne, inhibicja bodźców konfliktowych i swoboda przechodzenia od jednego rodzaju bodźca (litera/cyfra/litera) do drugiego? Biorąc pod uwagę wcześniejsze dane dotyczące bardzo dużego indywidualnego zróżnicowania pacjentów po lekkim urazie czaszkowo-mózgowym i ponad $60 \%$ wyników w takiej grupie utrzymujących się w granicach normy, pozostaje mi stwierdzić, że w grupie badanych przeze mnie osób po doświadczonym mTBI wyniki Testu łączenia punktów nie wskazały na zaburzenia i być może pacjenci ci zaliczali się właśnie do tych przeszło $2 / 3$ przypadków. Jak widać, prawidłowe wyniki w zakresie testu TMT są bardziej niż prawdopodobne do uzyskania. Jednocześnie nie można stwierdzić, że są równoznaczne z całkowitym brakiem konsekwencji urazu.

Chciałbym również zauważyć, że Test łączenia punktów, nawet jeśli nie wskazał na istotne różnice między wynikami grupy klinicznej i kontrolnej, może stanowić doskonałe pole do obserwacji klinicznej pacjentów w sensie jakościowej analizy zachowania, którą omawiany projekt objął, lecz ze względu na 
ograniczenie objętości przedstawianych treści nie została ona ujęta w obecnym omówieniu. Podobnie zresztą jak kolejny z testów - Test Wieży Londyńskiej.

Podsumowując, można stwierdzić, że metodami w największym stopniu różnicującymi wyniki pacjentów po doświadczonym lekkim urazie czaszkowo-mózgowym w stosunku do grupy kontrolnej były: Test fluencji słów, test Powtarzanie cyfr $\mathrm{z}$ baterii testów Wechslera i testy TUS. Pewne zróżnicowanie wyników oddawały również: Test Stroopa oraz Symbole cyfr z baterii testów Wechslera.

Odnosząc się do celu pracy i na podstawie powyższych wyników, można stwierdzić, że u osób po lekkim urazie czaszkowo-mózgowym obserwuje się zaburzenia przede wszystkim w zakresie szybkości przetwarzania informacji, fluencji słownej, jak również wnioskuje pośrednio o obniżeniu poziomu funkcjonowania pewnych aspektów procesów pamięci operacyjnej i uwagi.

$\mathrm{W}$ związku z wynikami osiąganymi przez grupę kliniczną w testach ToL i TMT, czy w zakresie interpretacji przysłów, można wnioskować o braku zaburzeń w obrębie: kontroli impulsów, inicjacji działania, zdolności planowania i organizacji.

Główna hipoteza weryfikowana w omawianym projekcie dotyczyła dynamiki zmian funkcji wykonawczych u pacjentów po lekkich urazach czaszkowo-mózgowych okolicy czołowej. Zakładano, że wyniki badań neuropsychologicznych w ramach wykorzystanych metod wskazywać będą na stopniową poprawę funkcjonowania pacjentów w zakresie EF wraz z kolejnymi pomiarami w fazie ostrej i podostrej oraz powrotu do poziomu funkcjonowania sprzed urazu w około pół roku.

Otrzymany obraz okazał się dużo bardziej złożony. Wyniki prezentowanych w projekcie badań pozostają w zgodzie z danymi pochodzącymi z piśmiennictwa, które wskazują na obniżenie poziomu funkcjonowania w zakresie prędkości przetwarzania informacji, procesów uwagi i pamięci oraz niekiedy obniżonej fluencji werbalnej w okresie do około 1 tygodnia od doświadczonego lekkiego urazu czaszkowo-mózgowego (Cicerone, Levin, Malec, Stuss, Whyte, 2006; de Freitas Cardoso i in., 2019). Jednak wbrew oczekiwaniom, w przeprowadzonych badaniach, jeżeli już, to najniższe wyniki (w ramach wspomnianych wyżej procesów) towarzyszyły pomiarom wykonywanym nie wkrótce po urazie, a w 1 tydzień i 2 tygodnie później, to jest na przestrzeni około 7-14 dni, przy czym można domniemywać, że po upływie około pół roku powracały do normy.

Reasumując, można stwierdzić, że po lekkich urazach czaszkowo-mózgowych nie obserwuje się całościowego zaburzenia funkcjonowania w zakresie funkcji wykonawczych. Funkcjonowanie pacjentów ulega pogorszeniu 
$\mathrm{w}$ ramach wymienionych aspektów EF $\mathrm{w}$ okresie ostrym i podostrym i to wówczas można zaproponować im program ćwiczeń umożliwiający usprawnianie procesów pamięci, uwagi czy szybkości przetwarzania informacji. $\mathrm{Na}$ podstawie powyższych wyników badań wskazana wydaje się również refleksja nad proponowanym programem ustrukturalizowanej rehabilitacji neuropsychologicznej dla osób po doświadczonym mTBI, a w szczególności charakter zadań i aktywności w fazie podostrej.

\section{Biblografia}

Alvarez, J. A., Emory, E. (2006). Executive function and the frontal lobes: A metaanalytic review. Neuropsychological Review, 16, 17-42. https://doi.org/10.1007/ s11065-006-9002-x

Anderson, P. (2008). Towards a developmental model of executive function. W: V. Anderson, R. Jacobs, P. J. Anderson (red.), Executive functions and the frontal lobes. A life time perspective (s. 3-21). Nowy Jork-Londyn: Taylor \& Francis Group.

Barrat, A., Barthelemy, M., Pastor-Satorras, R., Vespignani, A. (2004). The architecture of complex weighted networks. Protocols of the National Academy of Sciences of the United States of America, 101(11), 3747-3752. https://doi.org/10.1073/pnas.0400087101

Bartels, C., Węgrzyn, M., Wiedl, A., Ackermann, V., Ehrenreich, H. (2010). Practice effects in healthy adults: A longitudinal study on frequent repetitive cognitive testing. BMC Neuroscience, 11, 118. https://doi.org/10.1186/1471-2202-11-118

Basso, M. R., Bornstein, R. A., Lang, J. M. (1999). Practice effects on commonly used measures of executive function across twelve months. Clinical Neuropsychologist, 13(3), 283-292. https://doi.org/10.1076/clin.13.3.283.1743

Basso, M. R., Candilis, P. J., Johnson, J., Ghormley, C., Combs, D. R., Ward, T. (2010). Capacity to make medical treatment decisions in multiple sclerosis: A potentially remediable deficit. Journal of Clinical and Experimental Neuropsychology, 32(10), 1050-1061. https://doi.org/10.1080/13803391003683062

Beglinger, L. J., Gayolos, B., Tangphao-Daniels, O., Duff, K., Kareken, D. A., Crawford, J., ..., Siemers, E. R. (2005). Practice effects and the use of alternate forms in serial neuropsychological testing. Archives of Clinical Neuropsychology, 20(4), 517-529. https://doi.org/10.1016/j.acn.2004.12.003

Berg, W. K., Byrd, D. L., McNamara, J. P., Case, K. (2010). Downstructuring the tower: Parameters and predictors of problem difficulty on the ToL task. Brain and Cognition, 72(3), 472-482. https://doi.org/10.1016/j.bandc.2010.01.002 
Bigler, E. D., Maxwell, W. L. (2012). Neuropathology of mild brain injury: Relationship to neuroimaging studies. Brain Imaging and Behaviour, 6(2), 108-136. https://doi. org/10.1007/s11682-011-9145-0

Bird, C. M., Papadopoulou, K., Ricciardelli, P., Rossor, M. N., Cipolotti, L. (2004). Monitoring cognitive changes: Psychometric properties of six cognitive tests. British Journal of Clinical Psychology, 43(2), 197-210. https://doi.org/10.1348/014466504323088051

Box, G. E. P., Cox, D. R. (1964). An analysis of transformations. Journal of the Royal Statistical Society. Series B (Methodology), 26(2), 211-252. https://doi.org/10.1111/j.2517-6161.1964.tb00553.x

Brzeziński, J., Gaul, M., Hornowska, E., Jaworowska, A., Machowski, A., Zakrzewska, M. (2004). Skala Inteligencji D. Wechslera dla Dorostych. Wersja Zrewidowana-Renormalizacja WAIS-R(PL). Podręcznik. Warszawa: Pracownia Testów Psychologicznych Polskiego Towarzystwa Psychologicznego.

Cantor, J., Ashman, T., Dams-O'Connor, K., Dijkers, M. P., Gordon, W., Spielman, L., ..., Oswald, J. (2013). Evaluation of the short-term executive plus intervention for executive dysfunction after traumatic brain injury: A randomized controlled trial with minimization. Archives of Physical Medicine and Rehabilitation, 95(1), 1-9. https://doi.org/10.1016/j.apmr.2013.08.005

Chaytor, N., Schitter-Edgecomb, M., Burr, R. (2006). Improving the ecological validity of executive functioning assessment. Archives of Clinical Neuropsychology, 21(3), 217-227. https://doi.org/10.1016/j.acn.2005.12.002

Cicerone, K., Levin, H., Malec, J., Stuss, D., Whyte, J. (2006). Cognitive rehabilitation interventions for executive function: Moving from bench to bedside in patients with traumatic brain injury. Journal of Cognitive Neuroscience, 18(7), 1212-1222. https://doi.org/10.1162/jocn.2006.18.7.1212

Ciechanowicz, A., Stańczak, J. (2006). Testy Uwagi i Spostrzegawczości TUS. Podręcznik. Warszawa: Pracownia Testów Psychologicznych.

Clawson, D. M. (2002). Practice specificity in the classic Stroop color-word task. Boulder: University of Colorado.

Cummings, J. L., Miller, B. L. (2007). Conceptual and clinical aspects of the frontal lobes. W: B. L. Miller, J. L. Cummings (red.), The human frontal lobes. Functions and disorders (s. 12-21). Nowy Jork-Londyn: The Guilford Press.

de Freitas Cardoso, M. G., Faleiro R. M., de Paula J. J., Kummer, A., Caramelli, P., Teixeira, A. L., ..., Miranda, A. S. (2019). Cognitive impairment following acute mild traumatic brain injury. Frontiers in Neurology, 10, 1-9. https:/doi.org/10.3389/ fneur.2019.00198 
Denckla, M. B. (1994). Measurement of executive function. W: G. R. Lyon (red.), Frames of reference for the assessment of learning disabilities: New views on measurement issues (s. 117-142). Baltimore: Paul H. Brookes Publishing Co.

Desrosiers, J. D., Bourbonnais, D., Corriveau, H., Gosselin, S., Bravo, G. (2005). Effectiveness of unilateral and symmetrical bilateral task training for arm during the subacute phase after stroke: A randomized controlled trial. Clinical Rehabilitation, 19(6), 581-593. https://doi.org/10.1191/0269215505cr896oa

Dikmen, S., Reitan, R. M., Temkin, N. R. (1983). Neuropsychological recovery in head injury. Archives of Neurology, 40(6), 333-338. https://doi.org/10.1001/archneur.1983.04050060033004

Eirud, C., Cradoch, R. C., Fletcher, S., Aulach, M., King-Kasas, B., Kuchl, P., Laconte, S. M. (2014). Neuroimaging after mild traumatic brain injury: Review and metaanalysis. Neuroimage: Clinical, 4, 283-294. https://doi.org/10.1016/j.nicl.2013.12.009

Ferguson, G. A., Takane, Y. (1999). Analiza statystyczna w psychologii i pedagogice. Warszawa: Wydawnictwo Naukowe PWN.

Field, R. D. (2011). Drugi mózg. Warszawa: Prószyński i S-ka.

Fisher, R. A., Yates, F. (1963). Statistical tables for biological, agricultural and medical research. Edynburg: Oliver and Boyd.

Gioia, G. A., Isquith, P. K., Guy, S. C. (2001). Assessment of executive functions in children with neurological impairment. W: R. Simeonsson, S. L. Rosenthal (red.), Psychological and developmental assessment: Children with disabilities and chronic conditions (s. 317-356). Nowy Jork: Guilford Press.

Giza, C. C., Hovda, D. A. (2001). The neurometabolic cascade of concussion. Journal of Athletic Training, 36(3), 228-235.

Gordon, W. A. (2013). Improving executive functions after traumatic brain injury (TBI): A clinical trial of the „Executive Plus” Program. NIH: US National Library of Medicine.

Gómez-de-Regil, L. (2020). Assessment of executive function in patients with traumatic brain injury with the Wisconsin Card-Sorting Test. Brain Sciences, 10(10), 699. https://doi.org/10.3390/brainsci10100699

Inverson, G. L. (2005). Outcome from mild traumatic brain injury. Current Opinions in Psychiatry, 18(3), 301-317. https://doi.org/10.1097/01.yco.0000165601.29047.ae

Jaworowska, A. (2002). Test Sortowania Kart z Wisconsin. Podręcznik. Warszawa: Pracownia Testów Psychologicznych Polskiego Towarzystwa Psychologicznego.

Johanson, B., Berglund, P., Ronnback, L. (2009). Mental fatigue and impaired information processing after mild and moderate traumatic brain injury. Brain Injury, 23(13-14), 1027-1040. https://doi.org/10.3109/02699050903421099 
Katayama, Y., Becker, D. P., Tamura, T., Hovda, D. A. (1990). Massive increases in extracellular potassium and the indiscriminate release of glutamate following concussive brain injury. Journal of Neurosurgery, 73(6), 889-900. Pobrane z: https:// thejns.org/view/journals/j-neurosurg/73/6/article-p889.xml

Kądzielawa, D. (red.). (1990). Bateria testów neuropsychologicznych Halsteada-Reitana. Warszawa: Pracownia Testów Psychologicznych.

Kennedy, M. R. T., Coelho, G., Turkstra, L., Ylvisaker, M., Moore Sohlberg, M., Yorkston K., ..., Kan, P.-F. (2008). Interventions for executive functions after traumatic brain injury: A systematic review, meta-analysis and clinical recommendations. Neuropsychological Rehabilitation, 18(3), 257-299. https://doi. org/10.1080/09602010701748644

Kordys, J., Ulatowska, H. K., Kądzielawa, D., Sadowska, M. (2001). Z badań nad przysłowiami: wstęp do neuroparemiologii. Pamiętnik Literacki: Czasopismo Kwartalne Poświęcone Historii i Krytyce Literatury Polskiej, 92(4), 135-162.

Kużdżał, A., Magoń, G. (2018). Rehabilitacja w urazach czaszkowo-mózgowych. Z praktyki gabinetu, 74, 71-80.

Landry-Roy, C., Bernier, A., Gravel, J., Beauchamp, M. H. (2018). Executive functions and their relation to sleep following mild traumatic brain injury in preschoolers. Journal of the International Neuropsychological Society. JINS, 24(8), 769-780. https://doi.org/10.1017/S1355617718000401

Lezak, M. D. (1995). Neuropsychological assessment. Nowy Jork: Oxford University Press. Lezak, M. D., Howieson, D. B., Bigler, E. D., Tranel, D. (2012). Neuropsychological assessment. Oxford: Oxford University Press.

López-Navarro, E. (2018). Contributions of executive functions components to affective and cognitive theory of mind in outpatients diagnosed with schizophrenia. Psychiatry Research, 269, 124-125. https://doi.org/10.1016/j.psychres.2018.08.018

Łuria, A. (1963). Restoration of function after brain injury. Nowy Jork: Pergamon Press. Łuria, A. (1973). The working brain. Nowy Jork: Basic Books.

Madjar, N., Chubarov, E., Zalsman, G., Weiser, M., Shoval, G. (2019). Social skills, executive functioning and social engagement. Schizophrenia Research. Cognition, 17, 100137. https://doi.org/10.1016/j.scog.2019.100137

Nakamura, T., Hillary, F. G., Biswal, B. B. (2009). Resting network plasticity following brain injury. PLOS ONE, 4(12), e8220. https://doi.org/10.1371/journal.pone.0008220

Novakovic-Agopian, T., Chen, A., Rome, S., Rossi, A., Abrams, G., D’Esposito, M., ..., Castelli, H. (2014). Assessment of subcomponents of executive functioning in ecologically valid settings: The goal processing scale. Journal of Head Trauma Rehabilitation, 29(2), 136-146. https://doi.org/10.1097/HTR.0b013e3182691b15 
Ozga, J. E., Povroznik, J. M., Engler-Chiurazzi, E. B., Vonder Haar, C. (2018). Executive (dys)function after traumatic brain injury: Special considerations for behavioral pharmacology. Behavioural Pharmacology, 29(7), 617-637. https://doi.org/10.1097/ FBP.0000000000000430

Peng, T.-I., Jou, M.-J. (2010). Oxidative stress caused by mitochondrial calcium overload. Annals of the New York Academy of Sciences, 1201, 183-188. https://doi. org/10.1111/j.1749-6632.2010.05634.x

Perry, R. E., Braren, S. H., Rincón-Cortés M., Brandes-Aitken, A. N., Chopra, D., Opendak, M., ..., Blair, C. (2019). Enhancing executive functions through social interactions: Causal evidence using a cross-species model. Frontiers in Psychology, 10, 2472. https://doi.org/10.3389/fpsyg.2019.02472

Prusiński, A. (2007). Neurologia praktyczna. Warszawa: PZWL.

R Core Team. (2018). R: A language and environment for statistical computing. Wiedeń: R Foundation for Statistical Computing. Pobrane z: http://www.R-project.org/

Reitan, R. M., Wolfson, D. (1986). Traumatic brain injury, t. 1. Pathophysiology and neuropsychological evaluation. Tucson: Neuropsychology Press.

Reitan, R. M., Wolfson, D. (1988). Traumatic brain injury, t. 2. Recovery and rehabilitation. Tucson: Neuropsychology Press.

Reitan, R. M., Wolfson, D. (2000). The neuropsychological similarities of mild and more severe head injury. Archives of Clinical Neuropsychology, 15(5), 433-442.

Roberts, R. J., Pennington, B. F. (1996). An interactive framework for examining prefrontal cognitive processes. Developmental Neuropsychology, 12(1), 105-126. https://doi.org/10.1080/87565649609540642

Rojas, D. C., Bennett, T. L. (1995). Single versus composite score discriminative validity with the Halstead-Reitan Battery and the Stroop Test in mild brain injury. Archives of Clinical Neuropsychology, 10(2), 101-110. https://doi.org/10.1016/08876177(94)E0038-Q

Ruesch, J. (1944). Intellectual impairment in head injuries. The American Journal of Psychiatry, 100(4), 480-496. https://doi.org/10.1176/ajp.100.4.480

Sacharczuk, M. (2005). Neurogeneza wieku dorosłego. Warszawa: Wydawnictwo Lekarskie PZWL.

Shallice, T. (1982). Specific impairments of planning. Philosophical Transactions of the Royal Society B, 298(1089), 199-209. https://doi.org/10.1098/rstb.1982.0082

Shallice, T. (1990). From neuropsychology to mental structure. Nowy Jork: Oxford University Press.

Stuss, D. T., Alexander, M. P. (2000). Executive functions and the frontal lobes: A conceptual view. Psychological Research, 63(3-4), 289-298. https://doi.org/10.1007/ s004269900007 
Takeuchi, H., Taki, Y., Sassa, Y., Hashizume, H., Sekiguchi, A., Fukushima, A., Kawashima, R. (2013). Brain structures associated with executive functions during everyday events in a non-clinical sample. Brain Structure \& Function, 218(4), 1017-1032. https://doi.org/10.1007/s00429-012-0444-z

Tsuchida, A., Fellows, L. K. (2013). Are case component processes of EF dissociate within the frontal lobes? Evidence from humans with focal prefrontal damage. Cortex, 49(7), 1790-1800. https://doi.org/10.1016/j.cortex.2012.10.014

Wheeler, S. (2014). Approaches to managing executive cognitive functioning impairment following TBI: A focus on facilitating community participation. W: F. Sadaka (red.), Traumatic brain injury. Pobrane z: https://www.intechopen.com/chapters/46062

Williams, D. H., Levin, H. S., Eisenberg, H. M. (1990). Mild head injury classification. Neurosurgery, 27, 422-428. https://doi.org/10.1097/00006123-199009000-00014

Wilson, B., Gracey, F., Evans, J., Bateman, A. (2009). Neuropsychological rehabilitation: Theory, models, therapy and outcome. Cambridge: Cambridge University Press. https://doi.org/10.1017/CBO9780511581083

Wilson, B., Winegardner, J., van Heugten, C., Ownsworth, T. (red.). (2017). Neuropsychological rehabilitation: The international handbook. Londyn-Nowy Jork: Routledge. https://doi.org/10.4324/9781315629537

Xiong, Y., Gu, Q., Peterson, P. L., Muizelaar, J. P., Lee, C. P. (1997). Mitochondrial dysfunction and calcium perturbation induced by traumatic brain injury. Journal of Neurotrauma, 14(1), 23-34. https://doi.org/10.1089/neu.1997.14.23

Zartman, A. L., Hilsabeck, R. C., Guarnaccia, C. A., Houtz, A. (2013). The pillbox test: An ecological measure of executive functioning and estimate of medication management activities. Archives of Clinical Neuropsychology, 28(4), 307-319. https:// doi.org/10.1093/arclin/act014

Zelazo, P. D., Qu, L., Müller, U. (2005). Hot and cool aspects of executive function: Relations in early development. W: W. Schneider, R. Schumann-Hengsteler, B. Sodian (red.), Young children's cognitive development: Interrelationships among executive functioning, working memory, verbal ability, and theory of mind (s. 71-93). Mahwah: Lawrence Erlbaum Associates Publishers. 
Ksymena PyL

AgNiesZKA E. ŁYŚ (iD https://orcid.org/0000-0001-8346-1862

KAMILLA BARGIEL-MATUSIEWICZ (iD) https://orcid.org/0000-0002-9467-2267

Wydział Psychologii, Uniwersytet Warszawski

\section{Predyktory mitów na temat zgwałceń w męskich środowiskach sportowych na podstawie badania przeprowadzonego wśród zawodowych piłkarzy \\ Predictors of rape myths in male sportsmen on the basis of a research of professional footballers}

Sposób cytowania: Pyl, K., Łyś, A. E., Bargiel-Matusiewicz, K. (2021). Predyktory mitów na temat zgwałceń w męskich środowiskach sportowych na podstawie badania przeprowadzonego wśród zawodowych piłkarzy. W: M. Huflejt-Łukasik, A. Pluta (red.), Mechanizmy psychologiczne i społeczne warunkujace formułowanie ocen oraz podejmowanie działań (s. 203-224). Warszawa: Wydawnictwo Liberi Libri. https:// doi.org/10.47943/lib.9788363487553.rozdzial10 


\section{Streszczenie}

Piłka nożna jest stereotypowo męskim sportem, który stosunkowo często kojarzony jest w mediach ze skandalami na tle seksualnym. W poniższym badaniu sprawdzono, jakie są predyktory akceptacji mitów na temat zgwałceń (rape myth acceptance, RMA) wśród zawodowych piłkarzy ( $N$ = 65). Najwięcej mężczyzn popierało mity powiązane z przekonaniem, że gwałt jest związany $\mathrm{z}$ niepohamowanym popędem seksualnym i w związku z tym jest niezależny od woli sprawcy. Ponadto akceptacja mitów na temat zgwałceń jest skorelowana dodatnio z identyfikacją z płcią męską, a ujemnie - $\mathrm{z}$ samooceną. Badani piłkarze bardziej obwiniali ofiarę-mężczyznę niż ofiarę-kobietę. Akceptacja mitów na temat zgwałceń nie okazała się natomiast istotnie powiązana $\mathrm{z}$ wiekiem, wykształceniem i wielkością miejscowości pochodzenia badanych piłkarzy.

Słowa kluczowe: mity na temat zgwałceń, samoocena, męskość, sport, piłka nożna

\section{Abstract}

Football is a stereotypically masculine sport which is relatively often associated with sex scandals by the media. In the present study we checked the predictors of rape myth acceptance (RMA) among professional football players $(N=65)$. Most of participants endorsed the myths related to the belief that rape is linked to the uncontrollable sexual drive and consequently it does not depend on the perpetrator's will. Moreover, RMA is correlated positively with identification with male gender and negatively - with self-esteem. Participant were more inclined to blame a male victim than a female one. RMA did not turn out to be significantly correlated with age, education and hometown size of the participants.

Keywords: rape myths, self-esteem, masculinity, sport, football 


\section{Sport jako czynnik kształtujący męskość tradycyjną}

Sport, w tym szczególnie dyscypliny kontaktowe, do których należy piłka nożna, jest jedną z wielu praktyk kulturowych, które we współczesnym świecie kształtują męską tożsamość. Futbol nawiązuje do archetypu męskości dominującej zarówno w sensie fizycznym, jak i psychicznym. Gra na boisku dwudziestu dwóch wysportowanych mężczyzn to z jednej strony pokaz szybkości, siły i agresji, z drugiej zaś umiejętności szybkiego podejmowania decyzji, odwagi, rywalizacji czy orientacji na sukces własny, ale też całej drużyny (Melosik, 2010). Warto w tym miejscu przywołać tezę Michaela Messnera, amerykańskiego socjologa sportu, który stwierdza, że „w trakcie rozwoju współczesnej płci kulturowej i seksualności sport odegrał bardzo ważną rolę w promowaniu konserwatywnej formy męskości - i jest to szczególnie typowe dla męskich sportów zespołowych" (Messner, 1992, za: Anderson, 2011, s. 730). W tym miejscu należy także przywołać słowa pewnego znanego badacza obszaru gender, Erica Andersona, którego zdaniem „dyscypliny zespołowe są miejscem, gdzie heteroseksualni mężczyźni walczą o dominację w kulturach Zachodu” (Anderson, 2011, s. 730).

Sposób, w jaki sport kształtuje i podtrzymuje męskość hegemonialną w kulturze zachodniej, obrazuje narracja tworzona przez media na temat futbolu. Dziubiński, Mazur i Organista (2018) przeanalizowali 156 artykułów z Gazety Wyborczej w roku 2014 oraz 212 artykułów z roku 2010, ukazujących się w czasie trwających mistrzostw świata w piłce nożnej. Autorami wszystkich materiałów prasowych byli mężczyźni. Przeprowadzona analiza wykazała częste posługiwanie się metaforami wojennymi do opisu meczu i zachowań piłkarzy. Piłkarze nazywani byli w materiałach prasowych „żołnierzami”, „herosami”, „wojownikami”, trenerzy natomiast byli dla mediów „wodzami”, którzy „obmyślają kampanie”. Metafory wojenne sprawiają, że piłkarze urastają do rangi bohaterów narodowych, którzy na boisku walczą o honor całego narodu. Oprócz porównań do herosów wojennych, piłkarze występują w narracji dziennikarskiej jako „bogowie” i „czarodzieje”, co ma sugerować ich nadprzyrodzone moce. Nie brakuje także narracji odnoszącej starcia piłkarzy do walki bokserów, a więc sportu kolizyjnego i nastawionego na brutalność zawodników. Autorzy analizy zwracają uwagę, że dużo miejsca w doniesieniach prasowych zajmuje opis życia prywatnego piłkarzy, szczególne dotyczący ich podbojów seksualnych. Media szeroko rozpisują się o sprawności seksualnej futbolistów (liczbie partnerek i kolejnych romansach), co podtrzymuje stereotyp 
o ich męskości, a także akcentuje heteroseksualność piłkarzy i jednocześnie deprecjonuje same kobiety. Zdaniem autorów analizy, z relacji medialnych przebija zaniepokojenie zachowaniami uznawanymi za nieprzystające do wzoru męskości (na przykład płacz piłkarza po przegranym meczu).

Socjologowie zwracają uwagę, że tzw. socjalizacja w męskość dominującą nastąpiła $\mathrm{w}$ wyniku przemian społecznych, $\mathrm{z}$ obawy przed feminizacją rzeczywistości społecznej i przed utratą stabilnej męskości (Kluczyńska, 2010). Jak pisze Kluczyńska (2010), nieobecność ojców w procesie wychowania dzieci spowodowała, że to kobiety samodzielnie musiały wychować przyszłych mężczyzn. W odpowiedzi na ten stan rzeczy w USA rozwinął się ruch skautingowy, gdzie dorastający chłopcy mieli przyswajać typowo męskie wzorce i patriarchalne wartości. Wiązało się to ze wzrostem znaczenia sportów kontaktowych, dzięki którym dorastający chłopiec miał wdrażać się w tryby kontroli społecznej i uczyć się szacunku wobec autorytetu. Reasumując, sport zaczął pełnić ważną funkcję wychowawczą, zaczęto postrzegać go jako naturalny element rozwoju młodego mężczyzny. Sport był miejscem, gdzie chłopcy dzięki współzawodnictwu i naciskowi na siłę fizyczną mieli wyrastać na "prawdziwych mężczyzn”. Kluczyńska (2010) przytacza badania wspomnianego już Messnera (2002, za: Kluczyńska, 2010), z których wynika, że sport stał się immanentną częścią rozwoju męskości. Sport nie jest już formą rozrywki w ramach spędzania wolnego czasu, lecz „gruntownym treningiem charakteru i moralności”. Zatem przynależąc do drużyny sportowej, np. piłki nożnej, chłopcy uczą się praktykować i przyjmować dominujące w kulturze rozumienie męskości.

\section{Samoocena a męskość}

Badania przeprowadzone przez Williamsa i Best (1990) w 30 krajach wykazały duże podobieństwo międzykulturowe wzorca męskości, przedstawiającego mężczyznę jako osobę stanowczą i agresywną. W większości kultur mężczyźni posiadają wyższą pozycję i status społeczny niż kobiety, z drugiej jednak strony mężczyźni muszą wciąż udowadniać swoją siłę i pozycję, co dobrze opisuje teoria zagrożonej męskości (Vandello, Bosson, 2013). Zgodnie z tą teorią, męskość nie jest cechą trwałą, daną raz na zawsze, lecz jest cechą ulotną i dlatego mężczyzna musi ją stale potwierdzać w życiu codziennym. W efekcie ciągła potrzeba udowadniania swojej męskości powoduje u mężczyzn permanentny 
niepokój i stres. Autorzy teorii podkreślają, że skłonność u mężczyzn do zachowań agresywnych i ryzykownych jest powodowana potrzebą udowadniania swojej męskości. Teoria głosi także, że mężczyźni unikają zachowań typowo kobiecych, ponieważ to mogłoby zachwiać ich męskością (Vandello, Bosson, 2013). Bosson, Vandello, Burnaford, Weaver i Wasti (2009) przeprowadzili eksperyment, $\mathrm{w}$ którym grupa eksperymentalna mężczyzn została poproszona o publiczne wykonanie czynności stereotypowo kobiecych, np. zaplatanie warkoczy manekinowi, podczas gdy grupa kontrolna wykonywała inne, neutralne zadanie. Następnie badani mogli wybrać sobie zadanie polegające na uderzaniu w worek treningowy bądź inne, niezwiązane $\mathrm{z}$ agresją fizyczną. Okazało się, że mężczyźni, którzy wykonywali kobiece czynności, częściej wybierali uderzanie w worek treningowy niż mężczyźni z grupy kontrolnej. Autorzy badania tłumaczą ten mechanizm chęcią kompensacji, związaną z nadszarpnięciem stereotypowo męskiego wizerunku. Badanie pokazuje zatem, że odstępstwo od ideału męskości może zachwiać samooceną.

Warto w tym miejscu wspomnieć jeszcze jedno badanie (Wong, Steinfeldt, LaFollette, Tsao, 2011), którzy przebadali zawodników futbolu amerykańskiego pod kątem stereotypowo kobiecych zachowań. Wyniki pokazały, że zawodnicy z wyższym poziomem samooceny byli bardziej skłonni zaakceptować niemęskie zachowania (w tym przypadku płacz po przegranych zawodach). Można zatem przypuszczać, że być może większą wyrozumiałość dla mężczyzny-ofiary przemocy seksualnej oraz niższą akceptację mitów na temat zgwałceń ogólnie będą posiadali piłkarze z wyższą samooceną. Hipoteza ta została zweryfikowana w badaniu własnym, opisanym w niniejszym rozdziale.

\section{Mity na temat zgwałceń}

Przemoc seksualna jest zjawiskiem postrzeganym przez pryzmat rozmaitych stereotypów, zwanych mitami na temat zgwałceń (rape myths). Według Burt $(1980$, s. 217) mity na temat zgwałcen to „stereotypowe, oparte na uprzedzeniach lub fałszywe przekonania na temat zgwałceń, ofiar zgwałceń i gwałcicieli”. Mity na temat zgwałceń nadal są poważnym problemem, o czym świadczy np. raport Komisji Europejskiej (European Commission, 2016). Wynika bowiem z niego, że aż 27\% Europejczyków uważa, że gwałt da się usprawiedliwić w co najmniej jednej z sytuacji wymienionych w badaniu, jak np. wpływ alkoholu lub narkotyków czy dobrowolne pójście do domu sprawcy. Ponadto aż $31 \%$ 
Europejczyków uważa, że bardziej prawdopodobny jest gwałt przez obcego sprawcę niż znajomego, podczas gdy statystyki zgwałceń (np. Smith i in., 2017) wskazują na to, że jest odwrotnie. Mity na temat zgwałceń, mierzone kwestionariuszami, są dodatnio skorelowane $\mathrm{z}$ obwinianiem ofiar, mierzonym za pomocą odpowiedzi na pytania dotyczące zaprezentowanych osobom badanym opisów przestępstw seksualnych (Hine, Murphy, 2019).

$\mathrm{W}$ wyjaśnianiu pochodzenia mitów na temat zgwałceń pomocna może być teoria usprawiedliwiania systemu (Jost, Banaji, 1994) mówiąca o tym, że stereotypy i uprzedzenia wynikają z potrzeby zachowania istniejącego porządku społecznego, bez względu na ewentualną krzywdę jednostki lub grupy. Dlatego, zgodnie z tą teorią, kobieta składająca na policji zeznania dotyczące gwałtu może być traktowana jako zagrożenie nie tylko dla gwałciciela, ale także dla systemu, usprawiedliwiającego niższy status społeczny kobiet. Chapleau i Oswald (2014) wykazały dodatnią korelację między akceptacją mitów na temat zgwałceń a usprawiedliwianiem systemu. Na akceptację mitów na temat zgwałceń jako formę usprawiedliwiania systemu mogą wskazywać też powiązania akceptacji mitów na temat zgwałceń z innymi postawami sprzyjającymi stereotypom i uprzedzeniom, jak prawicowy autorytaryzm (Giovannelli, Jackson, 2013; Hantzi, Lampridis, Tsantila, Bohner, 2015).

Inną zmienną, którą warto wziąć pod uwagę, szukając wyjaśnienia akceptacji mitów na temat zgwałceń, jest wiara w sprawiedliwy świat. Wiąże się ona z przekonaniem, że ludzie otrzymują to, na co zasłużyli. Badania wskazują na związek wiary $\mathrm{w}$ sprawiedliwy świat $\mathrm{z}$ niektórymi stereotypami i uprzedzeniami, jak np. negatywne postawy wobec osób chorych na AIDS (Furnham, Procter, 1992). Strömwall, Alfredsson, Landström (2013) wykazali, że wiara w sprawiedliwy świat jest dodatnio skorelowana z obwinianiem ofiar zgwałceń.

Warto również zwrócić uwagę na wyniki badania Bohnera i Lampridisa (2004), którzy wykazali, że u kobiet o niskim poziomie akceptacji mitów na temat zgwałceń perspektywa spotkania z kobietą, która doświadczyła przemocy seksualnej, wiąże się z obniżeniem samooceny, podczas, gdy u kobiet o wysokim poziomie akceptacji mitów na temat zgwałceń zaobserwowano przeciwny efekt. Wynik ten wskazuje na to, że mity na temat zgwałceń mogą pełnić u kobiet rolę ochronną - mogą dawać poczucie, że gwałt zdarza się tylko kobietom, które w jakiś sposób przyczyniły się do tego, a w związku $\mathrm{z}$ tym one same są bezpieczne. 
Mity na temat zgwałceń a płeć ofiary. Zgwałcenia na mężczyznach także są tematem rozmaitych mitów, np. że mężczyzna nie może zostać zgwałcony, że zgwałcony mężczyzna sam jest sobie winny, że doświadczenie gwałtu nie jest dla mężczyzny traumą, bądź że gwałceni są przede wszystkim mężczyźni homoseksualni (Melanson, 1998; Struckman-Johnson, Struckman-Johnson, 1992). Przekonanie, że mężczyzna nie może stać się ofiarą gwałtu, jest powielane nawet przez systemy prawne niektórych państw, jak Wielka Brytania czy Szwajcaria. Według kodeksów karnych tych krajów ofiarą gwałtu może paść jedynie kobieta (Penal Code [UK], 2008; Swiss Criminal Code, 1937/2018). Tymczasem według badania National Intimate Partner and Sexual Violence Survey (Smith i in., 2017), przeprowadzonego na reprezentatywnej próbie mieszkańców USA, 1,9\% mężczyzn w USA w jakimś momencie swojego życia doświadczyło zgwałcenia, a 5,9\% zostało zmuszonych do penetracji.

Sommer, Reynolds i Kehn (2015) wykazali też, że ofiara płci męskiej jest bardziej narażona na obwinianie niż ofiara płci żeńskiej. Można to wyjaśnić podstawowym błędem atrybucji - ludzie mają powszechną skłonność do wyjaśniania zachowania obserwowanych osób w kategoriach przyczyn wewnętrznych i stałych (np. cech charakteru) przy jednoczesnym niedocenianiu wpływów sytuacyjnych, zewnętrznych (Ross, 1977). Nie dziwią zatem stereotypowe opinie, że kobieta (słaba i delikatna) nie może być sprawczynią przemocy seksualnej, a mężczyzna (silny i odważny) nie może paść ofiarą gwałtu. W badaniu opisanym w niniejszym rozdziale chciałybyśmy sprawdzić, czy ten efekt będzie miał miejsce także wśród piłkarzy.

Mity na temat zgwałceń w środowiskach sportowców. Badania wskazują, że mężczyźni mają wyższy wskaźnik akceptacji mitów na temat zgwałceń niż kobiety (Burt, 1980; Chapleau, Oswald, 2013, 2014; Hantzi i in., 2015; Russell, Hand, 2017; Suarez, Gadalla, 2010; van der Bruggen, Grubb, 2014; Vance, Sutter, Perrin, Heesacker, 2015). Burt (1980) wykazała też, że akceptacja mitów na temat zgwałceń koreluje dodatnio $\mathrm{z}$ wiekiem, a ujemnie $-\mathrm{z}$ wykształceniem. Biorąc pod uwagę, że mieszkańcy miast mają znacznie wyższy poziom wykształcenia niż mieszkańcy wsi, o czym świadczą np. wyniki Narodowego Spisu Powszechnego w Polsce (Narodowy Spis Powszechny, 2011), można przypuszczać, że akceptacja mitów na temat zgwałceń będzie ujemnie skorelowana z wielkością miejscowości pochodzenia, co postanowiłyśmy zweryfikować w badaniu własnym. Lutz-Zois, Moler, Brown (2015) wykazali ponadto, że normy tradycyjnej męskości są dodatnio skorelowane $\mathrm{z}$ akceptacją mitów na 
temat zgwałceń. Można zatem przypuszczać, że silna identyfikacja z płcią męską jest związana $\mathrm{z}$ akceptacją mitów na temat zgwałceń, co zostanie sprawdzone $\mathrm{z}$ badaniu własnym, opisanym $w$ niniejszym rozdziale. Zapewne dlatego mity na temat zgwałceń są poważnym problemem $\mathrm{w}$ silnie zmaskulinizowanych środowiskach, takich jak popularne w USA bractwa studenckie (Bleecker, Murnen, 2005; Boeringer, 1999; Carroll, Rosenstein, Foubert, Clark, Korenman, 2016; Navarro, Tewksbury, 2017). Bleecker i Murnen (2005) wykazali też, że studenci, którzy należą do bractw, mają w pokojach więcej zdjęć degradujących kobiety niż pozostali studenci. Ponadto Voller i in. (2015) wykazali, że akceptacja mitów na temat zgwałceń na mężczyznach (male rape myth acceptance) u żołnierzy jest ujemnie skorelowana z poczuciem własnej skuteczności, także u mężczyzn, którzy doświadczyli przemocy seksualnej.

Mity na temat zgwałceń są problemem także w środowiskach sportowych. Badania (Boeringer, 1999; Navarro, Tewksbury, 2017; Young i in., 2016) pokazują, że wśród studentów płci męskiej studenci-sportowcy charakteryzują się wyższym poziomem akceptacji mitów na temat zgwałceń niż pozostali studenci. Co więcej, Young i in. (2016) wykazały, że studenci-sportowcy częściej deklarują dopuszczenie się w przeszłości przestępstwa na tle seksualnym niż pozostali studenci, zaś akceptacja mitów na temat zgwałceń pełni tu rolę mediatora. Z badania Sawyer, Thompson, Chicorelli (2002) wynika zaś, że sportowcy dyscyplin drużynowych bardziej powszechnie akceptują mity na temat zgwałceń niż sportowcy dyscyplin indywidualnych.

\section{MetOdA}

\section{Hipotezy}

Na podstawie opisanych wcześniej badań sformułowano następujące hipotezy: Hipoteza 1: Akceptacja mitów na temat zgwałceń wśród piłkarzy koreluje dodatnio z wiekiem (H1a), a ujemnie z poziomem wykształcenia (H1b) oraz wielkością miejscowości pochodzenia osoby badanej (H1c).

Hipoteza 2: Obwinianie ofiary jest dodatnio skorelowane $\mathrm{z}$ akceptacją mitów na temat zgwałceń.

Hipoteza 3: Obwinianie ofiary jest większe, jeśli ofiarą jest mężczyzna. 
Hipoteza 4: Akceptacja mitów na temat zgwałceń jest negatywnie powiązana $\mathrm{z}$ samooceną.

Hipoteza 5: Akceptacja mitów na temat zgwałceń jest dodatnio skorelowana $\mathrm{z}$ identyfikacją z płcią męską.

\section{Rejestr zmiennych}

W badaniu ujęto następujące zmienne objaśniające: (1) demograficzne: wiek, wykształcenie, miejsce pochodzenia; (2) dotyczące cech osobowościowych: samoocena i identyfikacja z płcią męską; (3) manipulowano płcią ofiary gwałtu.

W badaniu ujęto następujące zmienne objaśniane: (1) akceptacja mitów na temat zgwałceń (2) obwinianie ofiar zgwałceń.

\section{Próba i procedura}

W badaniu wzięło udział 65 zawodowych piłkarzy z trzech klubów piłkarskich w województwie mazowieckim w wieku 18-47 lat (średnia wieku: $M=23,88 ; S D=6,26)$. Prawie połowa badanych (45\%) miała wykształcenie średnie, $18,5 \%$ wyższe, $14 \%$ - podstawowe, a 1 osoba (1,5\%) - zawodowe. Co piąty badany $(21,5 \%)$ nie podał swojego wykształcenia. Rozkład miejsca pochodzenia był względnie wyrównany: 21 badanych pochodziło $\mathrm{z}$ małego miasta lub wsi (32\%), 20 badanych (31\%) ze średniego miasta (21-100 tys.), 7 (11\%) pochodziło z miasta $100-500$ tys., a $17(26 \%)$ z miasta powyżej 500 tysięcy mieszkańców.

Piłkarzom na wstępie powiedziano ogólnie, jakiego tematu dotyczy badanie i poproszono ich o wypełnienie kwestionariuszy metodą papier-ołówek. Badani wypełniali kwestionariusze przed treningiem, w szatni. Nikt nie odmówił udziału w badaniu.

\section{Materiały i narzędzia badawcze}

Akceptacja mitów na temat zgwałceń. Aby zbadać akceptacja mitów na temat zgwałceń, wykorzystano skróconą wersję polskiej adaptacji (Łyś, Bargiel-Matusiewicz, Krasuski, Studzińska, 2021) kwestionariusza Updated Illinois Rape 
Myth Acceptance Scale (McMahon, Farmer, 2011), składającą się z 14 pozycji na 5-stopniowej skali Likerta. Kwestionariusz zawiera cztery podskale: (1) „Sama się prosiła” - mity sugerujące, że ofiara jest winna gwałtu (przykładowa pozycja: "Jeśli dziewczyna zostanie zgwałcona kiedy jest pijana, to jest ona przynajmniej trochę odpowiedzialna za to, co się stało”), (2) „On nie chciał” mity sugerujące, że gwałt to rezultat niekontrolowanego popędu seksualnego mężczyzny (przykładowa pozycja: „Kiedy faceci gwałcą, to zazwyczaj jest to spowodowane ich silną żądzą seksu”), (3) „To nie był naprawdę gwałt” - mity sugerujące, że niektóre przypadki zmuszenia do współżycia nie są gwałtami (przykładowa pozycja: „Jeśli dziewczyna nie odpowiada na atak siłą fizyczną, nie można tak naprawdę mówić o gwałcie”) i (4) „Ona kłamała” - mity sugerujące, że fałszywe oskarżenia o zgwałcenia są czymś powszechnym (przykładowa pozycja: „Często dziewczyny, które twierdzą, że zostały zgwałcone, po prostu mają problemy emocjonalne"). Zgodność wewnętrzna wyniku ogólnego wynosi $\alpha=0,84$, zaś zgodność wewnętrzna poszczególnych skal w badanej próbie wynosi odpowiednio: $\alpha=0,77 ; \alpha=0,63 ; \alpha=0,36$ i $\alpha=0,90$. $Z$ powodu niskiej zgodności wewnętrznej skali „To nie był gwałt”, analizowano jedynie wynik ogólny, bez podziału na podskale.

Obwinianie ofiar zgwałceń. W celu zbadania poziomu obwiniania ofiar zgwałceń badanym zaprezentowano dwie sceny opisujące gwałt. W obydwu sytuacjach sprawcą był mężczyzna, jednak sytuacje różniły się płcią ofiary. Obie sytuacje stanowiły zapis autentycznych wydarzeń opisanych w mediach w ostatnich latach. Do każdej z dwóch scen badani otrzymali pięć twierdzeń dotyczących oceny odpowiedzialności ofiary i sprawcy (przykładowe twierdzenie: „Gdyby Monika była ostrożniejsza, nie znalazłaby się w takiej sytuacji"), do których osoby badane miały za zadanie ustosunkować się na 6-stopniowej skali Likerta. Zgodność wewnętrzna skali w badanej próbie wynosi $\alpha=0,85 \mathrm{w}$ przypadku ofiary-kobiety i $\alpha=0,73 \mathrm{w}$ przypadku ofiary-mężczyzny.

Samoocena. W celu zmierzenia poziomu samooceny piłkarzy wykorzystano Skalę samooceny SES (Rosenberg, 1965), zaadaptowaną przez Łagunę, Lachowicz-Tabaczek i Dzwonkowską (2007), mierzącą samoocenę jako stałą cechę. Narzędzie składa się z 10 twierdzeń na 4-stopniowej skali Likerta (przykładowe twierdzenie: „Uważam, że posiadam wiele pozytywnych cech”). Zgodność wewnętrzna skali w badanej próbie wynosi $\alpha=0,87$. 
Identyfikacja z płcią męską. W celu określenia poziomu identyfikacji z płcią męską wykorzystano Skale identyfikacji z grupa własną Camerona (2004), zaadaptowaną przez Bilewicza i Wójcika (2010). Skala składa się z 12 twierdzeń ocenianych na 5-stopniowej skali Likerta, dotyczących identyfikacji $\mathrm{z}$ grupą własną, $\mathrm{w}$ tym przypadku z mężczyznami. Kwestionariusz mierzy trzy czynniki: siłę więzi z grupą (przykładowe twierdzenie: „Mam wiele wspólnego z innymi mężczyznami”), centralność tożsamości (przykładowe twierdzenie: „Bycie mężczyzną to ważna część tego, kim jestem”) oraz afekt wobec grupy (przykładowe twierdzenie: „Ogólnie jestem zadowolony z bycia mężczyzną"). Zgodność wewnętrzna wyniku ogólnego wynosi $\alpha=0,70$, zaś zgodność wewnętrzna skal w badanej próbie wynosi odpowiednio: $\alpha=0,64$; $\alpha$ $=0,48$ i $\alpha=0,84$. Z powodu niskiej zgodności wewnętrznej skali Centralność, analizowano jedynie wynik ogólny, bez podziału na podskale.

Dane demograficzne. Do zebrania danych demograficznych (wiek, wykształcenie, wielkość miejscowości pochodzenia badanego) wykorzystano ankietę demograficzną własnego autorstwa.

\section{WYNIKI}

\section{Statystyki opisowe}

Tabela 1 przedstawia charakterystykę zmiennych ilościowych, statystyki opisowe i normalności rozkładu.

Tabela 1

Statystyki opisowe i wartości testu normalności rozkładu Shapiro-Wilka zmiennych ilościowych w badanej grupie piłkarzy

\begin{tabular}{lccccccccc}
\hline Skala & Min & Max & $\boldsymbol{M}$ & SD & Me & S-W & $\boldsymbol{p}$ & Skośność & Kurtoza \\
\hline Samoocena & 24,0 & 40,0 & 32,9 & 4,7 & 34,0 & 0,946 & 0,009 & $-0,28$ & $-0,98$ \\
Identyfikacja z płcią męską & 18,0 & 59,0 & 43,25 & 7,15 & 44,0 & 0,957 & 0,030 & $-0,71$ & 2,06 \\
Akceptacja mitów na temat zgwałceńn & 18,0 & 58,0 & 34,94 & 9,02 & 35,0 & 0,984 & 0,60 & 0,15 & $-0,26$ \\
Obwinianie ofiary-kobiety & 1,00 & 6,00 & 1,34 & 0,71 & 1,20 & 0,504 & 0,000 & 4,81 & 29,3 \\
Obwinianie ofiary-mężczyzny & 1,00 & 6,00 & 1,58 & 0,84 & 1,20 & 0,697 & 0,000 & 2,84 & 11,5 \\
\hline
\end{tabular}


Rozkład wszystkich zmiennych, poza akceptacją mitów na temat zgwałceń, odbiegał istotnie od rozkładu normalnego. Potwierdza to istotny wynik testu Shapiro-Wilka. Oznacza to, że w analizie statystycznej w celu weryfikacji hipotez należy zastosować testy nieparametryczne.

\section{Przekonania na temat zgwałceń w grupie badanych piłkarzy}

Osoby badane oceniały swój stosunek do mitów na temat zgwałceń na 5-stopniowej skali Likerta, gdzie 1 oznaczało zdecydowanie się nie zgadzam, 2 - raczej się nie zgadzam, 3 - trochę się zgadzam, a trochę się nie zgadzam, 4 - raczej się zgadzam, a 5 - zdecydowanie się nie zgadzam. W tabeli 2 odpowiedzi 1 i 2 umieszczono w kategorii nie zgadzam się, a odpowiedzi 4 i 5 $\mathrm{w}$ kategorii zgadzam się.

Tabela 2

Akceptacja mitów na temat zgwałcen wyrażana wśród piłkarzy

\begin{tabular}{|c|c|c|c|c|}
\hline Skala & Treść mitu & Nie zgadzam się & $\begin{array}{l}\text { Trochę się } \\
\text { zgadzam, a trochę } \\
\text { się nie zgadzam }\end{array}$ & Zgadzam się \\
\hline \multirow[t]{3}{*}{$\begin{array}{l}\text { "Sama się } \\
\text { prosiła" }\end{array}$} & $\begin{array}{l}\text { Jeśli dziewczyna zostanie zgwałcona kie- } \\
\text { dy jest pijana, to jest ona przynajmniej } \\
\text { trochę odpowiedzialna za to, co się stało. }\end{array}$ & $72,3 \%$ & $7,7 \%$ & $20 \%$ \\
\hline & $\begin{array}{l}\text { Kiedy dziewczyny idą na przyjęcia } \\
\text { ubrane w wyzywające ubrania, same } \\
\text { proszą się o problemy. }\end{array}$ & $67,7 \%$ & $21,5 \%$ & $10,8 \%$ \\
\hline & $\begin{array}{l}\text { Jeśli dziewczyna idzie do pokoju sama } \\
\text { z chłopakiem, kiedy są na przyjęciu, to } \\
\text { jest to jej wina, jeśli zostanie zgwałcona. }\end{array}$ & $78,5 \%$ & $15,4 \%$ & $6,2 \%$ \\
\hline \multirow[t]{3}{*}{$\begin{array}{l}\text { "On nie } \\
\text { chciał" }\end{array}$} & $\begin{array}{l}\text { Kiedy faceci gwałca, to zazwyczaj jest to } \\
\text { spowodowane ich silną żądzą seksu. }\end{array}$ & $29,2 \%$ & $23,1 \%$ & $47,7 \%$ \\
\hline & $\begin{array}{l}\text { Faceci zazwyczaj nie zamierzają zmu- } \\
\text { szać dziewczyny do seksu, ale czasami } \\
\text { nie mogą się pohamować seksualnie. }\end{array}$ & $40 \%$ & $36,9 \%$ & $23,1 \%$ \\
\hline & $\begin{array}{l}\text { Gwałt ma miejsce, kiedy popęd seksual- } \\
\text { ny mężzzyzny wymyka się spod kontroli. }\end{array}$ & $29,2 \%$ & $21,5 \%$ & $49,2 \%$ \\
\hline
\end{tabular}

Ciąg dalszy tabeli na następnej stronie 
Ciąg dalszy tabeli z poprzedniej strony

\begin{tabular}{|c|c|c|c|c|}
\hline Skala & Treść mitu & Nie zgadzam się & $\begin{array}{c}\text { Trochę się } \\
\text { zgadzam, a trochę } \\
\text { się nie zgadzam }\end{array}$ & Zgadzam się \\
\hline \multirow[t]{3}{*}{$\begin{array}{l}\text { "To nie był } \\
\text { naprawdę } \\
\text { gwałt" }\end{array}$} & $\begin{array}{l}\text { Nie powinno uznawać się za gwałt } \\
\text { zbliżenia, do którego doszło kiedy facet } \\
\text { był pijany i nie zdawał sobie sprawy } \\
\text { z tego, co robił. }\end{array}$ & $89,2 \%$ & $7,7 \%$ & $3,1 \%$ \\
\hline & $\begin{array}{l}\text { Jeśli dziewczyna nie odpowiada na atak } \\
\text { siłą fizyczną, nie można tak naprawdę } \\
\text { mówić o gwałcie. }\end{array}$ & $75,4 \%$ & $16,9 \%$ & $7,7 \%$ \\
\hline & $\begin{array}{l}\text { Jeśli oskarżony „gwałciciel” nie ma } \\
\text { broni, tak naprawdę nie można nazwać } \\
\text { tego gwałtem. }\end{array}$ & $90,8 \%$ & $1,5 \%$ & $7,7 \%$ \\
\hline \multirow[t]{5}{*}{$\begin{array}{l}\text { "Ona } \\
\text { kłamała" }\end{array}$} & $\begin{array}{l}\text { Często dziewczyny, które twierdzą, że } \\
\text { zostały zgwałcone, zgodziły się na seks, } \\
\text { ale później tego żałowały. }\end{array}$ & $20 \%$ & $43,1 \%$ & $35,4 \%$ \\
\hline & $\begin{array}{l}\text { Oskarżenia o gwałt są często używane } \\
\text { jako sposób na odegranie się na } \\
\text { facetach. }\end{array}$ & $21,5 \%$ & $35,4 \%$ & $43,1 \%$ \\
\hline & $\begin{array}{l}\text { Dziewczyny, które twierdzą, że zostały } \\
\text { zgwałcone, często prowokowały faceta, } \\
\text { a potem miały wyrzuty sumienia. }\end{array}$ & $42,3 \%$ & $36,2 \%$ & $21,5 \%$ \\
\hline & $\begin{array}{l}\text { Często dziewczyny, które twierdzą, } \\
\text { że zostały zgwałcone, po prostu mają } \\
\text { problemy emocjonalne. }\end{array}$ & $40 \%$ & $38,5 \%$ & $21,5 \%$ \\
\hline & $\begin{array}{l}\text { Dziewczyny, które zostaną przyłapane } \\
\text { na zdradzie, czasem twierdzą, że } \\
\text { zostały zgwałcone. }\end{array}$ & $32,3 \%$ & $32,3 \%$ & $35,4 \%$ \\
\hline
\end{tabular}

Jak widać, niektóre mity mają bardzo małe poparcie. Jednak prawie połowa piłkarzy zgodziła się z twierdzeniami, że „Kiedy faceci gwałcą, to zazwyczaj jest to spowodowane ich silną żądzą seksu” oraz "Gwałt ma miejsce, kiedy popęd seksualny mężczyzny wymyka się spod kontroli”. 


\section{Obwinianie ofiary a wiek, poziom wykształcenia i wielkość miejsca pochodzenia}

Hipotezę 1, zakładającą związek pomiędzy obwinianiem ofiary a wiekiem badanych piłkarzy, zweryfikowano przy pomocy analizy korelacji rho Spearmana. Związek pomiędzy obwinianiem ofiary a wykształceniem i wielkością miejsca pochodzenia sprawdzono przy pomocy korelacji dla danych porządkowych - korelacji tau Kendalla. Wyniki przedstawia tabela 3. Istotne wyniki zostały pogrubione.

Tabela 3

Korelacje akceptacji mitów na temat zgwakceń i obwiniania ofiary z wiekiem, wyksztakceniem i wielkościq miejsca pochodzenia badanych piłkarzy (rho Spearmana)

\begin{tabular}{lcccccc}
\hline \multirow{2}{*}{ Zmienne } & \multicolumn{2}{c}{$\begin{array}{c}\text { Akceptacja mitów } \\
\text { na temat zgwałceń }\end{array}$} & \multicolumn{2}{c}{$\begin{array}{c}\text { Obwinianie } \\
\text { ofiary kobiety }\end{array}$} & \multicolumn{2}{c}{$\begin{array}{c}\text { Obwinianie } \\
\text { ofiary mężczyzny }\end{array}$} \\
\cline { 2 - 8 } & rho & $\boldsymbol{p}$ & rho & $\boldsymbol{p}$ & rho & $\boldsymbol{p}$ \\
\hline Wiek & $\mathbf{- 0 , 2 5 5}$ & $\mathbf{0 , 0 2 0}$ & 0,042 & 0,741 & 0,107 & 0,400 \\
\hline Wykształcenie & tau & $\boldsymbol{p}$ & tau & $\boldsymbol{p}$ & tau & $\boldsymbol{p}$ \\
Miejsce pochodzenia & $\mathbf{- 0 , 3 0 0}$ & $\mathbf{0 , 0 0 4}$ & $-0,061$ & 0,307 & $-0,041$ & 0,366 \\
\hline
\end{tabular}

Adnotacja. Wyniki istotne statystycznie zostały pogrubione.

Akceptacja mitów na temat zgwałceń okazała się istotnie ujemnie powiązana $\mathrm{z}$ wiekiem $\mathrm{i}$ wykształceniem, nie okazała się zaś powiązana $\mathrm{z}$ wielkością miejsca pochodzenia badanych piłkarzy. Analiza nie wykazała natomiast istotnych korelacji pomiędzy obwinianiem ofiary (zarówno kobiety, jak i mężczyzny) a zmiennymi demograficznymi.

\section{Płeć ofiary a jej obwinianie za gwałt}

Hipotezę 2, zakładającą wyższe obwinianie o gwałt ofiary płci męskiej, zweryfikowano przy pomocy nieparametrycznego testu Wilcoxona. Wyniki przedstawia tabela 4. 
Tabela 4

Porównanie opinii badanych piłkarzy dotyczacych obwiniania ofiary za gwałt w zależności od jej płci

\begin{tabular}{ccccc}
\hline Obwinianie ofiary & $\boldsymbol{M}$ & SD & Test Wilcoxona & Istotność \\
\hline Kobiety & 1,35 & 0,71 & $Z=3,27$ & 0,001 \\
Mężzzyzny & 1,58 & 0,84 & & \\
\hline
\end{tabular}

Porównanie wykazało istotną różnicę. Kiedy ofiarą gwałtu był mężczyzna, był istotnie bardziej obwiniany za gwałt, niż gdy ofiarą była kobieta.

\section{Związek obwiniania ofiary z przekonaniami na temat gwałtu}

Weryfikację hipotezy 3, zakładającej pozytywny związek obwiniania ofiary $\mathrm{z}$ akceptacją mitów na temat gwałtów, przeprowadzono przy pomocy analizy korelacji rho Spearmana. Korelacje obwiniania ofiary z przekonaniami na temat gwałtów wśród badanych piłkarzy przedstawia tabela 5 .

Tabela 5

Korelacje obwiniania ofiary za gwałt w zależności od jej płci z akceptacja mitów na temat zgwałceń (rho Spearmana).

\begin{tabular}{lccccc}
\hline & \multicolumn{2}{c}{ Obwinianie ofiary kobiety } & \multicolumn{2}{c}{ Obwinianie ofiary mężczyzny } \\
\cline { 2 - 5 } & rho & $\boldsymbol{p}$ & rho & $\boldsymbol{p}$ \\
\hline Akceptacja mitów na temat zgwałceń & 0,136 & 0,076 & 0,063 & 0,248 \\
\hline
\end{tabular}

Analiza nie wykazała dodatniej korelacji między akceptacją mitów na temat zgwałceń a obwinianiem ofiary. W przypadku powiązania między akceptacją mitów na temat zgwałceń a obwinianiem ofiary-kobiety możemy mówić jedynie o tendencji w kierunku istotności statystycznej $(p<0,10)$.

\section{Postawa wobec gwałtu a samoocena i identyfikacja z płcią męską}

Hipotezy 4 i 5, dotyczące związków akceptacji mitów na temat zgwałceń z samooceną i identyfikacją z płcią męską, zweryfikowano przy pomocy analizy korelacji rho Spearmana. Wyniki analizy korelacji przedstawia tabela 6 . 
Tabela 6

Korelacje akceptacji mitów na temat zgwakceń i obwiniania ofiar zgwakceń z samoocenq i identyfikacja z ptciq męskq (rho Spearmana)

\begin{tabular}{lccccccc}
\hline \multirow{2}{*}{ Zmienna } & \multicolumn{2}{c}{$\begin{array}{c}\text { Akceptacja mitów } \\
\text { na temat zgwałceń }\end{array}$} & \multicolumn{2}{c}{$\begin{array}{c}\text { Obwinianie } \\
\text { ofiary-kobiety }\end{array}$} & \multicolumn{2}{c}{$\begin{array}{c}\text { Obwinianie } \\
\text { ofiary-mężczyzny }\end{array}$} \\
\cline { 2 - 8 } & rho & $\boldsymbol{p}$ & rho & $\boldsymbol{p}$ & rho & $\boldsymbol{p}$ \\
\hline Samoocena & $\mathbf{- 0 , 2 4 6}$ & $\mathbf{0 , 0 2 5}$ & $-0,198$ & 0,058 & $-0,073$ & 0,284 \\
Identyfikacja z płcią męską & 0,013 & 0,461 & $\mathbf{- 0 , 2 2 0}$ & $\mathbf{0 , 0 4 4}$ & $\mathbf{- 0 , 2 2 3}$ & $\mathbf{0 , 0 4 2}$ \\
\hline
\end{tabular}

Adnotacja. Wyniki istotne statystycznie zostały pogrubione.

Analiza wykazała kilka istotnych korelacji. Samoocena korelowała istotnie ujemnie umiarkowanie $\mathrm{z}$ akceptacją mitów na temat zgwałceń. Im wyższa samoocena, tym mniejsze nasilenie tego przekonania. Nie wykazano natomiast istotnej korelacji identyfikacji z płcią męską z akceptacją mitów na temat zgwałceń, zaś korelacja identyfikacji z płcią męską z obwinianiem ofiar okazała się ujemna.

\section{Dyskusja}

Badanie wykazało, że akceptacja mitów na temat zgwałceń jest wśród piłkarzy zróżnicowana. Największa liczba badanych piłkarzy, bo prawie połowa, popierała mity związane z gwałtem jako rezultatem niepohamowanego popędu seksualnego „Gwałt ma miejsce, kiedy popęd seksualny mężczyzny wymyka się spod kontroli” $\mathrm{i}$ „Kiedy faceci gwałcą, to zazwyczaj jest to spowodowane ich silną żądzą seksu". Wysokim poparciem (43\%) cieszył się także jeden z mitów przedstawiających fałszywe oskarżenia o gwałt jako coś nagminnego: „Oskarżenia o gwałt są często używane jako sposób na odegranie się na facetach". Podobny wynik uzyskali Navarro i Tewksbury (2017), którzy przebadali studentów jednego $\mathrm{z}$ amerykańskich uniwersytetów, uprawiających zawodowo sport. W przypadku powyższej grupy badawczej wyniki pokazały, że podobnie jak w przypadku grupy badawczej piłkarzy w poniższym badaniu, tamtejsi sportowcy popierali mit na temat zgwałceń związany z przeszacowaniem liczby fałszywych oskarżeń.

Badanie nie potwierdziło hipotezy 1. Inaczej niż zakładano, akceptacja mitów na temat zgwałceń okazała się istotnie ujemnie powiązana $\mathrm{z}$ wiekiem i wykształceniem, nie okazała się zaś powiązana z wielkością miejsca po- 
chodzenia badanych piłkarzy. Otrzymane wyniki nie są spójne z wynikami podawanymi przez Burt (1980), które mówią, że rape myth acceptance koreluje dodatnio $\mathrm{z}$ wiekiem. Należy tu wziąć pod uwagę, że sportowcy z zasady są "młodą" grupą wiekową (w poniższej grupie badawczej $M_{\text {wiek }}=23,88$ ), dlatego aby wyciągnąć wiarygodne wnioski na temat zależności między akceptacją mitów na temat zgwałceń a wiekiem, należałoby przeprowadzić badanie na reprezentatywnej próbie. W przypadku wykształcenia badanie wskazuje, że im wyższe wykształcenie, tym mniejsza akceptacja mitów na temat zgwałceń, co jest zbieżne z wynikami uzyskanymi przez Burt (1980). Warto jednak mieć na uwadze, że ponad $20 \%$ badanych piłkarzy nie podało swojego wykształcenia. Nie potwierdziła się natomiast hipoteza dotycząca zależności między akceptacją mitów na temat zgwałceń a wielkością miejscowości pochodzenia. Być może wynika to ze zbyt małej próby.

Potwierdziła się natomiast hipoteza 2, dotycząca różnicy w obwinianiu za gwałt ofiary w zależności od jej płci. Zgodnie z założeniem badani piłkarze istotnie bardziej obwiniali ofiarę-mężczyznę, niż ofiarę-kobietę. Otrzymany wynik można wytłumaczyć teorią zagrożonej męskości, która mówi, że mężczyźni nie akceptują niemęskich zachowań, bo jest to niezgodne ze stereotypową męskością. W tym wypadku założono, że niemęskie zachowanie to takie, gdy mężczyzna pada ofiarą zgwałcenia. Zgodnie z teorią zatem, badani uznali takie zachowanie za niemęskie i obwiniali mężczyznę, który został zgwałcony.

Hipoteza 3 nie została potwierdzona. Akceptacja mitów na temat zgwałceń wprawdzie korelowała dodatnio $\mathrm{z}$ obwinianiem ofiary-kobiety, jednak wynik ten był jedynie na poziomie tendencji $(p=0,076)$. Być może wynika to ze zbyt małej próby. Badanie potwierdziło hipotezę 4 . Wystąpiła ujemna korelacja samooceny z akceptacją mitów na temat zgwałceń. Zatem należy tu wnioskować o tym, że mężczyźni z niskim poziomem samooceny kierują się stereotypowym myśleniem przy ocenianiu gwałtu. Hipoteza 5 nie została potwierdzona - nie było istotnej korelacji identyfikacji z płcią męską z akceptacją mitów na temat zgwałceń, zaś w przypadku korelacji identyfikacji z płcią męską z obwinianiem ofiar zależność okazała się odwrotna niż przewidywano.

Podsumowując powyższe wyniki, należy zwrócić uwagę, że zarówno w badaniach amerykańskich, jak i w poniższym badaniu, potwierdza się funkcjonowanie mitu „ofiara kłamała”. Podobne analogie funkcjonują w przypadku realnych oskarżeń o gwałt, o których słyszymy na co dzień. Mowa tu przede wszystkim o doniesieniach z mediów na temat osób publicznych oskarżonych o gwałt (w tym piłkarzy). Zazwyczaj osoba oskarżona broni się, zarzucając 
ofierze oszczerstwa i pomówienia. Wydaje się więc, że mit „ofiara kłamała” jest najbardziej powszechnym z mitów dotyczących przemocy seksualnej. Ujemna korelacja akceptacji mitów na temat zgwałceń z samooceną sugeruje, że akceptacja mitów na temat zgwałceń może pełnić rolę mechanizmu obronnego u mężczyzn mających niską samoocenę.

\section{Ograniczenia badania i przyszłe kierunki badań}

Powyższe badanie ma z pewnością duże ograniczenia (przede wszystkim niezbyt liczna grupa badawcza i brak porównania piłkarzy z inną grupą społeczną lub wiekową), dlatego wydaje się, że rozszerzenie badań na temat akceptacji mitów na temat zgwałceń jest wskazane i może przynieść ciekawe wyniki. Innym ograniczeniem badania jest fakt, że jest ono korelacyjne. Aby wyciągnąć wnioski na temat zależności przyczynowo-skutkowych, należałoby przeprowadzić badania eksperymentalne, $w$ których manipulowano by badanymi zmiennymi - samooceną oraz identyfikacją z płcią męską.

Warto byłoby także sprawdzić, skąd się wzięła ujemna korelacja między identyfikacją z płcią męską a obwinianiem ofiar zgwałceń. Ten wynik sugeruje, że wysoki wskaźnik identyfikacji z płcią męską sam w sobie nie musi być dysfunkcyjny. Warto byłoby sprawdzić powiązania między akceptacją mitów na temat zgwałceń i obwinianiem ofiar zgwałceń a innymi zmiennymi związanymi z męskością, jak np. konflikt ról płciowych (O’Neil, 2014) czy postrzeganie męskości jako czegoś nietrwałego, co trzeba na bieżąco udowadniać (O’Connor, Ford, Banos, 2017).

Ponadto warto mieć na uwadze, że większość badań akceptacji mitów na temat zgwałceń jest prowadzona na próbach amerykańskich. Zjawisko mitów na temat przemocy seksualnej nie jest obszarem dobrze zbadanym na gruncie polskim, więc dalsze badania wydają się tu niezbędne.

\section{BibLIOGRAFIA}

Anderson, E. (2011). Inclusive masculinities of university soccer players in the American Midwest. Gender and Education, 23(6), 729-744. https://doi.org/10.1080/09 540253.2010.528377 
Bilewicz, M., Wójcik, A. (2010). Does identification predict community involvement? Exploring consequences of social identification among the Jewish minority in Poland. Journal of Community \& Applied Social Psychology, 20, 72-79. https:// doi.org/10.1002/casp.1012

Bleecker, E. T., Murnen, S. K. (2005). Fraternity membership, the display of degrading sexual images of women, and rape myth acceptance. Sex Roles, 53, 487-493. https://doi.org/10.1007/s11199-005-7136-6

Boeringer, S. B. (1999). Associations of rape-supportive attitudes with fraternal and athletic participation. Violence Against Women, 5(1), 81-90. https:/doi. org/10.1177/10778019922181167

Bohner, G., Lampridis, E. (2004). Expecting to meet a rape victim affects women's self-esteem: The moderating role of rape myth acceptance. Group Processes \& Intergroup Relations, 7(1), 77-87. https://doi.org/10.1177/1368430204039974

Bosson, J. K., Vandello, J. A., Burnaford, R., Weaver, J., Wasti, A. (2009). Precarious manhood and displays of physical aggression. Personality and Social Psychology Bulletin, 35, 623-634. https://doi.org/10.1177/0146167208331161

Burt, M. R. (1980). Cultural myths and supports for rape. Journal of Personality and Social Psychology, 38(2), 217-230. https://doi.org/10.1037/0022-3514.38.2.217

Cameron, J. E. (2004). A three factor model of social identity. Self and Identity, 3, 239-262. https://doi.org/10.1080/13576500444000047

Carroll, M. H., Rosenstein, J. E., Foubert, J. D., Clark, M. D., Korenman, L. M. (2016). Rape myth acceptance: A comparison of military service academy and civilian fraternity and sorority students. Military Psychology, 28(5), 306-317. https://doi. org/10.1037/mil0000113

Chapleau, K. M., Oswald, D. L. (2013). Status, threat, and stereotypes: Understanding the function of RMA. Social Justice Research, 26(1), 18-41. https://doi.org/10.1007/ s11211-013-0177-z

Chapleau, K. M., Oswald, D. L. (2014). A system justification view of sexual violence: Legitimizing gender inequality and reduced moral outrage are connected to greater rape myth acceptance. Journal of Trauma \& Dissociation, 15(2), 204-218. https:// doi.org/10.1080/15299732.2014.867573

Dziubiński, Z., Mazur, Z., Organista, N. (2018). Konstruowanie kobiecości i męskości w sporcie na przykładzie języka sportowych przekazów prasowych w „Gazecie Wyborczej”. Studia Socjologiczne, 1(228), 195-218.

European Commission. (2016). Special Eurobarometer 449 - November 2016 „Gender-based violence”. Pobrane z: http://www.familyviolence.gov.cy/upload/20161212/1481532099-11419.pdf 
Furnham, A., Procter, E. (1992). Sphere-specific just world beliefs and attitudes to AIDS. Human Relations, 45(3), 265-280. https://doi.org/10.1177/001872679204500303

Giovannelli, T. S., Jackson, L. (2013). Sexual violence perceptions among Christian college students. Mental Health, Religion \& Culture, 16(3), 254-272. https://doi. org/10.1080/13674676.2012.657618

Hantzi, A., Lampridis, E., Tsantila, K., Bohner, G. (2015). Validation of the Greek Acceptance of Modern Myths about Sexual Aggression (AMMSA) scale: Examining its relationships with sexist and conservative political beliefs. International Journal of Conflict and Violence, 9(1), 122-133. https://doi.org/10.4119/ijcv-3072

Hine, B., Murphy, A. (2019). The influence of 'High' vs. 'Low' rape myth acceptance on police officers' judgements of victim and perpetrator responsibility, and rape authenticity. Journal of Criminal Justice, 60, 100-107. https://doi.org/10.1016/j. jcrimjus.2018.08.001

Jost, J. T., Banaji, M. R. (1994). The role of stereotyping in system justification and the production of false consciousness. British Journal of Social Psychology, 33(1), 1-27. https://doi.org/10.1111/j.2044-8309.1994.tb01008.x

Kluczyńska, U. (2010), Sport jako obszar konstruowania tożsamości mężczyzn. Znaczenia wpisane w sport i możliwości ich definiowania. W: M. Dąbrowska, A. Radomski (red.), Męskość jako kategoria kulturowa. Praktyki męskości (s. 86-99). Lublin: Wydawnictwo Wiedza i Edukacja.

Lutz-Zois, C. J., Moler, K. A., Brown, M. J. (2015). Mechanisms for the relationship between traditional masculine ideologies and rape myth acceptance among college men. Journal of Aggression, Maltreatment \& Trauma, 24(1), 84-101. https://doi.org/10.1080/10926771.2015.996311

Łaguna, M., Lachowicz-Tabaczek, K., Dzwonkowska, I. (2007). Skala samooceny SES Morrisa Rosenberga - polska adaptacja metody. Psychologia Społeczna, 2 02(04), 164-176.

Łyś, A. E., Bargiel-Matusiewicz, K., Krasuski, T., Studzińska, A. (2021). Psychometric properties of the polish updated Illinois rape myth acceptance scale. Current Psychology. https://doi.org/10.1007/s12144-020-01249-3

McMahon, S., Farmer, G. L. (2011). An updated measure for assessing subtle rape myths. Social Work Research, 35(2), 71-81. https://doi.org/10.1093/swr/35.2.71

Melanson, P. K. (1998). Belief in male rape myths: A test of two competing theories (Niepublikowana praca doktorska). Queen's University. Kingston.

Melosik, Z. (2015). Społeczno-kulturowe konstrukcje piłki nożnej: męskość, kolektywna tożsamość i japonizacja. Studia Edukacyjne, 37, 313-326.

Narodowy Spis Powszechny. (2011). Obszary wiejskie. Olsztyn: Urząd Statystyczny w Olsztynie. 
Navarro, J. C., Tewksbury, R. (2017). National comparisons of rape myth acceptance predictors between nonathletes and athletes from multi-institutional settings. Sexual Abuse, 31(5), 543-559. https://doi.org/10.1177/1079063217732790

O'Connor, E., Ford, T., Banos, N. (2017). Restoring threatened masculinity: The appeal of sexist and anti-gay humor. Sex Roles, 77, 567-580. https://doi.org/10.1007/ s11199-017-0761-Z

O’Neil, J. (2014). Men's gender role conflict: Psychological costs, consequences, and an agenda for Change. Waszyngton: American Psychological Association.

Penal Code [UK]. (2008). Article 117. Pobrane z: http://agc.gov.ms/wp-content/uploads/2010/02/penal_code.pdf (dostęp: 23.11.2021 r.).

Rosenberg, M. (1965). Society and adolescent self-image. Nowy Jork: Princeton University Press.

Ross, L. (1977). The intuitive psychologist and his shortcomings: Distortions in the attribution process. Advances in Experimental Social Psychology, 10, 173-220. https://doi.org/10.1016/S0065-2601(08)60357-3

Russell, K. J., Hand, C. J. (2017). Rape myth acceptance, victim blame attribution and just world beliefs: A rapid evidence assessment. Aggression and Violent Behavior, 37, 153-160. https://doi.org/10.1016/j.avb.2017.10.008

Sawyer, R. G., Thompson, E. E., Chicorelli, A. M. (2002). Rape myth acceptance among intercollegiate student athletes: A preliminary examination. American Journal of Health Studies, 18(1), 19-25.

Smith, S. G., Chen, J., Basile, K. C., Gilbert, L. K., Merrick, M. T., Patel, N., ..., Jain, A. (2017). The National Intimate Partner and Sexual Violence Survey (NISVS): 2010-2012 State Report. Atlanta: National Center for Injury Prevention and Control, Centers for Disease Control and Prevention.

Sommer, S., Reynolds, J., Kehn, A. (2015). Mock juror perceptions of rape victims. Journal of Interpersonal Violence, 31(17), 1-20. https://doi.org/10.1177/08862605 15581907.2012.02044.x

Strömwall, L. A., Alfredsson, H., Landström, S. (2013). Blame attributions and rape: Effects of belief in a just world and relationship level. Legal and Criminological Psychology, 18, 254-261. https://doi.org/10.1111/j.2044-8333

Struckman-Johnson, C., Struckman-Johnson, D. (1992). Acceptance of male rape myths among college men and women. Sex Roles, 27(3/4), 85-100. https://doi. org/10.1007/BF00290011

Suarez, E., Gadalla, T. M. (2010). Stop blaming the victim: A meta-analysis on rape myths. Journal of Interpersonal Violence, 25(11), 2010-2035. https://doi. org/10.1177/0886260509354503 
Swiss Criminal Code. (1937/2018). Article 190. Pobrane z: https://fedlex.data.admin.ch/ filestore/fedlex.data.admin.ch/eli/cc/54/757_781_799/20200701/en/pdf-a/fedlex-data-admin-ch-eli-cc-54-757_781_799-20200701-en-pdf-a.pdf (dostęp: 23.11.2021 r.). van der Bruggen, M., Grubb, A. R. (2014). A review of the literature relating to rape victim blaming: An analysis of the impact of observer and victim characteristics on attribution of blame in rape cases. Aggression and Violent Behavior, 19(5), 523-531. https://doi.org/10.1016/j.avb.2014.07.008

Vance, K., Sutter, M., Perrin, P. B., Heesacker, M. (2015). The media's sexual objectification of women, rape myth acceptance, and interpersonal violence. Journal of Aggression, Maltreatment \& Trauma, 24, 569-587.

Vandello, J. A., Bosson, J. K. (2013). Hard won and easily lost: A review and synthesis of theory and research on precarious manhood. Psychology of Men \& Masculinity, 14(2), 101-113. https://doi.org/10.1037/a0029826

Voller, E., Polusny, M. A., Noorbaloochi, S., Street, A., Grill, J., Murdoch, M. (2015). Self-efficacy, male rape myth acceptance, and devaluation of emotions in sexual trauma sequelae: Findings from a sample of male veterans. Psychological Services, 12(4), 420-427. https://doi.org/10.1037/ser0000046

Williams, J. E., Best, D. L. (1990). Measuring sex stereotypes: A multination study. Newbury Park: Sage.

Wong, Y. J., Steinfeldt, J. A., LaFollette, J. R., Tsao, S.-C. (2011). Men's tears: Football players' evaluations of crying behavior. Psychology of Men \& Masculinity, 12(4), 297-310. https://doi.org/10.1037/a0020576

Young, B.-R., Desmarais, S. L., Baldwin, J. A., Chandler, R. (2017). Sexual coercion practices among undergraduate male recreational athletes, intercollegiate athletes, and non-athletes. Violence Against Women, 23(7), 795-812. https://doi. org/10.1177/1077801216651339 
Książka jest bardzo ciekawym zbiorem artykułów pokazującym osiągnięcia naukowców w zakresie rozwoju teorii i badań nad problemami w obrębie psychologii poznawczej, psychologii społecznej, psychologii emocji, czy psychologii klinicznej. Stanowi materiał, który poszerza wiedzę czytelnika o nowe treści, nowe wątki, nowe podejścia do licznych zagadnień, a także pokazuje nowe sposoby myślenia o problemach i ich poznawaniu. Może też pełnić rolę stymulującą dla przyszłych badaczy oraz prowokować do refleksji i krytycznego spojrzenia na zasoby dotychczas zgromadzonej wiedzy. Może także ukierunkować obserwację otaczającej rzeczywistości oraz inspirować pomysły na praktyczny sens prowadzonych badań. Należy dodać, że książka z pewnością zainteresuje zarówno psychologów-badaczy, jak i studentów psychologii, a wybrane rozdziały - psychologów-praktyków.

dr hab. Ludwika Wojciechowska, prof. UZ

Kolejną monografię z serii Psychological Currents - Theory and Research należy przyjąć z zadowoleniem ze względu na rozwijanie i kontynuowanie rozważań nad mechanizmami ludzkiej aktywności w paradygmacie regulacyjnej teorii zachowania. (...) Jestem przekonany, że książka znajdzie licznych czytelników, stanowi praktyczny wkład do teorii regulacji i może być wzorem do tworzenia projektów badawczych. To chwalebne, że staramy się wnosić kolejne dane do rozumienia zachowania nie tyle uwarunkowania deterministyczne, a spełniające funkcje regulacyjne w sensie przywracania równowagi wewnętrznej i zewnętrznej organizmu, a także generowania zachowań transgresyjnych.

prof. dr hab. Roman Ossowski

www.LiberiLibri.pl

ISBN: 978-83-63487-55-3 